UNIVERSIDADE DE SÃO PAULO

FACULDADE DE FILOSOFIA, LETRAS E CIÊNCIAS HUMANAS

MAIT BERTOLLO

\title{
A capilarização das redes de informação no território brasileiro pelo smartphone
}

[Versão corrigida] 
MAIT BERTOLLO

\section{A capilarização das redes de informação no território brasileiro pelo smartphone}

[Versão corrigida]

Tese apresentada ao Programa de Pós-Graduação em Geografia Humana do Departamento de Geografia da Faculdade de Filosofia, Letras e Ciências Humanas da Universidade de São Paulo para a obtenção do título de Doutora.

Área de concentração: Geografia Humana

Orientador: Prof. Dr. Ricardo Mendes Antas Jr. 
Autorizo a reprodução e divulgação total ou parcial deste trabalho, por qualquer meio convencional ou eletrônico, para fins de estudo e pesquisa, desde que citada a fonte.

Catalogação da publicação

Serviço de Biblioteca e Documentação

Faculdade de Filosofia, Letras e Ciências Humanas da Universidade de São Paulo.

B536c

Bertollo, Mait Bertollo

A capilarização das redes de informação no território brasileiro pelo smartphone / Mait Bertollo Bertollo ; orientador Ricardo Mendes Antas Jr. Antas Jr. . - São Paulo, 2019.

$241 \mathrm{f}$.

Tese (Doutorado) - Faculdade de Filosofia, Letras e Ciências Humanas da Universidade de São Paulo. Departamento de Geografia. Área de concentração: Geografia Humana.

1. Capilarização da informação. 2. Smartphone. 3. Território. 4. Internet. 5. WhatsApp. I. Antas Jr. , Ricardo Mendes Antas Jr., orient. II Título. 


\title{
ENTREGA DO EXEMPLAR CORRIGIDO DA DISSERTAÇÃO/TESE
}

\section{Termo de Ciência e Concordância do (a) orientador (a)}

\author{
Nome do (a) aluno (a): Mait Bertollo
}

Data da defesa: 15/02/2019

Nome do Prof. orientador: Ricardo Mendes Antas Jr.

Nos termos da legislação vigente, declaro ESTAR CIENTE do conteúdo deste EXEMPLAR CORRIGIDO elaborado em atenção às sugestões dos membros da comissão Julgadora na sessão de defesa do trabalho, manifestando-me plenamente favorável ao seu encaminhamento e publicação no Portal Digital de Teses da USP.

São Paulo, 09/04/2019

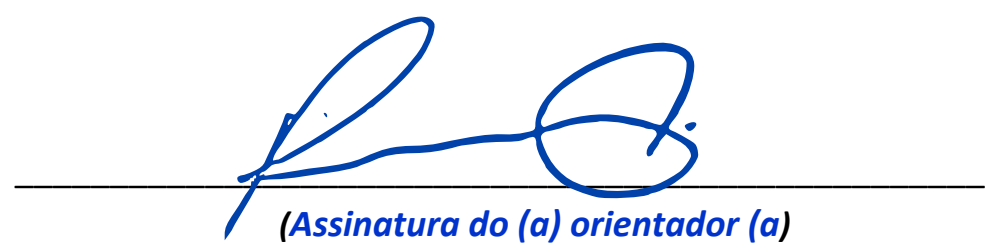


Nome: BERTOLLO, Mait

Título: A capilarização das redes de informação no território brasileiro pelo smartphone

Tese apresentada à Faculdade de Filosofia, Letras e Ciências Humanas para obtenção do título de Doutora em Geografia Humana.

Aprovada em:

\section{Banca examinadora}

Prof. Dr. Sérgio Amadeu da Silveira

Julgamento: Aprovado
Instituição: Universidade Federal do ABC (UFABC)

Assinatura:

Prof. Dr. Ricardo Abid Castillo Instituição: Universidade Estadual de Campinas (Unicamp)

Julgamento: Aprovado

Prof. Dr. Fábio Betiolli Contel

Julgamento: Aprovado
Assinatura:

Instituição: Universidade de São Paulo (USP)

Assinatura: 


\section{Agradecimentos}

À Coordenação de Aperfeiçoamento de Pessoal de Nível Superior - Brasil (CAPES) PROEX 0487, cujo financiamento viabilizou esta pesquisa.

A meu orientador, Prof. Dr. Ricardo Mendes Antas Jr., por sua dedicação, incentivo, orientação rigorosa e ao mesmo tempo generosa, o que me deu uma formação sólida e proficiente.

Ao Prof. Dr. Sérgio Amadeu da Silveira e ao Prof. Dr. Fábio Betiolli Contel, que compuseram a banca do exame de qualificação e a banca julgadora da tese, cujas recomendações precisas e profícuas foram de suma importância para as reflexões sobre a pesquisa, como também para minha formação.

Ao Prof. Dr. Ricardo Abid Castillo, que compôs a banca julgadora da tese, pelas observações e recomendações que incentivam a continuidade dos estudos e pesquisa no tema.

Ao Prof. Dr. Hervé Théry e a André Nagy, pelos mapas desta tese e pelo que aprendi sobre cartografia.

A todos os funcionários da Secretaria de Pós-Graduação do Departamento de Geografia.

A Ana Elisa Rodrigues Pereira e aos demais colegas do Laboratório de Geografia Política e Planejamento Territorial e Ambiental (LABOPLAN).

Àqueles que contribuíram com seu companheirismo e incentivo: Alcides Manzoni Neto, Ana Carolina Sotratto, André Pasti, Carin Carrer Gomes, Carina Merheb, Carlos Leitão, Fábio Tozi, Fernando Coscioni, Flávio Vendrusculo, Flora Gal, Helena Meidani, Isabela Luhr Trad, Mariana Ramos, Melissa Steda, Michele Nicolau, Rosa Ortiz e Tiago Macambira.

A meus pais, Isabel e Eliomar, minha irmã, Luana e minha sobrinha, Helena, pelo apoio e pelo carinho. 
- Objetos inanimados, vocês têm então uma alma? - Talvez não, mas uma política sim.

Bruno Latour, 2004 


\section{RESUMO}

BERTOLLO, MAIT. A capilarização das redes de informação no território brasileiro pelo smartphone. 2019. 241 f. Tese (Doutorado em Geografia Humana) - Faculdade de Filosofia, Letras e Ciências Humanas, Universidade de São Paulo, São Paulo, 2019.

A capilarização da informação no território brasileiro por meio do smartphone e suas implicações espaciais são resultado da convergência das técnicas de telefonia e internet, cuja rede expande seu alcance para atender à demanda crescente de conexão, sob a regulação de agentes públicos e privados que determinam a implementação e o uso dessas infraestruturas. Os sistemas técnicos que compõem essa rede se fundamentam em lógicas, intenções e investimentos, induzindo seu aperfeiçoamento para a produção e o consumo desses objetos e das informações que por eles fluem de forma banalizada. O papel do smartphone é de conector e ponto de acesso, e seu funcionamento presume uma lógica reticular, pela qual as redes e as distâncias não contíguas não impedem relações cotidianas. As resultantes espaciais dos movimentos de produção, consumo, distribuição e capilarização dessa rede incidem em diferentes escalas do território, sob a influência das relações interescalares e de ordens e intencionalidades de agentes envolvidos no controle dessa rede.

Palavras-chave: Capilarização da informação. Smartphone. Território. Internet. WhatsApp. 


\begin{abstract}
BERTOLLO, MAIT. The information networks capillarization in Brazilian territory through the smartphone. 2019. $241 \mathrm{f}$. Tese (Doutorado em Geografia Humana) - Faculdade de Filosofia, Letras e Ciências Humanas, Universidade de São Paulo, São Paulo, 2019.

The information networks capillarization in Brazilian territory through the smartphone and its spatial implications are the result of the telephony and internet techniques convergence, whose network expands its reach to meet the increasing demand for connection, under the regulation of public and private agents that determine the implementation and use of these infrastructures. The technical systems that make up this network are based on logic, intentions and investments, inducing their improvement for the production and consumption of these objects and the information that they flow in a trivial way. The role of the smartphone is of connector and access point, and its operation presumes a reticular logic, in which the networks and the noncontiguous distances do not impede daily relations. The spatial results of the movements of production, consumption, distribution and capillarization of this network affect different scales of the territory, under the influence of the interscalar relations and orders and intentionalities of agents involved in the control of this network.
\end{abstract}

Keywords: Capillarization of information. Smartphone. Territorry. Internet. WhatsApp. 


\section{RESUMEN}

BERTOLLO, MAIT. La capilarización de las redes de información en el territorio brasileño a través del smartphone. 2019. $241 \mathrm{f}$. Tese (Doutorado em Geografia Humana) Faculdade de Filosofia, Letras e Ciências Humanas, Universidade de São Paulo, São Paulo, 2019.

La capilarización de la información en el territorio brasileño a través del smartphone y sus implicaciones espaciales son resultado de la convergencia de las técnicas de telefonía e internet, cuya red expande su alcance para atender a la demanda creciente de conexión, bajo la regulación de agentes públicos y privados que determinan la demanda por implementación y uso de estas infraestructuras. Los sistemas técnicos que componen esa red se fundamentan en lógicas, intenciones e inversiones, induciendo su perfeccionamiento para la producción y el consumo de esos objetos y de las informaciones que por ellos fluyen de forma banalizada. El papel del smartphone es de conector y punto de acceso, y su funcionamiento presume una lógica reticular, en la que las redes y las distancias no contiguas no impiden relaciones cotidianas. Las resultantes espaciales de los movimientos de producción, consumo, distribución y capilarización de esa red inciden en diferentes escalas del territorio, bajo la influencia de las relaciones interescalares y de órdenes e intencionalidades de agentes involucrados en el control de esa red.

Palabras claves: Capilarización de la información. Smartphone. Territorio. Internet. WhatsApp. 


\section{LISTA DE FIGURAS}

Figura 1 - Origem dos produtos populares da Apple .................................................... 48

Figura 2 - O percurso da internet móvel no Brasil ......................................................... 96

Figura 3 - Diâmetro dos cabos de fibra ótica submarinos .............................................. 101

Figura 4 - Estrutura de um cabo de fibra ótica ............................................................ 101

Figura 5 - Componentes do sistema de conversão de dados em luz e vice-versa ............... 102

Figura 6 - Principais estruturas da rede suporte para conexão à internet ........................... 114

Figura 7 - Funcionamento de uma ERB .................................................................. 121

Figura 8 - Comunicação do smartphone com a ERB .................................................... 121

\section{LISTA DE QUADROS}

Quadro 1 - Telefonia fixa pós-privatização, Brasil, 2000 ............................................... 53

Quadro 2 - Sistemas técnicos e regulatórios de cada período........................................... 77

Quadro 3 - As camadas no modelo Open System Interconnection (OSI)....................... 90

Quadro 4 As camadas no modelo TCP/IP............................................................ 91

Quadro 5 - Tempo necessário para download de conteúdo on-line em diferentes velocidades de conexão............................................................................. 93

Quadro 6 Unidades de medida em bytes .............................................................. 93

Quadro 7 - Ranking dos sites mais acessados no Brasil em outubro de 2018 ................. 130

Quadro 8 - Ranking dos sites mais acessados no mundo em outubro de 2018 ................. 131 


\section{LISTA DE GRÁFICOS}

Gráfico 1 - Evolução da densidade telefônica - percentual de telefones no Brasil em 1948-1991

Gráfico 2 - Arranjos populacionais de 100 mil até 750 mil habitantes, Brasil, 2016 ...... 143

Gráfico 3 - Arranjos populacionais com mais de 750 mil habitantes, Brasil, 2016 ....... 144

Gráfico 4 - Acessos móveis no Brasil, em milhões, 2016 ............................................ 158

Gráfico 5 - Cobertura das principais empresas de telecomunicação no Brasil, por população e tipo de domicílio, 2016 ........................................................ 159

Gráfico 6 - Abrangência da rede 4G no Brasil, por população e tipo de domicílio, 2016 ... 160

Gráfico 7 - Cobertura 2G, 3G e 4G entre 2005 e 2013, por número de municípios,

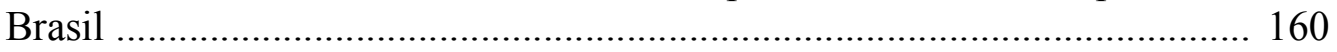

Gráfico 8 - Distribuição dos provedores regionais, por município e por número de

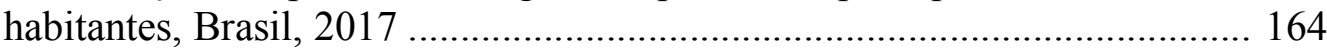

Gráfico 9 - Dispositivos de acesso no Brasil, em milhões de pessoas, por região, 2016 ... 165

Gráfico 10 - Dispositivos de acesso no Brasil, em milhões de pessoas, por renda, 2016 ... 165

Gráfico 11 - Download, criação de conteúdo e compartilhamentos no Brasil, em milhões de pessoas, por região, 2016

Gráfico 12 - Acessos para serviços ou busca de informações, em milhões de pessoas,

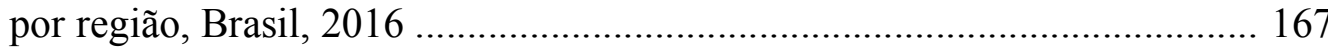

Gráfico 13 - Acessos à internet no Brasil, em porcentagem de pessoas, por renda, 2016 ... 167

Gráfico 14 - Atividades multimídia no Brasil, por região, 2016 .................................... 168

Gráfico 15 - Percentual de telefones fixos e smartphones nos domicílios, por região, Brasil, 2016

Gráfico 16 - Comparação entre a carga informacional das unidades federativas segundo a teledensidade

Gráfico 17 - Municípios que oferecem rede wi-fi pública e gratuita no Brasil, por unidade da federação, 2017

Gráfico 18 - Acesso a informações por televisão ou smartphone no Brasil, por região, 2016

Gráfico 19 - Motivos da não utilização da internet .......................................................... 188

Gráfico 20 - Uso da internet no Brasil, por região, 2016 ............................................... 189

Gráfico 21 - Motivos pelos quais as pessoas não possuem smartphone, por percentual da população, Brasil, 2017 ....................................................................... 190

Gráfico 22 - Crescimento anual da produção de smartphones no Brasil, em milhões ...... 194

Gráfico 23 - Percentual do uso do aplicativo WhatsApp, por eleitores dos candidatos à presidência

Gráfico 24 - Percentual de eleitores que compartilham notícias sobre política brasileira e eleições por meio do aplicativo WhatsApp 


\section{LISTA DE MAPAS}

Mapa 1 - Estações rádio base implantadas no município de São Paulo, 2018 ................ 25

Mapa 2 - Rede telegráfica no globo, 1903 ................................................................. 34

Mapa 3 - Rede de backbone com capacidade agregada de $347 \mathrm{~Gb} / \mathrm{s}$ e capacidade internacional de $116 \mathrm{~Gb} / \mathrm{s}$, Brasil, 2016

Mapa 4 - Cabos submarinos internacionais que ligam o Brasil a outros países e continentes, 2018

Mapa 5 - Cabos submarinos internacionais, 2018

Mapa 6 - Cabos submarinos transatlânticos, empresas detentoras, comprimento e capacidade de transmissão, 2018

Mapa 7 - Presença e velocidade da rede de banda larga na região Sul, Brasil, 2018

Mapa 8 - Presença e velocidade da rede de banda larga nas regiões Sudeste e CentroOeste, Brasil, 2018

Mapa 9 - Presença e velocidade da rede de banda larga na região Nordeste, Brasil, 2018

Mapa 10 - Presença e velocidade da rede de banda larga na região Norte, Brasil, 2018 ... 120

Mapa 11 - Número de usuários de smartphone no Brasil, por unidade da federação e por região metropolitana, 2016

Mapa 12 - Acesso à internet e uso de dispositivos: computadores e smartphones no Brasil, por unidade da federação, 2016

Mapa 13 - Anamorfose dos usuários de smartphone, por unidade da federação, Brasil, 2016

Mapa 14 - Usuários de smartphone segundo a faixa de renda (em salários-mínimos), por unidade da federação e por região metropolitana, Brasil, 2016

Mapa 15 - Usuários de smartphone por unidade da federação, Brasil, 2016 154

Mapa 16 - Sistemas operacionais de smartphone na RMSP, 2016 155

Mapa 17 - Sistemas operacionais de smartphone nos estados de São Paulo e do Rio de Janeiro, 2016

Mapa 18 - Sistemas operacionais de smartphone no Brasil, 2016

Mapa 19 - Número de usuários com acesso a telefonia móvel, por plano e por unidade da federação, Brasil, 2016

Mapa 20 - Porte das empresas provedoras de internet, por número de pessoas ocupadas e por unidade da federação, Brasil, 2018

Mapa 21 - Relação entre população e número de smartphones no Brasil, por unidade da federação, 2016

Mapa 22 - Distribuição das ERB no território brasileiro, 2018

Mapa 23 - Distribuição das ERB na região Centro-Oeste, 2018

Mapa 24 - Distribuição das ERB na região Norte, 2018

Mapa 25 - Distribuição das ERB na região Nordeste, 2018 ............................................ 175

Mapa 26 - Distribuição das ERB na região Sul, 2018 ..................................................... 176

Mapa 27 - Distribuição das ERB na região Sudeste, 2018 ............................................. 177

Mapa 28 - Concentração geográfica de operações com moedas virtuais, 2018 


\section{LISTA DE SIGLAS E ACRÔNIMOS}

\begin{tabular}{|c|c|}
\hline $1 \mathrm{G}$ & primeira geração \\
\hline $2 \mathrm{G}$ & segunda geração \\
\hline $3 \mathrm{G}$ & terceira geração \\
\hline $4 \mathrm{G}$ & quarta geração \\
\hline $5 \mathrm{G}$ & quinta geração \\
\hline AFP & Agência France Press \\
\hline AM & amplitude modulation \\
\hline ANATEL & Agência Nacional de Telecomunicações \\
\hline $\mathrm{CCC}$ & Central de Comutação e Controle \\
\hline CERN & European Organization for Nuclear Research \\
\hline CIA & Central Intelligence Agency \\
\hline CNPJ & Cadastro Nacional da Pessoa Jurídica \\
\hline $\mathrm{CPqD}$ & Centro de Pesquisa e Desenvolvimento \\
\hline CTB & Companhia Telefônica Brasileira \\
\hline DARPA & Defense Advanced Research Projects Agency \\
\hline DDD & discagem direta à distancia [chamadas nacionais de longa distância] \\
\hline DNS & Domain Name System \\
\hline DoD & Department of Defense \\
\hline DoE & Departament of Energy \\
\hline EDGE & enhanced date rates for GSM evolution \\
\hline EFE & Agência EFE [agência espanhola de notícias] \\
\hline EMBRATEL & Empresa Brasileira de Telecomunicações \\
\hline ENID & Eixos Nacionais de Integração e Desenvolvimento \\
\hline ERB & estação rádio base \\
\hline FM & frequency modulation \\
\hline GPRS & General Packet Radio Service \\
\hline GPS & Global Positioning System \\
\hline GSM & Global System for Mobile communications \\
\hline GVT & Global Village Telecom \\
\hline HD & hard disk \\
\hline
\end{tabular}




\begin{tabular}{|c|c|}
\hline IA & inteligência artificial \\
\hline IBGE & Instituto Brasileiro de Geografia e Estatística \\
\hline IP & internet protocol \\
\hline ISO & International Standard Organization \\
\hline ISP & Internet Service Provider \\
\hline LGPD & Lei Geral de Proteção de Dados \\
\hline LGT & Lei Geral de Telecomunicações \\
\hline LTE & Long Term Evolution \\
\hline NASA & National Aeronautics and Space Administration \\
\hline $\mathrm{NIH}$ & National Institutes of Health \\
\hline NSF & National Science Foundation \\
\hline OEA & Organização dos Estados Americanos \\
\hline OSI & Open Systems Interconnection \\
\hline PASTE & sistema postal \\
\hline PGMQ & Plano Geral de Metas de Qualidade \\
\hline PGMU & Plano de Metas de Universalização \\
\hline PGO & Plano Geral de Outorga \\
\hline PIB & produto interno bruto \\
\hline PNAD & Pesquisa Nacional por Amostra de Domicílios Contínua \\
\hline PNBL & Planos Nacionais de Banda Larga \\
\hline PRODASEN & Secretaria de Tecnologia da Informação \\
\hline PRODESP & Companhia de Processamento de Dados do Estado de São Paulo \\
\hline RENPAC & rede de pacotes \\
\hline RMSP & Região Metropolitana de São Paulo \\
\hline RNP & Rede Nacional de Ensino e Pesquisa \\
\hline RRE & Royal Radar Establishment \\
\hline SEI & Secretaria Especial de Informática \\
\hline SWIFT & Society for Worldwide Interbank Financial Telecommunication \\
\hline TELEBRAS & Telecomunicações Brasileiras S.A. \\
\hline TSE & Tribunal Superior Eleitoral \\
\hline www & world wide web \\
\hline
\end{tabular}




\section{SUMÁRIO}

INTRODUÇão

CAPÍTULO 1

DA REDE DE TELEFONIA CONCENTRADA À CAPILARIZAÇÃO INFORMACIONAL NO TERRITÓRIO

1.1 Primeiro período: do pós-Segunda Guerra Mundial (1939-1945) até a década de 1990 - a implantação do sistema de telecomunicações pelo Estado brasileiro e as primeiras corporações presentes na rede

1.1.1 Antecedentes do primeiro período: infraestruturas no fim do século XIX e início do século XX - formação do sistema técnico

1.1.2 Pós-Segunda Guerra e a convergência da informação e da comunicação ....

1.1.3 Financiamento do desenvolvimento do celular para smartphone

1.2 Década de 1990: expansão da rede pelo Estado e corporações no território

1.2.1 O evento da privatização das redes e uma nova organização do sistema ....... 50

1.2.2 Inovação das redes técnicas na década de 1990 ........................................... 57

1.3 Período atual: a simultaneidade capilarizada

1.4 Da expansão à capilarização das redes

CAPÍTULO 2

SISTEMAS TÉCNICOS NO TERRITÓRIO PARA USO DO SMARTPHONE E A INFORMAÇÃO CAPILARIZADA

2.1 O objeto técnico smartphone: as novas práticas sociais que transformam o território

$2.2 \mathrm{O}$ objeto técnico smartphone

2.3 Técnica e território: capilarização da informação pelas redes e realização da simultaneidade através de cabos de fibra ótica (backbones)

2.4 A rede serviço que percorre a rede suporte

2.5 Capilarização das ERB no território

2.6 Espectro eletromagnético para conexão de smartphones: 2G, 3G, 4G

2.7 Outras redes que capilarizam a informação no território pelo uso do smartphone e pela conexão à internet

2.8 O papel do smartphone como coletor de informações: tratamento das informações dos usuários e economia da informação

2.9 Agentes que modulam dados: robôs e algoritmos 


\section{CAPÍTULO 3}

CAPILARIZAÇÃO DA INFORMAÇÃO PELO SMARTPHONE NO TERRITÓRIO

BRASILEIRO E A DINÂMICA NA REDE URBANA ATUAL

3.1 Características da rede urbana brasileira e distribuição das redes .................... 138

3.2 Arranjos populacionais da rede urbana brasileira ........................................ 143

3.3 Distribuição dos smartphones e usos no território ........................................... 146

3.4 Interações espaciais condicionadas pelo smartphone: difusor de informação e motivador da comunicação

3.5 Incidência das normas nas cidades: empresas de telecomunicação, Estado e o condicionamento do uso das redes

3.6 Uso do smartphone no território brasileiro: redes de conexão e acesso ............ 164

3.6.1 A rede wi-fi gratuita nas cidades........................................................... 180

3.7 Capilarização da informação pelo smartphone e hierarquia e heterarquia urbanas

CAPÍTULO 4

CAPILARIZAÇÃO DA INFORMAÇÃO E O ALCANCE DAS AÇÕES VERTICAIS ............. 184

4.1 Direito ao acesso à tecnologia e à comunicação: os desconectados da rede .....

4.2 Capilarização dos serviços de internet por smartphone: bitcoin, blockchain e compartilhamento.

4.3 O smartphone e o condicionamento do cotidiano nas esferas de consumo e produção

4.4 Reconhecimento de usuários e a influência dos algoritmos em seu comportamento

4.5 Capilarização da informação pelo aplicativo WhatsApp em smartphones

4.6 Eleições 2018 e smartphone: evento e objeto

CONCLUSÃo 


\title{
INTRODUÇÃO
}

\begin{abstract}
Se pode afirmar que o nascimento de uma filosofia técnica no nível dos conjuntos só é possível através do estudo profundo das regulações, da informação. Os verdadeiros conjuntos técnicos não são aqueles que utilizam indivíduos técnicos, mas aqueles que são um tecido de indivíduos técnicos em relação de interconexão.

A máquina é somente um meio, a finalidade é a conquista da natureza, a domesticação das forças naturais: a máquina é um escravo que serve para fazer outros escravos.

Uma inspiração desse tipo, dominadora e escravista, pode topar com a reivindicação de liberdade para o homem. Mas é difícil se liberar transferindo a escravidão a outros seres, sejam homens, animais ou máquinas. Reinar sobre um povo de máquinas que converte em escravo o mundo inteiro segue sendo reinar, e todo o reino supõe aceitação de esquemas de servidão.
\end{abstract}

Gilbert Simondon, 2007

Nesta tese, procuramos compreender como a capilarização das informações pelo smartphone no Brasil se constitui num movimento de grande mudança no uso do território, devido às novas possibilidades oferecidas à maior parte da população pela conexão à internet em pontos não contíguos e pelas formas interescalares de interação que essa mudança ensejou de modo mais frequente e intenso.

A capacidade de receber e usar as informações em diferentes lugares e o intercâmbio imediato de ideias podem resultar no exercício da liberdade de expressão e na organização política ou submeter-se ao controle de corporações, Estados e outros agentes políticos e econômicos cuja interferência se expande no campo comunicacional, informacional e cognitivo, influenciando comportamentos e ações no território.

As relações entre o uso do smartphone e o uso do território se baseiam na correspondência entre as redes presentes sobretudo nas cidades e a transformação de suas dinâmicas a partir da inserção e do uso desse objeto técnico que medeia várias formas complementares, indispensáveis e mesmo antagônicas - entre usuários e corporações que controlam as tecnologias telemáticas e proveem acesso à internet para comunicação, obtenção de dados e produção de informações e vigilância.

Por meio da intensa participação dos indivíduos na rede, as tradicionais relações hierárquicas entre as cidades podem ser relativizadas e às vezes compatíveis com relações heterárquicas, isto é, mais horizontais e com certa equidade entre os centros urbanos. O uso 
do smartphone em todas as faixas de renda e faixas etárias no Brasil, diferenciado por classe social em razão dos valores do serviço e dos dispositivos, permite o encadeamento entre várias escalas - do macro (corporações, instituições, Estados, governos e organizações de solidariedade) ao micro (indivíduos com propósitos de uso pessoal) -, o que dá mais eficiência às ordens e ações hegemônicas capilarizadas no território, produzindo um corte transversal das escalas, sem mediação entre agentes globais e locais.

As ações possibilitadas pela capilarização das informações de forma pulverizada pelo território estabelecem novas relações espaço-temporais na vida social, como a extração de dados pessoais dos usuários e sua manipulação para várias finalidades, que hoje são decisivas no planejamento e na produção do espaço geográfico, portanto, no devir social de um lugar ou região, estabelecidos por intencionalidades na organização do território.

A atuação dos agentes da rede suporte e da rede serviço, que conectam smartphones à internet, mostra-se fundamental e revela suas implicações na sociedade, cada vez mais condicionada e dependente dos objetos técnicos desenvolvidos com desígnios científicos e informacionais.

Assim, partimos da tese de que a capilarização da informação de forma banalizada no território se de deve à popularização do smartphone, que promove uma transformação profunda e significativa no uso do território brasileiro, tornando-o mais racionalizado e corporativo para agentes hegemônicos políticos e econômicos, engendrando comportamentos e mudanças territoriais.

Ressalta-se que a integração do território, possibilitada pelos novos meios de comunicação, não atinge igualmente todos os pontos, mas há uma integração seletiva e uma conexão parcial do território.

O acesso a informação e comunicação é entendido como um bem e uma questão que tange aos direitos humanos, combinado com as implicações espaciais da conexão às redes no território brasileiro como resultado histórico e espacial de uma modernização seletiva e incompleta, com disponibilidade desigual de infraestruturas em muitas de suas porções. 
As redes estabelecidas para fazer funcionarem os smartphones - compostas por antenas, satélites, espectro eletromagnético, cabos de fibra ótica e redes $2 \mathrm{G}, 3 \mathrm{G}$ e $4 \mathrm{G}$ (segunda, terceira e quarta geração de telefonia móvel) - usam estruturas cuja implementação demanda um tipo de investimento de capital e determinado período de tempo. O uso do smartphone atinge de forma qualitativamente diferenciada todos os estratos sociais de todas as regiões brasileiras, induzindo o aperfeiçoamento específico das técnicas de produção e consumo desses objetos, que se estruturam de forma massificada. As resultantes espaciais dos movimentos de produção, consumo, distribuição e capilarização dessa rede são importantes e incidem em diferentes escalas do território nacional.

Para uma análise espacial pelo método adotado, consideramos os sistemas de objetos, em particular, o smartphone, fundamental nesta investigação, bem como o conjunto de redes organizadas para seu acesso à internet. A implementação e a conexão são plenamente dependentes de políticas estatais, governamentais e corporativas, dada sua organização no território por meio de grandes infraestruturas.

Acrescem-se a importância e a influência da informação para controle e gestão de inúmeras atividades dispersas, considerada "vetor fundamental do processo social" (SANTOS, 1996, p. 66). A informação participa da constituição territorial pela regulação da vida humana, mediada por objetos que obedecem a imposições tecnológicas e financeiras, pilares do atual período de globalização.

O partido teórico adotado define o espaço geográfico como "conjunto indissociável de sistemas de objetos naturais ou fabricados e de sistemas de ações, deliberadas ou não. A cada época, novos objetos e novas ações vêm juntar-se às outras, modificando o todo" (SANTOS, 1994, p. 23). Assim, os objetos tornam-se cada vez mais técnicos e específicos, e são fabricados e localizados para melhor responder a objetivos previamente estabelecidos, enquanto as ações tendem a ser cada vez mais racionais e tornam os objetos técnicos tanto mais eficazes quanto melhor se adaptam às ações econômicas, políticas ou culturais.

A relação do território com o smartphone é instrumental, para disseminar informações e determinar a atuação mais racional sobre inúmeros e variados pontos do território. Esse sistema técnico disseminado, presente em várias porções territoriais, se superpõe aos anteriores sob o comando de agentes hegemônicos da economia, cultura e política. Esse é um 
dado fundamental do processo de globalização, que não seria possível se não houvesse essa unicidade técnica ${ }^{1}$ (SANTOS, 1994).

Cabe ainda reforçar que entendemos que o espaço geográfico é uma instância social e se "articula à economia, à política, ao direito e à cultura como conjuntos de fatores, funções e valores que condicionam a produção e reprodução social" (SANTOS, 1996, p. 46). Logo, a seleção, o tratamento e a reflexão sobre os dados do uso do smartphone no Brasil são analisados sob a ótica espacial.

O território brasileiro abriga um conjunto de aparatos que constitui a internet, particularmente, as funções da rede serviço e a rede suporte. Integrada pelas operadoras de telefonia e internet, a rede suporte é constituída por um sistema de objetos técnicos imbricados e sobrepostos. A rede serviço é efetivada por sites web e aplicativos, totalizando o conteúdo que circula nesse sistema técnico e com crescente aperfeiçoamento dos mecanismos de som, imagem e dados, o que exige mais assistência da rede suporte para aumentar velocidade, fluidez e capacidade de armazenamento.

Para um acesso mais eficiente à rede serviço, há uma pressão contínua de diferentes âmbitos da sociedade - usuários individuais, empresas de todas as grandezas, instituições nacionais, internacionais, multilaterais etc. - por mais conectividade no território. O intenso fluxo entre os agentes envolvidos na rede impõe um ritmo de resposta cada vez mais rápido às demandas de comunicação para expansão e capilarização dessas redes.

O smartphone é um objeto conector e um ponto de acesso que dissemina a ação da rede serviço nos territórios. $\mathrm{O}$ uso individual e o grande número de usuários resultam numa densidade informacional inédita, pelo desenvolvimento das tecnologias da informação e da comunicação combinadas à digitalização dos conteúdos de texto, áudio e vídeo que passaram a ser arquivos de dados e se reproduzem em qualquer sistema informático, concomitante ao incremento e ao aperfeiçoamento das técnicas de conexão.

\footnotetext{
${ }^{1}$ De acordo com Milton Santos (1994, p. 45), a unicidade técnica "é um sistema de objetos que, pela primeira vez na história do homem, tende a ser o mesmo em toda parte [...]. Esses objetos novos formam os sistemas hegemônicos, surgidos para atender às necessidades das ações hegemônicas e [...] surgem debaixo de um comando único e já aparecem dotados de intencionalidade [...]. São objetos técnicos que representam sistemas técnicos, dotados de uma mecânica própria e funcionalidades próprias, e é nessa condição que aceitam ou recusam funções transmissoras dos processos. Esses sistemas técnicos contemporâneos hegemônicos são capazes de uma força de invasão de qualquer outro sistema já instalado, estabelecendo sobre a face da terra uma área de combate que é, ao mesmo tempo, a base da dinâmica e o substrato da dialética do espaço”.
} 
Acessada por meio do smartphone, a internet é uma rede com múltiplos nós, conectada a outras redes, controlada e difusa entre muitos pontos, mediada por serviços e aplicações e que funciona hierarquicamente numa lógica de mercado. A inclusão/exclusão da rede é respaldada pela massificação do acesso por um modelo de consumo de alto custo econômico e com obstáculos normativos e políticos à melhoria da conexão. $\mathrm{O}$ crescente uso do smartphone e da participação de usuários nessa rede que capilariza a informação no território promove interações escalares, uma vez que um indivíduo, uma empresa ou uma instituição podem acessar diferentes recortes do território para mobilizar processos segundo seus interesses e finalidades.

Nesse contexto, amplia-se o conceito de mobilidade, que agora ultrapassa a ação de movimento e locomoção e começa a envolver:

[...] a capacidade do agente (indivíduo, empresa, instituição) de fazer movimentar bens ou mercadorias e também informação banal ou produtiva [...] o grau de mobilidade de um agente também se mede por seu poder político e/ou econômico de desencadear fluxos materiais e fluxos informacionais (CASTILLO, 2017, p. 643).

Para tratar dessas diretrizes sucintamente descritas aqui, o Capítulo 1 estrutura uma periodização com base nas camadas técnicas nos diferentes momentos de planejamento, organização e implementação do smartphone, tratando historicamente os processos que antecederam e participaram de sua construção. A periodização procura apontar as antigas e as novas relações interescalares motivadas pela capilarização dos sistemas técnicos de telecomunicação e como a distribuição dos fenômenos e suas relações ao longo de um processo histórico resultam territorialmente no presente.

A periodização parte do fim da Segunda Guerra Mundial. A flexibilização e a intensificação dos movimentos de globalização dos anos 1970 até os 90 estabeleceram as bases para que grandes empresas estatais se tornassem propriedade de corporações globalizadas. Nos anos 1990, houve a grande mudança do paradigma do telefone fixo para o telefone móvel até o uso banalizado do smartphone e a capilarização das informações, com a presença hegemônica de empresas privadas no ramo da telefonia.

Assim, partiu-se da estruturação de redes pretéritas pouco ou nada interativas até o advento das redes digitais interativas que herdaram essas infraestruturas, desenvolvendo técnicas de telecomunicações e comunicações via satélite no começo da década de 1970 até o 
presente, quando a transformação da cibernética, da informática e da eletrônica permitiu que essas diversas técnicas se comunicassem e levassem à convergência dos momentos, assegurando a simultaneidade das ações e, por conseguinte, acelerando o processo histórico (SANTOS, 1996).

No Capítulo 2, discutimos o smartphone e a indissociabilidade entre os sistemas de objetos e os sistemas de ações, questão teórica que norteou o levantamento empírico e documental para compreender as transformações no território e a repercussão do objeto na sociedade.

A conexão entre esses objetos técnicos para capilarizar a informação pelo smartphone se dá por uma cadeia de humanos e não humanos (LATOUR, 2001), em que os sistemas de ações são permeados por atuações técnicas, corporativas e intencionalidades humanas, composto de várias redes, com pontos e intersecções em várias regiões e países conformando uma unicidade técnica (SANTOS, 1994).

Logo, por meio da implantação de sistemas técnicos no território, entende-se a história dos lugares, considerando que os objetos técnicos se realizam em conjunto, produtos de determinada sociedade em dado período, em que as redes suporte e as redes serviço funcionam como influenciadoras de práticas sociais, políticas, econômicas e culturais.

O Capítulo 3 investiga o ordenamento das infraestruturas técnicas da rede capilarizada pelo smartphone no território, que têm como suporte principal as estações rádio base (ou antenas), os cabos de fibra ótica nacionais e transnacionais e o espectro eletromagnético.

Sua implementação e distribuição no território nacional decorrem da herança de desigualdades estruturais, sociais e econômicas, o que restringe o acesso à conexão, aliada às definições do mercado sobre quem pode arcar com os custos do acesso à rede. Nesse contexto, o Marco Civil da Internet é considerado um normalizador das ações das empresas fornecedoras de serviços de conexão, sobretudo as corporações Facebook e Google. 
Podemos notar a indissociabilidade entre o fenômeno da urbanização e o meio técnico-científico-informacional ${ }^{2}$ num território das dimensões do Brasil, onde a comunicação e conexão entre os pontos, fundamental e estratégica, sempre foi difícil por ter sido tradicionalmente centralizada. $O$ advento do smartphone e a banalização de seu uso transformaram as interações a partir do momento em que um número crescente de pessoas passou a se comunicar. A capilarização das informações deu nova dinâmica de funcionamento à sociedade, e ainda não há resposta a fenômenos e eventos que estão em andamento.

Finalmente, o Capítulo 4 aborda a rede de smartphones e a densidade informacional dada pelo número de seus usuários. Essa distribuição revela a intensificação das interações espaciais fomentadas pela mudança das práticas comunicativas, especialmente nas cidades.

No meio do processo de pesquisa, na primeira avaliação exigida para o doutoramento (comumente chamada exame de qualificação), foi definido que trabalharíamos a capilarização das informações por meio do smartphone e com alguma análise a partir de aplicativos, e o WhatsApp surgiu como uma possibilidade, pois já despontava como o aplicativo mais usado no Brasil.

Em outubro de 2018, já na fase final da redação desta pesquisa, transcorreram as eleições presidenciais e parlamentares, o que reforçou nossa tese sobre os novos usos do território pela capilarização da informação por meio do smartphone, permitindo que nos detivéssemos, ainda que brevemente, nesse evento marcado pelo uso do smartphone e, consequentemente, do aplicativo WhatsApp.

Assim, a atual rede de telecomunicações é um importante objeto de estudo que permite compreender a inter-relação entre as diversas escalas, pois os fluxos de informações que a percorrem são mutáveis e condicionam, por intermédio do sistema financeiro integrado mundialmente, a organização econômica e política dos lugares, do mesmo modo que influenciam as práticas sociais, dada a importância da informação na vida cotidiana, tornandose corriqueira quando convergem comunicação e computação, em que digitalização de dados e informações para difusão e tratamento de mensagens eletrônicas, juntamente com suas intencionalidades, produzem a massificação da informação banal.

\footnotetext{
${ }^{2}$ O meio técnico-científico-informacional (SANTOS, 1996) representa a atual etapa do sistema capitalista de produção e as transformações do espaço geográfico relativas, sobretudo, à Terceira Revolução Industrial, também chamada Revolução Científica Informacional, a partir dos anos 1970, quando, guiada pelo funcionamento do mercado no processo de globalização, a união entre técnica e ciência se torna ainda mais evidente e frequente. Além de ser técnicos, os objetos carregam em si a informação.
} 


\title{
CAPÍTULO 1
}

\section{DA REDE DE TELEFONIA CONCENTRADA À CAPILARIZAÇÃO INFORMACIONAL NO TERRITÓRIO}

\begin{abstract}
O telefone inicial evoluiu lentamente, ao longo de várias gerações. Era uma vez um dispositivo mais estranho, com fone e microfone, um mantido com cada mão. Você tinha que girar uma manivela para gerar um sinal que tocaria a campainha na outra extremidade da linha. A transmissão de voz era fraca. Ao longo dos anos, as melhorias foram feitas lentamente em tamanho e forma, realidades e recursos que simplificaram seu uso. $O$ instrumento era pesado e robusto: caía no chão, mas você raramente perdia a conexão telefônica. $O$ layout do mostrador ou os botões de pressão resultaram de uma experimentação cuidadosa em laboratório. O tamanho e o espaçamento das chaves foram cuidadosamente projetados para produzir feedback. Pressione um botão e você ouvirá um tom no fone de ouvido. Fale no microfone, e uma porcentagem cuidadosamente determinada de sua própria voz era alimentada de volta para o fone de ouvido, o melhor para ajudá-lo a regular o quão alto você estava falando. Cliques, zumbidos e outros ruidos que você ouvia enquanto uma conexão estava sendo estabelecida forneceram indicações úteis de progresso.
\end{abstract}

Donald Norman, 1988

O alto número de usuários de smartphone ${ }^{3}-5$ bilhões distribuídos pelo globo (GSM, 2018), dos quais 220 milhões ativos em muitas porções do território brasileiro (FGV, 2018) revela que, no período atual, seu uso se relaciona não só às grandes corporações e ao Estado, mas está banalizado e expandido em praticamente todos os estratos da população. Os indivíduos que possuem esse objeto compõem o movimento de capilarização e distribuição das redes pelo território, que conectam a internet aos smartphones, presentes sobretudo nas cidades que são os principais nós das redes urbanas, com influência crescente da circulação de informações e da comunicação entre indivíduos.

Essa rede digital é mais distribuída e usada do que a rede de telefonia fixa (praticamente analógica num período passado), embora ainda hoje existam disparidades regionais e lugares sem condições de acesso à internet. A estrutura de telefonia fixa, que passou a ser também de internet, teve nas cidades os pontos prioritários de conexão. As cidades são uma escala importante, pois cresceram e se estruturaram como os nós, juntamente com as redes de comunicação, principalmente em países de terceiro mundo, onde a riqueza se concentra nas metrópoles e nas zonas urbanas.

\footnotetext{
${ }^{3}$ Grafamos smartphone e internet em redondo, pois são muito recorrentes neste trabalho. As demais palavras estrangeiras estão em itálico, conforme a norma.
} 
O smartphone é um aparelho comunicador sem fio (independente da distância, ao contrários dos telefones sem fio) que agregou dados e voz por meio de um sistema informacional de computadores, oferecendo novas possibilidades de uso para comunicação e recebimento e emissão de informações em muitos pontos onde a telefonia fixa era incapaz de chegar por seu tipo de tecnologia e porque o sistema técnico correspondente condicionava uma distribuição mais restrita e concentrada.

Da concentração das redes de telefonia fixa no território até a capilarização da rede informacional e digital do smartphone, consideramos que a centralização e a capilarização não são polos opostos: a telefonia fixa era concentrada e menos capilarizada, e o comando informacional e a implantação de redes em mais pontos do território foram realizados por grandes corporações do setor de telecomunicações e internet e resultaram numa maior distribuição e capilarização desses serviços, estando o poder de comando dessas redes concentrado em alguns poucos lugares do planeta.

Esse movimento de capilarização dos sistemas técnicos que viabilizam a comunicação e a conexão criaram condições para a emergência de uma rede sem fío que liga o aparelho a um receptor, o que permite novos usos em muito mais pontos do território, que acolhem, por exemplo, as antenas chamadas de estações rádio base (ou ERB) em vários lugares que a telefonia fixa não alcançava, podendo atender concomitantemente até 200 conexões de aparelhos.

A distribuição das ERB pelo território brasileiro é basilar para o funcionamento das redes $3 \mathrm{G}, 4 \mathrm{G}$ e, em breve, $5 \mathrm{G}$. Um grande número de estações rádio base opera numa vasta área como uma rede integrada sem fios, permitindo a partilha ininterrupta da transmissão sem interferências quando os usuários se movem, mesmo em alta velocidade. Essas redes foram projetadas para conexões sem fio, e o Mapa 1 mostra todas as ERBs licenciadas pela Agência Nacional de Telecomunicações (Anatel) no município de São Paulo, que usam redes herdadas e condições topológicas de cada porção onde estão instaladas. 
Mapa 1 - Estações rádio base implantadas no município de São Paulo, 2018

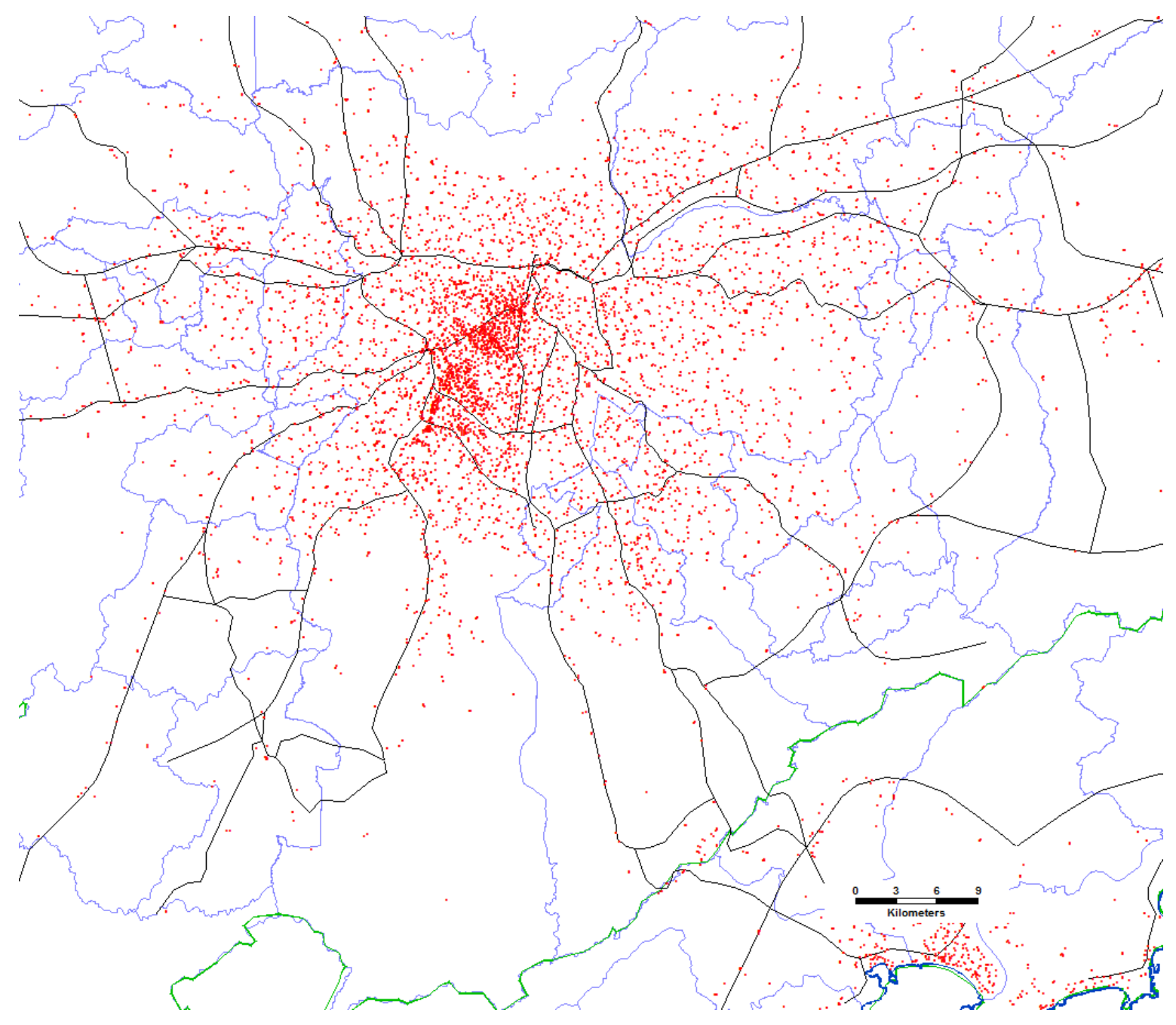

Legenda

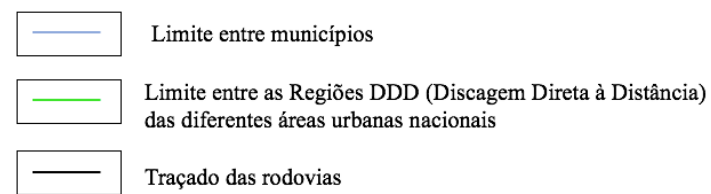

- Estação Rádio Base (ERB)

Fonte: Anatel (2018b).

Organização: Mait Bertollo.

Elaboração: André Rodrigues Nagy. 
Nota-se a concentração da implementação das redes na porção central do município de São Paulo que se estende ao longo de rodovias, apresentando dispersão e menor densidade ao se distanciar do centro, acompanhando, de certa forma, a densidade demográfica. Dada a configuração espacial desse sistema de objetos técnicos, ${ }^{4}$ abrem-se possibilidades de um novo funcionamento, organização e uso do território a partir da emergência das novas tecnologias da informação pela capilarização dessa rede, baseada numa integração eletrônica corporativa de pontos selecionados.

No período atual, as relações econômicas, sociais e espaciais têm mediação das redes eletrônicas formadas pelos sistemas de telecomunicações e informacionais, cuja coerência se dá por um conjunto de protocolos de códigos que conectam dispositivos e compõem a internet como conhecemos. A integração do território por numerosas redes é potencializada pelas transformações resultantes do período de globalização. A disparidade entre os tipos e a densidade dessas redes aprofunda as diferenças no território, principalmente nas cidades, resultando em refuncionalizações no espaço urbano e no acolhimento de diversos sistemas e objetos como o smartphone e seu uso condicionado pelas redes de internet.

A demanda de fluidez e velocidade na troca de dados, mensagens, informações e capitais é crescente, transformando as cidades e munindo o território de novos sistemas de objetos para atendê-la. As redes efetivam diferentes modos de inserção do capital, na forma de investimentos em infraestrutura que transformam profundamente a rede urbana.

As redes de telecomunicação implantadas resultam de políticas públicas e também da capacidade de retorno do capital investido pelas empresas, momento em que se define a quais redes este ou aquele cidadão terá ou não acesso.

A partir dos anos 1990, o processo de privatização de empresas públicas mudou o acesso e a abrangência das redes técnicas, e as ações das empresas de telefonia transformaram o espaço urbano com a instalação de cabos, postes, antenas e outros grandes objetos desse sistema.

A partir da popularização do uso dos smartphones, no começo dos anos 2000, foram estabelecidas outras relações entre os usuários e as cidades, pela capilarização da internet, a maior densidade comunicacional e uma relação interescalar global - redes transnacionais,

\footnotetext{
${ }^{4}$ Objetos técnicos são aqueles que cumprem o critério do uso possível promovendo conexão, aproximação,
} vizinhança, apropriações e usos distintos (SANTOS, 1996). 
proprietárias da rede suporte e da rede serviço. As redes informacionais que permeiam a sociedade atual buscam estabelecer novas relações sociais sob o imperativo da velocidade (MATTELART, 2002).

A capilarização da internet por smartphone no território brasileiro é entendida aqui sobretudo no sentido da distribuição capilar da informação, que tende a atingir cada indivíduo da população no território (SCUTRON, 2007; DICIONÁRIO DE CIÊNCIAS SOCIAIS, 1986). A capilaridade no território depende de um tipo de conduto específico de cada sociedade ou, em termos geográficos, suas características tangem às particularidades de cada formação socioespacial ${ }^{5}$ (SANTOS, 1996).

Esta pesquisa aborda principalmente os canais de circulação que abrangem as estruturas do sistema de telecomunicação e, em particular os smartphones, como extremidades da rede de internet. A natureza e a estrutura das instituições têm influência no processo de capilaridade, e os indivíduos estão sujeitos a essas transformações, pois capilarizar uma infraestrutura como essa permite o uso do sistema mais descentralizado.

Ao apreender as redes sob a ótica espacial, considera-se que cada fixo tem características técnicas e organizacionais correspondentes aos fluxos. Os fluxos determinam nos fixos uma característica social na sua interação (SANTOS, 1988). Esses elementos constituem as redes de infraestrutura entendidas como rede suporte que permite transportar elementos tangíveis e não tangíveis através de linhas e nós cujo dado social é a participação das pessoas e dos valores que permeiam ou constituem a própria rede (SANTOS, 1996).

A rede suporte e rede serviço específicos da internet promovem conjuntamente a capilarização e a circulação de informação no território, cujas variáveis de localização, densidade e qualidade de funcionamento conformam, de um lado, os espaços da globalização e, de outro, os espaços com pouca ou nenhuma conexão no período técnico-científicoinformacional:

\footnotetext{
5 Segundo Santos (1977, p. 45), o acréscimo da dimensão espacial à categoria formação econômica e social expressa o modo de produção, formação social e espaço como categorias interdependentes: "Todos os processos que, juntos, formam o modo de produção (produção propriamente dita, circulação distribuição e consumo) são histórica e espacialmente determinados num movimento de conjunto, e isto através de uma formação social".
} 
[...] os suportes das redes encontram-se parcialmente no território, nas forças naturais dominadas pelo homem (o espectro eletromagnético) e parcialmente nas forcas recentemente elaboradas pela inteligência e contidas nos objetos técnicos (por exemplo, o computador). Desse modo, quando o fenômeno de rede se torna absoluto, é abusivamente que ele conserva esse nome. $\mathrm{Na}$ realidade, nem há mais propriamente redes; seus suportes são pontos (SANTOS, 2009, p. 264).

Existem divergências e convergências entre os proprietários das redes suporte, constituídas pelas operadoras e corporações que implementam e controlam infraestruturas como cabos, antenas e espectro eletromagnético, e os proprietários e as redes serviço, compostas por empresas que proveem serviços virtuais através da World Wide Web (WWW) e de aplicativos, de que se servem financeira e comercialmente.

As corporações que detêm a rede suporte pressionam as empresas que provêm serviços virtuais como aplicativos e sites a pagar pelo uso da rede, pois realizam atividades comerciais com base em infraestruturas estabelecidas e mantidas por terceiros. Ao mesmo tempo, existem firmas detentoras de sites da web, como Facebook e Google, por exemplo, que proveem conteúdo e serviços da rede e que têm algumas infraestruturas próprias ou pressionam para maior capilarização e potência do sistema para fazer fluírem mais dados e informações com mais velocidade e mais poder de penetração no território, intensificando a distribuição em inúmeras fases de ramificações ou, numa palavra, capilarizando seus serviços. Logo, essas grandes corporações são proprietárias da rede suporte e também da rede serviço.

O mecanismo de penetração das redes no território, que aqui chamamos de capilarização, aumentam as possibilidades de disseminação do poder, dado o papel dos agentes corporativos e estatais na circulação e comunicação pela flexibilidade da rede, que se adapta a situações diversas (RAFFESTIN, 1993) e condiciona transformações no território sob o modo de produção no qual ela está inserida. Elas são inerentes às redes geográficas (CORREA, 1999) que foram e são instituídas a partir da distribuição na superfície terrestre de localidades que se articulam por meio dos mais variados fluxos e vias, conformando o que se entende por "sistemas de movimento do território que se constituem em um conjunto indissociável de sistemas de engenharia e de fluxos que respondem pela solidariedade material entre os lugares" (CONTEL, 2011a, p. 16), isto é, várias redes de infraestrutura imbricadas na escala do território nacional.

O papel dos fluxos de informação na integração do mercado interno e externo brasileiro implica a presença de várias redes de telecomunicação conectadas. Elas se 
ampliaram a partir de sua renovação tecnológica, alterando sua distribuição espacial e a capilarização das redes usando novos objetos, redesenhando várias porções do território e, portanto, diferenciando-o do de um passado recente (DIAS, 1995a).

Quando surge o telefone nas cidades, surgem as redes de telecomunicação e cria-se a possibilidade de se diminuírem distâncias, visto que eram colocadas em contato imediato duas pessoas distantes, realizando a simultaneidade num processo de eliminação das distâncias (DUPUY, 1981). Assim, desde o telefone até o smartphone, demanda-se uma rede que desempenha um papel importante na reestruturação das cidades, permitindo a distribuição e descentralização de atividades que se podem realizar por meio das telecomunicações.

A rede é entendida como significado de fios entrelaçados e nós e, segundo Musso (2001), o termo latino retis, de onde deriva rede, surge no fim do século XII, ligado às noções de organismo, corpo e técnica:

\begin{abstract}
A simbologia da rede sempre esteve ligada a uma técnica e às práticas associadas: a sua origem é questão de fios e de tecido, da rede de pesca ou da cestaria, de forma artesanal do reticular, pois, com a revolução industrial, a rede se tornou mecanismo autorregulado notadamente graças ao pistão e à máquina a vapor; hoje, a rede se apresenta como uma técnica autoorganizada, realizada pelo computador, e qualificada de "inteligente". De outro lado, essas variações da concepção de rede ligada às evoluções técnicas abriga metáfora constitutiva que associa a rede a um organismo vivo. Isto é, a simbologia da rede se forja na dupla referência de imagens do corpo e da máquina. É no entrecruzamento dessas representações e de suas evoluções que o conceito e o imaginário da rede são construídos, em seguida são degradadas (MUSSO, 2001, p. 195).
\end{abstract}

Sistema técnico que define um tipo de organização espaço-temporal e que depende da implementação de elementos concatenados sobre um território, a rede afeta desde a temporalidade global até a local, de acordo com os tipos e a velocidade dos fluxos. Sua eficiência e rapidez dependem de sua matriz técnica e, nas redes de telecomunicação, a capacidade de transmissão de fluxos de informações e dados demanda um desenvolvimento técnico com transmissão mais rápida, e a qualidade e distribuição desses objetos técnicos definem a ampliação ou redução da conexão à rede.

A partir daí, a rede pode ser concretizada como matriz técnica, representando formas e estruturas como as de transporte e comunicação - rodovias, ferrovias, telégrafo -, implicando mudanças na relação espaço-tempo, cuja principal referência são a técnica e os objetos instalados no território. 
A composição da rede se desenha conforme se inserem diversos elementos em vários momentos, segundo o movimento social. De acordo com Milton Santos (1996), o processo de formação das redes tem três fases: a pré-mecânica, quando as redes se formam espontaneamente, em razão de o homem ainda estar sob o domínio das forças naturais, a mecânica intermediária, quando a rede se produz pelo desenvolvimento técnico, e a atual, que se manifesta na complexidade das técnicas inseridas na sociedade, com suporte territorial para a maioria das redes e o desenvolvimento tecnológico, com as ações efetivas dos fluxos informacionais do período presente, como elementos diferenciais em relação às outras fases.

Nesses três momentos, as redes se diferenciam pelo uso, pela participação dos agentes em sua construção e em sua própria circulação, além da capacidade de fazer movimentaremse elementos tangíveis e intangíveis dentro da rede.

É importante ressaltar que a distribuição irregular das redes na superfície terrestre se dá pela impossibilidade de cobrir totalmente o território com essas infraestruturas, seja por condicionantes sociais, econômicos, políticos e mesmo naturais.

Por isso, a capilarização é tratada aqui como capilarização geográfica, considerando que $76 \%$ da população brasileira se encontra em áreas predominantemente urbanas, que correspondem a apenas 26\% dos municípios (IBGE, 2017). No Brasil, as áreas consideradas urbanas representam $0,63 \%$ do território nacional e concentram 160 milhões de pessoas, isto é, 84,3\% da população (FARIAS et al., 2017).

Toda a população urbana está concentrada em núcleos, e o termo capilarização não significa que o smartphone e a internet estão em cada fragmento do território, mas que está distribuído em cada concentração. Pelo estudo da rede sob a ótica da capilarização geográfica, considera-se a demografia e sua distribuição, a história do território e a organização econômica e política da sociedade. Como metáfora, a capilarização induz ao entendimento errôneo de que cada indivíduo, em cada fração do território, possui um smartphone e tem acesso à internet.

A existência e influência das redes no território é resultado de seu uso e só se efetiva no processo de ação, pois "as redes são técnicas, sociais, materiais, viventes, animadas por fluxos, estáveis, dinâmicas, ativas e não passivas, globais e locais, unas e múltiplas, concentradoras e dispersoras, integram e desintegram, destroem recortes espaciais e criam outros" (SANTOS, 1996, p. 126). 
A circulação e a comunicação são elementos primordiais para entender a rede e o uso do smartphone:

\begin{abstract}
A circulação e a comunicação são duas faces da mobilidade. Por serem complementares, estão presentes em todas as estratégias que os atores desencadeiam para dominar as superfícies e os pontos por meio da gestão e do controle das distâncias. Falaremos de circulação cada vez que se trate de transferência de seres e de bens lato sensu, enquanto reservaremos o termo "comunicação" para a transferência de informação. Ainda que, por mais útil que seja, essa distinção pareça ambígua, uma vez que poderá dar a entender que há apenas a circulação ou apenas a comunicação. Na realidade, em todo "transporte" há circulação e comunicação simultaneamente. Os homens ou os bens que circulam são portadores de uma informação, e assim, "comunicam" alguma coisa. Da mesma forma, a informação comunicada é, ao mesmo tempo, um "bem" que "circula" (RAFFESTIN, 1993, p. 200).
\end{abstract}

A circulação de bens, informações e indivíduos requer uma rede que começa por sua base técnica, que pode ser flexível, moldando-se conforme a situação:

A rede é proteiforme, móvel e inacabada, e é dessa falta de acabamento que ela tira sua forca no espaço e no tempo: tanto libera como aprisiona. É o porquê de ela ser o "instrumento" por excelência do poder [...]. Redes de circulação e comunicação contribuem para modelar o quadro espaçotemporal que é todo o território. Essas redes são inseparáveis dos modos de produção dos quais asseguram a mobilidade (RAFFESTIN, 1993, p. 204).

O atual modo de produção demanda uma fluidez que decorre da capacidade de adaptação às redes, das regras de uso e do acesso, num contexto em que o poder e as ordens se distribuem pelo território e têm um "modo de funcionamento segundo a metáfora de rede bicéfala: vigilância da circulação e circulação da vigilância" (MUSSO, 2004, p. 34). Assim, define-se uma nova relação espaço-tempo pela circulação na rede com a busca por instantaneidade ou simultaneidade e a velocidade do fluxo relativa à dimensão topológica, uma vez que o número de ligações e sua complexidade, como cruzamentos e bifurcações, podem ser obstáculos que reduzem a velocidade em alguns pontos da rede.

Esse sistema técnico em rede é implantado segundo a divisão territorial do trabalho e da produção capitalista vigentes, que requerem-nas para fazer circularem o capital financeiro, ideias, dados, mercadorias, mensagens e os próprios agentes. Essas ações exigem fluidez, e sua velocidade define se a rede técnica é obsoleta ou não.

A periodização proposta aqui trata do processo de implementação das redes de telefonia, que se aprimorou por meio de inovações tecnológicas, tornando a rede mais complexa e mais capilarizada no território brasileiro e que associou, na segunda metade do 
século XX, a telefonia, a internet e a informática. Essas relações interescalares consideram os eixos da sucessão e da simultaneidade: como se foram distribuindo os fenômenos ao longo de um processo histórico e, atualmente, como se dão no território e que relações mantêm entre si (SANTOS, 1996).

Partimos da premissa de que "a periodização indica uma ação humana sobre o tempo e sublinha que seu recorte não é neutro" (LE GOFF, 2015, p. 12). Para conduzi-la, levamos em conta diferenças técnicas, de regulação e de funcionamento que regem a essência informacional das tecnologias dos sistemas de objetos hegemônicos e sua implantação no Brasil.

A história das redes é a história do desenvolvimento das técnicas e da disseminação de inovações: de acordo com Haesbaert (2004), as três vertentes básicas das redes provêm do âmbito político ou jurídico-político e tangem às relações entre espaço e poder político institucionalizados, estando o território submetido ao poder do Estado na maior parte das vezes. Também sofrem influência da esfera cultural ou simbólica, supondo "o território como produto da apropriação e valorização simbólica de um grupo em relação ao espaço que habitam; e o campo da dimensão espacial das relações econômicas, em que o território é fonte de recursos ou produto da divisão territorial do trabalho" (HAESBAERT, 2004, p. 40).

A implementação e capilarização de redes e de objetos conectores têm uma historicidade e, em geografia, a periodização é fundamental para assimilar as etapas e camadas das transformações espaciais. Os períodos tratados a seguir estão assim organizados: da segunda metade do século XX até a década de 1990, com a implantação do sistema pelo Estado brasileiro e as primeiras corporações presentes na rede, um segundo período na própria década de 1990 e a capilarização da rede híbrida pelo Estado e por corporações no território a partir do evento de privatização, e o terceiro período é o presente, com a simultaneidade capilarizada a partir do advento e do uso do smartphone. 


\subsection{Primeiro período: do pós-Segunda Guerra Mundial (1939-1945) até a década de 1990 - a implantação do sistema de telecomunicações pelo Estado brasileiro e as primeiras corporações presentes na rede}

Para melhor compreender esse período, retomamos alguns eventos importantes no Brasil que fundamentaram a instalação da rede de telecomunicações e suas mudanças técnicas ao longo do tempo. Nesse primeiro período, reúnem-se comunicação e tecnologia da informação, conformando as bases tecnológicas do advento do smartphone, no início dos anos 2000.

\subsubsection{Antecedentes do primeiro período: infraestruturas no fim do século XIX e início do século XX - formação do sistema técnico}

Alguns eventos ligados à expansão das redes de comunicação que antecederam a década de 1940 definiram a configuração dos sistemas técnicos de informação e comunicação. O invento e o uso mais descentralizado do telégrafo, a partir fim do século XIX, usava o código Morse para enviar sinais codificados por meio de pulsos elétricos transmitidos por cabo ou sinal de rádio.

O telégrafo elétrico e o código Morse $^{6}$ foram criados por Samuel F. B. Morse, nos EUA, na década de 1830, compondo o principal sistema de comunicação de longa distância no século XIX e no começo do XX, para fins comerciais, de informação, governamentais e pelas forças armadas.

A implantação dessa rede começa nos EUA, com uma linha entre Washington, Boston e Nova York, e, expandindo-se, configura as ligações globais do começo do século XX, em 1903 (Mapa 2).

No Brasil, a infraestrutura implantada e os eventos ocorridos no fim do século XIX e início do XX ainda eram muito concentrados e se aplicavam principalmente aos grandes centros localizados nas regiões Sul e Sudeste do país. Em 1879, as primeiras redes de

\footnotetext{
${ }^{6} \mathrm{O}$ código Morse usa um sistema de letras, algarismos e sinais de pontuação e se transmite por meio de corrente elétrica.
} 
telefonia foram implementadas na forma de concessão, aumentando o alcance das linhas interurbanas para municípios dos estados de São Paulo, Santa Catarina e Minas Gerais, o que estimulou a criação de algumas empresas de telefonia que, em 1916, se fundiram na Companhia Telefônica Brasileira (CTB). Em 1901, foi implantada a primeira central telefônica a bateria, na cidade de Porto Alegre (RS), com uma rede de cabos subterrâneos. As inovações que chegaram ao Brasil nesses momentos foram trazidas pela empresa concessionária canadense Brazilian Traction Light \& Power.

Mapa 2 - Rede telegráfica no globo, 1903

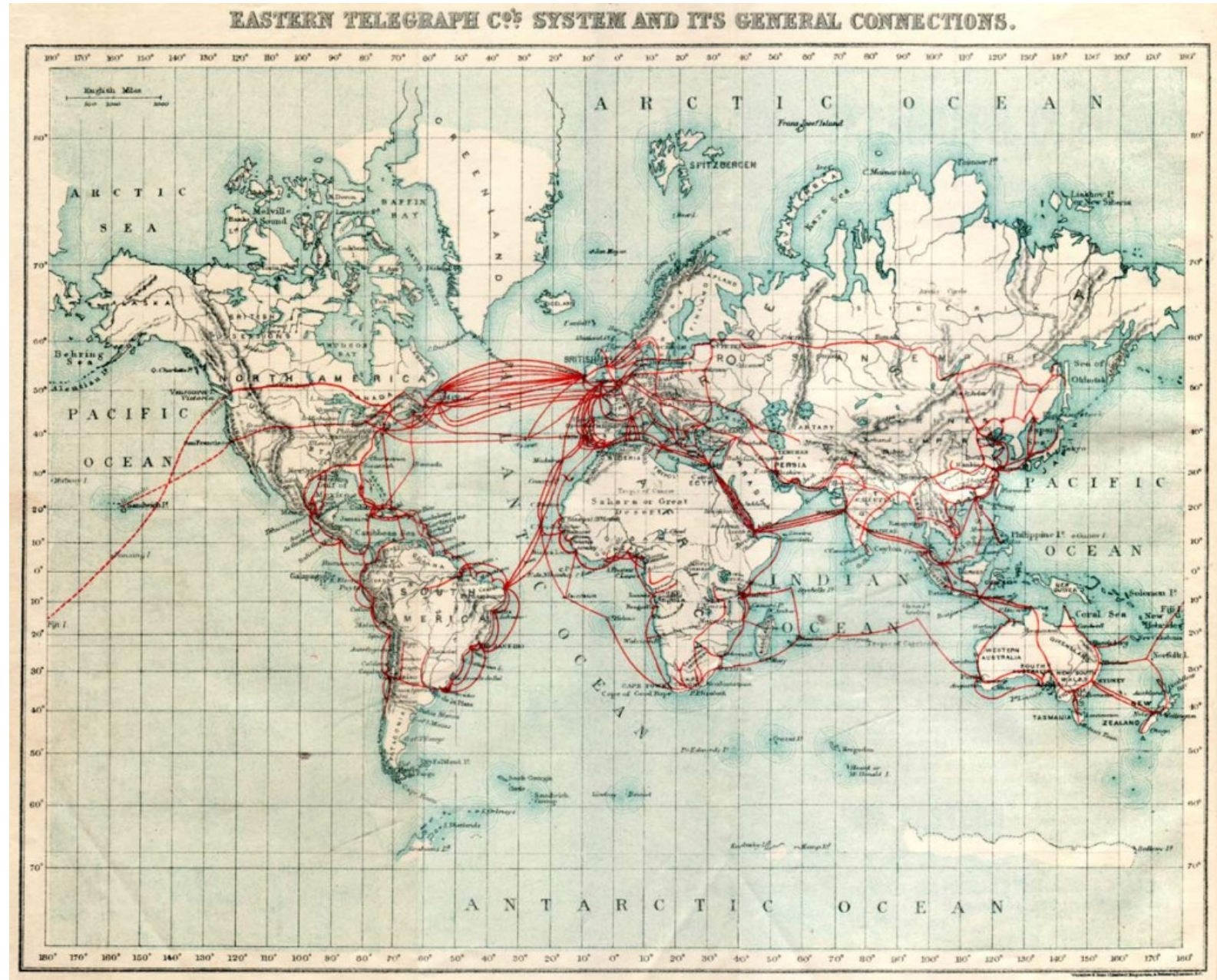

Fonte: The Atlantic Cable Maps (2018).

Os serviços de telefonia começaram a ser ampliados para ligações interurbanas e se intensificaram primeiramente na cidade do Rio de Janeiro (RJ): em 1920, foram instaladas quatro centrais telefônicas, e os assinantes do serviço passaram de 30 mil para 1,2 milhões. Em 1929, os telefones começaram a originar ligações do próprio aparelho, por meio da discagem dos números, com a instalação da primeira central automática na cidade. Crescia a 
demanda desse serviço, pois "a cidade e mais precisamente a burguesia de negócios urbanos que foi cliente do serviço de telefone permitiu seu desenvolvimento" (DUPUY, 1982, p. 78).

A distribuição desigual das primeiras linhas telefônicas revelou os principais centros econômicos do país, pois seus principais clientes eram comerciantes, políticos e industriais, estimulando a expansão das linhas:

O estado do Rio Grande do Sul e de São Paulo possuíam 76\% do total de telefones do país em 1913, sendo 39.478 telefones distribuídos por 18 unidades da federação, apontando para a emergência de novas formas de organização social e espacial - o trabalho assalariado e a urbanização (DIAS, 1995a, p. 117).

Em 1930, a CTB implementou os primeiros telefones públicos com cabines no Rio de Janeiro e, em 1972, começaram a funcionar as cabines abertas feitas de fibra de vidro, o chamado orelhão. A nacionalização de fato da telefonia, que extinguiu o recurso das concessões, foi realizada no governo de Juscelino Kubistchek, como parte da política de “substituição de importações”, em 1965, sob o Decreto n. 40.439.

\subsubsection{Pós-Segunda Guerra e a convergência da informação e da comunicação}

Após o fim da Segunda Guerra Mundial, houve um profundo e extenso desenvolvimento dos meios de comunicação pela demanda por transmissão de informações e pela maior necessidade de comunicação mais rápida e com menos barreiras.

Nos anos 1940-50, o território brasileiro viveu uma estagnação dos investimentos e falta de manutenção ou atualização das redes, resultado da dificuldade de importação de equipamentos devido à Guerra e à variedade de instâncias do poder público, com formas de gestão e de fixação de tarifas não padronizadas. Soma-se a isso a prioridade dada ao desenvolvimento do transporte rodoviário desde 1945 para integrar o mercado nacional, dado o processo de industrialização no governo de Juscelino Kubitschek:

[...] a estagnação das telecomunicações deve também ser atribuída à vigência, na época, de um sistema financeiro pouco desenvolvido, que admitia, por exemplo, que taxas de juros diferentes fossem aplicadas dentro do território nacional. A industrialização do país não foi acompanhada, num primeiro tempo, por uma reforma financeira, o que assegurou a permanência de mercados paralelos de crédito locais ou regionais (DIAS, 1995b, p. 123). 
A implementação da base técnica e econômica da rede de telecomunicação no Brasil nos 30 anos que antecedem a década de 1990 foi estabelecida numa conjuntura de reorganização das estruturas produtivas iniciada nos 1960, durante a ditadura militar, quando o sistema de comunicação se estruturou como elemento central para controle do território e para sistematizar e incentivar as transações econômicas que se potencializavam (RIBEIRO, A., 1991).

A expansão e apropriação desse sistema e a implantação da rede suporte resultaram da combinação de variáveis espaciais, econômicas, políticas, sociais e culturais. A ampliação da rede de telecomunicações e a implantação de redes de transmissão de dados tem início com ações coordenadas pelo Estado, para atender a demanda de serviços de telefonia e também com desígnio estratégico-militar, sob a ideia da "segurança nacional". Havia ainda um motivo econômico: a inovação tecnológica das redes e sua expansão possibilitaria o desenvolvimento e a conexão com a indústria local de telecomunicações e permitiria instituir uma estrutura nacional de pesquisa e desenvolvimento (BENAKOUCHE, 1995).

Fica claro que nesse período a elaboração e implementação das técnicas não foram um processo homogêneo e que também foram influenciadas pelo contexto da industrialização. No começo dos anos 1960, havia cerca de 800 companhias telefônicas, com 1 milhão de telefones para 70 milhões de habitantes, dificultando os investimentos estrangeiros:

Os investidores estrangeiros, quando vêm analisar as oportunidades oferecidas como mercado para novos empreendimentos, ficam surpresos com o grau de deficiência de nossa infraestrutura. Os meios de comunicação são precários e pouco rendimento oferecem no sentido de dar apoio às relações e trocas comerciais. Um aviso de crédito leva cerca de 30 dias. [...] Faltam-nos os serviços telefônicos e telegráficos. De São Paulo para o Rio de Janeiro e vice-versa, o drama da comunicação telefônica se agrava a cada dia que passa. Já não sabemos dizer qual a melhor hora, porque durante o dia as linhas estão ocupadas e à noite o interurbano não responde (RATTNER, 1967, p. 64).

A expansão da indústria e da economia nacional impulsionou medidas econômicas do governo militar para atualizar o sistema financeiro na forma de concentração bancária, além dos subsídios à produção agrícola, à exportação e à captação de recursos. Assim, os bancos nacionais começaram a fazer uma mediação entre bancos estrangeiros e o setor público, atraindo fundos no mercado internacional para financiar grandes projetos de infraestrutura (DIAS, 1995b). 
O modelo econômico global vigente exigia um sistema de telecomunicações como condição para concretizar suas práticas, adequando e reestruturando as redes no território. A partir dessa demanda, houve uma reorganização institucional do setor de telecomunicações: em 1965, foi criada a Empresa Brasileira de Telecomunicações e, em 1967, o Ministério das Comunicações. O custo dessas iniciativas, que estabeleceram condições técnicas e financeiras para que se ampliasse a rede em determinadas porções do território, foi bancado com dinheiro público. Até 1972, foi criada a Telecomunicações Brasileiras SA (Telebras) para conduzir a Embratel e companhias telefônicas estaduais e deliberar sobre o desenvolvimento da implementação de redes.

Os processos que envolveram a expansão das redes de comunicação nesse primeiro momento intensificaram as disparidades sociais e territoriais com a distribuição deliberada das infraestruturas próprias do chamado meio técnico-científico-informacional, que implica o "período do capitalismo de organização, período da inteligência, período técnico-científico em que a ciência e a técnica se tornaram a base de toda a vida do homem, de todas as suas realizações, de todas as relações sociais" (SANTOS, 1988, p. 12).

A consolidação desse meio e a base técnica implantada adequou a desigualdade social a um imaginário e a comportamentos humanos, arranjando a tecnologia e os valores produzidos por alguns setores da sociedade que promovem e influenciam os processos culturais que produzem e consolidam comportamentos (RIBEIRO, A., 1991).

Nos anos 1960, ao lado da veiculação de vídeos pela televisão, a difusão da capacidade de elaborar o devir para mediar numerosas práticas econômicas, políticas e culturais por meio da informática fomentou e antecedeu a expansão do meio técnico-científico no país cujos produtos difundidos pela televisão representavam uma parte limitada de um contexto econômico e político mais abrangente, em que se configurou mais intensamente a complementaridade entre os setores econômico, de infraestrutura e de mercado, com uma sofisticação de formas e processos da produção e do consumo:

Nesse momento, entre a produção e os mecanismos culturais que organizam, historicamente, a reprodução social com uso de instrumentos técnicos e culturais de interesses econômicos e políticos, foi possibilitada a intervenção no cerne do tecido social, de valores e princípios éticos (RIBEIRO, A., 1991, p. 50). 
O processo de acesso privilegiado das corporações às redes, que se intensificou a partir da década de 1960 teve um impacto sensível até o presente, no âmbito social e político, primeiramente pelos "produtos culturais" (RIBEIRO, A., 1991) difundidos pelo rádio e pela televisão e, por conseguinte, por outros objetos técnicos ligados à microeletrônica, à telefonia, às telecomunicações e à informática, que expandiram o poder de influência de forma generalizada.

Esses fluxos de informação começam a se concretizar mediante um sistema mais complexo, a partir de 1965, quando a Empresa Brasileira de Telecomunicações (Embratel) estendeu sua atuação para a transmissão de micro-ondas, orientando a estatização de alguns setores importantes em nome da segurança e da manutenção do regime militar. A CTB e suas subsidiárias foram estatizadas, e sua organização passou por mudanças pelas quais as numerosas prestadoras de serviço em atividade sob concessão das várias esferas do poder público - federal, estadual e municipal - iniciaram sua conexão pelas redes, num movimento para reverter sua precarização. A Embratel foi a base para articular o sistema, quando os principais serviços de telecomunicações se tornaram jurisdição da União (CERASOLI, 2000).

Em 1972, a Embratel foi transformada numa empresa de economia mista, e iniciou sua abertura para o mercado internacional. Como subsidiaria da Telebras, implementou a rede de telefonia pelo sistema telex e também na transmissão de dados (Renpac e Transdata), ${ }^{7}$ que constituiu um conjunto de infraestruturas e serviços que hierarquizou o sistema de redes contemporâneas de telecomunicações do país. Como uma estratégia de maior intervenção estatal, criou-se a Telecomunicações Brasileiras SA, ${ }^{8}$ empresa que tornou subsidiárias as concessionárias estaduais, sob o comando da Telebrás como holding. Também foram incorporadas 27 prestadoras de serviços, além da Embratel, a operadora de longa distância do sistema.

Esse conjunto de normas, eventos e redes pretéritas foi a base do sistema de telecomunicações num período em que instituições públicas e empresas precisavam usar a teleinformática em suas atividades ou para se comunicar com outros países por meio de redes telefônicas e de telex; na época, o acesso a bancos de dados era restrito.

\footnotetext{
${ }^{7}$ Renpac, ou Rede de Pacotes, é uma série de computadores instalados nas principais cidades brasileiras, ligados entre si por satélite ou por via terrestre. Quando os computadores ficam em contato permanentemente (como é o caso dos bancos), é necessária uma ligação direta e diligente, num tipo de linha continuamente aberta, com a ligação chamada Transdata.

${ }^{8}$ Constituída em 9 de novembro de 1972, por meio da Lei n. 5.792, de 11 de julho do mesmo ano.
} 
Do complexo conjunto de sistemas de objetos técnicos que compõem essa rede, destaca-se uma inovação importante: em 1971, o microprocessador ${ }^{9}$ deu mais eficiência e fluidez aos fluxos, por ser a base fundamental do uso de computadores. O principal objetivo do desenvolvimento técnico e científico desse componente tinha cunho militar e, passando depois a ser utilizado para fins civis, foi uma peça importante no desenvolvimento das técnicas de comunicação. A sofisticação dessas técnicas se intensificou com o início da corrida espacial, quando se lançaram na órbita terrestre os satélites que abriram caminho para a comunicação intercontinental, na década de 1970.

No contexto do II Plano Nacional de Desenvolvimento (1975-1979), as estratégias econômicas e de soberania moveram políticas ligadas à Telebras para estimular a expansão do mercado interno brasileiro e, por exemplo, comprar equipamento e criar empresas brasileiras. Em 1976, a Telebras instalou em Campinas-SP o Centro de Pesquisa e Desenvolvimento $(\mathrm{CPqD})$, para desenvolver tecnologias de ponta como comunicação por satélite, transmissão digital de comunicação ótica e desenvolvimento de centrais de comutação temporal para proceder à digitalização integral da rede de telecomunicações (DIAS, 1995b, p. 143).

A partir desses eventos, difundiram-se serviços como telefone e telex e também se diversificaram os serviços em uma única rede, com voz, imagem, texto e dados, fazendo convergirem as técnicas das telecomunicações e da informática, cujas bases são os circuitos integrados, substituindo o padrão eletromecânico pelo eletrônico. As inovações técnicas transformaram sons, imagens, textos e dados em bits.

Em razão do crescimento do uso de computadores no Brasil em 1975, o Ministério das Comunicações começou a articular ações para a transmissão eletrônica de dados e passou para a Embratel o encargo de instalar e explorar uma rede de transmissão de dados nacional, sem especificar as atribuições de cada empresa do sistema Telebras na execução. Em 1980, por meio da Portaria n. 006, a Secretaria Especial de Informática (SEI) criou a Comissão Especial de Teleinformática para conduzir de forma mais estruturada uma política de aperfeiçoamento e expansão dos serviços, garantindo o comando do Estado sobre o setor e o suporte para a indústria brasileira de microeletrônica (BENAKOUCHE, 1995).

\footnotetext{
${ }^{9}$ Microprocessador é um circuito integrado que cumpre as funções de cálculos, soluções e demais funções de um computador.
} 
Inicialmente, a finalidade era atender a demanda de grandes usuários como instituições e órgãos governamentais, bancos, empresas multinacionais e empresas de aviação, que antes usavam de redes telefônicas e de telex para desempenhar suas atividades e conectar-se com outros países. Nesse contexto, os bancos de dados governamentais, como o Instituto Brasileiro de Geografia e Estatística (IBGE), a Secretaria de Tecnologia da Informação (Prodasen) e a Companhia de Processamento de Dados do Estado de São Paulo (Prodesp) só podiam ser acessados pelo público interno (BENAKOUCHE, 1995).

A partir do período do último quartil do século $\mathrm{XX}$, as condições da vida econômica e social têm na informação um dado essencial e imprescindível (SANTOS, 1988), o que possibilitou a presença planetária de seu conteúdo, ensejando a aceleração do processo histórico contemporâneo: "na história da humanidade, é a primeira vez que tal conjunto de técnicas envolve o planeta como um todo e faz sentir instantaneamente sua presença" (SANTOS, 2001, p. 25). Essa presença se concretiza por meio das redes distribuídas para consolidação do poder e vigilância principalmente das corporações e dos Estados, que, por meio de sistemas técnicos como os satélites, passam a conhecer todos os lugares e captar momentos consecutivos, é não mais apenas fragmentos isolados do globo.

As grandes empresas de telecomunicação intensificaram suas estratégias globais específicas para atuar nos mercados onde se instalam. Assim, Estados e governos reconfiguram sua base normativa para acolher as normas dessas companhias a partir das privatizações, realizando concessões ou repartindo com a iniciativa privada nacional e internacional serviços, que antes eram públicos e estratégicos do Estado.

Para realizar a comunicação e prover acesso a informações, criou-se em 1980 a rede Transdata, constituída por circuitos privados ponto a ponto, ainda sem a tecnologia de comutação. No processo de comutação, ou de interligação de pontos, os dados são transmitidos do equipamento de origem ao elemento seguinte da comutação, que os registra e conduz ao outro e assim por diante, de modo que a mensagem é transportada pela rede até que o último elemento da comutação chegue ao aparelho de destino. Num sistema com essa configuração, a rede não estabelece necessariamente um tamanho para a mensagem, que pode ser enviada sem limites.

A rede Transdata tinha circuitos locados pela Embratel por um valor fixo, que era orçado pela distância entre os pontos a se comunicarem e pela velocidade da transmissão 
(medida em bits por segundo). Em 1985, havia 33 centros de transmissão em funcionamento e cerca de 10 mil circuitos alugados; já em 1987, havia aproximadamente 16 mil circuitos (um crescimento de $65 \%$ no período), ilustrando a crescente demanda de pedidos mensais de aluguel de novos circuitos pela Embratel (DIAS, 1995b).

As comunicações e trocas de informações e dados que ultrapassavam a fronteiras eram realizadas por meio dos serviços da Embratel pelas redes Interdata e Findata, que funcionavam em convênio com a agência Reuters, ambas públicas, as redes Airdata (usadas por empresas de aviação) e Interbank (ligada à rede SWIFT), ambas privadas.

A rede Swift (The Society for Worldwide Interbank Financial Telecommunication), ou Sociedade Mundial de Telecomunicações Financeiras Interbancárias, conforma um sistema pelo qual instituições financeiras globais enviam e recebem informações e realizam transações financeiras. A Swift também vende softwares e serviços para instituições financeiras que operam na Rede SWIFTNet e ISO 9362 usando códigos de identidade de negócios, que são os códigos de identificação de banco, os chamados códigos Swift.

A Swift foi fundada em Bruxelas em 1973, com a adesão de 239 bancos em 15 países, e, desde então, estabeleceu padrões para transações financeiras e também um sistema de processamento de dados numa rede global de comunicação e foi projetada e desenvolvida pela The Burroughs Corporation.

Até a primeira metade de 2018, a maioria das trocas de mensagens interbancárias internacionais usava a rede Swift, que tem conexão com aproximadamente 11 mil instituições financeiras em 200 países e perfaz uma média de 15 milhões de mensagens por dia. Essencialmente, a empresa envia ordens de pagamento que devem ser liquidadas por contas de correspondentes dos bancos.

Na segunda metade da década de 1980, as articulações da política nacional de telecomunicações expandiram o mercado ao público e, em 1985, começou a implantação da rede pública de transmissão de dados, a Renpac. Os principais impulsos para essa implementação foram o aumento da aquisição de microcomputadores e a possibilidade de conectá-los, o que já acontecia nos países centrais da Europa e nos EUA.

Nesse período, o papel dos microcomputadores nas empresas (grandes e pequenas) ainda era sobretudo facilitar as tarefas de administração, gestão de estoque e clientes e, em 
residências, existiam em menor número, com objetivos de lazer e gerenciamento das contas da casa. Nos dois casos, os dados eram tratados no próprio local, e ainda era baixa a demanda de acesso a informações. Criada na França por meio da rede Renpac, a técnica de comutação "por pacotes" tinha, em 1985, 13 centros de comutação e 13 centros de concentração espalhados pelo território brasileiro. A implantação dessa rede foi fundamentada por uma política de defesa e conhecimento do território no governo militar, motivando um planejamento regional para a implantação dos equipamentos.

Nesse momento, o acesso à rede era discado, por intermédio de circuitos urbanos e interurbanos de uso exclusivo, e o comutado, por meio de redes públicas de telefonia e telex. Nos dois casos, além de adquirir o equipamento - microcomputador, modem e software de acesso -, o usuário deveria fazer uma assinatura na Embratel, passando ao status de assinante, e escolher entre uma variedade de acessos à velocidade de transmissão.

Em 1987, a rede Renpac tinha apenas 110 assinantes (EMBRATEL, 1987), falhando o objetivo de ser popularizada. A estratégia de só oferecer a rede suporte, ou seja, a rede técnica de infraestrutura, não logrou atrair usuários, pois ainda não estava efetivada uma rede serviços que permitisse o uso eficiente da Renpac.

No fim da década de 1960, ainda havia no território grandes porções não integradas às redes de telecomunicação, e apenas duas ligações, por meio de micro-ondas, garantiam a conexão: uma entre Rio de Janeiro, São Paulo e Campinas e a outra entre Rio de Janeiro, Belo Horizonte e Goiânia. Nas outras porções do país, existiam as ondas curtas e os cabos submarinos, com pouca capacidade de transmissão de dados, de modo que as conexões eram precárias. Nesse contexto, a implantação de redes de micro-ondas do espectro eletromagnético e satélites ensejou a variedade dos serviços de telecomunicação.

Em meados da década de 1980, apesar de a rede integrar virtualmente todas as cidades brasileiras, eram desiguais o acesso e a distribuição dos serviços de telecomunicação pela rede suporte, e a infraestrutura das redes: 
Aplica-se a dois níveis distintos: de uma parte, aquele das infraestruturas de suporte, ou seja, redes técnicas que permitem o encaminhamento e o direcionamento dos fluxos; de outra parte, aquele dos serviços de comunicação oferecidos a partir dessa infraestrutura: rede telefônica, rede de transmissão de dados, rede de vídeo comunicação (CURIEN; GENSOLLEN $^{10}$ apud DIAS, 1995a, p. 50).

Como meio técnico, as redes de transmissão de dados e informações promovem circulação de informações de acordo com uma estrutura que estabelece seletivamente os pontos a serem conectados. A implementação das redes suporte procurou superar a falta de investimento desde o fim dos anos 1950, quando teve início o uso das ondas eletromagnéticas, a partir do fim da década de 1960, começando a integração por cidades do Centro-Sul até o Norte e o Nordeste do país. Em 1972, cerca de 55\% dos municípios tinham acesso a telefonia, mas a integração de todos os municípios à rede-suporte de telecomunicações só se completou em 1985.

No Brasil, o sistema de comunicação por satélite foi usado a partir do lançamento de seus próprios satélites: em 1985, o BRASILSAT 1 e, em 1986, o BRASILSAT II, produzidos pela empresa canadense Spar Aeroespace. Ainda que tenha havido uma importante expansão das redes suporte, seu alcance e densidade eram inferiores aos de outros países latinoamericanos como a Argentina (10,3\%) e o México (9,6\%) (Gráfico 1).

Gráfico 1 - Evolução da densidade telefônica - percentual de telefones no Brasil em 1948-1991

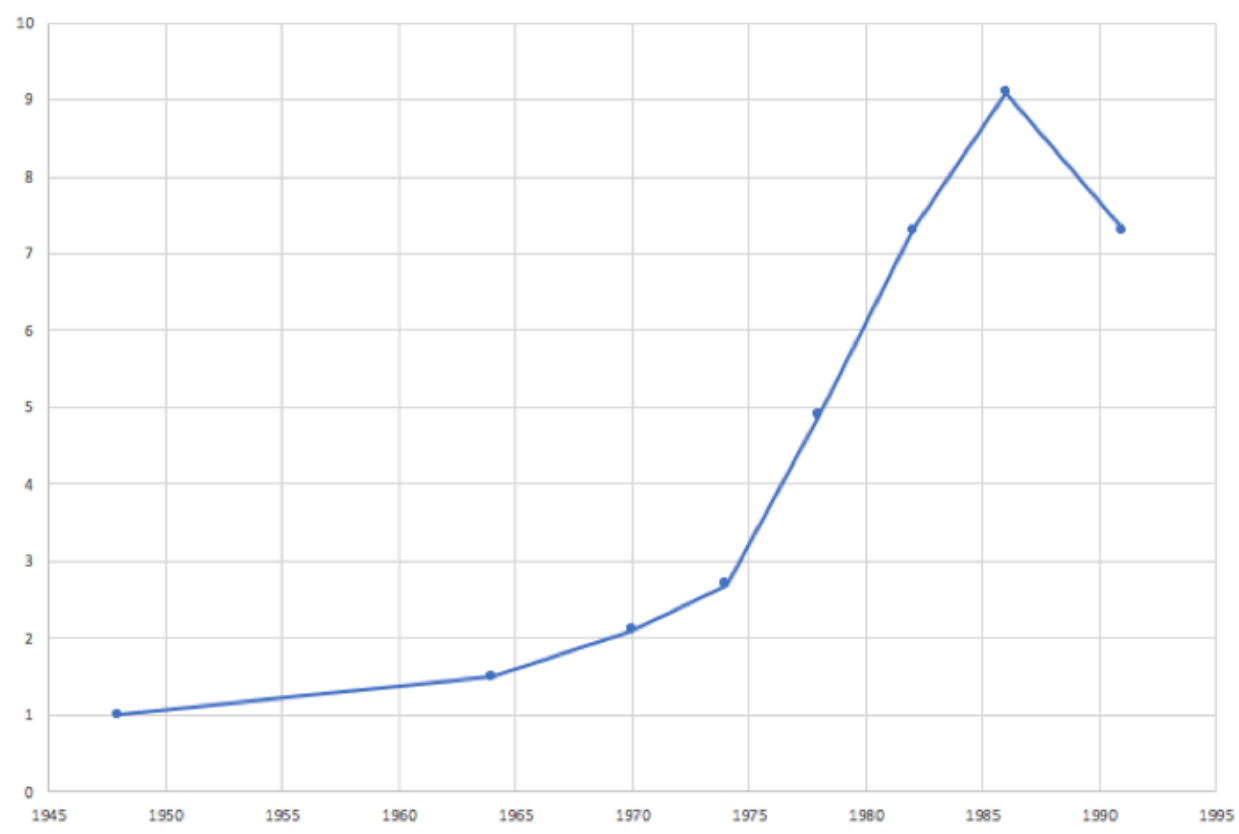

Fonte: Dias (1995a, p. 187).

Adaptação: Mait Bertollo.

10 CURIEN, N.; GENSOLLEN, M. Réseaux de télécommunications et aménagement de l'espace. Révue Géographique de l'Est, v. 25, n. 1, p. 47-56, 1985. 
Formada por circuitos ponto a ponto e multipontos e instalada em 1981 para responder à demanda de uso permanente para a transição de grandes quantidades de dados, a rede Transdata teve sua infraestrutura expandida, e, entre 1985 e 1991, seus circuitos passaram de 8.100 para 57.022, para atingir mais velocidade; ainda na década de 1990, para atender clientes do mercado financeiro e industrial, a Embratel introduziu o serviço de comunicação de dados via satélite em alta velocidade (DATASAT Plus). No entanto, a expansão só contemplou os clientes de telefonia de negócios, que aumentaram $86 \%$, enquanto a telefonia residencial aumentou apenas $20 \%$.

Até a década de 1990, a conexão entre as cidades brasileiras era centralizada em alguns pontos do território, de onde se comandavam atividades bancárias dispersas, manufatureiras e agrícolas, o que é ilustrado pela rede Transdata, que, em 1988, formava 14.867 circuitos que ligavam 804 centros urbanos (BENAKOUCHE, 1995).

Nessa conjuntura, a Região Metropolitana de São Paulo (RMSP) se consolidou como o principal nó da rede, a que conectava $84 \%$ dos centros urbanos integrados pela Transdata, seguida pela Região Metropolitana do Rio de Janeiro, conectando 14\% das cidades. Com menos capacidade de produzir, coletar, armazenar, distribuir informações e conectar cidades, num nível abaixo do Rio de Janeiro, as outras metrópoles eram Porto Alegre, Belo Horizonte, Brasília, Salvador, Recife, Curitiba e Campinas.

A metrópole de São Paulo ainda abrigava $40 \%$ das sedes dos bancos que atuavam no território nacional, sendo a principal praça financeira do país, diferentemente do Rio de Janeiro, que, na época, tinha a função de acolher atividades de mineração, metalurgia, construção naval, turismo e serviços públicos federais, sendo até hoje uma metrópole cuja força econômica são grandes empresas estatais.

Também há nós de redes em outras cidades do estado de São Paulo, destacando-se inicialmente as da RMSP como Osasco, Barueri, São Bernardo do Campo, Santo André e Guarulhos, dada a história de seu parque industrial automobilístico, que nasceu nos anos 1950 e se expandiu num anel de $50 \mathrm{~km}$ em torno da capital, e também pelo fenômeno da transferência das indústrias, empresas e centros de processamento de dados do centro de São Paulo para a periferia e o interior da RMSP em razão do aumento do valor da terra, nas décadas de 1960 e 1970 (DIAS, 1995b). 
No decorrer das transformações das redes, o sistema urbano foi se configurando por meio do "dado organizacional [que] é o espaço de fluxos estruturadores do território e não mais, como na fase anterior, um espaço onde os fluxos de matéria desenhavam o esqueleto do sistema urbano" (SANTOS, 1992, p. 20). Antes industriais, as metrópoles começam a se estabelecer como nós da rede de difusão de fluxos informacionais, agora com outros conteúdos e materialidades. Já no início da década de 1990, a RMSP detinha mais de 60\% do volume total de ligações internacionais na rede internacional de comunicações digitais via satélite (BENAKOUCHE, 1995).

As redes técnicas promovem diferentes movimentos nas redes urbanas, dispersando e concentrado atividades:

\begin{abstract}
A história da urbanização constitui, em grande parte, a história das redes técnicas. Com efeito, a dispersão das atividades econômicas pelo território e a concentração concomitante das funções de comando e de controle só foram possíveis no momento em que as relações sócio-espaciais adquiriram uma real fluidez. Houve, de início, as ferrovias e rodovias - eixos tangíveis -, que irrigavam o país com matérias-primas e mão-de-obra. Hoje em dia, se superpõem e se impõem os fluxos de informação - eixos invisíveis e imateriais certos, mas que se tornaram uma condição necessária a todo movimento de elementos materiais entre as cidades que eles articulam (DIAS, 1995a, p. 134).
\end{abstract}

Desde a década de 1960 até a de 90, as novas técnicas que incidiram no território brasileiro no âmbito financeiro, industrial e das telecomunicações foram encadeados com políticas econômicas, científicas e tecnológicas do governo militar desde 1964. Impostas sem um debate democrático com a sociedade civil e com o objetivo central de atender demandas de segurança nacional e favorecer o capital internacional, reorganizaram o território ao substituir o modelo eletromecânico pelo eletrônico. Assim, a expansão das redes suporte, como a de micro-ondas por satélites, começa ensejando o uso de diferentes redes serviço. Ressalta-se que a conexão dos pontos das redes suporte só se efetivou quando elas passaram a ser usadas por meio das redes serviço.

A expansão da rede telefônica se estabilizou e chegou a diminuir no fim dos anos 1990, ao contrário das redes de fluxos de informações e dados, que se desenvolveram e estenderam significativamente. Logo, as redes eletrônicas em vários pontos do território promoveram novas formas organizacionais de produção das grandes corporações e instituições do Estado. 
Destaca-se que, nesse momento, além de oferecer trabalho qualificado, recursos naturais e energia e acesso às redes de transporte, as vantagens locacionais nesse momento visavam fundamentalmente as redes de telecomunicação. A topologia dessa rede foi influenciada por empresas nacionais e internacionais que demandaram investimentos do Estado para sua criação e manutenção, indiferentes à democratização do acesso a essas redes.

Desde o planejamento dos pontos a serem contemplados até sua implementação, as redes de tecnologias da informação e comunicação recebem incorporação e atualização gradativas para mobilizar fluxos de informações, ideias, mercadorias e recursos financeiros. A estrutura que perfaz uma rede técnica, com vários nós e várias possibilidades de expansão, diagnostica e explora as potencialidades dos lugares e estabelece ligações interescalares que não necessariamente são contíguas no território e tampouco correspondem as condições históricas e da formação socioespacial, por exemplo.

Essas redes ativas e articuladas que propiciam velocidade de fluxos contêm ordens e acessam particularidades dos territórios e dos comportamentos sociais, principalmente por meio de propaganda e atividades ligadas à gestão econômica e política. $\mathrm{O}$ acesso a essa rede enseja também a articulação entre lugares antes distantes, o que favoreceu o processo de modernização da administração bancária:

Concomitantemente ao processo de diversificação e capilarização dos fixos geográficos que servem para a realização da intermediação financeira no território, há uma série nova de pontos de atendimento e canais de prestação de serviços financeiros que multiplicaram ainda mais a acessibilidade dos atores econômicos à finança. A essa maior banalização do acesso à finança, permitida pelos novos conteúdos da formação socioespacial brasileira, é que estamos propondo dar o nome de hipercapilaridade das finanças no território (CONTEL, 2011b, p. 113).

As disparidades da instalação de redes técnicas e as mudanças que levaram a uma sociedade de consumo resultaram na integração parcial do território. A rede técnica de informação e comunicação demonstrou a modernização incompleta do país, com configurações de comando que forjaram novos mecanismos de exclusão social. 


\subsubsection{Financiamento do desenvolvimento do celular para smartphone}

A mudança das técnicas ao longo do tempo - atualização, inovações e respostas às demandas de uso - servem à dinâmica da produção capitalista e dependem do Estado como grande financiador, desde as técnicas aplicadas aos transportes até a nanotecnologia, produtos farmacêuticos, sistema de internet etc. (MAZZUCATO, 2014).

No caso do desenvolvimento do smartphone, as inovações tecnológicas que tornaram smart o telefone celular ocorreram principalmente nos EUA e foram comercializadas e difundidas com financiamento do Estado, como as tecnologias ligadas às redes de internet, GPS, telas sensíveis ao toque e o comando de voz.

Ao contrário da lenda dos "gênios de garagem", esses investimentos de risco foram majoritariamente incentivados por instituições governamentais, cuja intervenção, considerando a teoria econômica convencional e contemporânea, é necessária quando o retorno social do investimento é maior do que o retorno privado. Em parceria com o setor privado, o Estado assume aqueles riscos que as empresas não admitem e se converte em empreendedor (MAZZUCATO, 2014) pois, além de reduzir os riscos do setor privado, é o principal incentivador das inovações e da economia.

Um exemplo da importância do subsidio estatal é o desenvolvimento da técnica do algoritmo, essencial para empresas como a Google e o Facebook. Essas inovações foram financiadas pela estadunidense Fundação Nacional de Ciências (National Science Foundation - NSF) na década de 1980. Nesse contexto, o Estado ainda teve um papel importante ao estimular a comercialização da internet até que, após quase 20 anos, investidores privados começassem a financiar empresas de biotecnologia, nanotecnologia e telecomunicações.

Os grandes produtores de smartphones concentraram esforços no desenvolvimento de tecnologia baseando-se em inovações realizadas em outros lugares, também com fomento estatal. A corporação Apple recebeu apoio direto e indireto de capital estatal estadunidense nas fases iniciais de criação e desenvolvimento, nas décadas de 1980 e 1990, quando obteve acesso às tecnologias militares ou desenvolvidas por instituições publicas de pesquisa, todas financiadas com recursos federais ou estaduais. Também se criaram políticas fiscais, comerciais ou de tecnologia de apoio a empresas como a Apple (MAZZUCATO, 2014). 
Entre as condições que viabilizaram smartphones, tablets e aparelhos MP3 e MP4, estão os indispensáveis microchips, que permitem armazenar grande quantidade de informações em dispositivos portáteis e usar espaço para memória virtual. As unidades centrais de processamento de dados e informações dependem de pequenos circuitos integrados com grande capacidade de memória, cuja herança são os circuitos integrados para processamento criados na década de 1950 para a força aérea dos EUA e da Nasa (National Aeronautics and Space Administration). Nesse período, os únicos consumidores dessas primeiras unidades de processamento eram os departamentos de defesa, que financiaram o desenvolvimento da incipiente indústria de microprocessadores e outras empresas, que introduziam equipamentos e dispositivos eletrônicos inacessíveis nos mercados comerciais.

Um exemplo de inovação tecnológica que trouxe novos usos dos objetos é o da tela de toque, executada na Organização Europeia para pesquisa nuclear, que criou as bases para as aplicações atuais. A passagem dos touch pads (com funções mais limitadas) para as telas multitoque significou um diferencial importante para a Apple na disputa pelo mercado do smartphone. Na Figura 1, observa-se que as principais técnicas que constituem o smartphone foram desenvolvidas e atualizadas com base em pesquisas com financiamento estatal nos EUA.

Figura 1 - Origem dos produtos populares da Apple

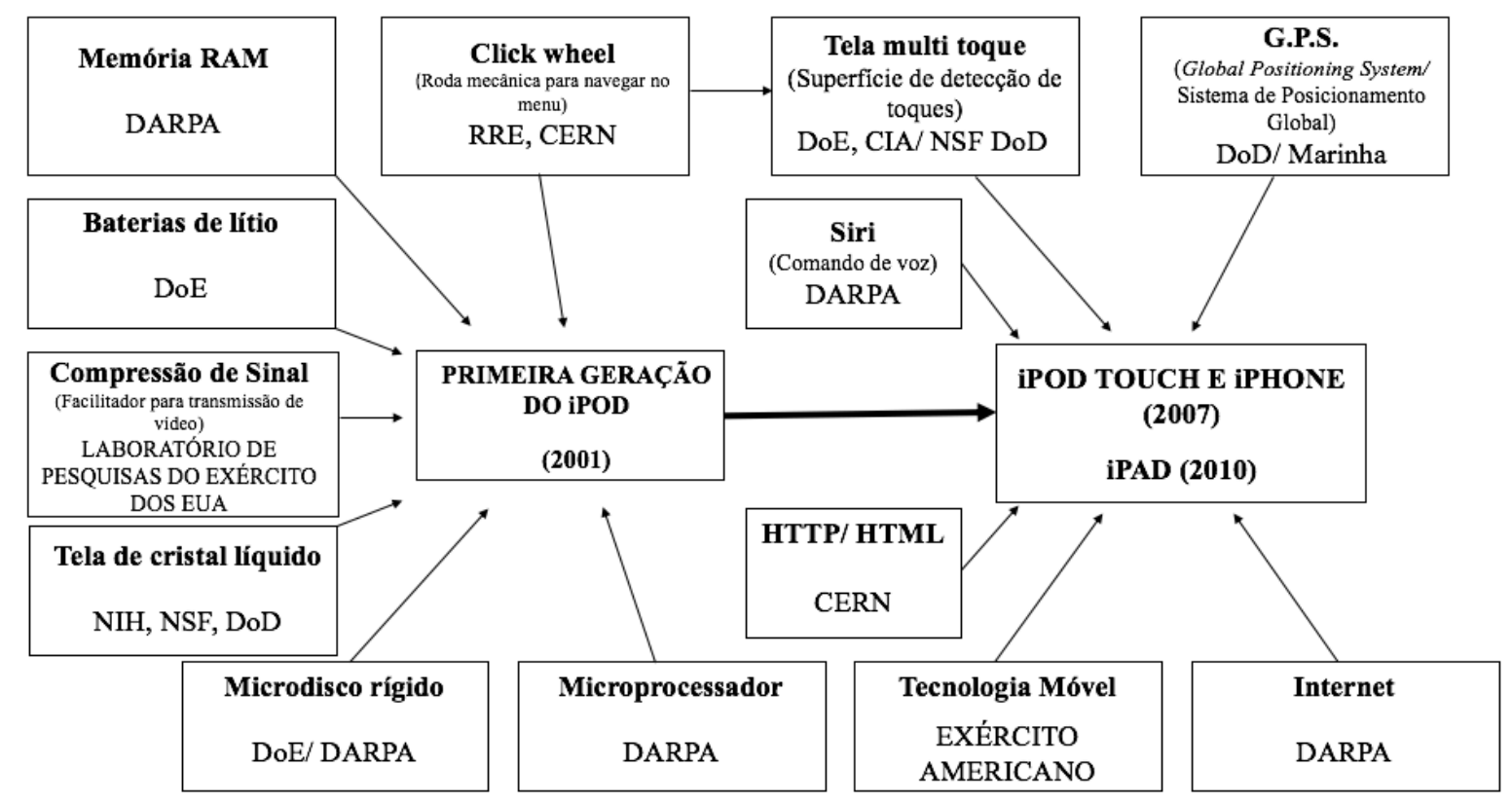

Fonte: Mazzucato (2014, p. 153).

Organização: Mait Bertollo. 
As instituições desenvolvedoras citadas na Figura 1 são:

- DARPA (Defense Advanced Research Projects Agency), Agência de Projetos de Pesquisa Avançada de Defesa dos EUA, criada em fevereiro de 1958;

- DoE (Departamento of Energy), Departamento de Energia dos EUA, criado em 1942 ;

- NIH (National Institutes of Health), Instituto Nacional de Saúde dos EUA, criado em 1870;

- NSF (National Science Foundation), Fundação Nacional de Ciências dos EUA, criada em 1950;

- DoD (Department of Defense), Departamento de Defesa dos EUA, criado em 1775;

- RRE (Royal Radar Establishment), Fundação Real de Radar, braço de pesquisas tecnológicas das forças armadas da Grã-Bretanha, fundado em 1935;

- CERN (European Organization for Nuclear Research), Organização Europeia para Pesquisa Nuclear, criada em 1954;

- CIA (Central Intelligence Agency), Agência Central de Inteligência dos EUA, criada em 1947.

A família de objetos que perfazem os produtos iOS da Apple como iPod, iPhone e iPad, largamente consumidos, é conhecida por sua tecnologia inovadora, que orientou e ainda orienta a concepção e a produção de smartphones de outras marcas como Acer, HP, Motorola, Samsung, Vodafone e Xiaomi. Assim, essas empresas resultam de décadas de apoio de instituições públicas de inovação e organizações de pesquisa com apoio financeiro do Estado, incluindo as forças armadas, em países como EUA, Inglaterra, Alemanha, França e Suíça.

\subsection{Década de 1990: expansão da rede pelo Estado e corporações no território}

A rede de telecomunicações que existia no território brasileiro até o fim dos anos 1990 era integrada pelo sistema Telebras, composto por uma empresa em cada unidade da federação que se incumbia da telefonia celular e outra empresa responsável pelas chamadas de longa distância (DDD). Essa configuração sofreu mudanças mais intensas a partir de um novo modelo de regulação implantado em 1995, cuja emenda constitucional tornou flexível o monopólio do Estado nas telecomunicações. 
Entre 1972 e 1994, os acessos à rede de telefonia aumentaram de 1,4 milhão para 13 milhões, e parte do processo de expansão era custeado pelo próprio assinante: em 1995, a instalação de um telefone custava cerca de $\mathrm{R} \$ 1.117,00,{ }^{11}$ que podiam ser parcelados em até 12 prestações, e havia uma fila de espera para receber o telefone e ações da Telebrás, como mostra Cerasoli (2000, p. 138):

$\mathrm{O}$ candidato era transformado em assinante, pagando assinatura de $\mathrm{R} \$ 0,44$ por mês, com franquia mensal de 90 pulsos locais (equivalentes a 360 minutos). Por pulso adicional, o assinante pagava $\mathrm{R} \$ 0,02$ a cada 4 minutos de conversação. Para subsidiar os baixos valores cobrados pelo serviço local, a Telebrás e suas empresas usavam as altas tarifas cobradas nos serviços interurbanos nacionais e internacionais de telefonia e nos serviços de comunicação de dados (locais ou interurbanos). Era prática bastante freqüente os assinantes venderem suas ações por valor superior ao que havia sido pago e passarem a usufruir as tarifas subsidiadas do serviço local. $\mathrm{O}$ universo de assinantes do Sistema Telebrás era composto quase totalmente pelas classes A, B e C, cuja renda média mensal era igual ou superior a $\mathrm{R} \$ 1$ mil. A classe $\mathrm{D}$ era quase um traço no cômputo dos terminais, e o atendimento à classe $\mathrm{E}$ simplesmente não existia.

Só determinadas classes de renda tinham acesso ao serviço, mas o custo, que se convertia em subsídio para manter as tarifas locais num valor inferior ao do mercado, era dividido entre toda a população.

O número de localidades atendidas passou de 2,2 mil, em 1972, para 17,5 mil, em 1994. Nesse período, a estrutura cresceu 6,5 vezes - e dez vezes mais que o da população brasileira e seis vezes mais que o Produto Interno Bruto (PIB). No entanto, o crescimento do tráfego local foi de $1.300 \%$ e o tráfego interurbano chegou a $1.900 \%$. A demanda reprimida, estimada em 25 milhões de terminais, era muito superior à planta, de 14 milhões de acesso em julho de 1998. Para agravar esse quadro, a densidade telefônica do Brasil era inferior à do México $(9,9 \%)$, à do Chile $(12,9 \%)$ e à da Argentina $(13,9 \%$ em uma operadora e 17,4\% em outra). No início de 1995, 16\% das famílias brasileiras tinham $81 \%$ do total de terminais em serviço (CERASOLI, 2000, p. 139).

\subsubsection{O evento da privatização das redes e uma nova organização do sistema}

Em 1995, um importante evento normativo que rompeu o monopólio estatal dos serviços de telecomunicações e permitiu a entrada de capitais privados no setor das comunicações foi a Emenda Constitucional n. 8, que alterou o inciso XI do artigo 21 da Constituição. A Lei n. 9.295, de 19 de julho de 1996, ampliou a abertura desse sistema para

\footnotetext{
${ }^{11}$ Equivalentes a aproximadamente US\$ 32.00.
} 
uso e administração de empresas privadas e instituiu critérios para a concessão ao setor privado de "serviços restritos e de elevado valor adicionado ainda não explorados, entre os quais se incluem a banda $B$ de telefonia celular, serviços via satélite, trunking ${ }^{12}$, paging ${ }^{13}$ e outros que possibilitam a constituição de redes corporativas" (ANATEL, 2017a).

Algumas das normas que garantiram tal abertura tiveram como base a Lei Geral das Telecomunicações n. 9.472, de 16 de julho de 1997, que estabeleceu um novo modelo institucional designando e difundindo a função da Anatel e o novo padrão tarifário do plano de outorgas, concessões e diretrizes para a venda de empresas estatais. A Anatel foi equipada para prover serviço telefônico fixo comutado para que se pudesse fiscalizar, outorgar e regulamentar o setor. Esses instrumentos eram os contratos de concessão e os regulamentos de interconexão e remuneração de redes como o Plano Geral de Outorga (PGO), o Plano de Metas de Universalização (PGMU) e o Plano Geral de Metas de Qualidade (PGMQ).

O PGO recortou o país em quatro áreas fundadas no modelo de prestação dos serviços telefônicos fixos, repartidos entre três operadoras regionais e uma nacional, garantindo às operadoras de prestação local de serviços sem concorrência até dezembro de 2003, quando foram liberadas para prestar todos os serviços relativos às telecomunicações. O PGMU determinou os compromissos das concessionárias por certo período, e o cumprimento dessas determinações condicionaria sua existência como prestadoras de serviço; na sua impossibilidade, o governo deveria assumi-los. Deliberava ainda o cumprimento dos serviços das operadoras num prazo predeterminado, relativo a reparos ou instalação (ANATEL, 2008).

O evento da privatização ainda qualificou o que se entende por rede de telecomunicações e por internet, sendo esta última interpretada, a partir de então, como um serviço de valor agregado, por ser um conjunto de protocolos que usa essas estruturas, porém com intenção de adequá-la como um novo tipo telefonia, para ser subordinada aos interesses de oligopólios.

A legislação que gere as telecomunicações fixou os limites entre os serviços de telecomunicações, que demandam obtenção de outorga e regulação desse setor e os serviços

\footnotetext{
12 Trunking significa "sistema de tronco" e designa o compartilhamento de um pequeno número de vias de comunicação entre um grande número de usuários de telefone. Esse sistema distribui com eficiência as mensagens de tráfego entre os canais disponíveis, reduz o tempo de espera do canal e tem capacidade de gerenciar chamadas sem intervenção do usuário.

13 O paging é o serviço de transmissão de mensagens escritas por ondas de rádio de uma central para aparelhos eletrônicos chamados pagers, uma versão moderna dos bips.
} 
de valor adicionado (SVA), que dispensam outorga e não são sujeitos à regulação de telecomunicações.

Por meio da Lei Geral de Telecomunicações (Lei No 9.472, de 16 de julho de 1997) ${ }^{14}$, foi estabelecido que os serviços de telecomunicações são aqueles em que possibilitam a “transmissão, emissão ou recepção, por fio, radioeletricidade, meios ópticos ou qualquer outro processo eletromagnético, de símbolos, caracteres, sinais, escritos, imagens, sons ou informações de qualquer natureza" (artigo 60).

Por sua vez, o SVA foi definido como "atividade que acrescenta, a um serviço de telecomunicações que lhe dá suporte e com o qual não se confunde, novas utilidades relacionadas ao acesso, armazenamento, apresentação, movimentação ou recuperação de informações" (artigo 61). A legislação ainda esclarece que o SVA não é considerado um serviço de telecomunicações e que o seu provedor é classificado como usuário.

Nessa perspectiva, as mudanças normativas compreendem as faces complementares da mobilidade que consumam a circulação e a comunicação. Esses dois âmbitos são parte das estratégias de dominação de superfícies e pontos por meio da gestão e do controle das distâncias pelos agentes hegemônicos (RAFFESTIN, 1993). A circulação se trata de transferência de seres e bens lato sensu e a comunicação se refere à transferência da informação, considerando que em todo transporte há circulação e comunicação simultaneamente, como assevera Raffestin (1993).

O movimento da informação comanda a mobilidade dos seres e das coisas, visto que as sociedades com forte domínio territorial são caracterizadas por fluxos consideráveis de informação e necessitam de enormes quantidades de energia, onde a informação deve se renovar rapidamente para dar coerência ao sistema. As redes de circulação e as redes de comunicação se compenetram, se articulam e interagem, criando interfaces entre circulação e comunicação que dão ao poder uma trama específica.

O desenvolvimento das técnicas de informação e comunicação e as normatizações inerentes permitem novas maneiras de gerenciamento e tributação desse setor, dando mais fluidez à circulação e ensejando a intensificação de coleta e processamento de informações e as funções de seu gerenciamento.

14 A Lei Geral das Telecomunicações $N^{\circ}$ 9.472, de 16 de julho de 1997 está disponível em http://www.planalto.gov.br/ccivil_03/LEIS/L9472.htm 
A partir desse período, a quase totalidade dos indivíduos fica "capturado" por uma rede de comunicação pois, para Raffestin (1993), as redes que interessam à comunicação de massa e à comunicação interpessoal atendem a uma estrutura formal que constituem instrumentos de poder controlados que envolvem a população numa trama informacional que as determina em relação às estratégias das organizações, cuja ameaça é a possibilidade, para aqueles que comandam esses meios, da difusão de informações cujo caráter impactante pode criar comportamentos condicionados.

Esse novo marco regulatório ainda vigora e consiste fundamentalmente na definição dos princípios que regulam os serviços de comunicação, os deveres do poder público e os direitos dos usuários, além da criação da Anatel como órgão regulador de todo o sistema, com a função também de organizar os serviços de telecomunicações quanto à abrangência de interesse e regime de exploração e reestruturação e privatização das companhias do Estado, estabelecendo as diretrizes para o novo modelo e para a venda das empresas estatais (NOVAES, 2000).

As 32 estatais que compunham o sistema brasileiro de telecomunicações foram agrupadas em quatro novas holdings, com áreas delimitadas para a prestação de serviços, e, para cada região controlada pela iniciativa privada, a Anatel expediu licenças-espelho ${ }^{15}$ visando garantir que houvesse concorrência entre duas operadoras privadas, como previa a Lei Geral de Telecomunicações. O Quadro 1 mostra a configuração concorrencial do setor de telecomunicações a partir de 1998, com as respectivas segmentações de áreas de abrangência:

Quadro 1 - Telefonia fixa pós-privatização, Brasil, 2000

\begin{tabular}{|c|c|c|c|}
\hline Holding & Operadora & Região de abrangência & Espelho \\
\hline Tele Norte-Leste & Telemar & $\begin{array}{l}\mathrm{AL}, \mathrm{AM}, \mathrm{AP}, \mathrm{BA}, \mathrm{CE}, \mathrm{ES}, \mathrm{MG}, \mathrm{PA}, \\
\text { PB, PE, PI, RJ, RN, RR, SE }\end{array}$ & Vésper \\
\hline Tele Centro-sul & Brasil Telecom & $\begin{array}{l}\text { AC, DF, GO, MS, MT, PR, RO, RS, } \\
\text { SC, TO }\end{array}$ & GVT \\
\hline Telesp & Telefônica & SP & Vésper \\
\hline Embratel & Embratel & ligações nacionais e internacionais & Intelig \\
\hline
\end{tabular}

Fonte: Novaes (2000).

\footnotetext{
15 As "licenças-espelho" expedidas pela Anatel entre 1999 e 2000 sugeriam que essas empresas reunissem um conjunto de características em seu padrão organizacional na forma de gerir a força de trabalho, sob modelos enxutos e flexíveis, com formas diferenciadas de gestão da força de trabalho via terceirização, denominando-as "empresas espelho".
} 
$\mathrm{Na}$ área onde atuava a Tele Centro-Sul, a legislação criou a licença-espelho para a Global Village Telecom (GVT), de capital privado, criada em 1999, que construiu toda a infraestrutura básica de linhas e redes com cabos de fibra ótica, pois não tinha um elementochave encontrado pelas concessionárias estatais, que era toda a infraestrutura implementada durante os marcos regulatórios anteriores.

Assim, a GVT se consolidou como uma das principais operadoras do setor nacional de telecomunicações, prestando serviços em telefonia fixa, internet e transferência de dados, fundindo-se com a Telefónica de España, controladora espanhola da concessionária responsável pelas telecomunicações no estado de São Paulo, e a Vivendi, grupo francês que atua no ramo da animação digital e das telecomunicações. Na década de 1990, além do crescimento em participação no mercado de telecomunicações, a GVT conquistou centralidade na disputa comercial para a aquisição de suas ações por companhias multinacionais.

Entre 1998 e 1999, a Telebras se reorganizou e foi privatizada, com a introdução de concorrência na rede básica; em conjunto com essas medidas, foi estabelecido também o Programa de Recuperação e Ampliação do Sistema de Telecomunicações e do Sistema Postal (Paste). Antes dessa mudança que conduziu à privatização da Telebras, suas 28 subsidiárias funcionavam conjuntamente, formando o sistema Telebras. Ao conceder diversas áreas do território a empresas que concorriam entre si, interconectaram-se as redes de diversas empresas e se compartilharam redes técnicas. Assim, inaugurou-se um período em que as empresas públicas deixavam de ser protagonistas na atuação nacional, na contrapartida do baixo retorno de investimentos em lugares menos favorecidos economicamente e com infraestruturas menos densas, já que, nesse momento, as empresas investiriam nos lugares que podiam oferecer mais rentabilidade e retorno econômico.

Diferentemente do que se obteve na privatização, com distribuição das concessões no território para a concorrência entre empresas de telefonia numa mesma área permitindo que o próprio mercado regulasse as tarifas, não houve exatamente uma competição, sobretudo nas empresas de telefonia fixa: as originárias do sistema Telebras continuaram com quase todos os clientes, consolidando um monopólio de empresas privadas nas áreas onde atuavam.

As 28 subsidiárias foram agrupadas em empresas de telefonia celular e fixa. As de telefonia celular foram criadas em banda A, sendo nove empresas que se dividiram em 10 
áreas de atividades, dada as fusões das que antes eram operadas pelo sistema Telebras. A partir dessa mudança, essas empresas passaram a competir sob novas normas, com a banda B, que entrou em operação em 1997, além de operar nas mesmas áreas antes cobertas pelas integrantes do sistema Telebras quando de seu desmembramento.

O termo banda indica a capacidade de dados recebidos e enviados por um aparelho celular e designa a faixa de frequência ${ }^{16}$ de determinado sinal de transmissão. Como esses aparelhos funcionam a partir de ondas eletromagnéticas (como os rádios), essas ondas operam em frequências determinadas.

Na telefonia celular, a banda identifica a faixa de frequência utilizada pela operadora e, até 1997, os serviços prestados pela Telebras (com uma subsidiária por unidade da federação) ocupavam a metade dos canais de frequência para telefonia celular, de 800 a 900 megahertz. Essa frequência foi chamada de banda $A$.

Após a privatização das concessões para a telefonia celular privada em 1997, o território passa a abrigar duas operadoras por área, a estatal pela banda A e a operadora privada pela banda $\mathrm{B}$, com o uso exato da frequência de 850 megahertz.

Esse serviço passou a ser prestado por duas operadoras privadas em cada área, e o governo abriu uma outra faixa de frequência, a banda $\mathrm{C}$, com frequência de 1,9 gigahertz, para ser usada por novas operadoras no mercado da telefonia celular.

Desde então, a definição das faixas vem gerando uma disputa entre os fabricantes internacionais de equipamentos de infraestrutura, bem como conflitos para o uso dessa ou daquela frequência de onda entre as operadoras. No Capítulo 2, discute-se a configuração das faixas de frequência como elementos do sistema de objetos técnicos de conexão à internet.

Os territórios passaram a ser base da atuação das empresas espelho, que são novas empresas que começam a competir com aquelas que integravam o sistema Telebras. As subsidiárias da Telebras para telefonia fixa foram agrupadas entre a Tele

\footnotetext{
${ }^{16}$ As faixas de frequência são propriedades físicas do planeta que são capazes de transportar sinais na forma de ondas eletromagnéticas. Os diferentes tipos de frequência foram divididos por suas características dentro do espectro eletromagnético desde as baixas até as altas frequências. O espectro eletromagnético é a distribuição das ondas eletromagnéticas, visíveis e não visíveis, de acordo com a frequência e o comprimento de onda característico de cada radiação. Elas podem ter vários fins: telecomunicações, comunicação aérea, civil e militar, ambulâncias, telefones sem fio, aparelhos de controle remoto, controles de segurança e demais técnicas que podem ter sinais transportados via frequências. A telefonia, as emissoras de rádio e de televisão e os sistemas de satélite também têm sua faixa de frequência reservada dentro do espectro.
} 
Norte/Nordeste/Leste (Telemar), a Tele-Centro-sul (Brasil Telecom) e a Telesp (Telefônica), tendo sido atribuída a cada qual uma área de atuação.

Como um serviço misto, e telefonia fixa tinha tarifas controladas pela Anatel, chamadas de concessionárias, e outras que prestam serviços privados, cuja tarifa é regulada pelo mercado. Estas últimas são chamadas de espelho.

As concessionárias são Telefônica, Brasil Telecom, Oi, Sercomtel, CTBC e Embratel, que têm concessão para operar o serviço até 2025.

As empresas espelho atuam nas mesmas áreas das concessionárias, mas sem a regulação da tarifa e sem certas obrigações. Enquanto as concessionárias herdaram as redes da Telebras, as espelho teriam que construir e implantar sua própria infraestrutura, como foi o caso da Vésper (comprada depois pela Embratel), da Intelig e da GVT.

Para atuar como empresa espelho, era necessária uma autorização da Anatel. Por exemplo, a empresa TIM tem licença para oferecer serviços de telefonia fixa como empresa espelho.

Assim, há uma adequação normativa do setor de telecomunicações para acompanhar as mudanças econômicas e tecnológicas das empresas, o que implicou uma nova regulamentação e um novo arcabouço jurídico-institucional. A lógica do acesso à telecomunicação a ser oferecido pelo Estado por meio de políticas públicas de acesso à comunicação passou a ser a lógica de serviços privados, prioritariamente voltados ao atendimento de demandas empresariais e conduzido pelas leis do mercado.

A partir do início da década de 1990, a reestruturação do setor de telecomunicações em função das privatizações implicou uma crescente racionalização e especialização das companhias, que organizaram a topologia das redes sob a ótica da estrutura corporativa. Para responder às demandas de fluidez e velocidade de comunicação, impulsionou-se a constituição de uma rede entre as várias empresas, com um novo conjunto de inovações organizacionais e de ações sobre o território. 


\subsubsection{Inovação das redes técnicas na década de 1990}

Para a crescente demanda de transmissão de grandes quantidades de dados nesse período em que os meios de comunicação se encaminhavam para o formato digital, a rede de fibra ótica era a técnica mais eficiente para uso da internet e para complementar outras infraestruturas como satélites, sinais de micro-ondas e de rádio, e sua implementação e presença é profundamente relacionada com as características do território.

No Brasil, as fibras óticas começam a ser implantadas a partir de 1994, sendo a Embratel a detentora de rede de transmissão de dados e responsável pela conexão das regiões, pela transmissão de dados e pela telefonia de longa distância. Após a privatização, com as novas regulamentações do setor de telecomunicação e várias empresas competindo entre si, se implementou uma rede de fibra ótica própria para interconectar os clientes e consolidar uma infraestrutura como plano de atuação em todo o país, dada a grande demanda por comunicação nessa extensão territorial.

Outra modalidade de serviço de telecomunicação abriu a possibilidade de atividade de novas empresas com a Lei Mínima de Telecomunicações, que autoriza e estabelece critérios para a prestação de serviços de rede especializada que usam as redes de fibra ótica para transmitir dados e são construídas e difundidas em áreas específicas de interesse dessas empresas. Esses são serviços corporativos que formam as redes onde é possível operar na transmissão de mensagens e dados em alta velocidade, formar redes de computadores, realizar comércio eletrônico, realizar telemedicina (operações, exames e diagnósticos a distância), integrar e difundir informações em bancos de dados, educação a distância e serviços de segurança por backup, com armazenamento e recuperação de dados e sistemas etc.

As disparidades da implementação e do acesso às redes de comunicação no território brasileiro podem ser ilustradas pela densidade dos sistemas técnicos presentes na cidade de São Paulo, em determinadas áreas por onde passam as redes de comunicação de alta capacidade e de longa distância, nacionais e internacionais. Todas as empresas concessionárias de telecomunicação realizam preferencialmente ligações entre as cidades de São Paulo, Rio de Janeiro e Belo Horizonte. As outras capitais são conectadas segundo interesses das empresas e proximidade das densidades técnicas presentes em São Paulo, como Porto Alegre, Curitiba e Florianópolis, entre outras. 
Ressalta-se que a política espacial de implementação de redes no fim da década de 1990 e começo dos anos 2000 foi orientada pela lógica dos Eixos Nacionais de Integração e Desenvolvimento (ENID), implementados durante a presidência de Fernando Henrique Cardoso (1995-2002), que considerava as redes de transporte prioritárias para o desenvolvimento e a integração regional. Aqui, é possível apontar um viés sansimonista de determinismo tecnológico, desconsiderando a rede como construção social, isto é, os indivíduos, grupos, corporações e instituições produzem estratégias e se constituem em rede: ela então não é o sujeito da ação, mas manifesta e determina sua escala. Destacamos que as escalas são construídas em processos que são divergentes e geram atritos - por isso, são, ao mesmo tempo, objetos e arenas de conflitos:

Desde o início, assumiu-se uma visão bipartida do território, que emanava da ambiguidade consciente estabelecida entre os conceitos "eixo" e "espaço" [...]. Quando se discutia a questão dos projetos de infraestrutura de transporte, se estava no domínio autêntico dos "eixos", que se bastavam a si próprios como forma espacial do quadro analítico que se queria delinear. Quando se pensava nos projetos de desenvolvimento social e informação e conhecimento, [...] os estreitos referenciais contidos na porção delimitada para os "eixos" não eram suficientes, restando adotar uma forma espacial mais ampla e territorialmente mais abrangente, definida no "relatório inicial" como "área de influência dos eixos" ou "região complementar" (GALVÃO; BRANDÃO, 2003, p. 197).

Logo, o resultado foi a implementação de uma eficaz rede logística para escoar a produção agrícola, concretizando a tradicional topologia extravertida do território nacional que integra cada eixo aos mercados internacionais de commodities (GALVÃO; BRANDÃO, 2003; FREDERICO; CASTILLO, 2003), fortalecendo o discurso político da promessa do desenvolvimento.

A implementação de redes técnicas de telecomunicações no território nacional segue a lógica de estabelecimento e uso em grandes centros e no litoral, que são áreas de maior densidade populacional e de redes e, portanto, de onde parte a expansão de novas técnicas. Assim que se banalizam e diminui o preço de implantação e uso, elas vão sendo incorporadas e capilarizadas em direção ao interior.

Nos lugares com menos sistemas e infraestruturas públicas como redes de telecomunicação, o resultado desse processo é um uso mais corporativo, por empresas que têm recursos para cobrir os custos dessa implementação, como de um canal via satélite, por exemplo. 
A distribuição desigual das redes de telecomunicação no território nacional, das ERB e das fibras óticas, é ilustrada por sua presença massiva nas três maiores capitais - São Paulo, Rio de Janeiro e Belo Horizonte -, que têm também o maior número de interligações de redes entre si. Nessas cidades, há redes de todas as corporações proprietárias de redes de fibra ótica, que podem se estender de acordo com os interesses de cada empresa, mas sempre estão presentes no "triângulo de cristal" formado por essas cidades, cuja densidade e sobreposição de redes oferece diversos tipos de serviços de telecomunicação, cenário muito diferente de outras cidades e regiões brasileiras.

A implementação de redes e o aumento de sua densidade em determinados lugares reafirmam as atividades terciárias, sobretudo onde tradicionalmente já há maciços investimentos em infraestrutura como em alguns pontos de cada cidade. Em São Paulo, por exemplo, em bairros como Campos Elíseos, Santa Ifigênia, Vila Buarque e Higienópolis, que desde sua construção e organização serviram de residência à elite paulistana que se mudava do centro velho. Com o passar do tempo, outros lugares passaram a ser valorizados e ocupados por atividades comerciais e setores mais ativos da economia, como os arredores das avenidas Paulista, Faria Lima e Antônio Carlos Berrini e centros empresariais da cidade, reiterando numa escala pequena as disparidades verificadas em nível nacional.

A implementação de redes técnicas de telecomunicações como cabos de fibra ótica usa infraestruturas já existentes nessas áreas, o que favorece as corporações pela facilidade de conexão com outros pontos do país e do mundo. A fibra ótica surgiu como elemento de revitalização de áreas degradadas na cidade de São Paulo para investimentos imobiliários e em infraestrutura e serviços no centro da cidade no fim da década de 1990, equipando e valorizando determinados pontos com serviços de transporte, energia elétrica e telecomunicações, ligando determinados pontos da metrópole à economia, à política e à cultura globais para ser utilizados como valor ao se venderem.

As novas infraestruturas de telecomunicações foram implantadas nas cidades por diversas empresas privadas, como foi o caso das fibras ópticas que usaram infraestruturas de redes preexistentes. Onde se sobrepõe diversos tipos de rede, é mais fácil e rápido implantar e adaptar redes de fibra ótica não só sobre infraestruturas de telecomunicações, mas também de qualquer outro tipo de passagem de cabos; em caso contrário, haveria obstáculos físicos ou incompatibilidades da rede existente com a rede a ser implantada. 
Para o uso de postes de energia elétrica para instalação de cabos de fibra ótica, há problemas como a distância entre os postes e o risco de a corrente elétrica causar interferência na rede de telecomunicação que os compartilha. No caso de cabos instalados sob o solo, a fibra ótica não transmite corrente elétrica, e os cabos podem ter diâmetro menor.

A privatização do setor de telecomunicações no Brasil na década de 1990 estimulou a implementação de infraestruturas no território mantendo a lógica segundo a qual os equipamentos que proporcionavam mais fluidez e tinham maior capacidade de transmissão de informações se situavam prioritariamente em lugares de população mais densa, mais bem servidos por diversas infraestruturas e com maior poder econômico, para um melhor retorno do investimento. O resultado foi a insuficiência de políticas governamentais para diminuir as disparidades regionais.

As propriedades técnicas das fibras óticas, que facilitam sua instalação onde já há redes instaladas, agravam as desigualdades e, ao mesmo tempo, favorecem que lugares densamente ocupados sejam mais facilmente recuperados usando-se infraestruturas passadas.

Assim, a década de 1990 foi marcada pela privatização da telefonia, que consolidou o que hoje registram os dados das corporações de telecomunicação no Brasil: o uso corporativo do território por oligopólios internacionais. Essas redes instaladas pelo Estado e depois concedidas à iniciativa privada perfazem um butim com vários tipos de rede, desde a instalação do telégrafo ligando diferentes unidades da federação ao centro político, continuando com a televisão e chegando a formar uma rede nacional de comunicação.

O período de privatização na América Latina, especialmente no Brasil, baseou-se na ideia de que os Estados não podiam bancar o processo de modernização dos aparatos de telecomunicação para garantir a universalização do sistema e no suposto sucateamento das infraestruturas técnicas alegado pelos governos, ao lado da ideia de um modelo de privatização que traria eficiência e menores preços e tarifas pela abertura para a concorrência (DIAS, 1995a).

As concessões repassaram às corporações as infraestruturas e a gestão, ainda que tais bens fossem inalienáveis. A herança da implementação dessas redes estruturadas por vários sistemas técnicos desigualmente distribuídos no território e a produção de normas que 
compõem em conjunto as telecomunicações caracterizam o atual processo de integração da sociedade:

O estado de São Paulo, em 1995, reunia 48\% dos 300 mil quilômetros de fibra óptica do Brasil. Inovação fundamental nos sistemas de engenharia, a fibra óptica estende-se, nos seus segmentos terrestres, ao longo de rodovias, ferrovias e dutos, enquanto os cabos aéreos de sua rede são solidários com as linhas de eletricidade, de São Paulo ao sul do país (SANTOS; SILVEIRA, M., 2002, p. 81).

Verifica-se a concentração de infraestrutura técnica no território pela existência de várias redes de fibra óptica interligando as cidades de São Paulo, Rio de Janeiro e Belo Horizonte, por exemplo, e as cidades que ficam nesses eixos acabam tendo um acesso privilegiado às redes (TOLEDO JR., 2003), o que reforça também a concentração de renda, uma vez que esses sistemas técnicos são fundamentos de todos os setores econômicos. Nesse triângulo, concentram-se sedes de corporações com articulação com o exterior, os maiores produtos internos brutos (PIB) do Brasil, universidades, centros de pesquisa e inovação etc. É nessa porção do território que se combinam as heranças técnicas que influenciam o uso do território.

\begin{abstract}
A revolução das telecomunicações, iniciada no Brasil dos anos 70 , foi um marco no processo de reticulação do território. Novos recortes espaciais, estruturados a partir de forças centrípetas e centrífugas, decorriam de uma nova ordem, de uma divisão territorial do trabalho em processo de realização. Do telégrafo ao telefone e ao telex, do fax e do computador ao satélite, à fibra óptica e à Internet, o desenvolvimento das telecomunicações participou vigorosamente do jogo entre separação material das atividades e unificação organizacional dos comandos (SANTOS; SILVEIRA, M., 2006, p. 73).
\end{abstract}

Sob essa herança da implementação concentrada de infraestruturas de telecomunicação no território brasileiro, observa-se no fim do século XX a produção de um sistema de técnicas, principalmente de informação, que passaram a ser o elo entre as demais, unindo-as e assegurando ao novo sistema técnico uma presença planetária. No período de globalização, quando nasce esse novo sistema de técnicas, também resultam ações que asseguram a emergência de um mercado global, responsável por processos políticos eficazes e em conformidade com a "arquitetura da globalização" (SANTOS, 1996), como a unicidade da técnica, a convergência dos momentos, a cognoscibilidade planetária e a existência de um motor único na história, representado pela mais-valia globalizada. 
Em virtude dessa conjuntura, as continuidades e descontinuidades de usos, serviços e infraestrutura das redes informacionais podem romper padrões de localização e implantar novas formas de reprodução do capital como o trabalho à distância e outras variantes da chamada economia flexível, o que reforça a importância do smartphone e de toda a família de objetos técnicos que se conectam à internet nas transformações espaciais e na estruturação de uma sociedade em rede. Essas mudanças incidem direta e indiretamente na zona rural e urbana, nas relações sociais de trabalho, nas finanças e no lazer, em todas as escalas.

Na década de 1990, a telefonia móvel celular se expandiu desde as metrópoles do Rio de Janeiro e de São Paulo até outras porções do território, a partir do momento em que diminuiu o valor das ligações e se ampliaram a rede suporte e a rede serviço, e seu uso se estendeu à classe média (CERASOLI, 2000).

Nesse período, a implementação do telefone público a cartão visava popularizar o serviço telefônico e reduzir os custos das empresas que faziam a coleta diária das fichas telefônicas. Mas o cartão telefônico era um dispositivo caro para a maioria da população, pois eles davam direito a certo número de minutos, e não mais a um ou três, como antes. Nesse mesmo momento, implantam-se fibras óticas, uma tecnologia menos exposta a interferências eletromagnéticas que o fio de cobre utilizado até então. Por fibra ótica, a transmissão de dados é mais rápida e segura, com maior capacidade de fluxo de informações, dados e voz.

Em fevereiro de 2001, já haviam sido instaladas 39,3 milhões de linhas para telefones fixos e 23,9 milhões de aparelhos de telefonia móvel celular, um aumento de 209\% daqueles e de 531\% destes, em relação a 1997, antes da privatização (TELECO, 2018).

A conexão entre redes se torna cada vez mais complexa e imbricada, em razão da concorrência entre as operadoras e enquanto a remuneração da rede está relacionada a seu uso. Nas palavras de Cerasoli (2000, p. 141):

[...] o regulamento de remuneração de redes substitui a participação da receita de tráfego mútuo, que previa a destinação de um percentual da receita para a Embratel e para a operadora que originava a chamada. Já nos anos 2000, usa-se o princípio da remuneração pelo uso da rede.

A regulação que a Lei Geral das Telecomunicações estabeleceu por intermédio da Anatel resultou na expansão de diversos serviços ligados às telecomunicações: 
No ano 2000, são 3,4 milhões de assinantes de TV por assinatura, em 1994, eram apenas 400 mil. A TV aberta e o rádio alcançam todo o país, no ano 2000, foram licenciadas mais 135 estações de radiodifusão. O número de satélites cresceu de 9, em 1994, para 14, em 2000, e o setor de telecomunicações cresceu 13,5\% em 1999 (ANATEL, 2008).

No início dos anos 2000, o conjunto de serviços oferecidos na escala das cidades ampliou o acesso à rede, principalmente nas lan houses, em numerosos pontos distribuídos na maioria das cidades brasileiras, que funcionavam em associação com lojas que oferecem serviços de fotocópia e digitalização de imagens. Destacam-se os serviços bancários para pagamento de contas, para que a população que não tinha acesso à internet, geralmente de baixa renda, pudesse acessá-la por meio dessas lojas; como essas pessoas não tinham outra possibilidade de acesso, evidenciava-se a exclusão em massa do uso da internet.

No começo dos anos 2000, a banda larga começou a ser usada a partir de uma infraestrutura que substituiu a internet discada. Esse acesso ainda mais rápido, cujas redes são propriedade de empresas, criou redes privadas com acesso à banda larga.

A capilaridade da internet se amplia numa topologia e, com o passar dos anos, alcança todos os municípios do território brasileiro. Esse fenômeno só foi possível pelo uso massificado dos novos sistemas técnicos fixos e portáteis dado pelo smartphone, que aos poucos chegou a pontos do território antes excluídos dessa e de outras redes.

\subsection{Período atual: a simultaneidade capilarizada}

O período atual é uma nova etapa do sistema de telecomunicações e de serviços de valor adicionado, em que a capilarização da internet no território brasileiro se consuma pelas redes construídas e distribuídas em períodos anteriores e pelo uso do smartphone. Essa nova configuração permite a conexão de pontos do território tradicionalmente excluídos das redes, ligando-os aos nós localizados nas capitais ou em regiões com maior densidade de infraestruturas técnicas dentro ou fora do país.

Para a implantação desse sistema de telecomunicação capilarizado, fizeram-se vultosos investimentos, atendendo aos mesmos princípios de seletividade espacial das empresas que fizeram a conexão às redes suporte e às redes serviço. 
Por meio da periodização, é possível identificar a ação dos Estados nacionais em prover seu território com infraestruturas para a realização da fluidez material e imaterial, o que atraiu o interesse das corporações. A telemática tem um papel determinante na nova organização das atividades econômicas, políticas e sociais no território, ampliando todos os tipos de fluxo e articulando redes de fluxo materiais e imateriais.

A telemática se caracteriza pela convergência da informática, que permite armazenar, organizar e processar grande quantidade de informação de maneira compacta e em grande velocidade, favorecendo a transmissão instantânea entre dispositivos em escala global de voz, texto, imagem e demais dados e configurando sistemas compostos de telefonia, satélite, cabos e fibras ópticas, computadores, softwares e smartphones.

Nesse contexto, a expansão da rede suporte ensejou também a expansão da rede serviço, como o uso generalizado do GPS para localização e para os trajetos mais eficientes a pé, de carro, de bicicleta ou de transporte público, com aplicativos como Waze e Google Maps, o uso de taxi ou Uber por aplicativos como Easy Taxi, 99Taxi ou pelo compartilhamento de casas ou apartamentos pelo Airbnb ou compartilhamento de carros por meio do Blablacar. Aí também podem ser consideradas as empresas que intermedeiam compras pela internet como o Mercado Livre e a Amazon, por exemplo.

Assim desponta o chamado "capitalismo de plataforma" (KENNEY; ZYSMAN, 2016), em que setores da economia como transporte, alimentação, habitação e outros são controlados no âmbito da demanda, da oferta e do lucro e têm como base aplicativos do smartphone. A economia do compartilhamento implica formas fragilizadas de trabalho como um reflexo do sistema atual de práticas de trabalho digital em toda a cadeia de fornecimento global (POCHMANN, 2016).

O uso do smartphone impõe uma nova lógica de informatização do território, e seu uso passa necessariamente pela ciência e pela técnica, pela instalação de novas infraestruturas que se articulam em sistemas de redes e pela política e pela economia na determinação dos pontos que são ligados aos nós e tem conexão com a internet. A capilarização desse objeto e a informatização que ele proporciona supõem o uso do território mais fortemente ligado à informação.

A relação entre informação e território pode ser compreendida a partir do Estado, que tradicionalmente implementou as redes públicas, e das corporações, que, mais intensamente 
desde as privatizações, distribuem de forma seletiva os equipamentos pelo território. $\mathrm{O}$ território brasileiro é servido de sistemas técnicos em que atuam vários agentes e que demandam mediação técnica para produzir, tratar e transmitir informações e proporcionar meios de comunicação. Esses sistemas técnicos são condicionantes do planejamento do território, do controle e da vigilância e da fluidez de mercadorias, pessoas e dados.

Quando comportam muitos sistemas técnicos, as porções do território permitem ações progressivamente precisas e racionais; ao mesmo tempo, aquelas porções pouco ou nada conectadas revelam a desigualdade da distribuição das redes. De um lado, um uso corporativo intenso e, de outro, áreas onde não existe conexão.

A partir da primeira década dos anos 2000, assiste-se a uma crescente racionalidade e concorrência para selecionar o espectro eletromagnético que será utilizado conforme a quantidade de frequências exploráveis para comunicações, sensoriamento remoto, radiofusão etc. Intensificam-se a exploração econômica e a disputa pelo uso das frequências, das quais as mais altas, por exemplo, podem abrigar mais informação dentro da mesma banda num sistema digital. Essa disputa é permanente, pois há um limite de natureza física e uma racionalização de seu uso pelo mercado em função de sua escassez.

Nesse período, os negócios "assumem, definitivamente, o padrão global, aumentando a circulação de informações no mundo e reforçando a densidade informacional em vários lugares privilegiados” (SANTOS, 1996, p. 56), e, no período técnico-científicoinformacional, que comporta variados sistemas técnicos, transcorrem debates éticos, econômicos e políticos que resultam em normas de uso.

Os meios de transmissão da informação e o ato da comunicação pelos sistemas, consumado pelo smartphone, objeto que está na ponta final dessa rede, estabelecem um tipo de relação da sociedade com o lugar, a região e o território que suscita uma correlação interescalar, num sistema que vincula as pequenas ações que ocorrem no plano local ao conjunto das demais ações, num sistema planetário.

Os diversos sistemas técnicos de integração digital permitem difundir e captar informações e possibilidades de comunicação pela mediação dos smartphones, que são elementos do período presente que revelam novas bases do espaço, cuja cognoscibilidade planetária é realidade: 
Pela primeira vez na história, é possível saber em extensão e em profundidade o que se passa na superfície da Terra. Quem conhece, e para que se conhece, é outro assunto. $\mathrm{O}$ fato é que apenas algumas poucas potências, alguns poucos grupos têm conhecimento do filme do mundo, isto é, aquilo que ocorre na face do planeta. Ao mesmo tempo em que, pela primeira vez na história do homem, os universais tornam se passíveis de empirização, o processo de totalização pode ser constatado empiricamente (SANTOS, 1999, p. 11).

O aumento da densidade informacional pelos territórios reforçada pelos smartphones, esse objeto informacional portátil e individual, gera mudanças no espaço geográfico em todas as suas escalas, desde o interior das formações socioespaciais até suas relações com o exterior. O período técnico-científico-informacional, em que a globalização dos negócios, dos fluxos e da produção encontram suporte nas telecomunicações sem fio, a superação da barreira da não contiguidade é real. Assim, podem-se efetivar a instantaneidade, a ubiquidade e a unicidade técnica pelo uso de satélites, redes de fibra ótica, ondas eletromagnéticas, antenas e estações de rádio base.

Baseados em pesquisas científicas para intensificar a geração e transmissão de informações e para a comunicação entre variados agentes, como era o caso do telefone até o desenvolvimento do smartphone, os objetos técnicos dominam hoje a vida cotidiana. A capilarização do smartphone pelo território, que expande o acesso à internet e todos os conjuntos de redes correspondentes que integram os lugares selecionados, são consequência de técnicas imbricadas que permitem ações racionalizadas e hierárquicas no território, ensejando a distribuição de diversas atividades, pessoas, fixos e fluxos.

Para apreender a capilarização das redes de telecomunicação e internet, consideram-se os aspectos naturais e a dimensão do território nacional, que impõem obstáculos técnicos à população e aos agentes hegemônicos. Contudo, as inovações tecnológicas no ramo da comunicação à distância possibilitaram uma ação irrestrita e totalizante no território para que a organização dos pontos econômica e politicamente mais vantajosos fosse dotada de intervenções corporativas e estatais. A seleção de determinados pontos a serem conectados à internet resulta numa integração parcial e tem consequências no território como um todo, inclusive nos pontos não selecionados.

A aceleração contemporânea (SANTOS, 1994) torna imperativo o uso de tecnologias da informação, materializado no objeto técnico smartphone, usado no Brasil por um amplo espectro social de classes de renda, de várias regiões e faixas etárias. A informação mediada 
pela técnica em enormes quantidades e várias qualidades é urgente e reivindica velocidade, mais disponível para os grandes agentes econômicos e políticos.

A divisão técnica e territorial do trabalho condiciona a hierarquia, o controle, o uso e a vigilância dos usuários e dos meios técnicos, especialmente do comando da informação. Assim, esses objetos destinam a determinados pontos do planeta informações que permitem ações características e estratégias econômicas e políticas as mais racionais e utilitaristas possíveis, fundamentadas em conhecimento parcial e em interesses restritos.

As diversas redes implementadas para integrar o território nacional e a unificação do mercado por meio da rede de transportes e de comunicação apontam a incompletude desse processo, que persiste até os dias atuais. A conexão por meio de cabos de telefone ou telégrafo, de radiofusão, ferrovias, rodovias, aviação e energia elétrica ultrapassou, em parte, as dificuldades da topografia dos terrenos e a distância, dada a dimensão continental do território, mas, por outro lado, a manutenção das redes é insuficiente, outra dificuldade para a integração do território.

A partir do começo dos anos 2000, a intensificação das inovações tecnológicas permitiu a potencial conexão de qualquer ponto do território aos centros de decisão por meio de objetos técnicos e informacionais como o smartphone, que é o ponto final de uma rede justaposta de cabos de fibra ótica, espectro eletromagnético, satélites de comunicação e outros equipamentos correlatos, que funcionam segundo a intencionalidade das corporações e dos Estados e governos.

Desde esse período, cresce a intermediação técnica da produção, do tratamento e da transmissão da informação, acrescida da vigilância e do condicionamento dos comportamentos, atingindo seu auge no uso banalizado e intenso de vários aplicativos e redes sociais.

A demanda crescente de fluidez exige desenvolvimento e implantação de equipamentos, redes e objetos técnicos que portam e impõem normas para garantir sua eficiência: 
A fluidez não alcançaria as consequências atuais se, ao lado das inovações técnicas, não estivessem operando novas formas de ação, a começar, paradoxalmente, pela chamada desregulação. A economia contemporânea não funciona sem um sistema de normas, adequadas aos novos sistemas de objetos e aos novos sistemas de ações, e destinadas a provê-los de um funcionamento mais preciso. Ao contrário do imaginário que a acompanha, a desregulação não suprime as normas. $\mathrm{Na}$ verdade, desregular significa multiplicar o número de normas (SANTOS, 2000b, p. 275).

As normas levam à interação entre a lógica das redes, que são configuradas e reguladas por agentes hegemônicos, e a lógica dos territórios, que é suporte dessas redes e que conduz essas verticalidades, dadas como "arenas de oposição entre o mercado - que singulariza - com as técnicas de produção, a organização da produção, a geografia da produção e a sociedade civil - que generaliza - e desse modo envolve, sem distinção, todas as pessoas" (SANTOS, 2000b, p. 259).

Também integram a dialética territorial as estruturas internas das relações dos lugares, entre agentes ligados por proximidade espacial e estruturas externas que engendram diversas escalas de organização espacial (DIAS, 2005). As incessantes inovações no desenvolvimento de novas aplicações, distribuição de conteúdo, telefonia por internet, velocidades de transmissão mais altas em rede wi-fi, roteadores mais rápidos e redes de acesso de alta velocidade tornou a rede mais transitável em termos de seus fluxos. $\mathrm{O}$ acesso residencial de banda larga à internet por intermédio de modem a cabo permitiu o desenvolvimento de novas aplicações multimídia como voz e vídeo sobre $\mathrm{IP}^{17}$ por meio do Skype e o compartilhamento de vídeo pelo Youtube em 2009, por exemplo.

Cada vez que conecta um smartphone, o usuário tem acesso a um conjunto de linhas e nós para receber ou transmitir informações e contatar pessoas que estão em outro lugar. Abrem-se possibilidades de conexão e localização acompanhando a topologia dessa rede que inclui e exclui indivíduos de determinados serviços. Quando se considera a demografia, a população, que passa de 208 milhões de habitantes (IBGE, 2018a) e é formada por uma parcela importante de jovens, torna-se atrativa como mercado para ampliação do sistema de telecomunicações e serviços de valor adicionado, ainda que pesem as disparidades de renda e as possibilidades de se consumirem os serviços disponíveis.

\footnotetext{
17 O IP é o endereço de protocolo de internet (internet protocol adress), e cada dispositivo conectado tem um, como o número que identifica um smartphone, um computador ou outro dispositivo conectado para enviar e receber dados. A maioria dos endereços IP tem quatro conjuntos de números separados por ponto.
} 


\subsection{Da expansão à capilarização das redes}

A rede de telecomunicações se disseminou pelo território de maneiras diferentes, resultando em diferentes impactos e acumulando objetos e ações no território com o passar do tempo, conforme a condição de implementação e uso, constituindo seu caráter heterogêneo. As variáveis de cada porção do território onde ela é implementada afeta o tipo e a qualidade do fluxo que a percorre, como a presença pregressa de sistemas técnicos e sua também desigual distribuição no território induzem certas configurações. A história da capilarização das redes e dos objetos técnicos em sistema apresenta:

[...] uma interação complexa com as antigas formas de controle, trata-se de um controle espacial do tipo intensivo, ou seja, altamente concentrado em algumas áreas fisicamente muito restritas, condensadores tecnológicos que tornam muito densas e estratégicas determinadas parcelas do espaço (HAESBAERT, 2004, p. 270).

Nem sempre toda a extensão das redes permite a conexão dos habitantes por onde é instalada, e pode não haver uma relação de presença de fixos e fluxos em determinado lugar e a imprescindível conexão de quem vive ali. Quando não há vínculo direto com o lugar, elas têm efeitos diferente nas áreas por onde passam e não prestam serviços - é o chamado efeito túnel (LENCIONI, 2006). Essa relação dos sistemas com o território e a permissão ou não para acessá-la e usá-la também podem gerar territórios descontínuos, quando se considera a totalidade da rede.

A possibilidade e a qualidade do acesso com velocidade e fluidez são dadas em função da localização do indivíduo e de sua capacidade de adquirir objetos conectores e pagar pelo serviço que permite sua conexão com melhor ou pior qualidade.

Redes de comunicação pretéritas como o rádio, a televisão e os jornais têm orientação unidirecional de baixa interatividade e uma hierarquia que dá prioridade à informação verticalizada, analógica, linear e centralizada, que abrange sobretudo as escalas do local ao nacional.

A televisão, quase nada interativa, ainda tem forte influência como sistema comunicacional do sistema global em economias de países de Terceiro Mundo. 
[...] a televisão assume o papel de um dos meios de difusão da informação banal dirigida ao consumo das grandes produções corporativas, constituindo o embasamento da difusão das ideologias corporativas como terminal das redes globais, dirigidas a uma fração importante da população e perpetuando uma lógica de pensamento único na cultura, na política e na economia (ANTAS JR., 2007, p. 94).

Por outro lado, as redes digitais que herdam as infraestruturas passadas têm uma essência multidirecional de alta interatividade, cujas redes complexas proporcionam um sentido horizontal e hipertextual, ${ }^{18}$ com topologia distribuída que ultrapassa fronteiras e se consolida como uma rede transnacional de redes.

O desenvolvimento de técnicas relativas à comunicação como o telégrafo, o rádio, o telefone e a televisão são a herança do atual período de inovação crescente das telecomunicações (e também outros segmentos da ciência): "o velho e o novo se combinam na produção das múltiplas relações dos objetos técnicos, no desenvolvimento desigual e combinado no espaço e na sociedade" (SANTOS, 2009, p. 112).

Ao longo do tempo, mudam as redes que constituem o espaço geográfico. Identificando as mudanças dos paradigmas técnicos e políticos no decorrer da história associadas às rugosidades ${ }^{19}$ (SANTOS, 1996) do presente, apreendem-se as diferentes etapas da constituição das redes de comunicação.

Composto por objetos, ações e normas e por híbridos dessas categorias, o território acolhe as redes que afetam os lugares com diferentes densidades técnicas, informacionais e normativas, resultando em "modernidades distintas, chamadas de concretude territorial" (SILVEIRA, M., 1997, p. 63).

Considerando que o espaço é constituído de sistemas de objetos e sistemas de ações como um conjunto indissociável (SANTOS, 1991), os objetos técnicos introduzidos e

\footnotetext{
${ }^{18}$ Hipertexto significa um texto ao qual se associam outros conjuntos de informações que podem ser acessados por hiperligações. Geralmente, são palavras destacadas no corpo do texto principal, ícones gráficos ou imagens de textos. As hiperligações conectam vários conjuntos de informações que podem desdobrar ou complementar o texto principal. Muito comum na internet, os hipertextos são uma ligação que simplifica seu uso, pois, ao serem carregados (ou clicados), são encaminhados a outra página, onde há outras informações relacionadas. A World Wide Web é um sistema de hipertextos numa escala maior e mais dispersa.

${ }^{19}$ A noção de rugosidades designa restos de uma divisão de trabalho internacional manifestada localmente por combinações particulares entre capital, técnicas e trabalho: "o espaço, portanto, é um testemunho de um momento do modo de produção pela memória do espaço construído, das coisas fixadas na paisagem criada. Assim, o espaço é uma forma durável que não se desfaz paralelamente à mudança de processos; ao contrário, alguns processos se adaptam às formas preexistentes, enquanto outros criam novas formas para se inserir dentro delas. As rugosidades são formas espaciais do passado, produzidas em momentos distintos do modo de produção e com características socioculturais específicas" (SANTOS, 1996, p. 138).
} 
organizados territorialmente são normatizados para regular o funcionamento concatenado das redes com eficiência e precisão, pois "os objetos impõem uma forma de operá-los e chamam a novas solidariedades técnicas [...] daí as normas técnicas serem substituídas por outras tão aceleradamente quando os objetos técnicos se sucedem e se tornam obsoletos" (SILVEIRA, M., 1997, p. 45).

O desenvolvimento acelerado dos objetos se baseia em seu funcionamento em família e de forma interdependente, pois eles devem ser compatíveis e padronizados. Para Debray (1994), essas são as condições para a difusão e a circulação de informações e, portanto, para a conexão de vários pontos do planeta. A imposição simultânea das normas visa a fluidez e, de certa forma, impõe uma homogeneização do funcionamento das redes.

Nesse contexto, destaca-se o papel do Estado, que contribui com as novas formas de organização, pois, como não é um mediador neutro, opera favoravelmente aos agentes hegemônicos e autoriza a expansão das redes transnacionais pelo território nacional.

Do arranjo entre comandos do Estado e do mercado, externo e interno, novo e velho (SANTOS, 1985), surgem nos lugares infinitas combinações de concretudes técnicas e normativas e, em consequência, de modernidades. No período atual, as concretudes se constroem com informações contidas nos objetos, nas ações e nas normas e disponível de várias formas nos níveis local, nacional e global. Daí as acelerações nos níveis dessa lógica:

Essa concretude edifica-se com normas que são, como os objetos, crescentemente híbridas porque sua natureza é técnica e política e, ao mesmo tempo, global, nacional e local - as normas são passíveis de ser interpretadas como um enredo de complexo significado que regula um sistema de objetos (SILVEIRA, M., 1997, p. 38).

Logo, há uma estrutura entrelaçada de objetos, ações e normas que compõe a lógica e a materialidade ligada à capilarização da informação e do smartphone no território, e as técnicas e normas globais reagem da mesma forma em todos os pontos do território. O lugar, que tem suas especificidades em razão de suas contínuas funcionalizações acumuladas, revela "uma síntese, a cada momento, das carências da totalidade e das aptidões dos lugares" (SILVEIRA, M., 1997, p. 40), em que é possível identificar as diferentes densidades no território.

As densidades técnica e informacional estão condicionadas à configuração da divisão territorial do trabalho, e as empresas instaladas no território precisam das infraestruturas 
implementadas, equipamentos, serviços e múltiplas redes técnicas para operar e para que possa haver inovações tecnológicas. Para entender a relação entre o uso do smartphone e seu impacto na organização e no uso do território, devem-se distinguir os movimentos totalizantes dessas técnicas e sua função na formação socioespacial no presente.

Os desdobramentos da divisão técnica, social e territorial do trabalho ao longo da história condicionam as relações espaciais e temporais que se tornam complexas e formam redes de relações que implicam mudanças no uso do tempo e no espaço, especialmente no plano das comunicações. Considerando o espaço geográfico como uma "acumulação desigual de tempos onde convivem simultaneamente diferentes temporalidades" (SANTOS, 2006, p. 181), o período presente é um legado de transformações antecedentes, com o desenvolvimento e a sofisticação dos objetos que ligam pontos não contíguos e com novas possibilidades de trocas econômicas e novas estratégias das empresas e do mercado.

Este período, em que se intensifica o movimento de globalização, potencializou e ampliou as relações planetárias possibilitadas pela mediação de sistemas técnicos complexos e correlacionados pela cognoscibilidade planetária, em que "o imediato foi substituído pelo imediato instantâneo, pela intermediação de objetos técnicos, e a informação ganha uma nova dimensão, tornando-se hierárquica" (CASTILLO, 1999, p. 12).

O funcionamento dos smartphones permitiu, no período técnico-cientificoinformacional, métodos de controle econômico e social em várias escalas espaciais. Das novas tecnologias da produção e da difusão da informação e comunicação, o smartphone é um dos objetos mais representativos. Ele faz parte da família das tecnologias da informação e, portanto, compõe uma rede de objetos organizados em sistemas que manifestam o período presente e estabelecem tendências, como um aglomerado de possibilidades e de concretização nos lugares, fortalecendo as relações interescalares entre o local e o global e suas mediações.

Entende-se que a escala do lugar pode ser mais ou menos obediente e permeável às lógicas hegemônicas:

Os lugares podem ser mais ou menos permeáveis às ações que chegam de fora, menos dependentes das mediações técnicas, e se constituem em área de atuação de todas as classes, grupos e interesses. O crescente uso corporativo do lugar e sua tendência, hoje, à especialização funcional com relação ao território nacional e ao mundo, são decorrência de sua posição de subtotalidade, inserida numa totalidade mais ampla, numa articulação territorial mais abrangente (CASTILLO, 1999, p. 27). 
Nos lugares, apreende-se melhor a chegada dos objetos e seus desdobramentos na dinâmica social em determinado período histórico e se considera a contiguidade um de seus fundamentos e seu papel de mediação entre região e território; o lugar é "a extensão do acontecer homogêneo ou do acontecer solidário e que se caracteriza por dois gêneros de constituição: uma é a própria configuração territorial, a outra é a norma, a organização, os regimes de regulação" (SANTOS, 1994, p. 20).

As ações hegemônicas são mais eficientes a partir do mundo unificado pela técnica. No período presente, os smartphones são, para a sociedade da informação, um tipo de transporte que precisa das vias de fibras óticas e satélites para funcionar, assim como os automóveis e as rodovias. A lógica hegemônica da informação reitera a hierarquia das relações socioeconômicas por meio da hierarquização que compõe esse sistema de redes que tende a se intensificar.

A informação e a comunicação mediadas por sistemas e objetos técnicos, mais especificamente o smartphone, estabelecem-se entre o aprimoramento do controle e da vigilância do território e as novas possibilidades de seu uso. Estados e corporações se relacionam na capilarização do uso do smartphone no território de forma ao mesmo tempo conflituosa e complementar no que tange ao conhecimento das técnicas, ao controle do uso dos objetos e das redes conectoras à internet e ao tipo de informação e comunicação que se dá no território e no lugar.

Em vários períodos da história humana, a informação foi usada como estratégia e ligada ao exercício do poder e da produção, apropriação e gestão do excedente. Hoje, ela se torna cada vez mais importante, pois faz parte dos mecanismos de competição e poder das corporações e dos Estados. A informação é um requisito imprescindível do poder, econômico e político no território e, assim, por meio da herança dos sistemas técnicos, para produzir recursos, as corporações procuram seletivamente esses fragmentos de modernização por todo o planeta, impondo aos Estados uma organização do território na escala dos lugares que determina normas que perpassam todas as escalas.

Ao mesmo tempo, há a universalização e a fluidez proporcionada pelas tecnologias de informação e comunicação no espaço e também a concentração espacial de atividades especializadas, de uma nova importância da proximidade, da necessidade das peculiaridades locais (SANTOS, 1994). Logo, o papel da informação é fundamental, mas ela deve ser 
produzida, tratada e transmitida, e aí se estabelecem o papel dos smartphones e a capilarização da informação no território.

Nesses termos, tornam-se possíveis as ações hegemônicas interescalares, pois baseiam-se em informações detalhadas, promovendo uma organização territorial proficiente para variados fins. Para o comando e o controle do território, a informação é imprescindível, e o desenvolvimento das tecnologias de telecomunicação para que ela seja transmitida com a maior fluidez e velocidade possíveis é fundamental para os capitais hegemônicos, o que torna a informação hierárquica e corporativa. Assim, essas técnicas específicas atingem públicos de lugares característicos pelas redes que incluem excluem grupos sociais:

[...] os fluxos de informação se tornaram condição necessária a todo movimento de elementos materiais e suas técnicas permitem uma amplificação da escala de atuação, solidarizando não somente os lugares mas também o tempo, numa evolução que vai do tempo muito diferenciado ao tempo pouco diferenciado até atingir o chamado tempo real - o tempo hábil da ação no período histórico atual (DIAS, 1995b, p. 45).

Logo, o smartphone, usado no Brasil por diversos estratos sociais, permite relações interescalares e que expõem as relações entre o espaço geográfico e os meios técnicos de geração e transmissão de informações nas formações socioespaciais e na escala da vida cotidiana. A instantaneidade das comunicações e da transmissão de informações possibilitada pelo cabo, por antenas satélites, fibras óticas e rádio - elimina em parte a latência do espaço nos pontos alcançados pelas redes.

Como produto das contenções técnicas, econômicas, políticas e sociais da escala planetária e nacional até a regional e local, as redes levam ordem aonde as corporações articulam o tempo de circulação em todas as escalas em que operam, buscando um ritmo, mundial ou nacional, e se beneficiam da produtividade, da circulação e das trocas.

$\mathrm{Na}$ escala do lugar, essas mesmas redes podem portar desordem, num ritmo sem precedentes, gerando exclusão social, alterando ligações de proximidade geográfica e transformando o mercado de trabalho. As redes implicam simetria e regularidade e, assim, não podem ser usadas para designar cidades, pois ainda que os nós das redes estejam em cidades e que se possam estabelecer conexões geográficas como confluência de diversos nós que se superpõem: 
[...] a cidade é maior e mais complexa que os nós das redes que dela fazem parte e, ao mesmo tempo, a cidade é menos do que as redes que a ultrapassam, e o que caracteriza algumas cidades chamadas de cidades globais é serem conexões geográficas privilegiadas, abrigando nós de redes em número em qualidade excepcionais (SOUZA, M., 1995, p. 124).

A teoria geográfica pode dar uma perspectiva material da densidade informacional por meio da análise da distribuição do smartphone no território e de diferentes dados colhidos e tratados. O grande número de usuários desse objeto em muitas porções do território mostra que ele não se restringe a grandes empresas e grandes agentes ou mesmo a usuários de classes sociais de maior renda, mas tem seu uso expandido e banalizado em quase todos os estratos da população. Os 220 milhões de smartphones ativos no Brasil em abril de 2018 (FGV, 2018) mostram sua capilarização, sobretudo nas capitais dos estados e nas regiões metropolitanas, que são os principais nós das redes urbanas, numa nova hierarquia que se estabelece com base na crescente importância da circulação e da comunicação.

A análise da distribuição dos smartphones pelo território brasileiro e as infraestruturas que apoiam o funcionamento da internet passa primeiramente por compreender a concentração dos sistemas de objetos técnicos, especialmente os mais sofisticados, concentrados em determinadas porções do território, que se consolidaram histórica e espacialmente. Esses complexos objetos técnicos e as infraestruturas correspondentes existem e funcionam segundo uma centralização de oligopólios ou monopólios de determinadas empresas em determinadas regiões ou lugares, sujeitos ao poder de decisão desses agentes, que impõem dinâmicas para que tudo funcione no seu entorno.

As tecnologias de informação e os novos objetos técnicos demandados por circunstancias históricas são acompanhados por mudanças organizacionais na sociedade e no território, implicando novas práticas espaciais. No atual período de globalização, a informação se coloca como o principal elemento unificador entre os lugares e fomentador da inovação, que propicia e é propiciada pelo nascimento de novas redes de fluxos imateriais, o que acarreta uma seletividade espacial dos investimentos (CHESNAIS, 1996), com nova divisão técnica, social e territorial do trabalho. A produção hoje é condicionada pela circulação, de acordo com o aprofundamento da divisão do trabalho, motivando a busca permanente pela fluidez territorial, que é:

A qualidade que têm os territórios nacionais de permitir uma aceleração cada vez maior dos fluxos que os estruturam, a partir da existência de uma base material [e normativa] formada por um conjunto de objetos concebidos, construídos [...] para garantir a realização dos fluxos (ARROYO, 2001, p. 122). 
O papel dos sistemas técnicos conformados por redes, fundamentais para a organização e o uso dos territórios, são parte de um contexto que envolve "a técnica e sua capacidade de criar condições sociais inéditas, de modificar a ordem econômica mundial e de transformar os territórios" (DIAS, 1995a, p. 44). Logo, a cada momento histórico, os sistemas técnicos (e sua implementação) são essenciais para a estruturação, o funcionamento e a articulação dos territórios.

O papel estruturante e transformador do território que têm as redes, principalmente nas cidades, pode ser notado já nas primeiras redes de telecomunicações por telégrafo (DUPUY, 1998) dentro das porções urbanas do território. A primeira linha instalada no Brasil foi entre o Rio de Janeiro e Petrópolis, em 1857, e, entre Brasil e Europa, foi em 1872, por meio de um cabo submarino. Da multifuncionalidade do telégrafo, no fim do século XIX, até a implementação de redes de telefonia celular, usadas comercialmente a partir de 1990, as redes de comunicações intra-urbanas se vêm ampliando exponencialmente, o que demanda um aperfeiçoamento contínuo dos equipamentos e do sistema de comunicações como um todo.

A ampliação e a capilarização se verificam em diversos setores, públicos e privados, de maneira intensa e rápida. Ressalta-se que o telefone, cujas primeiras linhas foram instaladas no Brasil em 1877, era privilégio das classes de renda mais alta e que, anos mais tarde, suas redes foram estendidas e capilarizadas pelas cidades, onde houve maior concentração dessa malha e que também atendeu, embora menos, o meio rural, visto que o atributo fundamental das redes telefônicas é a urbanidade (DUPUY, 1988).

A periodização proposta aqui buscou mostrar as antigas e as novas relações interescalares ensejadas pela capilarização dos sistemas técnicos de telecomunicação. $\mathrm{O}$ objeto que está na ponta dessa rede e que mostra sua inserção reticular no território para o uso da internet é o smartphone, que, na perspectiva da sucessão e da simultaneidade, permite compreender a distribuição dos fenômenos ao longo de um processo histórico e como essas relações resultam territorialmente no presente e que relações mantêm entre si.

A construção de uma periodização da implementação das redes e dos objetos técnicos que compõem o uso do smartphone, seu desenvolvimento e sua banalização considera que: 
[...] o recorte do tempo em períodos é necessário à história, quer seja ela considerada no sentido geral de estudo da evolução das sociedades ou no tipo particular de saber e de ensino, ou ainda no sentido de simples desenrolar do tempo. Entretanto, essa divisão não é um mero fato cronológico, mas expressa também a ideia de passagem, de ponto de viragem ou até mesmo de retração em relação à sociedade e aos valores do período precedente. Por conseguinte, os períodos têm uma significação particular (LE GOFF, 2015, p. 12).

Para Le Goff (2015), seccionar o tempo é uma ferramenta importante para entender o todo. No contexto da origem e desenvolvimento das redes de internet, a periodização e a sua divisão em etapas é um recurso que dá coerência ao complexo sistema que faz funcionar a internet, pois é constituído de camada de redes formadas por estruturas contemporâneas e antigas, como é possível observar no mapa 2 da rede telegráfica no globo no começo do século $\mathrm{XX}$, que constituem as redes pretéritas.

Nessa perspectiva, o quadro 2 sintetiza os períodos e os seus os sistemas técnicos e sistemas regulatórios pertencentes.

Quadro 2 - Sistemas técnicos e regulatórios de cada período

\begin{tabular}{|c|c|c|}
\hline Período & Sistemas técnicos & Sistemas regulatórios \\
\hline $\begin{array}{l}\text { Fim do século XIX e início do } \\
\text { século XX - formação do } \\
\text { sistema técnico }\end{array}$ & $\begin{array}{l}\text { - Telégrafo elétrico, } \\
\text { - Código Morse; } \\
\text { - Rede de telefonia em } \\
\text { cabos subterrâneos; } \\
\text { - Telefones com } \\
\text { discagem de números; } \\
\text { - Central telefônica a } \\
\text { bateria; } \\
\text { - Central automática; } \\
\text { - Primeiras } \\
\text { telefônicas; } \\
\text { - Primeiros telefones } \\
\text { públicos. }\end{array}$ & $\begin{array}{l}\text { - Criação da Companhia } \\
\text { Telefônica Brasileira - } \\
\text { CTB (1916); } \\
\text { - Participação técnica da } \\
\text { empresa canadense } \\
\text { Brazilian Traction } \\
\text { Light \& Power. }\end{array}$ \\
\hline $\begin{array}{l}\text { Pós Segunda Guerra } \mathrm{e} \\
\text { convergência da informação e } \\
\text { comunicação }\end{array}$ & 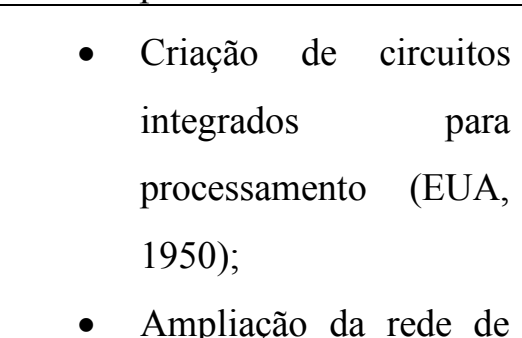 & $\begin{array}{l}\text { - } \text { Criação da Empresa } \\
\text { Brasileira } \\
\text { Telecomunicações } \\
\text { Embratel }(1965) ; \\
\text { - } \text { Criacão do Ministério }\end{array}$ \\
\hline
\end{tabular}




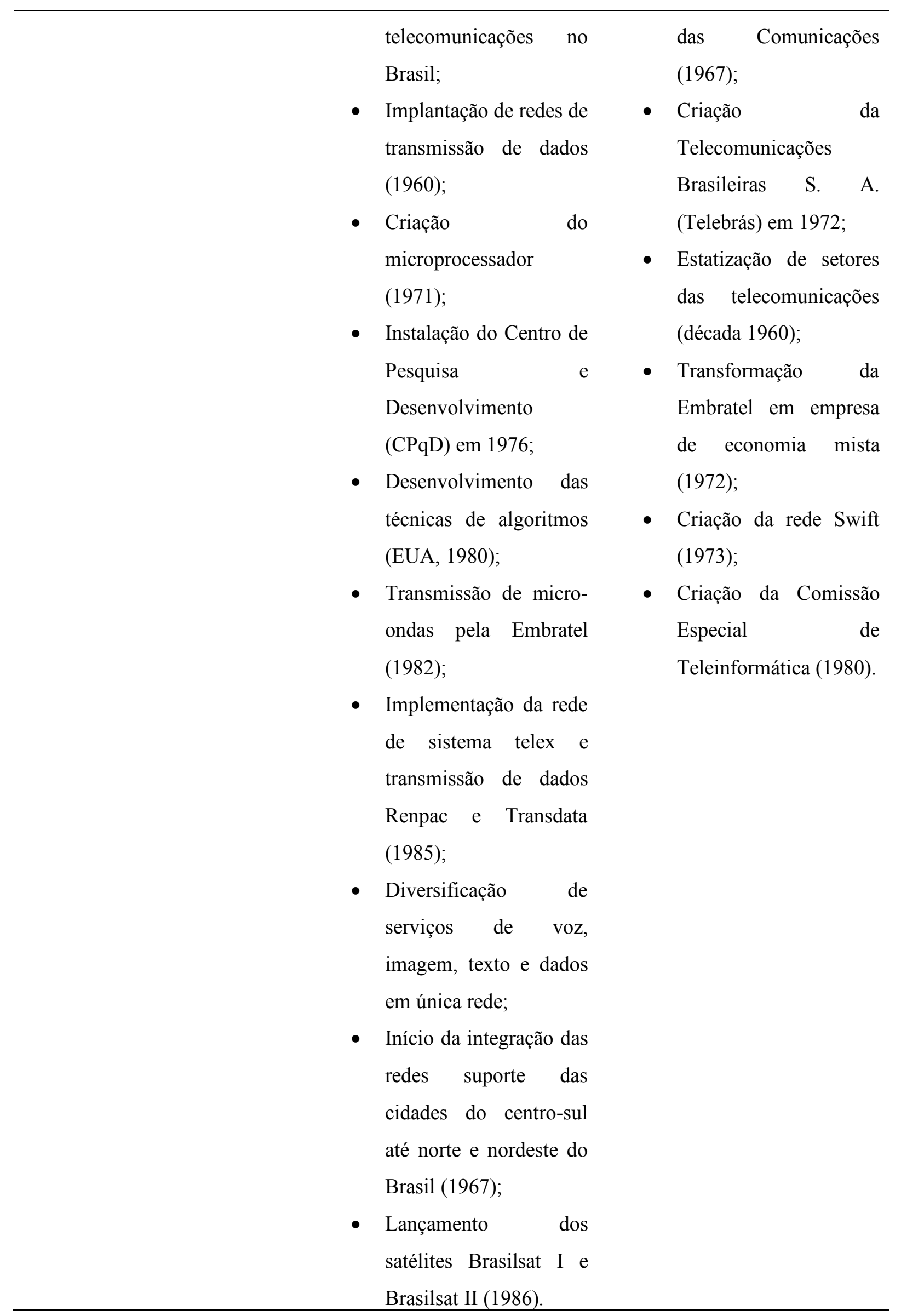




\begin{tabular}{|c|c|c|}
\hline $\begin{array}{l}\text { Década de } 1990-\text { as } \\
\text { privatizações e a expansão da } \\
\text { rede pelo Estado e corporações }\end{array}$ & $\begin{array}{l}\text { - Início da implantação } \\
\text { de fibras óticas (1994); } \\
\text { - Trunking e Paging } \\
\text { (1996); } \\
\text { - Operação da Banda B } \\
\text { (1997); } \\
\text { - Criação da Banda A } \\
\text { (1997); } \\
\text { Criação da Banda C } \\
\text { (1997). }\end{array}$ & $\begin{array}{l}\text { - Emenda Constitucional } \\
\text { n. } 8 \text { (1995); } \\
\text { - Implantação dos Eixos } \\
\text { Nacionais de Integração } \\
\text { (1995-2002); } \\
\text { - Lei n. 9.295 (1996); } \\
\text { - Lei Geral das } \\
\text { Telecomunicações n. } \\
\text { 9.472 (1997); } \\
\text { - Plano Geral de Outorga } \\
\text { (1997); } \\
\text { Plano de Metas de } \\
\text { Universalização (1997); } \\
\text { Plano Geral de Metas } \\
\text { de Qualidade (1997); } \\
\text { Licenças Espelho } \\
\text { (1998); } \quad \text { Programa de } \\
\text { Recuperação } \\
\text { Sistema } \\
\text { Telecomunicações e do } \\
\text { Sistema Postal (Paste), } \\
\text { 1999. }\end{array}$ \\
\hline $\begin{array}{l}\text { Período Atual }-2018-\text { a } \\
\text { simultaneidade capilarizada }\end{array}$ & 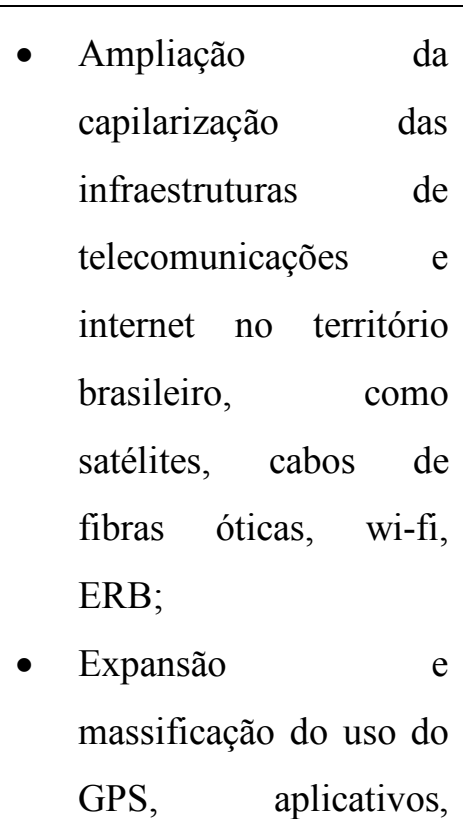 & 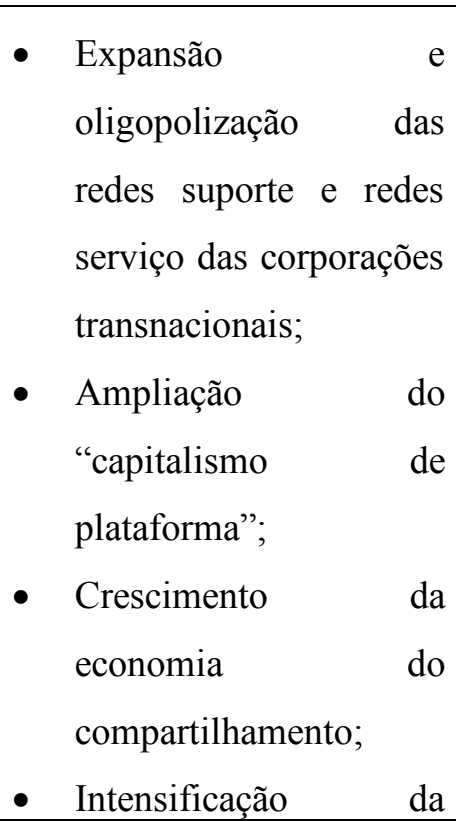 \\
\hline
\end{tabular}




\begin{tabular}{lllrr}
\hline softwares, smartphones & & exploração e disputa \\
& e novas aplicações & pelo uso das \\
& multimídia; & frequências. \\
& Crescente racionalidade & \\
& para uso do espectro \\
& eletromagnético; \\
& Essência \\
& multidirecional da \\
& interatividade e do \\
& hipertexto. & \\
\hline
\end{tabular}

Elaboração: Mait Bertollo

Assim, a periodização permite identificar as continuidades e descontinuidades numa análise espaço-temporal e, do ponto de vista do método, a hierarquização dos eventos e a delimitação de períodos estão particularmente ligados ao sistema de conceitos utilizados motivando a ênfase em acontecimentos que têm maior impacto socioespacial que outros, influenciando a estrutura da periodização.

A rede de telecomunicações é um importante recurso analítico do espaço e do território em diversas escalas, pois os fluxos de informações que as percorrem são a cada período histórico mais mutáveis e menos controláveis e condicionam, por intermédio do sistema financeiro integrado mundialmente, a organização econômica e política dos lugares, do mesmo modo que influenciam as práticas sociais. 


\title{
CAPÍTULO 2
}

\section{SISTEMAS TÉCNICOS NO TERRITÓRIO PARA USO DO SMARTPHONE E A INFORMAÇÃO CAPILARIZADA}

\begin{abstract}
Pouco nos importa que um dos mandatários fale do buraco de ozônio, que um outro represente as indústrias químicas, um quarto os eleitores, um quinto a meteorologia das regiões polares, que um outro fale em nome do Estado, pouco nos importa, contanto que eles se pronunciem todos sobre a mesma coisa, sobre este quase-objeto que criaram juntos, este objeto-discurso-natureza-sociedade cujas novas propriedades espantam a todos e cuja rede se estende de minha geladeira à Antártida passando pela química, pelo direito, pelo Estado, pela economia e pelos satélites. Os imbróglios e as redes que não possuíam um lugar e possuem agora todo o espaço. São eles que

é preciso representar, é em torno deles que se reúne, de agora em diante, o Parlamento das Coisas.
\end{abstract}

Bruno Latour, 1994

O uso da internet se popularizou no Brasil a partir de 1998, e sua infraestrutura se baseia no desenho das redes implementadas desde a década de 1960. A partir dos anos 2000, a internet começou a fazer parte do cotidiano das corporações de mídia e de informação e também dos cidadãos comuns. Quanto mais usuários se conectavam à rede, mais técnicas novas eram concebidas no plano das redes suporte e das redes serviço, intensificando esse uso e tornando-a mais acessível e instigante.

As redes interescalares e transnacionais que compõem a internet viabilizam a troca de mensagens entre indivíduos, corporações e Estados, desde que suas redes sejam capilarizadas pelos territórios e possam ultrapassar fatores restritivos como a não contiguidade, as distâncias e a topografia dos terrenos, entre outros.

A infraestrutura da internet e a atuação dos vários agentes resultam numa organização territorial que é intensificada pela capilarização das redes suporte que perfazem grandes infraestruturas como backbones, ${ }^{20}$ antenas, espectro eletromagnético, conexões wi-fi, redes $3 \mathrm{G}, 4 \mathrm{G}$ e $5 \mathrm{G}$, cabos etc. Elas são entendidas como sistemas que têm uma autonomia específica e um funcionamento concatenado; constituem o núcleo da internet e são essenciais para todas as interações propiciadas pelos smartphones por meio de sua conexão.

${ }^{20}$ Backbone é frequentemente designado como espinha dorsal da internet. É um conjunto de pontos que transportam os dados entre diversos lugares. São ligações centrais de um sistema amplo, com alta performance para interligar diferentes tipos e fluxos de dados, como voz, imagem, texto etc. Os backbones podem ser hierarquicamente divididos entre as ligações intercontinentais, que derivam nos backbones internacionais objetivado nos cabos de fibra ótica submersos nos oceanos conectando os continentes, que por sua vez resultam nos backbones nacionais. Nessa escala se encontram várias empresas que exploram o acesso à telecomunicação. O backbone é a central que liga as operadoras aos servidores externos. 
As camadas de sistemas técnicos que viabilizam uma conexão interescalar entre empresas globais proprietárias de redes suporte e rede serviço até o smartphone em qualquer ponto do território demandam uma interligação coerente entre inúmeras redes dispersas e que são conectadas, primeiramente, pela maior e mais relevante estrutura para o funcionamento planetário da internet: os backbones.

Esses imensos cabos de fibra ótica percorrem caminhos entre as redes e associam a maior parte do tráfego, aplicando maior velocidade e capacidade de transmissão ao conjunto de redes. Em geral, são instalados no assoalho de oceanos e mares por corporações de telecomunicações e se estendem por milhares de quilômetros, o que lhes confere uma abrangência planetária. Essas diversas redes de longa distância se conectam entre si e com redes locais, dando escala mundial aos fluxos de dados e impondo seu poder de penetração interescalar nos territórios.

Os inúmeros tipos de tecnologia de conexão - wi-fi, redes $2 \mathrm{G}, 3 \mathrm{G}, 4 \mathrm{G}$ e $5 \mathrm{G}$ - por meio de sinais de telefonia celular, cabos e satélites são responsáveis pelas ligações individuais, as ditas última milha. Essas tecnologias compõem as chamadas sub-redes, que ficam na ponta da internet e conectam usuários individuais que estão em lugares com maior ou menor densidade técnica ou de forma dispersa; assim, eles se conectam capilarmente a essa infraestrutura.

O backbone integra o tráfego dessas sub-redes conduzindo-o a grandes distâncias e em grande volume, dado que passa por ele toda e qualquer informação digital gerada ou destinada às sub-redes.

No período atual, as formas de organização social em rede requerem uma integração funcional de atividades dispersas, o que demanda o uso crescente da tecnologia da informação, que funciona sobre a base material da conectividade entre os nós (CASTELLS, 1999; DIAS, 1995b).

Os processos de integração dos mercados globais no período técnico científico informacional se intensificaram a partir dos anos 2000 e demandaram o estabelecimento de sistemas técnicos sofisticados para dar base aos fluxos financeiros globais para integrar informações entre países, regiões, cidades e demais lugares onde a rede pode ser capilarizada. Tais infraestruturas deram forma às redes, e aumentar sua densidade é o pressuposto para viabilizar a crescente circulação de mercadorias, informações e capitais. Esse processo 
modifica as relações de espaço e tempo condicionando práticas sociais, políticas, econômicas e culturais e reorganizando o território.

\subsection{O objeto técnico smartphone: as novas práticas sociais que transformam o território}

Tecnologia, redes e território são conceitos basilares para compreendermos a capilarização da informação no território. A tecnologia é entendida aqui como "um conjunto de conhecimentos e informações organizados, provenientes de fontes diversas como descobertas científicas e invenções, obtidos através de diferentes métodos e utilizados na produção de bens e serviços" (CORRÊA, R., 1997, p. 250). Assim, ela requer procedimentos encadeados com uma ordem e uma racionalidade que articula várias famílias de técnicas.

As técnicas podem ser entendidas como resultantes da relação entre o homem e o espaço geográfico, que "são um conjunto de meios instrumentais e sociais com os quais o homem realiza sua vida, produz e, ao mesmo tempo, cria espaço" (SANTOS, 1996, p. 25) e, portanto, produto da ação humana. Sua complexidade varia de acordo com o contexto das relações espaciais e o âmbito de seu desenvolvimento histórico. No período atual, a técnica tem propriedades aplicadas às atividades econômicas que estabelecem um ritmo a sua valorização e a sua distribuição pelos territórios, explicitando as relações em cada período, desde sua concepção, implementação e operação segundo as variáveis políticas, econômicas, sociais, culturais e espaciais que permitem ou não o seu uso.

O sistema técnico da internet comporta o transporte de informações e se inscreve no território que influencia e é influenciado pela topologia de seus pontos, nós e bifurcações. As redes que perfazem a internet são compostas e intrincadas por seu âmbito social e político e sem isso a rede é uma simples abstração (SANTOS, 1996).

A implantação da rede serviço e a consequente intensificação dos fluxos informacionais e de comunicação estrutura as escalas do território, pois "ele é o chão mais a identidade, o fundamento do trabalho, o lugar da residência, das trocas materiais e espirituais e do exercício da vida" (SANTOS, 2002, p. 10). Logo, ele também é demarcado por relações de poder e para o exercício do poder, pois é onde se projetam também o trabalho, a energia e a informação, e, por consequência, revela relações marcadas pelo poder das redes (RAFFESTIN, 1993, p. 144). 
Assim, as dinâmicas de capilarização da informação pelo uso do smartphone decorrem de políticas do Estado, de corporações e de pressões de grupos sociais, revelando que o território resulta da "interação entre múltiplas dimensões sociais, cujo sentido relacional considera o significado de enraizamento, estabilidade, limite, fronteira, fixidez, mas também as lógicas de movimento, de fluidez e de conexão" (HAESBAERT, 2002, p. 192). Logo, as redes de telecomunicação derivam de vários processos de inovação tecnológica, do desenvolvimento socioeconômico e de sua estruturação no território.

A noção de rede supõe fluxos, alianças e movimentos e não é redutível a um único agente ou a uma única rede, pois é composta de séries heterogêneas de elementos animados e inanimados, conectados e agenciados (MORAES, M., 2004). O processo de globalização da economia capitalista estabeleceu uma hierarquização de mercados que pressupõem fluidez e velocidade de informações, mercadorias e capitais, tornando ainda mais complexa a divisão territorial do trabalho. Há, portanto, uma importância estratégica e funcional das redes técnicas, que favorecem ações verticais no âmbito da economia, da organização do território e da produção.

A "informatização do território" (SANTOS, 1992) relaciona o uso dos objetos que ele abriga - como os smartphones -, com cada vez mais informações contidas em seu hardware, em seu software e em seus aplicativos. Neste período, os objetos incluem intencionalidades que atendem à crescente demanda de fluxos configurando o território.

Desde a concepção dos pontos que acolhem os sistemas técnicos da rede suporte da internet até sua implementação no território, há influências e intervenções no espaço geográfico, sobretudo o urbano, onde já existem alguma densidade de redes herdadas e média ou alta densidade populacional. As regiões com maior fluidez e distribuição de funções produtivas, principalmente nas cidades, têm uma circulação mais fluida no território. Essa característica permite maior acesso material ou imaterial e financeiro das empresas e dos indivíduos, visto que a divisão do trabalho é mais complexa, e o consumo e a produção se intensificam motivando mais movimentos e criação de riqueza, como é o caso de metrópoles e cidades médias das regiões Sudeste e Sul.

Nas zonas onde a divisão do trabalho é menos complexa e menos densa, as funções se concentram numa cidade, e as localidades que têm o mesmo papel ficam longe umas das outras, processo comum em todas as regiões, principalmente no interior do Norte e no 
Nordeste. As redes urbanas são cada vez mais heterogêneas e compostas, uma vez que tanto o campo quanto a cidade têm relações e história específicas, de acordo com suas condições econômicas, sociais, políticas e espaciais.

O papel das metrópoles como acolhedoras da implantação e distribuição das redes técnicas da internet está associado ao período atual, quando o mercado único, segmentado e articulado por corporações de telecomunicações e informação e pelo próprio Estado, comandam o território e capilarizam as ordens, tornando essas localidades "funcionalmente centrais" (SANTOS, 1992), principalmente por conta das condições de instantaneidade e simultaneidade das ações no espaço geográfico.

A simultaneidade das ações promovidas pelos sistemas de objetos técnicos inaugurou ou intensificou o funcionamento interescalar afetando a hierarquização do "tempo social e dos momentos da vida social [...] em que em cada ponto, nodal ou não, da rede urbana ou do espaço, temos tempos subalternos e diferenciados, marcados por dominâncias específicas" (SANTOS, 1996, p. 98). Assim, desponta a hierarquia das informações, cuja qualidade, valor e inserção dependem da densidade de redes técnicas de cada ponto como uma variável do sistema urbano.

Essa relação hierárquica é estabelecida pelo emissor, que controla todos os fluxos principalmente os de informações - em todos os lugares. Ao mesmo tempo, com seu poder de atração e de comando, a metrópole pode estar em todos os lugares, a partir do momento em que o espaço de fluxos e as redes estruturam o território e definem o desenho do sistema urbano. A metrópole informacional, que tem numerosos nós de redes, tem sua potência econômica e política assentada em seu poder de organizar o território por meio de vetores hegemônicos ligados à comunicação, constituindo-se como "metrópole onipresente" (SANTOS, 1992, p. 47) no desenvolvimento regional.

Seja na metrópole ou em outras regiões ou lugares, a capilarização da informação pelos smartphones é heterogênea, e as diversidades e complexidades do sistema urbano revelam as disparidades do fenômeno urbano e regional brasileiro.

Nos diferentes períodos históricos do Brasil, certos eventos tornaram o território mais permeável a novos sistemas e formas de organização, o que fez avançarem etapas com integração interna e externa desigual e teve resultados díspares da perspectiva territorial. 
Atualmente, a implantação e o uso dos objetos obedecem à lógica dos sistemas técnicos, o que aparentemente oculta a face social e humana das redes. Evidencia-se, assim, a divisão social entre os que detêm o monopólio da formulação de discursos e, portanto, se tornam dominantes, e aqueles que são excluídos desse exercício, o que intensifica e aprofunda a desigualdade. A partir do momento em que se transferem novas funções para as máquinas, representando o desenvolvimento da automação com o tratamento da informação, concretizam-se funções extremamente complexas desempenhadas por dispositivos e objetos, como é o caso do algoritmo, ferramenta mais utilizada hoje na internet.

$\mathrm{O}$ algoritmo ${ }^{21}$ trabalha com uma grande base de dados, a chamada big data, ${ }^{22}$ cujos mecanismos são dados por novas cooperações entre serviços informáticos que se conectam com novas técnicas de telecomunicação e possibilitam a criação, a circulação e o armazenamento de um gigantesco montante de informações que fazem parte da vida cotidiana e banal de vários estratos da população e em vários pontos do território.

A transmissão, organização e estocagem dessas informações virtuais estão sujeitas ao manejo de indivíduos reais, que estruturam essa gestão de forma hierárquica, e seus dirigentes operacionais seguem a lógica do valor da informação de acordo com sua capacidade de circulação. A informação perde valor de uso se for apenas acumulada e estocada como uma mercadoria "material", pois o pressuposto de sua valorização são sua livre circulação e capacidade de ser nova e economicamente útil de acordo com a amplitude do seu uso (LOJKINE, 1995). Esse movimento de circulação de informações e de troca de valores através das redes é ininterrupto e, quanto mais banal e menos substancioso seu conteúdo, mais são difundidas pela mass media:

\footnotetext{
${ }^{21}$ Algoritmo é uma sequência lógica que define instruções a serem seguidas para resolver um problema ou executar uma tarefa.

${ }^{22}$ Big data é um imenso conjunto de dados gerados, capturados, armazenados e produzidos continuamente no mundo todo. Esses dados são comercializáveis e cada vez mais valiosos e passam por processos que extraem valor desse grande acúmulo.
} 
A enorme massa de comunicação por habitante é paralela a uma corrente cada vez menor de comunicação global. Cada vez mais, somos obrigados a aceitar um produto estandardizado, inofensivo e insignificante. ${ }^{23}$ É o câncer da estreiteza e da fraqueza criativas (WIENER, 1962, p. 58).

Ressalta-se que o conceito de mass media refere-se à imprensa - rádio, televisão e novas mídias -, que faz a mediação entre informação e indivíduo. As representações são construídas por meio dos fluxos, cujo alcance varia da escala planetária até as vivências locais, que recebem uma afluência contínua de imagens, sons e palavras com conteúdo muito diversificado como notícias, textos, filmes, músicas, fotos, imagens etc. Essas informações são produzidas ou intermediadas por agentes que mobilizam recursos técnicos e informacionais. Aqueles que recebem a informação, mesmo que ela esteja dispersa, constituem as massas: os alvos amplos dos fluxos contínuos de comunicação das corporações de mass media (DUNLOP, 2010, p. 101).

Assim, as informações, com suas representações e intencionalidades, se capilarizam e atingem um grande número de indivíduos, processo no qual a simultaneidade é fundamental, na dinâmica da recepção e emissão de informações por downloads e uploads. Esse uso é díspar no território brasileiro, já que a participação nessa rede por meio de uma experiência interativa e interescalar depende da capacidade de construir redes e articulá-las, num momento em que o poder da capilarização desse sistema é produzir mais redes que se conectam e articulam a outras.

Essa produção de redes é possível em razão de sua arquitetura, que permite a existência de soluções, plataformas ou sites que exigem condições especiais de acesso: senhas, pagamentos, entrega de dados pessoais e intrusão no smartphone do usuário, com condições opacas de navegação (LÉVY, 1999) e possibilidades colaborativas, como o site Wikipedia, ou fechadas e bloqueadas para mudanças, como o Facebook.

As redes que compõem a internet têm base técnica acadêmica e militar fundada nos EUA, surgida em 1950 e motivada pelo lançamento do satélite soviético Sputinik e por outras disputas ligadas à Guerra Fria (1945-1989). Assim, a Rand Corporation criou uma rede de computadores independente de comando e controle centralizados, capaz de resistir a um eventual ataque nuclear que atingisse os centros de comando. Nasceu aí a topologia da malha como uma teia de conexões de arquitetura descentralizada com vários pontos.

${ }^{23}$ Ressalvamos que, embora se pretendam e até pareçam inofensivos, os produtos padronizados da mass media são efetivamente intencionais. 
Apesar de o propósito ter sido distribuir essa rede, há hoje uma grande concentração de fluxos em alguns sites e aplicativos como Google, Facebook, Amazon e Netflix, por exemplo.

Ao mesmo tempo em que há uma concentração de usuários em poucos sites e aplicativos comandados por corporações da informação e internet, há também um controle cibernético que acompanha os trajetos das pessoas e as ajuda nas tarefas diárias e na solução de problemas através dos smartphones e de seus aplicativos. Nesse uso, mesmo sem a permissão do usuário, os dispositivos georreferenciam, vigiam, escutam e filmam, além de ampliar o poder de comunicação e produtividade, dada sua capacidade de acessar recursos multimídia e de internet, induzindo uma sensação de comodidade.

O controle exercido pelas redes digitais condiciona e reconhece os comportamentos dos usuários armazenando e influenciando as dinâmicas cotidianas de cada um. As vidas e as condutas estão cada vez mais sob a mediação do smartphone, que também manipula dados e informações dos indivíduos, captados e usados como matéria-prima no mercado de dados pessoais.

As informações tratadas e orientadas e distribuídas entre os smartphones conduzem relações subjetivas, visto que o mercado de dados pessoais oferece às corporações elementos fundamentais para capturar a atenção dos vários segmentos sociais, o que se efetiva por determinadas estratégias:

Superar a dispersão do cotidiano, ultrapassar a concorrência das outras empresas e vencer as guerras estéticas pela produção de mundos. As tecnologias contidas nos celulares, tablets, computadores e máquinas de processar informações produzem a vida intermediada pela cibernética e vão reproduzindo o capital a partir de redes ciberviventes (LAZZARATO, 2006, p. 224).

A ação do usuário de smartphone está subordinada à entrega de seus dados para receber informações dirigidas e moduladas. Com o smartphone, o indivíduo se torna o ponto da extremidade da rede informacional que se capilariza e que está sob as normas que incidem no uso do objeto.

Considerando o espaço geográfico como um híbrido de um sistema de objetos e um sistema de ações (SANTOS, 1996), temos que os objetos são elementos da transformação social e resultantes da totalidade em movimento que a sociedade conduz: 
O conjunto de formas materiais (naturais e artificiais, articuladas ou não) que impõe resistências, oferece abrigo, expõe ao perigo, separa, unifica etc., somado a um conjunto de permissões e proibições que regula a maneira como cada porção pode ser apropriada, transformada e usada (CASTILLO, 2009, p. 18).

Os macrossistemas técnicos que perfazem a internet, entendida como um sistema global de redes interligadas, são formados por inúmeros objetos articulados. Para que se estabeleça e mantenha a conexão à rede, funções devem ser executadas continuamente, obedecendo a uma estrutura baseada no modelo criado pela International Standard Organization (ISO) para a rede de computadores conhecido como Open Systems Interconnection (OSI), ou Interconexão de Sistemas Abertos, que nasce para padronizar equipamentos produzidos por diferentes empresas, de modo que possam se comunicar e operar conjuntamente, permitindo a comunicação entre sistemas diferentes.

Assim, esse modelo também é adotado na arquitetura dos elementos e das funções da internet, padronizada de modo a identificá-los e situá-los. Curien e Dupuy (1996) organizaram e sintetizaram em sete camadas a forma como as informações percorrem a internet (Quadro 3). São elas a camada física, a de ligação, de rede, de transporte, de sessão, de apresentação e de aplicação, representando o caráter escalar desse funcionamento. O âmbito físico é a infraestrutura: cabos de fibra ótica, estações rádio base, ondas eletromagnéticas e outros equipamentos, formando a base material encadeada para que se realize a conexão. A camada ligação consiste na assistência à segurança e à qualidade de todos os seus elementos na rede, que é por onde passa uma informação da origem ao destino.

Para que haja essa fluidez, o transporte garante o movimento ponto a ponto na rede e é formado por protocolos que monitoram seu funcionamento integral. A camada de sessão é responsável pela compatibilidade dos elementos periféricos com a infraestrutura da rede e, em seguida, a de apresentação é o princípio da relação imediata com o usuário, tornando a rede acessível. A de aplicação abarca todos os produtos e serviços que sustentam o acesso à rede como sites ou aplicativos conectados à internet através do smartphone. 
Quadro 3 - As camadas no modelo Open System Interconnection (OSI)

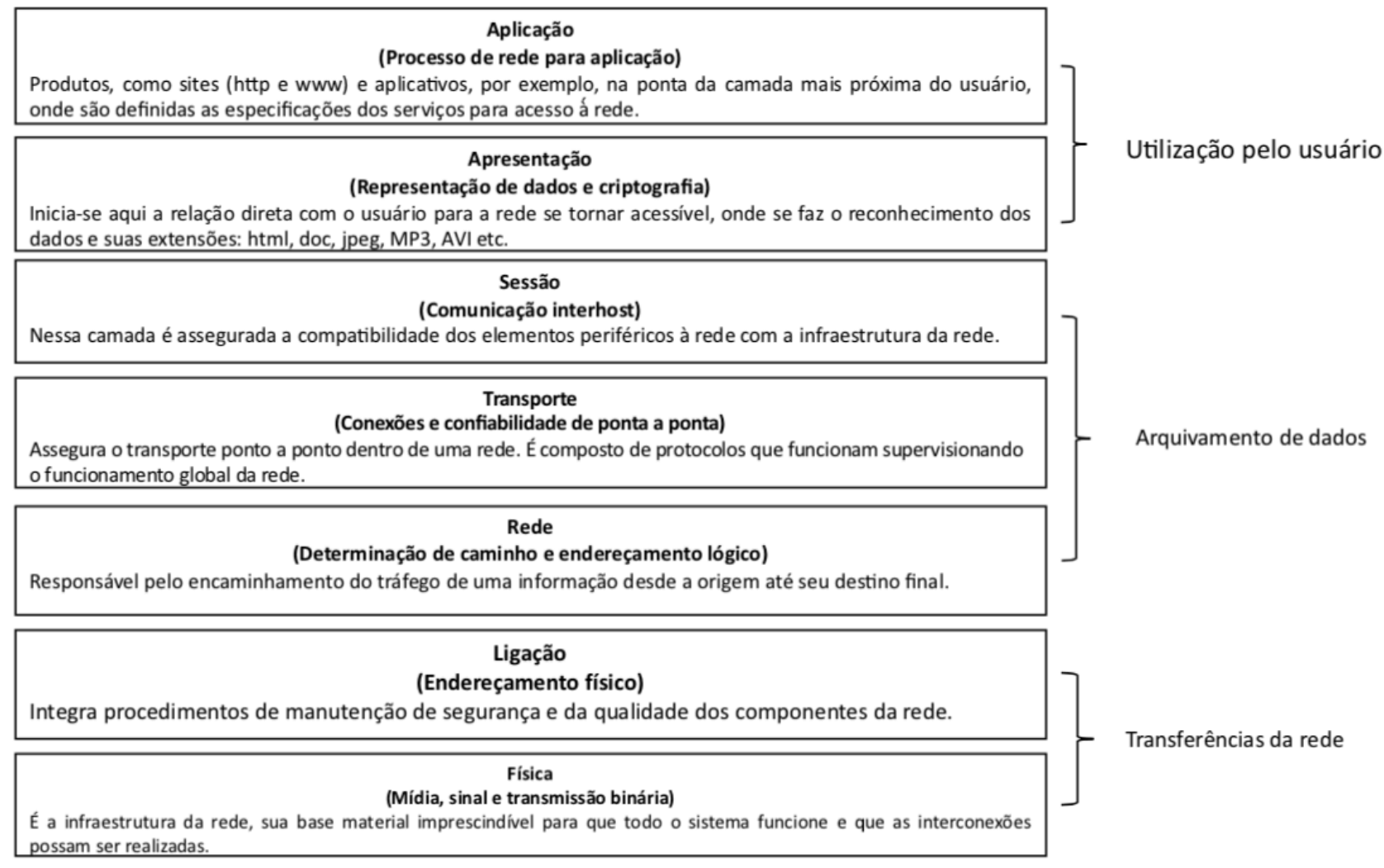

Fonte: Adaptado de Curien e Dupuy (1996, p. 17) e Gargaz (2011, p. 11).

Esse modelo simplificado ilustra a forma como as camadas se intercomunicam, são regidas por normas que asseguram seu funcionamento e regulam as ações dos usuários.

Além do modelo OSI, outra arquitetura, a chamada TCP/IP (Transmission Control Protocol/ Internet Protocol) é utilizada como referência para as redes e sua nomenclatura e também foi implementada e empregada nas redes internas (intranets) e na internet. Esse modelo é denominado pilha de protocolos TCP/IP que se trata de um conjunto de protocolos de comunicação entre computadores em rede. Essa arquitetura é composta por 4 camadas, equivalentes a fusão das camadas 5, 6, e 7 do modelo OSI para formar a camada de Aplicação do TCP/IP. As camadas 3 e 4 do modelo OSI são semelhantes às camadas 2 e 3 do TCP/IP e as camadas 1 e 2 do modelo OSI foram mescladas no TCP/IP para formar a camada de acesso à rede.

O TCP/IP é um dos primeiros protocolos que estruturaram a internet e foi desenvolvido pelo Departamento de Defesa dos EUA em 1969 para aprimorar os sistemas de redes internas, cuja arquitetura é feita de diversas camadas de software que interagem 
exclusivamente com as camadas acima e mais próximas do usuário e abaixo onde são usadas para os protocolos simples de solicitação de resposta. Para utilizar a internet, as redes locais distribuem servidores de acesso e os dispositivos são conectados desde que estejam configurados para utilizar o TCP/IP.

Quadro 4 - As camadas no modelo TCP/IP

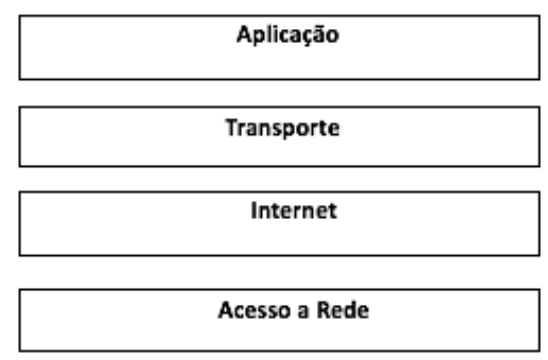

Fonte: Adaptado de Gargaz (2011, p. 29).

Nesse universo, o Marco Civil da internet procura normatizar esse sistema técnico, cuja premissa é a universalização da oferta de infraestrutura e que ainda está nas mãos das grandes operadoras, herança da privatização do setor de telecomunicação. Sancionada em abril de 2014, a Lei n. 12.965 garantiu direitos, regulamentação e a participação da sociedade civil no debate sobre o princípio da neutralidade da rede. Esse princípio garante que os conteúdos da internet sejam acessados por todas as pessoas em igualdade de condições, que as empresas fornecedoras do serviço não imponham restrições pelo preço por pacotes (como acontece hoje com a televisão a cabo) e que não detenham, ao mesmo tempo, a rede serviço e a rede suporte (como a Facebook e a Google, com suas estratégias de capilarizar seus serviços de conexão por drones, balões ou fibras óticas).

Para que haja neutralidade da rede, os agentes que controlam cabos, fibras óticas e outras estruturas físicas devem ser neutros em relação ao fluxo da rede serviço. Contudo, o aplicativo WhatsApp, propriedade da corporação Facebook, aplica um procedimento chamado zero rating, em que não há desconto na franquia de dados para conexão do aplicativo com acesso irrestrito e gratuito em parceria com empresas e operadoras de telecomunicações, aumentando sua influência e capacidade de vigilância sobre esse aplicativo, que é largamente usado pela maioria dos usuários de smartphone no Brasil. Operadoras como Tim, Vivo, Claro e Oi oferecem WhatsApp sem desconto na franquia, 
inclusive nos planos de $\mathrm{R} \$ 10,00$ por mês, e ele passa a ser requisito fundamental no serviço de telefonia móvel.

Desse modo, toda vez que uma corporação ou operadora interferir no fluxo de informação da rede impedindo o acesso a uma aplicação ou um serviço da internet por não estar num determinado plano ou bloquear o fluxo de informações, deixa-se de ser neutro em relação a esse fluxo. Ao fazer planos de diferentes velocidades e vender serviços específicos quebrando o acesso universal à internet, as operadoras a transformam numa grande rede de TV a cabo.

Há ainda diferenças importantes na normatização das chamadas internet fixa e internet móvel: na fixa, pela web, de onde se acessam os sites, há mais possibilidade de criação, e muitos sites são criados sem autorização. Já a internet móvel é mediada pela operadora de telecomunicação, visto que, por meio do smartphone, os aplicativos são filtrados e controlados pelas operadoras que se relacionam com o servidor que dá acesso à plataforma, pois, sem lojas que deem acesso a aplicativos como a AppleStore ou a GooglePlay, ${ }^{24}$ não se podem acessar aplicativos. Esse é, portanto, um âmbito muito controlado da rede, principalmente pelas corporações Facebook e Google, hegemônicas no mercado de redes, que tende ao monopólio, como mostram a compra do WhatsApp pela Facebook e a do Youtube pela Google. Assim, o ambiente da web aberta e pública pode ser apropriado corporativamente, enrijecendo-se e regulando a liberdade de criação e navegação (SILVEIRA, S., 2017a).

Conformada por uma arquitetura distribuída, a internet é um conjunto de redes articuladas por protocolos e procedimentos, e o smartphone processa as informações que fluem por elas. Por meio desse objeto técnico, as operadoras podem ter um controle absoluto, pela rede serviço e pela rede suporte, e isso é fundamental para a capilarização da informação pelo smartphone no território.

O maior poder das redes é produzir redes, e a prioridade de corporações como a Facebook e a Google é expandir e consolidar redes, tanto quanto produzir conteúdos. $\mathrm{O}$ Quadro 5 ilustra a velocidade de conexão que mostra a fluidez da informação e implica o

\footnotetext{
${ }^{24}$ Apple Store e Google Play são serviços de distribuição digital de aplicativos, jogos, filmes, programas de televisão, músicas e livros, desenvolvidos e operados pela Apple e pelo Google. Eles conformam uma loja oficial de aplicativos para os sistemas operacionais iOS e Android. Esse conteúdo é baixado diretamente no smartphone, onde o aplicativo é instalado. Os conteúdos podem ser gratuitos ou pagos e são acessados mediante a concordância do usuário em conceder seus dados.
} 
poder de produzir e fornecer, segundo um valor, o acesso mais rápido. Ressaltamos que essa velocidade de conexão é teórica, pois geralmente as operadoras não disponibilizam essa capacidade aos usuários.

Quadro 5 - Tempo necessário para download de conteúdo on-line em diferentes velocidades de conexão

\begin{tabular}{lccccc}
\hline \multirow{2}{*}{ Velocidade de conexão } & $\begin{array}{c}\text { 56 kbps } \\
\text { (kilobytes/s) }\end{array}$ & $\mathbf{2 5 6}$ kbps & $\begin{array}{c}\text { 2 Mbps } \\
\text { (megabytes/s })\end{array}$ & 40 Mbps & 100 Mbps \\
\cline { 2 - 6 } & \multicolumn{4}{c}{ Tempo de download (hh:mm:ss) } \\
\hline $\begin{array}{l}\text { Página web }(160 \mathrm{~KB}) \\
\left(1 \text { kilobyte }=10^{3} \text { bytes }\right)\end{array}$ & $00: 00: 23$ & $00: 00: 05$ & $00: 00: 64$ & $00: 00: 03$ & $00: 00: 01$ \\
\hline $\begin{array}{l}\text { Músicas }(5 \mathrm{MB}) \\
\left(1 \text { megabyte }=10^{6} \text { bytes }\right)\end{array}$ & $00: 12: 00$ & $00: 03: 00$ & $00: 00: 20$ & $00: 00: 01$ & $00: 00: 04$ \\
\hline Vídeo $(20 \mathrm{MB})$ & $00: 48: 00$ & $00: 10: 00$ & $00: 01: 00$ & $00: 00: 04$ & $00: 00: 02$ \\
\hline CD (700 MB) & $28: 00: 00$ & $06: 00: 00$ & $00: 47: 00$ & $00: 02: 00$ & $00: 00: 56$ \\
\hline $\begin{array}{l}\text { DVD }(4 \mathrm{~GB}) \\
\left(1 \text { gigabyte }=10^{9} \text { bytes }\right)\end{array}$ & 1 semana & 1,5 dia & $04: 30: 00$ & $00: 13: 00$ & $00: 05: 00$ \\
\hline
\end{tabular}

Fonte: Broadband Commission for Sustainable Development (2017).

Elaboração: Mait Bertollo.

O Quadro 6 mostra as unidades múltiplas do byte e expõe a magnitude da densidade dos dados trocados.

Quadro 6 - Unidades de medida em bytes

\begin{tabular}{lcc}
\hline \multicolumn{3}{c}{ Múltiplos do byte } \\
\hline Unidade & Símbolo & Valor \\
\hline byte & $\mathrm{B}$ & $10^{0}$ \\
\hline kilobyte & $\mathrm{Kb}$ & $10^{3}$ \\
\hline megabyte & $\mathrm{Mb}$ & $10^{6}$ \\
\hline gigabyte & $\mathrm{GB}$ & $10^{9}$ \\
\hline terabyte & $\mathrm{TB}$ & $10^{12}$ \\
\hline petabyte & $\mathrm{PB}$ & $10^{15}$ \\
\hline exabyte & $\mathrm{EB}$ & $10^{18}$ \\
\hline zettabyte & $\mathrm{ZB}$ & $10^{21}$ \\
\hline yottabyte & $\mathrm{YB}$ & $10^{24}$ \\
\hline
\end{tabular}

Fonte: Adaptado de Wikipédia (2016).

Essas possibilidades são concretizadas por intermédio de um sistema que permitiu a um dispositivo ler e interpretar todos os sinais recebidos. O smartphone passou por vários estágios de desenvolvimento para se constituir num telefone e, ao mesmo tempo, num computador. 
O primeiro celular foi criado pela empresa Motorola em 1974, quando também foi fixada a primeira estação rádio base em Nova York, EUA. Após dez anos, o primeiro celular com um teclado numérico de base, um display e uma bateria de uma hora de duração para conversação, chamado DynaTAC, foi comercializado pela Motorola. No início da década de 1990, começa o desenvolvimento das primeiras mensagens de texto e dos processadores de sinais digitais. Em 1993, as empresas IBM e Bell South lançaram o comunicador pessoal Simon, que enviava e recebia chamadas de voz e tinha uma agenda de contatos, calculadora, pager e fax, com a primeira tela touchscreen. Em 1996, a Motorola comercializou o StarTAC, que enviava e recebia mensagens de texto SMS, funcionava com bateria de lítio e pesava apenas $100 \mathrm{~g}$.

Em 1998, o celular passou a ser mais acessível, com o modelo Nokia 6160, que pesava 160 g e tinha display monocromático e uma bateria que provia três horas e vinte minutos de conversação. No mesmo período, comercializava-se o celular BlackBerry, com um tipo de pager e teclado QWERTY ${ }^{25}$ para transmitir mensagens SMS, e-mails e páginas, além de um display.

A partir dos anos 2000, surgiram as câmeras integradas, simultaneamente com as redes $2 \mathrm{G}, 3 \mathrm{G}$ e GPRS, e, aos poucos, começou a estagnação dos investimentos em rede celular analógica em favor da rede digital. Esse objeto técnico, ainda com poucas funcionalidades, foi convertido no smartphone, com várias funcionalidades e, a partir desse momento, capaz de conectar-se à internet, ler e editar arquivos de texto. Já no ano 2000, a Ericsson introduziu a tecnologia bluetooth ${ }^{26}$ para a conexão sem fio de smartphones com computadores, aumentando a conectividade entre os objetos. Em 2007, com sua entrada no setor de telefonia celular, a Apple substituiu o teclado convencional pela touchscreen $^{27}$ e criou um sistema operacional com vários recursos de um computador com aplicativos, configurando o smartphone como ele é hoje.

\footnotetext{
${ }^{25}$ QWERTY é o modelo aplicado à maioria dos computadores e das máquinas de escrever. O nome vem das primeiras seis letras da primeira linha do teclado.

${ }^{26}$ Bluetooth é uma rede sem fio que conecta e troca informações entre dispositivos como smartphones, notebooks, computadores, impressoras, câmeras digitais etc. por meio de uma frequência de rádio de curto alcance.

${ }^{27}$ Touchscreen é uma tecnologia que usa sensores que detectam o toque dos dedos e o transformam em comandos no sistema operacional.
} 


\subsection{O objeto técnico smartphone}

Para conhecer o funcionamento do smartphone sob a ótica espacial, partimos do princípio de que os objetos técnicos tendem a constituir conjuntos complexos de acordo com a interconexão entre os diferentes indivíduos que os utilizam (SIMONDON, 2007).

Os dispositivos automatizados são cada vez mais sensíveis ao funcionamento de outras máquinas e dispositivos, como é o caso da conexão do smartphone à internet, que lhe permite executar certas tarefas. Esse fato resulta de um sistema de autorregulação que gere as variáveis produzidas por outros objetos técnicos individualizados.

Para Simondon (2007), a linha divisória no funcionamento dos dispositivos e máquinas conectados e mais autônomos é a integração dos conjuntos técnicos com a presença simultânea do ser humano nesse movimento. A organização da operação coordenada dos objetos técnicos implica forçosamente uma intenção humana no próprio objeto.

Nesse contexto, os objetos técnicos se desenvolvem compondo uma família numa linhagem em função do modo como se articulam em cadeias de humanos ou não humanos, fazendo desaparecer a dicotomia entre homens e máquinas. Assim, os objetos técnicos não são pensados a partir de sua exterioridade em relação ao ser humano, como no conhecido "risco do domínio das máquinas sobre a humanidade", pois o potencial perigo está na hibridez com que seres humanos e objetos técnicos criam um meio de controle e dominação.

No começo do século XX, o papel dos seres humanos na sua relação com objetos e máquinas é relativamente desconsiderado no tocante às ciências mecânica, à resistência dos materiais, à termodinâmica etc. (MOLES, 1969). Mas, quando se trata do sistema de objetos comunicacionais, os seres humanos têm uma interação como de um transmissor para um receptor.

As mensagens são transmitidas e recebidas por uma cadeia de dispositivos, como é o caso do canal de comunicação que transmite mensagens e informações através da internet para o smartphones por meio de ERB (Figura 2). 
Figura 2 - O percurso da internet móvel no Brasil

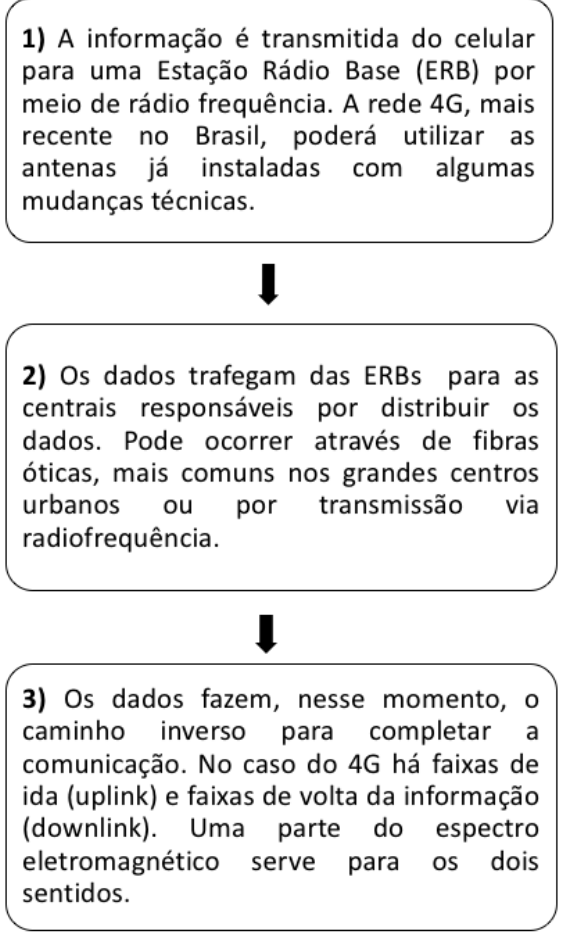

1) A informação é transmitida do celular meio de radio frequência. A rede 4G, mais recente no Brasil, poderá utilizar as antenas já instaladas com algumas mudanças técnicas.

2) Os dados trafegam das ERBs para as centrais responsáveis por distribuir os dados. Pode ocorrer atraves de fibras urbanos ou por transmissão via radiofrequência.

\section{I}

3) Os dados fazem, nesse momento, o
caminho inverso para completar a
comunicação. No caso do 46 há faixas de
ida (uplink) e faixas de volta da informação
(downlink). Uma parte do espectro
eletromagnético serve para os dois
sentidos.

Fonte: Kurose (2010).

Adaptação: Mait Bertollo, 2018.

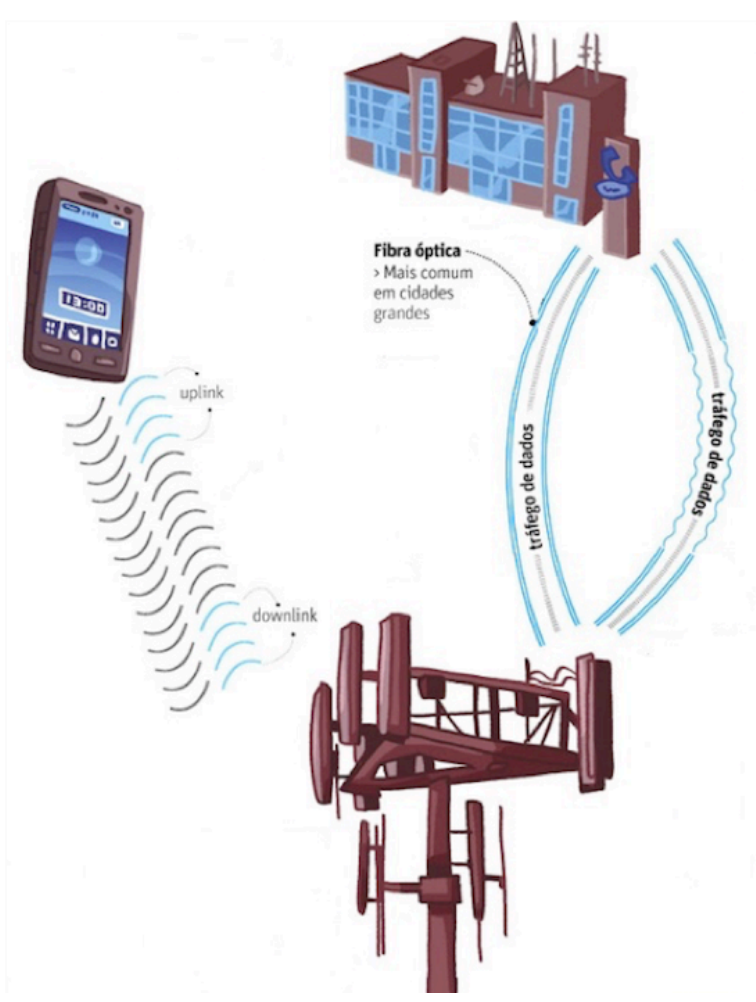

A mensagem transmitida por esses objetos técnicos é uma sequência de elementos de um repertório que tem materialidade (MOLES, 1969). O uso dos canais artificiais de comunicação transporta alguma coisa do transmissor ao receptor, e uma mensagem tem uma "taxa da informação" mensurável e transfere a complexidade de um ponto a outro do mundo (MOLES, 1969).

Tanto em sistemas quanto isoladamente, os objetos estão condicionados às circunstâncias de seus prolongamentos sociais, não estabelecendo nada por si sós, evidentemente, mas concorrendo para criar novas possibilidades no contexto da comunicação (DOSSE, 2003).

Para recebimento ou envio de informações pelo smartphone, consideram-se dois eixos propostos por Dosse (2003): um temporal, relativo à interpretação e à atribuição de sentido, e outro espacial, que é o caminho das informações de um ponto a outro. Esse encadeamento conforma as tecnociências, indissociáveis e híbridas, em que se combinam o humano e o não humano. 
As tecnologias da comunicação envolvem não só habilidades motoras e atividades práticas, mas também o potencial de comunicar e entender a realidade (MCLUHAN, 2002). As tecnologias operam diretamente nos mecanismos de percepção a partir de seu uso ou indiretamente, pelos efeitos de sua existência no nosso meio:

[...] a projeção ou extensão de nosso corpo e de nossos sentidos numa "nova invenção" obriga nosso corpo e nossos sentidos a se deslocarem para novas posições a fim de manter o equilíbrio. Toda nova invenção efetua um novo "fechamento" em nossos órgãos e sentidos, privados e públicos. A visão e a audição assumem novas posturas - como todas as demais faculdades (MCLUHAN, 2002, p. 282).

Para Flusser (1985, p. 192), os aparelhos audiovisuais interagem na realização do imaginário humano com a "produção de imagens e sons tecnicamente mediados pelo poder de abstração e cálculo dos aparelhos".

O smartphone passou a ter um papel agregador fundamental, ao proporcionar ao indivíduo a conexão e a mobilidade, constituindo uma "sociedade em midiatização [...] [em que a] subjetividade dos agrupamentos humanos passa a ser estabelecida a partir do texto, do intercâmbio de imagens e sons por meio da interação com os dispositivos eletrônicos miniaturizados e móveis" (GOMES, 2016, p. 14).

Esse dispositivo realiza múltiplas tarefas, como um computador de mão, e sua denominação "telefone inteligente" é associada à capacidade de seu sistema operacional, com certos aplicativos, de reproduzir o funcionamento de vários aparatos, como um aparelho que emula outros aparelhos: câmera fotográfica e filmadora, gravador e reprodutor de som e vídeos, conexão à internet etc., apropriando-se de funções banais do cotidiano dos usuários (SILVEIRA, S., 2017a).

Ao mesmo tempo em que permite uma operação facilitada e intuitiva de seus aplicativos e do sistema on-line, do ponto de vista técnico dos componentes de hardware, esse objeto técnico tem uma complexidade pouco conhecida, cuja compreensão requer formação específica. Os aplicativos instalados num smartphone cumprem funções que se adéquam às finalidades dos usuários e, desse ponto de vista:

[...] os smartphones são dispositivos multissensoriais, que integram nossas faculdades perceptivas através de sua capacidade audiovisual, e também de todo um gestual tátil necessário para operá-lo. Ao mesmo tempo, é uma máquina de cálculo, uma vez que toda informação audiovisual que chega aos nossos sentidos é uma concretização realizada pelos algoritmos que operam 
as informações abstratas que atravessam os circuitos do aparelho. Assim, ao pensarmos os smartphones como dispositivos de escuta, estamos focando no seu potencial de reprodução, geração, edição, transmissão e recepção de arquivos de áudio; operações que decorrem do uso de programas específicos que emulam tais funções nos smartphones (SILVEIRA, S., 2017a, p. 89).

Para Latour (2001, p. 112), os objetos técnicos são obscuros como uma caixa preta: quando se materializa num objeto, o trabalho científico e técnico se torna invisível. Quando uma máquina funciona bem, a única demanda é alimentá-la e produzi-la, desconsiderando sua complexidade interna; então, paradoxalmente, "quanto mais a ciência e a tecnologia obtêm sucesso, mas opacas e obscuras se tornam" (LATOUR, 2001, p. 112).

Quando tomada na escala global, a banalização do smartphone representa a ação de “objetos indutores de inteligência coletiva" (LÉVY, 1996, p. 96), visto que o compartilhamento de memórias se faz de forma interativa, diferentemente, por exemplo, da televisão, cujos telespectadores apenas recebem a informação.

Os objetos sempre apareceram sucessivamente na história da humanidade, e cada qual corresponde a uma forma específica de cada dinâmica e formação socioespacial, considerando que "toda mudança social consequente implica uma invenção de objeto" (LÉVY, 1996, p. $101)$.

Segundo Moles (1973), a multiplicação de objetos relaciona-se a seu desenvolvimento em série, com mais ou menos normalizações, juntamente com o consumo ostensivo, articulando o status social com a posse de objetos. A vida cotidiana é tomada por objetos que são um vetor de comunicação e concretizam as ações dos seres humanos dentro da sociedade.

O objeto não é natural; ele é diferente do que se chama de coisa, pois "em nossa civilização, objeto não é natural, não se fala numa pedra, numa rã ou numa árvore como um objeto, mas antes como uma coisa. A pedra só se tornará objeto quando for promovida a peso de papéis" (MOLES, 1973, p. 202).

Assim, os indivíduos estão ligados ao smartphone como objeto técnico particular e privativo por meio de seu desejo, de seu prazer e mesmo da falta que podem sentir dele (MOLES, 1973), estimulado, pelo período, pela mass media e pela presença crescente das tecnologias da informação que influenciam as práticas sociais, especialmente as mais banais. 
Os grandes sistemas técnicos da comunicação são compostos por conexões entre infraestruturas em rede, com um comando centralizado que visa seu funcionamento eficaz, e são entendidos como cadeias de associações de humanos $(\mathrm{H})$ e não humanos $(\mathrm{NH})$ (LATOUR, 2001). Esse sistema pode ser composto por inúmeros elementos, cuja organização pode ser, por exemplo, com a de uma cadeia H-NH-H-NH-NH-NH-H-H-H-H-NH.

Nessa perspectiva, o elemento humano pode ser sintetizado nas relações sociais e o não humano, em mecanismos, dispositivos e estruturas como máquinas, que estão sempre adaptados e integrados em cadeias mais extensas:

Ao invés de perguntar "isto é social?", "isto é técnico?", ou "estas técnicas são influenciadas pela sociedade?" ou "esta relação social é influenciada pelas técnicas?" nós apenas perguntamos: um não-humano substitui um humano? A competência desse ator foi modificada? Este ator - humano ou não humano - foi substituído por outro? Esta cadeia de associação foi ampliada ou modificada? (LATOUR, 1991, p. 110).

Logo, quando o poder das redes é criar redes, não há prioridade entre exercer poder sobre um elemento humano ou um elemento não humano, pois o poder está em controlar a cadeia desses dois elementos.

O termo técnica também pode ser aplicado a um subprograma ou a uma série de subprogramas embutidos uns nos outros, e as intenções que agem sobre esses objetos são reconhecíveis e são propriedades de "pessoas jurídicas que estão aptas a absorver a proliferação de mediadores, a regular sua expressão, a redistribuir habilidades, abrir as caixas, obscurecer-se e fechar-se" (LATOUR, 2001, p. 222).

Para existir, os objetos devem estar incorporados à vida coletiva, pois as ciências e a tecnologia tornam sociáveis os não humanos para que estabeleçam relações humanas. A extensão das redes de telecomunicações que mobiliza intensamente o smartphone está sob o controle de ondas eletromagnéticas, usuários, fibras óticas, antenas, sinais de radiofrequência e satélites, e, assim, esse sistema adquire "um caráter formal e universal de leis científicas" (LATOUR, 2001, p. 236). Nas cidades, a população urbana que se conecta a várias redes, sobretudo à internet, é a grande massa que está sob o controle de humanos, e, com suas propriedades organizacionais, os não humanos fazem o monitoramento das pessoas em larga escala de redes de agentes hegemônicos. 


\subsection{Técnica e território: capilarização da informação pelas redes e realização da simultaneidade através de cabos de fibra ótica (backbones)}

As infraestruturas das redes suporte e das redes serviço que proporcionam a conexão dos indivíduos pelo smartphone à internet são compostas de camadas que se intercomunicam e funcionam de forma associada. O desempenho de seus elementos é interescalar, desde as grandes estruturas como os cabos submarinos até os algoritmos e aplicativos executados pelo smartphone.

Inicialmente, a chamada rede física, que compõe as primeiras transferências da rede, é a base material imprescindível para que todo o sistema funcione e se possam fazer interconexões. A rede composta por backbones, ou cabos submarinos, é formada por condutores feitos de fibra ótica, de longa distância e alta capacidade de transmissão de dados, que interconecta pontos de forma interescalar.

O backbone é a estrutura fundamental de transporte de dados, onde o fluxo de informações é mobilizado e interliga vários pontos. Essa estrutura é um conjunto de pontos de internet que transportam dados entre diversos lugares: por exemplo, para acessar um site do México de um ponto do Brasil, a conexão passa por um backbone nacional até chegar aos pontos de interconexão que conectam o Brasil e o México. Em território mexicano, a conexão passa por outro backbone para encontrar o datacenter que hospeda os servidores do site pretendido.

Os cabos de fibra ótica conduzem pulsos de luz, e cada um desses pulsos representa um bit, sendo possível comportar taxas de transmissão de centenas de gigabits por segundo. $\mathrm{O}$ material que os compõe é imune à interferência eletromagnética e têm um funcionamento estável.

A possibilidade de enviar mensagens, dados e informações e fazer ligações por videochamada para uma pessoa que está em outro continente, efetivando a simultaneidade, se deve fundamentalmente à operação dos cabos de fibra ótica submarinos, que têm o diâmetro da palma de uma mão (Figura 3). Na foto à esquerda, um cabo submarino para águas profundas; à direita, um cabo submarino com proteção reforçada, para águas mais rasas. 
Figura 3 - Diâmetro dos cabos de fibra ótica submarinos
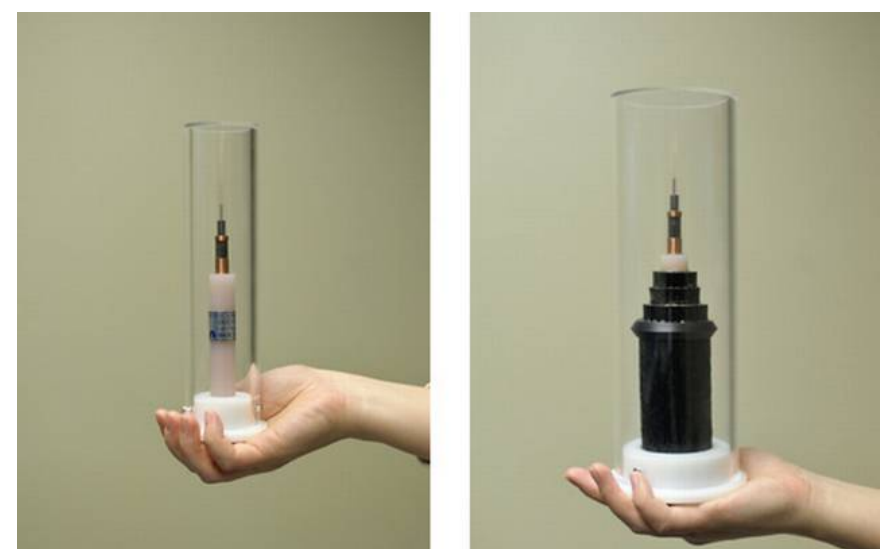

Fonte: NEC (2018).

Para garantir a velocidade de transmissão, os sinais são transformados em luz, com o auxílio de conversores integrados aos transmissores. Sua proteção externa evita desgastes e é composta por plásticos; abaixo dela, uma cobertura protege a fibra de vidro e evita que a luz natural atinja as fibras internas (Figuras 4 e 5).

Figura 4 - Estrutura de um cabo de fibra ótica

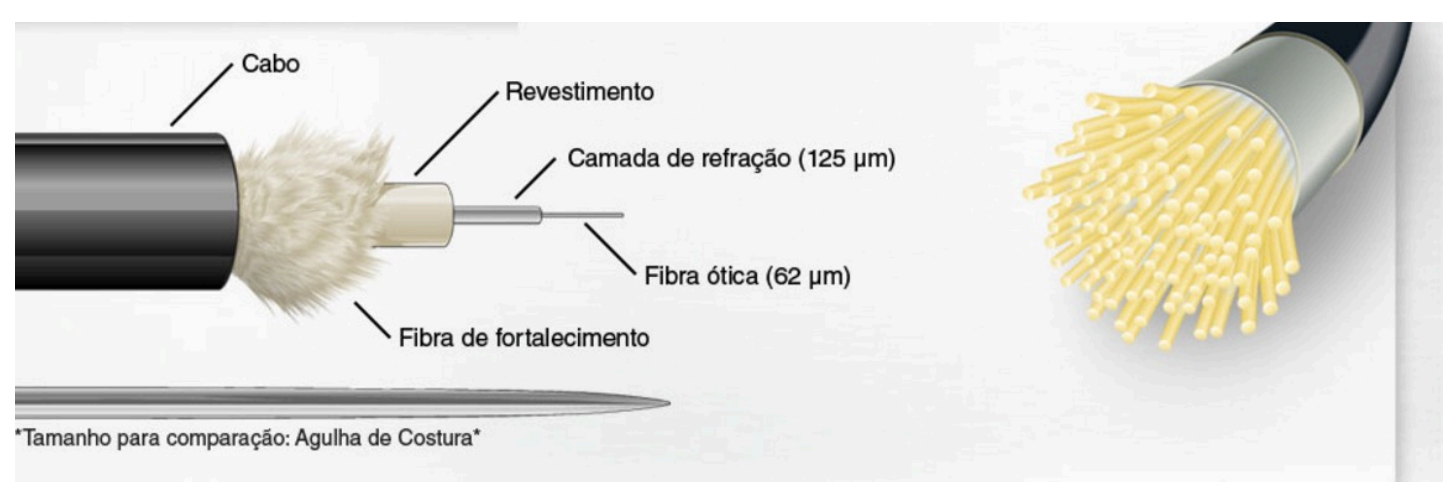

Fonte: Museu das Comunicações (2018). 
Figura 5 - Componentes do sistema de conversão de dados em luz e vice-versa

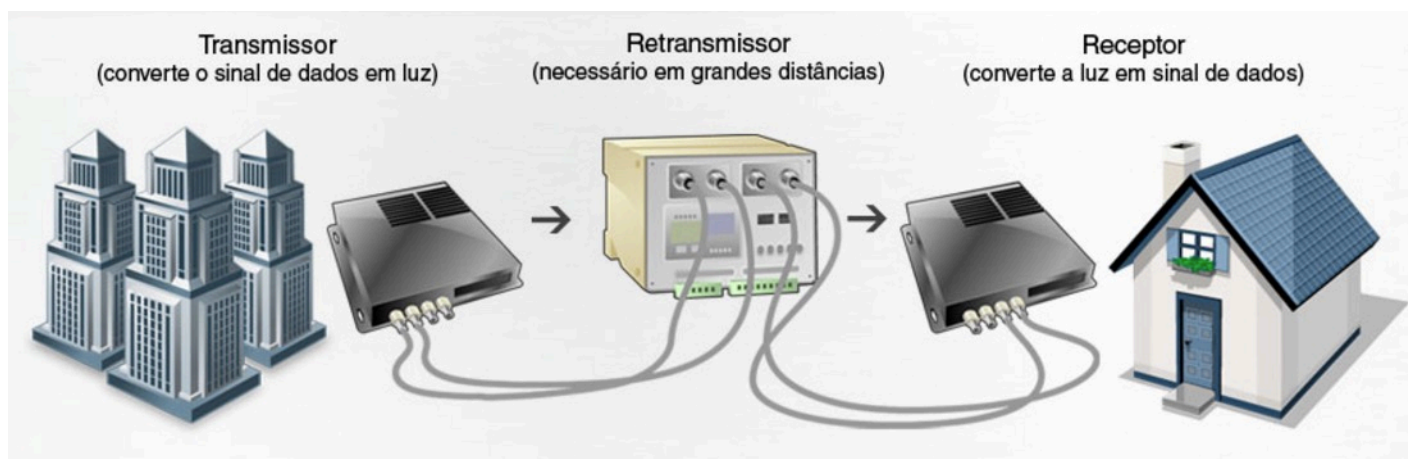

Fonte: Museu das Comunicações (2018).

A estrutura de backbones perfaz redes nacionais e internacionais, e as redes brasileiras presentes no território começaram a ser construídas em 1997, por meio de uma matriz de pares de ligações, com conexões entre municípios baseadas na Rede Nacional de Ensino e Pesquisa (RNP), rede pública que interconecta universidades e outras instituições de ensino e pesquisa.

As diferentes cidades se inter-relacionam de acordo com a disponibilidade dessa infraestrutura, distinguindo os nós mais importantes dos periféricos, com sub-redes e grupos de nós. O Mapa 3 ilustra a distribuição dos nós dessa rede no território brasileiro, conectando os principais pontos das capitais de todos os estados com diferentes velocidades de conexão.

Essa estrutura agrega as redes individuais de cada companhia de telecomunicações que atua no setor de fibras óticas de longa distância no Brasil. O tráfego de informações circula em 565 pontos (REDE NACIONAL DE ENSINO E PESQUISA, 2016), e cada qual corresponde ao local físico onde estão os roteadores e demais equipamentos que dão acesso à rede, interligando centenas de municípios. Há estados com intensa capilaridade e outros que só se conectam pelo nó da capital.

Os principais backbones nacionais são das empresas Embratel, RNP, Oi/Brasil Telecom, KDD Nethal, Comsat Brasil, Impsat Comunicações, AT\&T, NTT, Diveo do Brasil, CTBC, Mundivox do Brasil, Telefonica, Intelig e Geodex GVT. Os estaduais são da Academic Network at São Paulo (ANSP) (SP), Rede Norte-riograndense de Informática (RN), Rede Pernambuco de Informática (PE), Rede Rio (RJ), Rede Tchê (RS) e Remav (Redes Metropolitanas de Alta Velocidade) (MINISTÉRIO DAS CIÊNCIAS E TECNOLOGIA INOVAÇÕES E COMUNICAÇÕES, 2018). 
Mapa 3 - Rede de backbone com capacidade agregada de $347 \mathrm{~Gb} / \mathrm{s}$ e capacidade internacional de 116 $\mathrm{Gb} / \mathrm{s}$, Brasil, 2016

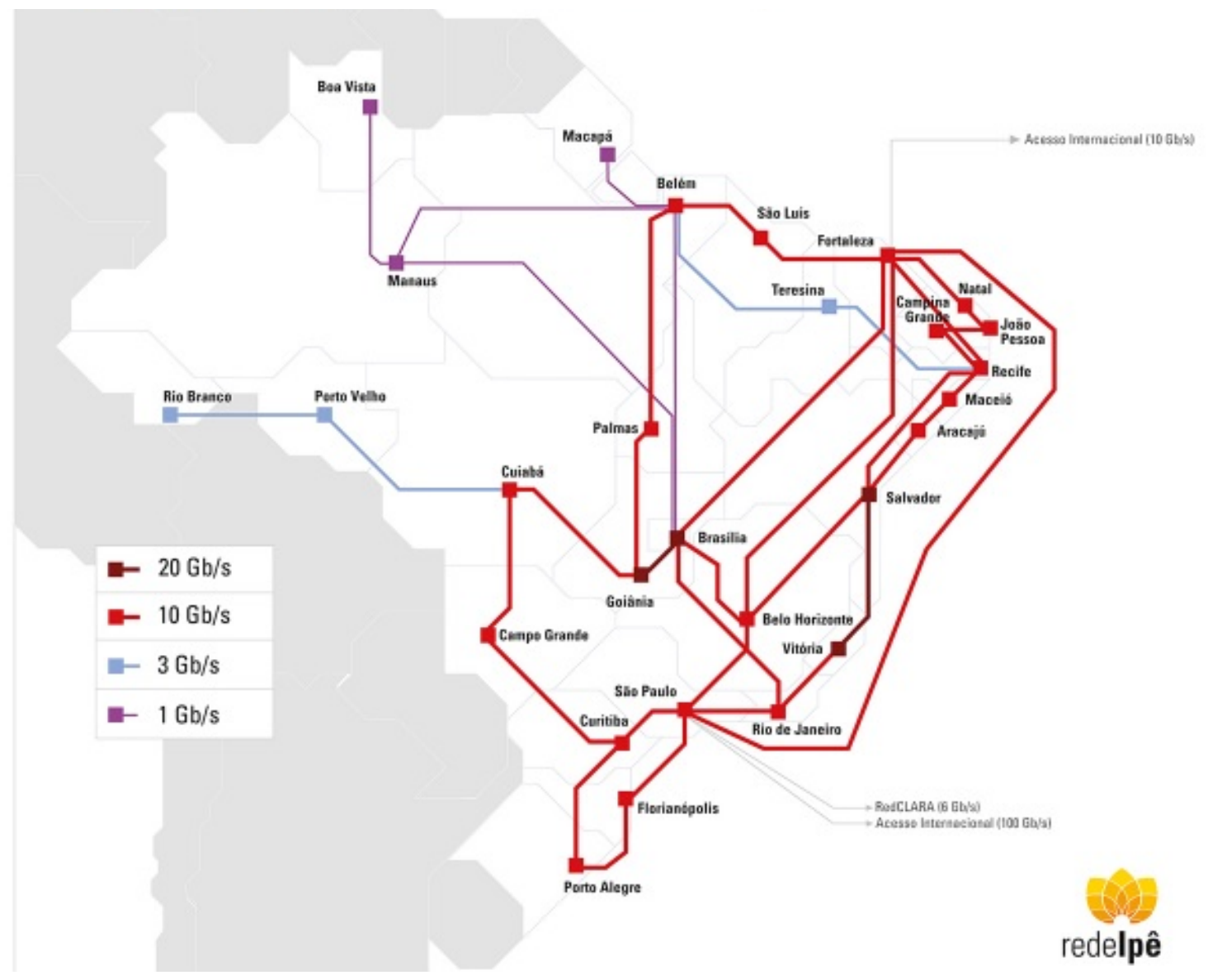

Fonte: Rede Nacional de Ensino e Pesquisa (2016).

O suporte desigual no território quanto ao fornecimento do serviço de conexão à internet segue a densidade populacional, a acumulação de riqueza e a densidade de redes técnicas das regiões metropolitanas. Elas têm melhor cobertura, maior número de linhas e de pontos de assistência, melhor qualidade e mais velocidade de conexão, atendendo ao objetivo de rentabilidade das corporações de telecomunicações, que investem em áreas com maior potencial de retorno do capital aplicado.

Frequentemente, a implantação das redes obedece a critérios binários como deficiência x presença de infraestrutura ou conexão x desconexão das redes. Contudo, mesmo entre os pontos conectados, sua posição relativa aos demais pontos define suas possibilidades, pois algumas posições são mais influentes que outras, e cada ponto interage de maneira distinta e mediada com o conjunto da rede (SHEPARD, 2002).

Segundo Sheppard (2002), a "posicionalidade" aplicada aos backbones condiciona a forma pela qual a rede é aproveitada e usufruída. Os centros urbanos secundários e com 
menos acessibilidade estão num nível inferior nessa rede, pois o tráfego e o fluxo de dados atravessam mais etapas para alcançá-las, aumentando sua latência, isto é, implicando atraso no recebimento dos dados.

No âmbito internacional, a rede promove a troca de informações entre países e continentes por cabos de fibra ótica submersos. Ela dá prioridade à centralização e à transferência de informações e, numa escala local, as empresas se responsabilizam por manter as rotas em funcionamento nos pontos que atendem.

Um elemento importante desse funcionamento é o backhaul, que liga o backbone e a chamada última milha, que é o cabo entre o $\operatorname{roteador}^{28}$ e a prestadora de serviços de internet, portanto, liga o núcleo da rede, ou backbone, e as sub-redes periféricas. A princípio, o fluxo entra no domínio do caminho principal, que é o backbone. Na rede que atende a conexão do smartphone à internet, uma única ERB constitui a sub-rede local e, para conectá-la a outros pontos do planeta, faz-se uma ligação backhaul ao backbone da companhia telefônica. Assim, o backhaul é a parte do sistema que distribui o tráfego com mais capilaridade.

Dos sistemas técnicos que também distribuem e armazenam dados, a nuvem caracteriza uma rede global de servidores, cada qual com uma função única. A nuvem é composta de uma ampla rede de servidores remotos distribuídos pelo planeta que são conectados e funcionam como um sistema único. Esses servidores armazenam e gerenciam dados, executam aplicativos e oferecem serviços de comunicação como chamadas de vídeo, $e$ mails, armazenamento de arquivos etc. Os arquivos são acessados on-line, por meio de um smartphone funcionando como um HD (hard disk) externo. Existem a nuvem pública, cujos serviços são gratuitos, a nuvem privada, que fornece serviços numa rede interna particular, a nuvem híbrida, que compartilha serviços entre nuvens públicas e particulares, e a nuvem de comunidade, que compartilha recursos apenas entre organizações como instituições governamentais (MICROSOFT, 2018).

Quanto à capacidade de transmissão de dados, os cabos submarinos são responsáveis por $99 \%$ das comunicações entre continentes, isto é, a fibra ótica é o alicerce fundamental da internet, pois é o meio que tem a maior capacidade de transmissão de dados (SODRÉ JR.,

\footnotetext{
${ }^{28} \mathrm{O}$ roteador é um aparelho que interliga computadores e/ou smartphones, e o compartilhamento de arquivos na rede permite a conexão simultânea de todas as máquinas à internet. Ele reconhece um microcomputador que se conecta à rede e define um IP (internet protocol), que é um identificador único para cada dispositivo conectado. Sua tarefa é organizar os dados que trafegam pela rede.
} 
2018; STAROSIELSKI, 2014; MAIN, 2015). Essa estrutura pode transmitir até 3.840 gigabits por segundo (NEC, 2018), correspondentes a 102 DVDs por um segundo; como cada cabo pode conter centenas de fibras, sua capacidade pode chegar a 64 terabits por segundo.

Por outro lado, os satélites têm capacidade de transmitir um DVD por segundo (NEC, 2018) e são usados geralmente em cidades distantes dos grandes centros ou em áreas rurais. A comunicação vai do usuário ao satélite e deste ao servidor, e esse processo requer dois modem $^{29}$ e uma mini antena parabólica; o custo dos equipamentos e do serviço é bem mais altos do que o de outros modos de conexão.

A antena transmite os dados para o satélite, que recebe a requisição do usuário e retorna os dados pedidos. Sua configuração técnica pode tornar a conexão menos estável, pois qualquer objeto que passe na frente da antena, desde nuvens até chuva, pode interromper a ligação com o satélite.

A vantagem técnica da fibra ótica sobre os satélites é a variável distância, pois, por meio dessas vias no fundo dos oceanos, o percurso dos fluxos é menor do que no caso do satélite: a distância entre a costa leste dos EUA e o Japão é de aproximadamente 9 mil quilômetros por terra, diferentemente de um satélite geoestacionário, que está a 36 mil quilômetros, isto é, para que o sinal chegue de um país a outro, ele deve viajar de um ponto até o satélite e do satélite até o outro ponto, perfazendo 72 mil quilômetros.

A estrutura do backbone numa escala pequena funciona por meio de sinais de luz que passam por fibras óticas, que formam canais da espessura de um fio de cabelo e são organizados em feixes que transmitem uma grande quantidade de informações ininterruptamente, com mais capacidade do que, por exemplo, um cabo elétrico. Os milhares de quilômetros de cabos sob os oceanos ficam a até 8 mil metros de profundidade e, pelo mapeamento do relevo do fundo do mar, o percurso dos pode evitar montanhas, vales e recifes de corais.

Nos pontos mais rasos, os cabos são inseridos no solo com ferramentas especializadas por meio de navios. Abrem-se fendas no fundo dos oceanos para enterrá-los e ainda se aproveitam as correntes marítimas para ocultá-los, resguardando-os de âncoras, ataques de tubarões, redes de pesca etc. Para organizar os cabos e enrolá-los, no caso de uma unidade de

\footnotetext{
${ }^{29} \mathrm{O}$ modem é um dispositivo de entrada e saída usado para transmitir dados entre computadores e smartphones por meio de linha telefônica.
} 
3 mil quilômetros, são necessárias três semanas, e seu posicionamento também requer uma série de aparatos e tecnologias, posto que as correntes oceânicas afetam o percurso até o fundo.

Até o fim de 2017, havia 428 cabos submarinos distribuídos no planeta, perfazendo uma extensão de um milhão de quilômetros (TELEGEOGRAPHY, 2018). A Antártida é o único continente que não tem ligações com a rede de cabos de fibra óptica, que não suportam as temperaturas baixas e os choques resultantes do deslocamento de icebergs. Essa estrutura pode durar 25 anos e, dado seu alto custo de manutenção, é mais econômico instalar uma nova e abandonar a antiga no oceano.

O Brasil é ligado a outros países por oito cabos de fibra ótica, e mais sete estão em fase de implantação para operar a partir do fim de 2019. Outro cabo que começa a funcionar no fim de 2018 é o Júnior, da Google, que mede 400 quilômetros e ligará a Praia Grande, no litoral paulista, à praia da Macumba, no Rio de Janeiro, e ainda dois outros cabos, também de propriedade da Google. Um deles é o chamado Monet, que liga Santos (SP) a Fortaleza (CE) e a Boca Ratón, na Flórida, EUA. O segundo se chama Tannat e parte de Santos (SP) até Maldonado, Uruguai. Outros cabos cruzam o Oceano Atlântico até o continente europeu, como o Atlantis-2, implantado em 2000, que começa em Fortaleza (CE), passa pelo Senegal, na África, e pelas ilhas Canárias espanholas e termina em Carcavelos, Portugal.

Um cabo também essencial para a conexão do Brasil com outros continentes é o EllaLink, pertencente à Telebras e à espanhola IslaLink, que começará a funcionar no fim de 2019, conectando Santos (SP) e Fortaleza (CE), passando por Cabo Verde e pela Ilha da Madeira até Sines, em Portugal; seu custo é de US\$ 206 milhões, e sua extensão, 9.400 quilômetros.

Outra empresa que opera na conexão do Brasil com outros países é a South Atlantic Cable System (SACS), da Angola Cables, em funcionamento nas cidades de Fortaleza (CE) e Luanda, em Angola. O tempo de transmissão de dados entre suas duas pontas é de 63 milissegundos. Em 2024, haverá uma conexão de Recife (PE) à Cidade do Cabo, na África do Sul, pelo cabo chamado SABR, ligando Fortaleza (CE) a Kribi, em Camarões. O Mapa 3 mostra as empresas que fazem a ligação internacional de cabos de fibra ótica, oligopolizando vários percursos entre importante nós globais. No Mapa 4, vemos um panorama da distribuição das redes de backbone pelo globo. 
A partir do momento em que o smartphone se popularizou, cresceu a demanda de mais aplicações, maior velocidade e capacidade de conexão para compartilhar e receber dados de voz, imagem e vídeos em alta resolução, pressionando por um aumento da rede de cabos óticos terrestres e submarinos.

Mapa 4 - Cabos submarinos internacionais que ligam o Brasil a outros países e continentes, 2018

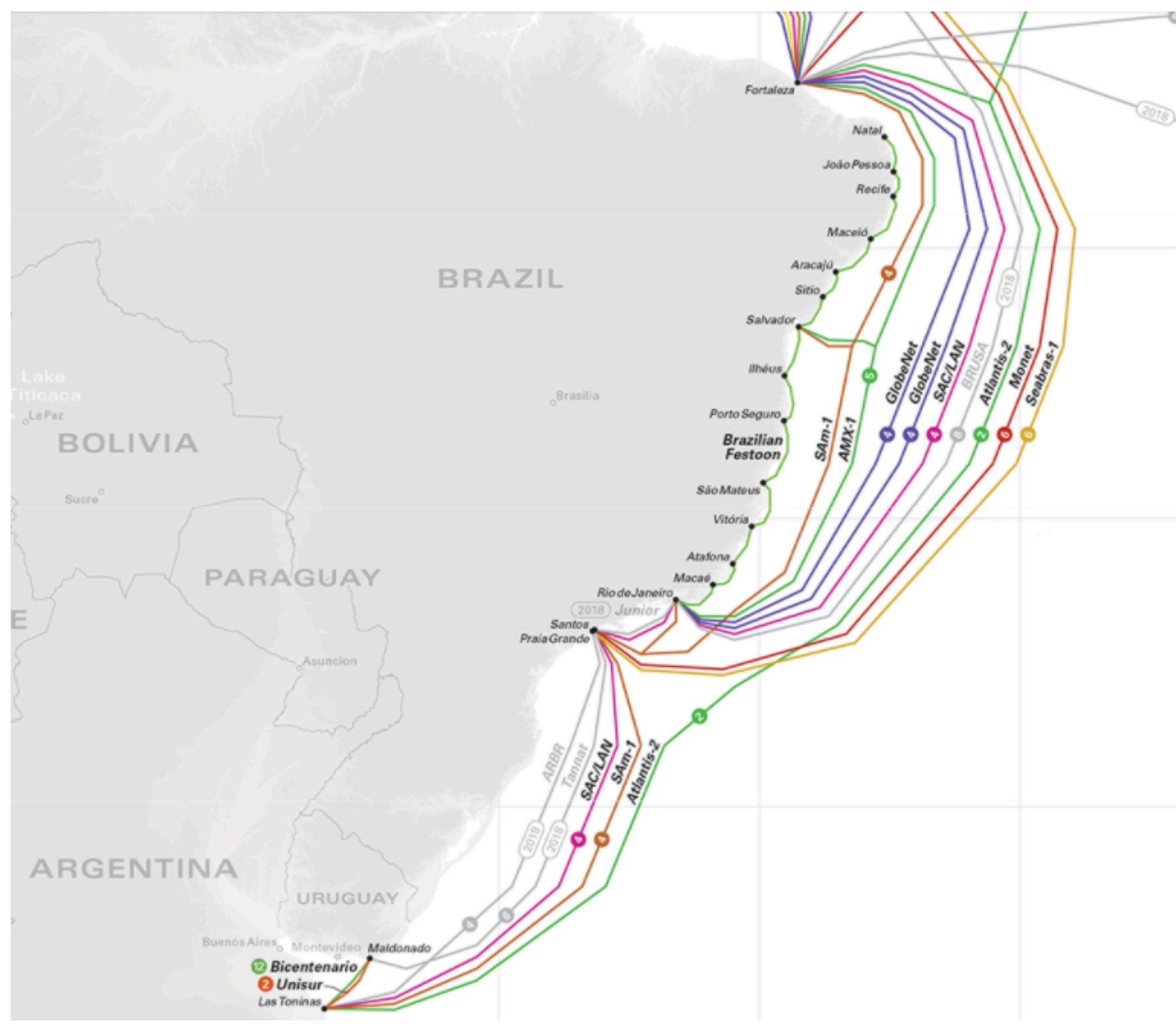

Fonte: Telegeography (2018). 
Mapa 5 - Cabos submarinos internacionais, 2018

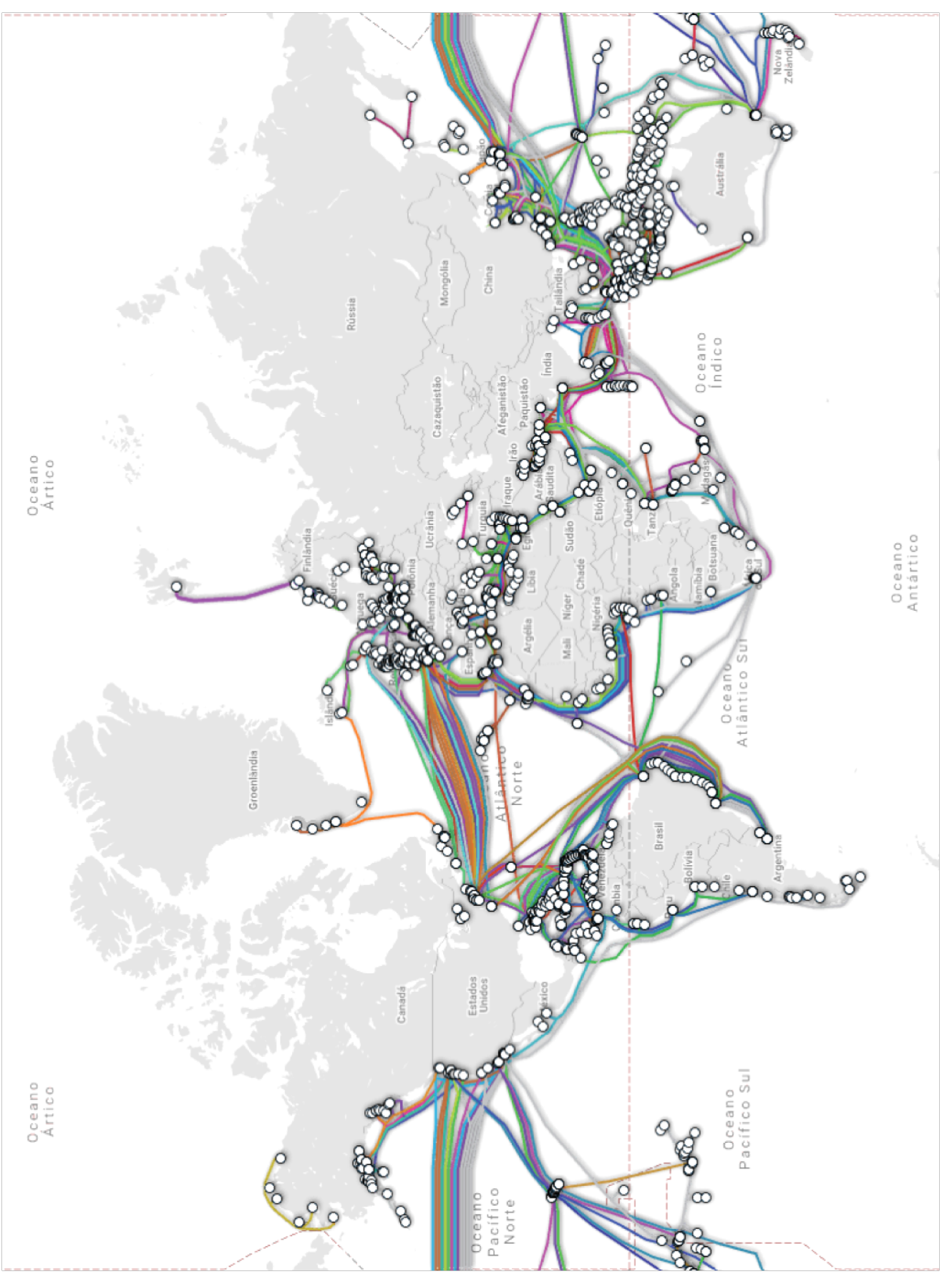

Fonte: Telegeography (2018).

No Mapa 4, vemos o percurso dos cabos SAC/LAN e Sam-1, que partem de Maldonado, Uruguai, conectam-se à cidade de Santos (SP), e o do Atlantis-2, que parte para Fortaleza (CE), onde se bifurca em direção ao norte do globo. Vemos ainda que o cabo Brazilian Festoon percorre o litoral e se conecta ao cabo AMX-1 em Salvador, igualmente rumo ao hemisfério norte. Muitos cabos também começam na cidade do Rio de Janeiro (RJ), como o GlobeNet, o SAC/LAN e o Seabras-1, interconectados em outros pontos ao norte. O 
Mapa 6 mostra os cabos transatlânticos brasileiros, as empresas detentoras, seu comprimento e capacidade, o que ilustra a complexidade dessa rede e sua distribuição.

Mapa 6 - Cabos submarinos transatlânticos, empresas detentoras, comprimento e capacidade de transmissão, 2018

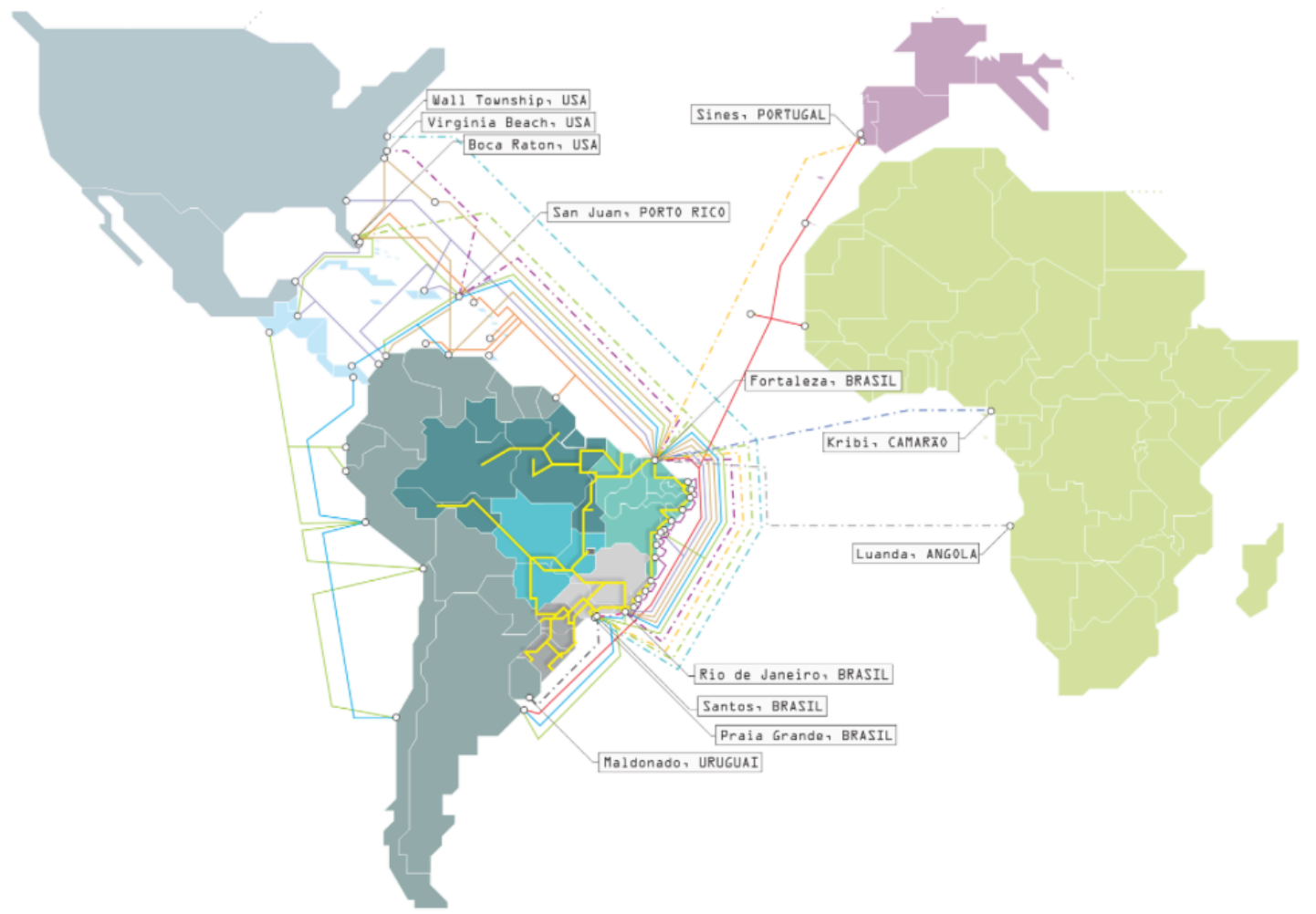

Legenda:

\begin{tabular}{|c|c|}
\hline & Cabos existentes antes de 2016 \\
\hline $\begin{array}{l}\text { Cameroon- } \\
\text { Brasil } \\
\text { Cabel System }\end{array}$ & $\begin{array}{l}\text { Data de operação: } 2017 \\
\text { Comprimento do cabo: } 5.900 \mathrm{~km} \\
\text { Capacidade de tráfego: } 32 \mathrm{~Tb} / \mathrm{s} \\
\text { Proprietárias: Camtel e China Unicom }\end{array}$ \\
\hline & $\begin{array}{l}\text { Data de operação: } 2016 \\
\text { Comprimento do cabo: } 10.556 \mathrm{~km} \\
\text { Capacidade de tráfego: } 64 \mathrm{~Tb} / \mathrm{s}\end{array}$ \\
\hline Monet & $\begin{array}{l}\text { Proprietárias: Angola Cables, Google, } \\
\text { Algar Telecom e Antel Uruguay } \\
\text { Data de operação: } 2018 \\
\text { Comprimento do cabo: } 11.000 \mathrm{~km}\end{array}$ \\
\hline BRUSA & $\begin{array}{l}\text { Capacidade de tráfego: não há } \\
\text { informações } \\
\text { Proprietária: Telefônica. } \\
\text { Data de operação: } 2017 \\
\text { Comprimento do Cabo: } 2.000 \mathrm{~km}\end{array}$ \\
\hline Tannat & $\begin{array}{l}\text { Capacidade de tráfego: } 90 \mathrm{~Tb} / \mathrm{s} \\
\text { Proprietárias: Google e Antel Uruguay }\end{array}$ \\
\hline
\end{tabular}

Backbone da Telebras no território brasileiro

Data de operação: 2018

South Atlantic Comprimento do cabo: $6.165 \mathrm{~km}$

Cabel System Capacidade de tráfego: $40 \mathrm{~Tb} / \mathrm{s}$

(SACS) Proprietária: Angola Cables

Data de operação: 2016

Comprimento do cabo: $10.556 \mathrm{~km}$

Capacidade de tráfego: $64 \mathrm{~Tb} / \mathrm{s}$

Algar Telecom e Antel Uruguay

Data de operação: 2018

Comprimento do cabo: $11.000 \mathrm{~km}$

Data de operação: 2017

_-_-_-_Comprimento do cabo: $390 \mathrm{~km}$

Capacidade de tráfego: $13 \mathrm{~Tb} / \mathrm{s}$

Proprietária: Google

Data de operação: 2017

Comprimento do cabo: $10.900 \mathrm{~km}$

Seabras-1 Capacidade de tráfego: $70 \mathrm{~Tb} / \mathrm{s}$

Proprietárias: Seabras Group, LLC

Data de operação: 2018

Comprimento do cabo: $5.900 \mathrm{~km}$

Capacidade de tráfego: $30 \mathrm{~Tb} / \mathrm{s}$

Proprietárias: Telebras e IslaLink

$\mathrm{Tb} / \mathrm{s}$ : terabits por segundo

Fonte: Igarapé Institute (2018). 
A tecnologia dos cabos transatlânticos para transporte de dados começa em 1858, para uso do telégrafo, por meio do cabo construído pela companhia Cyrus West Field, que ligava a Irlanda à ilha Terra Nova, Canadá e, a primeira transmissão de mensagens; em 1870, a rede de cabos se expandiu para o Oriente, da Inglaterra à Índia. Na década de 1940, os cabos submarinos foram transformados para uso de telefonia, com propriedade de empresas dos EUA. A tecnologia da fibra ótica surge em 1980, e seus cabos submarinos seguem frequentemente as mesmas rotas traçadas no fim do século XIX e início do XX (Mapa 2, Capítulo 1).

No decorrer do desenvolvimento das técnicas de transmissão de informações pela rede, a latência sempre foi um elemento fundamental, pois significa o tempo que um pacote de dados demora para ir de um ponto a outro. Depois de enviado, o pacote de dados é devolvido ao remetente, e o tempo de ida e volta é a chamada latência, ou ping.

Os problemas de transmissão por fibra óptica, wireless ou radiofrequência podem causar atrasos, que também dependem do tamanho do pacote, aumentando a latência no fluxo. A latência pode ser influenciada pelo congestionamento de rede e pela distância que o dado percorre. Por isso, conectar-se a servidores no Brasil ou perto do usuário final pode resultar em menos latência do que usar serviços no exterior, devido à distância dos cabos submarinos.

Ainda que haja uma latência de alguns milissegundos no envio ou no recebimento de dados para o usuário individual e isso tenha pouco impacto, o efeito conjunto de milhões de mensagens pode degradar o desempenho da rede, implicando mais tempo e uma potencial perda de informações (MALECKI; MORISET, 2008).

\subsection{A rede serviço que percorre a rede suporte}

A rede suporte da internet se estabelece efetivamente no começo da década de 1960, quando a rede de telefonia era dominante em todo o globo, pela operação de interligar computadores para que pudessem ser compartilhados entre usuários distribuídos em diferentes lugares. Três grupos de pesquisa - Instituto de Tecnologia de Massachusetts (MIT) e Rand Institute, dos EUA, e National Physical Laboratory, da Inglaterra - começaram a desenvolver uma tecnologia para envio de pacotes de informações entre os nós como alternativa aos dados de telefonia, sobretudo para atender à demanda de transmissão segura de voz por redes 
militares e criar o primeiro projeto de internet, o chamado ARPA (Advanced Research Projects Agency, ou Agência de Projetos de Pesquisa Avançada), nos EUA, como a primeira rede de computadores por comutação de pacotes, antecessora da internet atual.

A técnica de comutação de pacotes é o padrão de transmissão de dados pelo qual os pacotes, que são uma estrutura de transmissão de dados, são encaminhados e partilhados entre os nós da rede. Essa técnica reduz a latência e aumenta a fluidez e a velocidade da comunicação, sendo um ponto importante no desenvolvimento das tecnologias de transmissão de dados.

Em 1972, a ARPAnet era uma rede ainda limitada para atender organizações militares nos EUA: tinha aproximadamente 15 nós e gerou o primeiro protocolo, que foi tomado como modelo para o desenvolvimento da internet. Esses protocolos de comunicação são usados por todos os dispositivos que estão na rede para encaminhar dados como um conjunto de regras e convenções padronizadas que devem ser seguidas para permitir a troca de informações. $\mathrm{O}$ mais conhecido é o TCP/IP, que tem o principal conjunto de protocolos usados na internet: HTTP, HTTPS, IMAP, SMTP, IRC, POP, SMTP, IP, DHCP, TCP, TELNET e FTP.

Entre 1972 e 1980, surgiram outras redes que também adotavam a comutação por pacotes, por ondas eletromagnéticas, por satélite e por rádio, principalmente nos EUA, na Inglaterra e na França. No mesmo período, foram desenvolvidas as primeiras aplicações como o e-mail.

Nessa década, a arquitetura das redes se expandiu e passou a conectar mais redes, ainda financiada por departamentos de defesa e militares como a Defense Advanced Research Projects Agency (Darpa) ou Agência de Projetos de Pesquisa Avançada de Defesa dos EUA, criando efetivamente uma rede de redes com protocolos para se intercomunicarem, o mencionado TCP/IP.

No fim da década de 1980, o número de computadores ligados à internet pública alcançou cem mil unidades, ligando principalmente universidades de vários pontos do globo, com mais densidade em países como EUA, França, Alemanha e Inglaterra. Ao mesmo tempo, desenvolveu-se o sistema de nomes de domínios chamado DNS, usado para simplificar o nome dos sites. Na França, teve início o chamado projeto Minitel, de conexão de residências a redes de dados, quando o Estado forneceu, gratuitamente um terminal de acesso a toda residência francesa, com sites de livre acesso como lista telefônica e sites particulares, com 
cobrança de taxa de cada usuário por tempo de uso. No começo de 1990, o Minitel oferecia mais de 20 mil serviços, como home banking e bancos de dados especializados para pesquisa. Era usado por cerca de $20 \%$ da população francesa, gerando uma receita de mais de um bilhão de dólares e criação de dez mil empregos (KUROSE, 2010); foi a primeira experiência de uso público da internet no mundo.

Em termos de rede de serviços, o principal evento da década de 1990 foi a criação da World Wide Web (WWW), que popularizou a internet conectando residências e empresas e fomentou também a capilarização de redes suporte pelo território. A WWW serviu como plataforma para habilitar e disponibilizar inúmeras aplicações como negociação de ações, capitais e serviços bancários on-line, serviços multimídia em tempo real e serviços de armazenamento de informações, consolidando, a partir dessas novas técnicas, a simultaneidade planetária.

A criação do navegador ${ }^{30}$ Mosaic em 1993, desenvolvido na Universidade de Illinois, EUA, foi uma técnica importante para o uso da WWW, pois tinha possibilidade de interfaces gráficas. Até então, os gráficos eram visualizados junto aos textos das páginas web.

A WWW foi criada no European Center for Nuclear Physics (CERN), ou Centro Europeu de Física Nuclear, em 1991, e, com a demanda das empresas por transmissão de dados, os servidores começaram a fazer transações comerciais mais intensamente em 1996, quando a Microsoft começou a criar navegadores estimulando corporações e novas empresas a criarem mais produtos e serviços para a internet. Desenvolve-se aí o correio eletrônico (email), que então passa a incluir anexos, além do comércio on-line, serviços de mensagem instantânea como o ICQ e do compartilhamento peer-to-peer ${ }^{31}$ de arquivos MP3.

Entre 1995 e 2001, aumentou sensivelmente a participação dos mercados financeiros na internet, que começaram com ofertas públicas de ações a serem negociadas em bolsas de valores; nesse contexto, muitas empresas eram avaliadas em bilhões de dólares sem ainda ter nenhum fluxo significativo de receita. Essa especulação resultou em muitas falências, e

\footnotetext{
${ }^{30} \mathrm{O}$ navegador (ou browse, em inglês) é um programa ou aplicativo que, instalado num computador ou smartphone, dá acesso a sites. Depois do Mosaic, surgiram, por exemplo, Netscape, Internet Explorer, Safari, Fire Fox, Opera, Chrome, Android Browser e Mozilla.

${ }^{31}$ Peer-to-peer é uma arquitetura de redes de computadores na qual cada um dos pontos ou nós funciona tanto como cliente quanto como servidor, permitindo o compartilhamento de serviços e dados sem a necessidade de um servidor central.
} 
algumas empresas se consolidaram na produção de aplicações e como grandes corporações conhecidas até hoje: Microsoft, Cisco, Yahoo, Apple, Google, Amazon etc.

A web é a aplicação da internet que se popularizou pelo tipo de interação entre as pessoas e a rede de dados, visto que, a partir daí, os usuários a acessam de forma interativa, diferentemente da transmissão de rádio ou de televisão, em que o indivíduo só sintoniza o aparelhos quando o provedor disponibiliza o conteúdo. $\mathrm{Na}$ web, os usuários podem disponibilizar informações e também pesquisá-las, além de os dispositivos gráficos estimularem os sentidos, pois oferecem agora muitas interfaces com inúmeros materiais de vídeo e áudio a que se tem acesso por demanda.

$\mathrm{Na}$ história humana, os objetos estão sempre mudando de significado com o movimento das sociedades (SANTOS, 2000a, p. 34), e, no período atual, existe a possibilidade de conhecer o planeta extensiva e profundamente, pois os objetos são concebidos, produzidos e usados para o conhecimento do mundo em sua totalidade e nas particularidades dos lugares, como as condições físicas, naturais ou artificiais, econômicas, sociais e políticas. Esse fato deve-se ao progresso da técnica, que deriva do progresso das ciências. Na contínua busca de mais-valia, as empresas valorizam diferentemente os lugares para implantar ou não seus sistemas; assim, a cognoscibilidade do planeta é um dado essencial também à operação das empresas e à produção do sistema histórico atual.

Conhecer e entender o planeta permitem a implantação e o funcionamento do grande sistema de engenharia materializado na internet. Ele tem bilhões de dispositivos conectados: além de smartphones, computadores e tablets, dispositivos como sensores, webcams, eletrodomésticos etc. Esses dispositivos, mais especificamente o smartphone, são denominados sistemas finais, conectados por várias ligações para transmitir informações e dados pelo compartilhamento de pacotes entre nós da rede.

Para que se encadeie esse sistema de objetos, há vários elementos que articulam a comunicação e que são compostos de diferentes tipos de meios físicos como os cabos coaxiais usados para transmitir sinais, espectro eletromagnético, fios de cobre e fibras óticas. Diferentes enlaces transmitem dados em velocidades diferentes (medida em bits por segundo): na Figura 6, os elementos se comunicam por vários tipos de enlace, em que cada um dos objetos técnicos denominados sistemas finais, como o smartphone, acessam a internet por meio de provedores de serviços de internet (ISP, sigla do inglês internet service provider), 
que podem ser residenciais, como as empresas de TV a cabo ou de telefonia, corporativos, de universidades e centros de pesquisa e aqueles que dão acesso sem fio em aeroportos, hotéis, cafés e espaços públicos. Cada ISP é composto por uma rede de comunicação complexa e híbrida, constituída de humanos e não humanos.

Figura 6 - Principais estruturas da rede suporte para conexão à internet

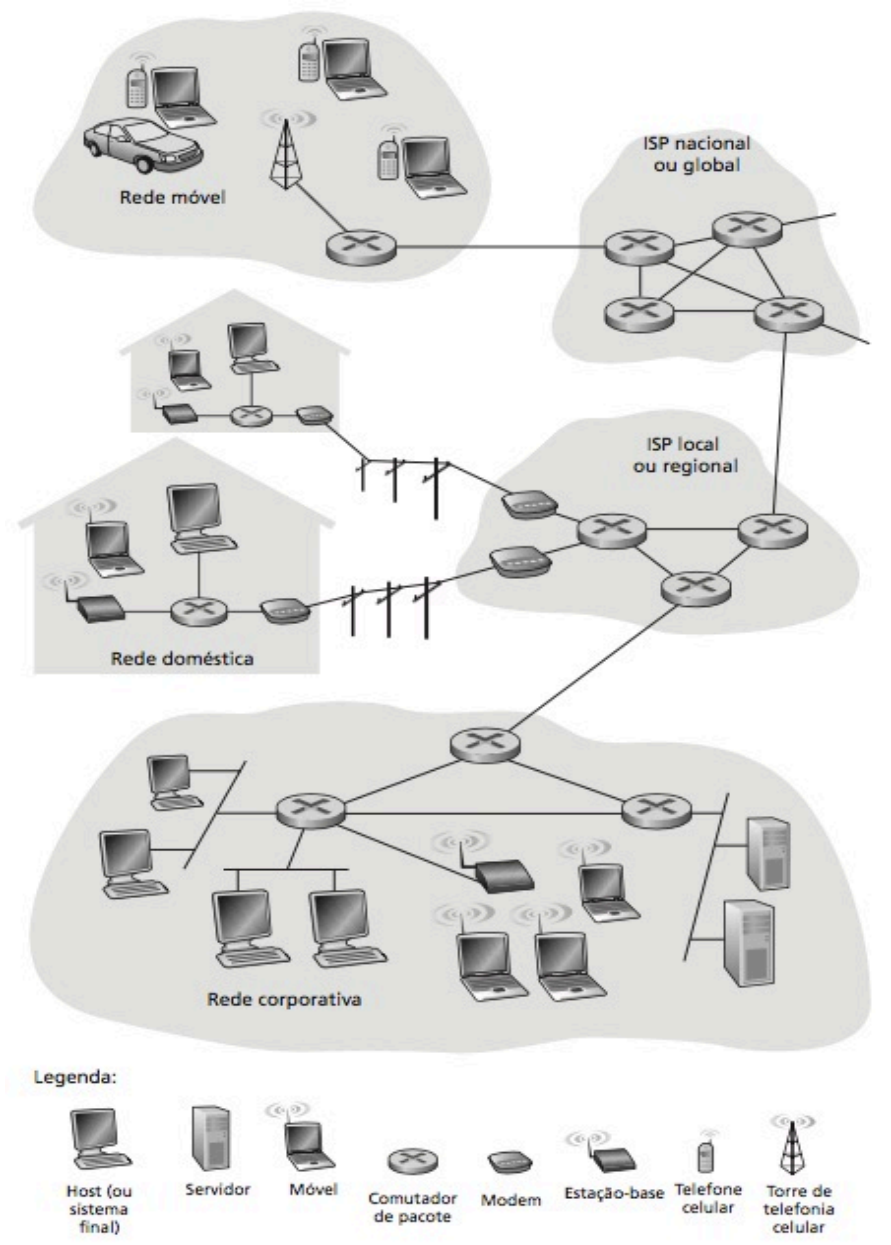

Fonte: Kurose (2010, p. 260).

Os ISP provêm vários tipos de conexão, por cabo ou sem fio, e podem atuar em vários níveis, desde provedores locais ou regionais até nacionais ou globais.

Assim, a rede serviço fornece as aplicações que são frequentemente usadas por meio de smartphones como e-mail, conexão à web, mensagens instantâneas, vídeos em tempo real, jogos on-line, compartilhamento de arquivos, televisão, login remoto etc. Nessa camada da internet, essas aplicações são conhecidas como aplicações distribuídas (KUROSE, 2010), pois abrangem diversos sistemas finais, ou seja, dispositivos como o smartphone e que trocam informações mutuamente. Essa constituição fundamental da rede é notada quando se realça a 
escala de seu funcionamento. O bit, sua unidade elementar, sai de um sistema final, transita por variados enlaces e roteadores e chega a outro sistema final, e esse bit é transmitido inúmeras vezes (KUROSE, 2010, p. 278). Logo, da origem ao destino, o bit passa por uma série de pares transmissores-receptores constituídos de elementos humanos como, por exemplo, profissionais técnicos e de serviço, e não humanos, que são os dispositivos que recebem informações por meio de ondas eletromagnéticas ou pulsos óticos como pares de fios de cobre trançados, ${ }^{32}$ cabos coaxiais, ${ }^{33}$ cabos de fibra ótica, espectro eletromagnético e satélites, por exemplo.

A rede suporte e a rede serviço têm um papel importante na abordagem das redes geográficas pois constituem uma tipologia. Esses dois tipos de redes se articulam e uma define a outra, permitindo entender como as redes se transformam. O uso do smartphone, que requer infraestruturas especializadas também demandam serviços especializados capilarizados, como as operadoras de internet móvel e fixa, assistência técnica de software e hardware, atendimento ao cliente etc. Logo, a difusão social e espacial dessa rede depende da capilarização tanto da infraestrutura quanto dos serviços, como por exemplo o condicionamento da implantação das ERB pelo aluguel da área, como os topos dos prédios.

Nesse contexto, a criptografia é um sistema de segurança com que uma rede serviço codifica os dados transmitidos pelos usuários para que só determinado destinatário possa lêlos. Assim, se os dados forem interceptados durante a transmissão, a mensagem não pode ser lida, pois só quem está habilitado a recebê-los tem uma "chave" definida para decodificá-la. No momento de compartilhamento de informações, os dados ficam armazenados e disponíveis para o provedor de serviços que faz essa intermediação. Contudo, eles podem estar visíveis para outros agentes que transportam pacotes de dados e fluxos supostamente privados e, assim, ser interceptados.

Quando a internet começou a operar no Brasil, as companhias de comunicação deveriam fornecer os dutos para montar e efetivar a rede suporte. Na década de 1980, a RNP alugava canais da Embratel, isto é, a infraestrutura como o duto levando a conexão até o usuário final; não havia interesse no fluxo da rede serviço que passaria por ali, e esse era o

\footnotetext{
$32 \mathrm{O}$ par de fios de cobre trançado é usado há cerca de um século em redes de telefonia, conectando aparelhos telefônicos a centrais locais, e hoje, para acesso residencial à internet.

${ }^{33} \mathrm{O}$ cabo coaxial é constituído de dois condutores de cobre e pode alcançar altas taxas de transmissão em bits por segundo; é comumente utilizado em sistemas de televisão a cabo e pode ser conectado a vários tipos de dispositivo.
} 
modelo de contratação da banda. A chamada banda larga é a conexão do de alta velocidade. A diferença entre o acesso discado e a banda larga é a velocidade de conexão, e a largura da banda é a medida da capacidade de transmissão de determinado meio, conexão ou rede, definindo a velocidade com que trafegam os dados.

A velocidade dessas bandas tem um componente estatístico: ainda que se proponha entregar $10 \mathrm{MB}$ a muitos usuários, não é possível prover esse volume de dados a todos ao mesmo tempo; por isso; há uma média de expectativa de uso. $\mathrm{O}$ acesso do smartphone à internet não é capaz de garantir a velocidade da banda, pois muitos usam um grande fluxo e as estações rádio base, daí os limites de dados transmitidos. As operadoras não os geram, apenas os transportam, e também não têm custos diretos pelo aumento da capacidade, pois, ainda que busquem informações e dados fora da área do sistema e possam justificar os custos pelo aumento do uso, existem técnicas sofisticadas que mantêm os conteúdos mais acessados mais próximos da "cabeça" das operadoras, isto é, no centro de distribuição. Por exemplo, os filmes que se assistem no Brasil pelo aplicativo ou site Netflix vêm do próprio sistema da operadora, que tem um nó no território nacional, e não nos EUA ou na Europa, como nos primórdios da internet. No período atual, o acesso a multimídias como filmes, imagens ou vídeos, por exemplo, seria muito mais caro se fosse remoto e sofreria atraso na entrega.

A má qualidade da banda larga e do acesso à internet em muitas porções do território brasileiro se deve à não expansão da rede suporte, principalmente dos cabos de fibra ótica, que podem ser instalados sob o solo, mares ou rios. As metrópoles abrigam a maior parte das fibras com velocidades melhores (Mapas 7 a 10). Nesses termos, há imensas disparidades de acesso entre os grandes centros urbanos e lugares isolados, pois estes não oferecem contrapartida às operadoras, que não têm interesse em investir onde não há atrativo comercial. Por isso, a expansão das redes é uma questão de políticas sociais e de direito à comunicação.

Além do problema de distribuição e funcionamento dessas redes no território, há um que envolve o controle do volume de bits que passam por esses cabos de fibra ótica. Se a cobrança se baseasse num metrônomo, que mede em bits os fluxos transmitidos, as empresas não poderiam mais divulgar seus anúncios, que custariam muito aos consumidores, e, assim, também não investiriam da atualização ou na criação de novos aplicativos. 
Assim, o uso da internet não deve ser cobrado segundo o modelo de consumo de água e luz, pois seus geradores são remunerados e as estruturas têm custo fixo (GETSCHKO, 2017). A estrutura é calculada pelo número de habitantes, e não é proporcional ao uso que se faz dela; portanto não se pode aplicar o mesmo modelo aos dois casos. Há que considerar que uma parte importante da economia da internet se baseia nos dados que se captam dos usuários, muitas vezes sem que estejam cientes do que estão dispondo.

Mapa 7 - Presença e velocidade da rede de banda larga na região Sul, Brasil, 2018

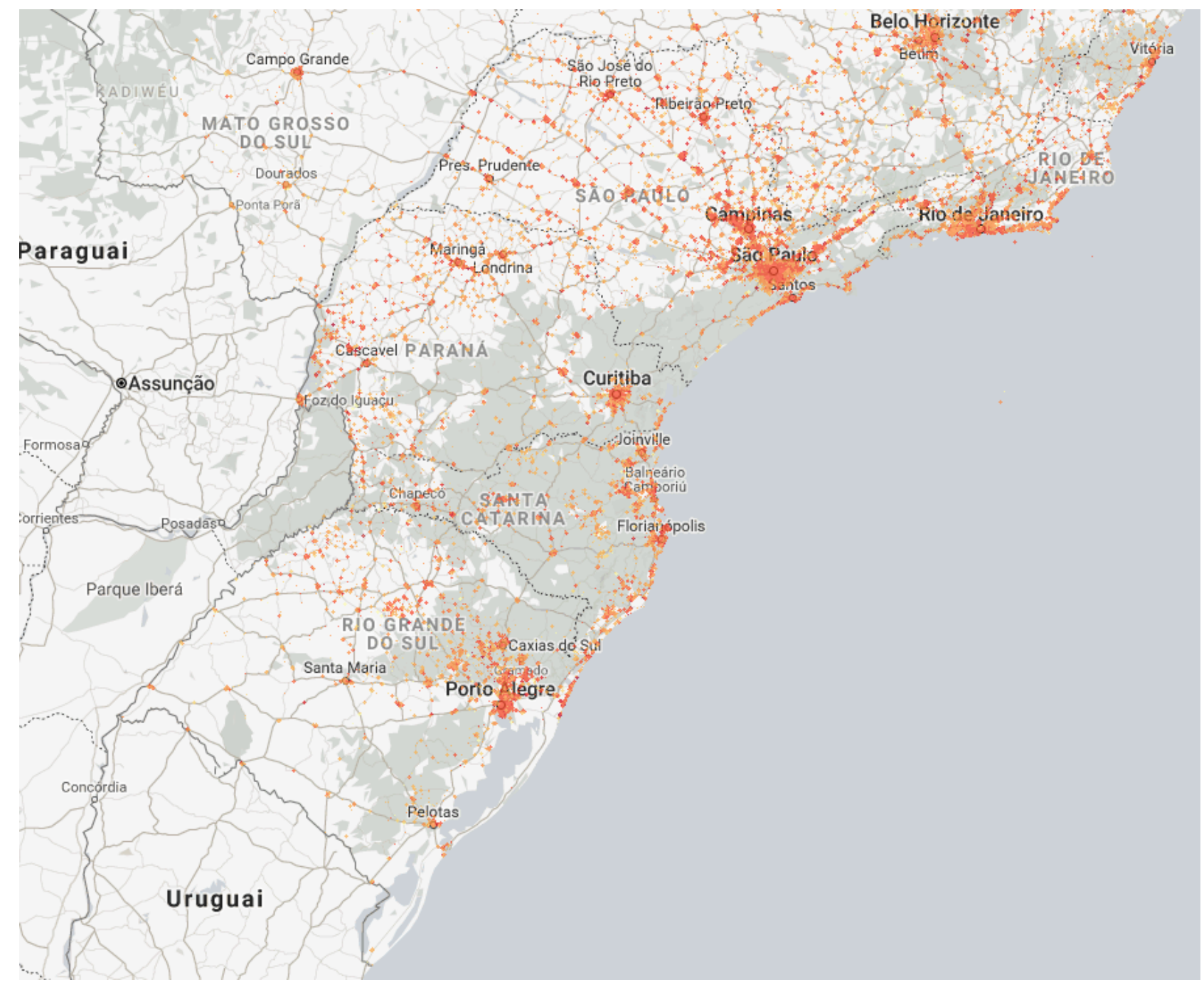

Legenda:

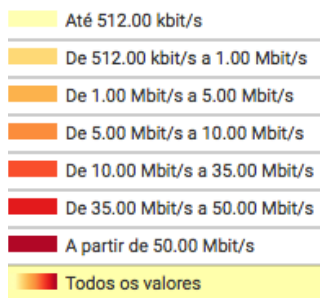

Fonte: Simet (2018). 
Mapa 8 - Presença e velocidade da rede de banda larga nas regiões Sudeste e Centro-Oeste, Brasil, 2018

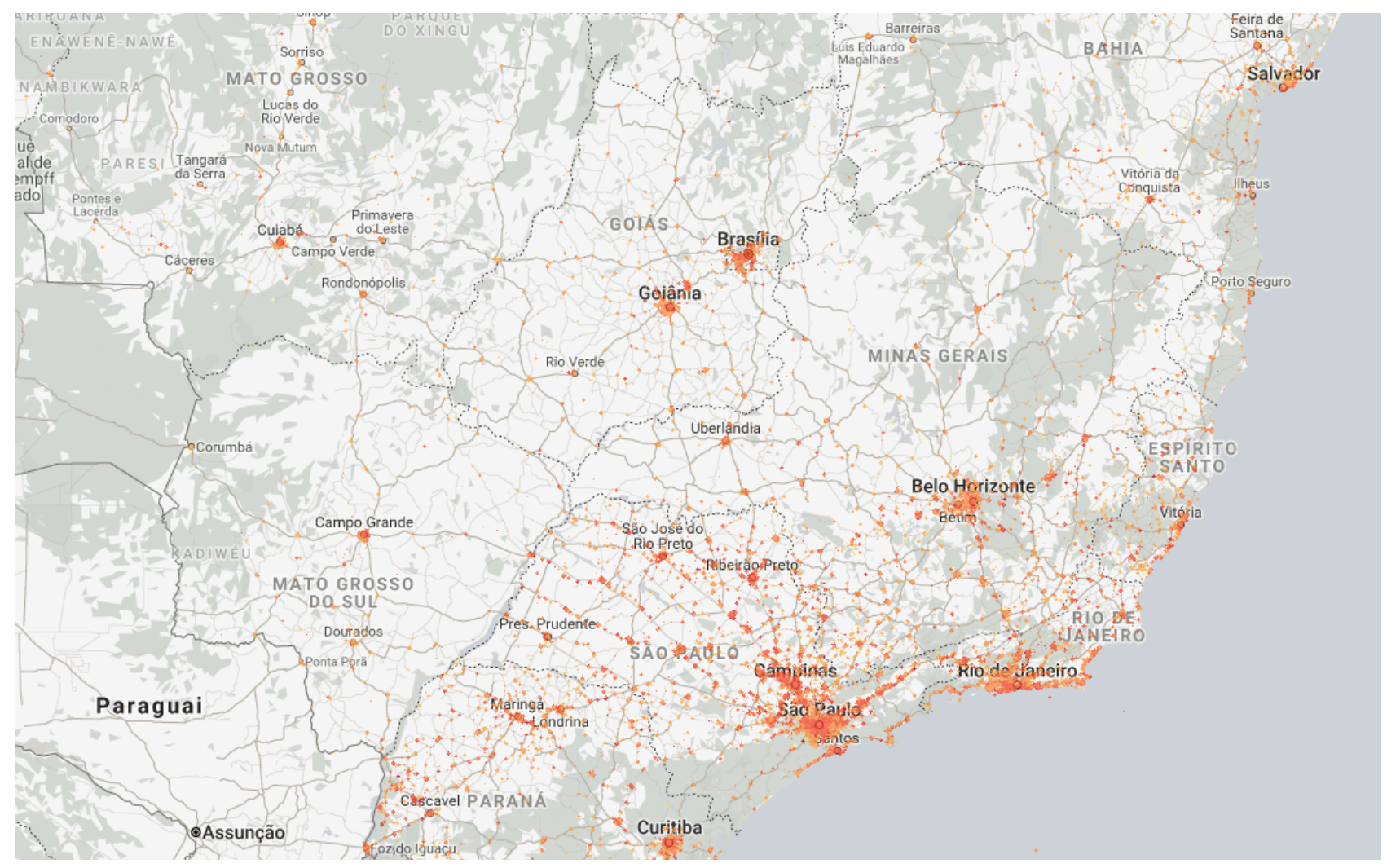

Legenda:

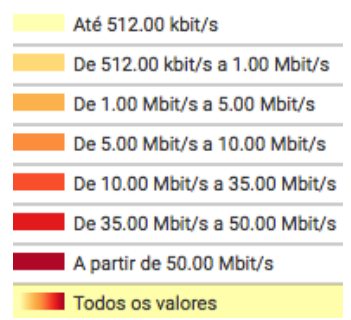

Fonte: Simet (2018). 
Mapa 9 - Presença e velocidade da rede de banda larga na região Nordeste, Brasil, 2018

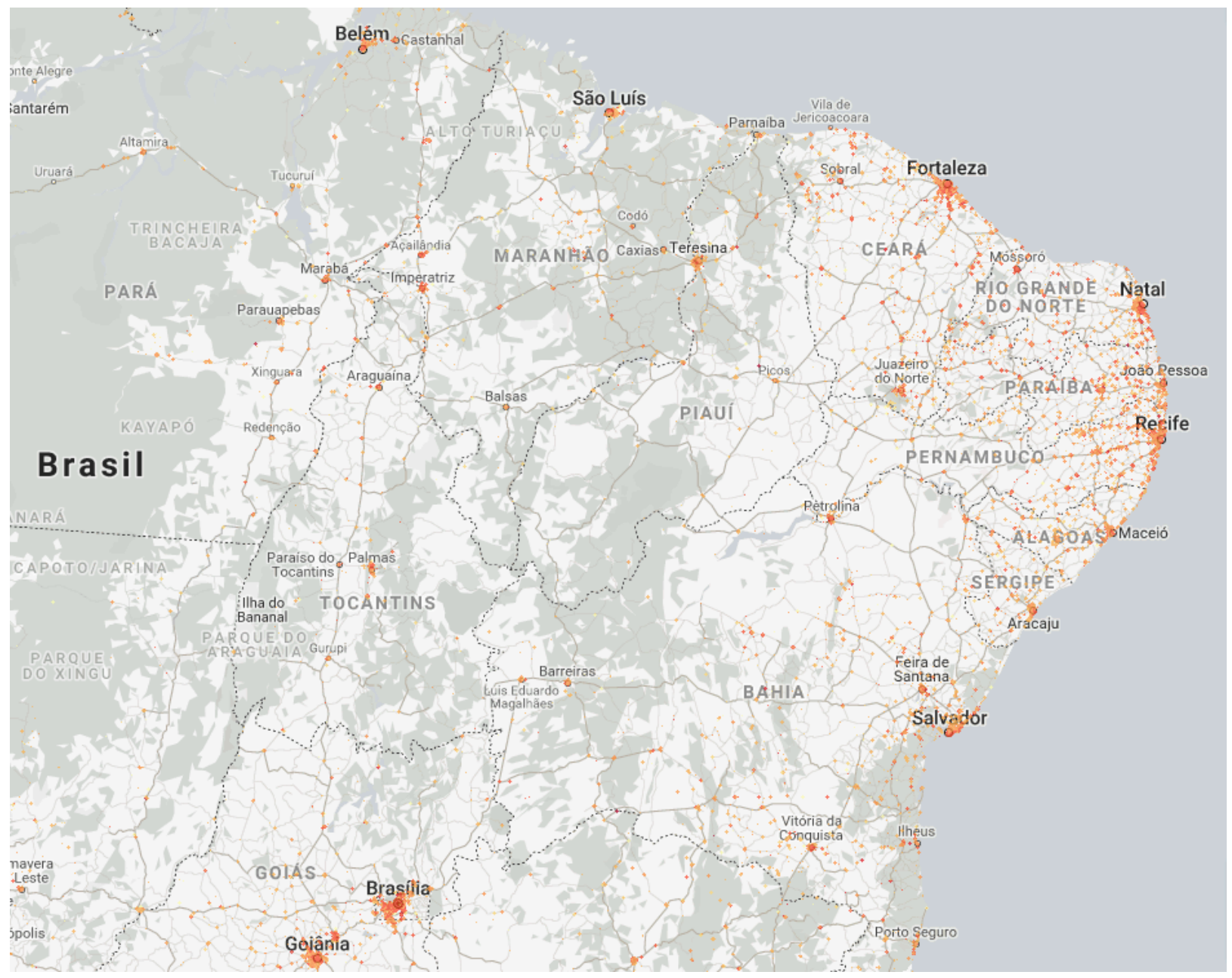

Legenda:

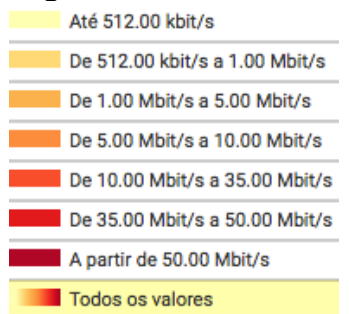

Fonte: Simet (2018). 
Mapa 10 - Presença e velocidade da rede de banda larga na região Norte, Brasil, 2018

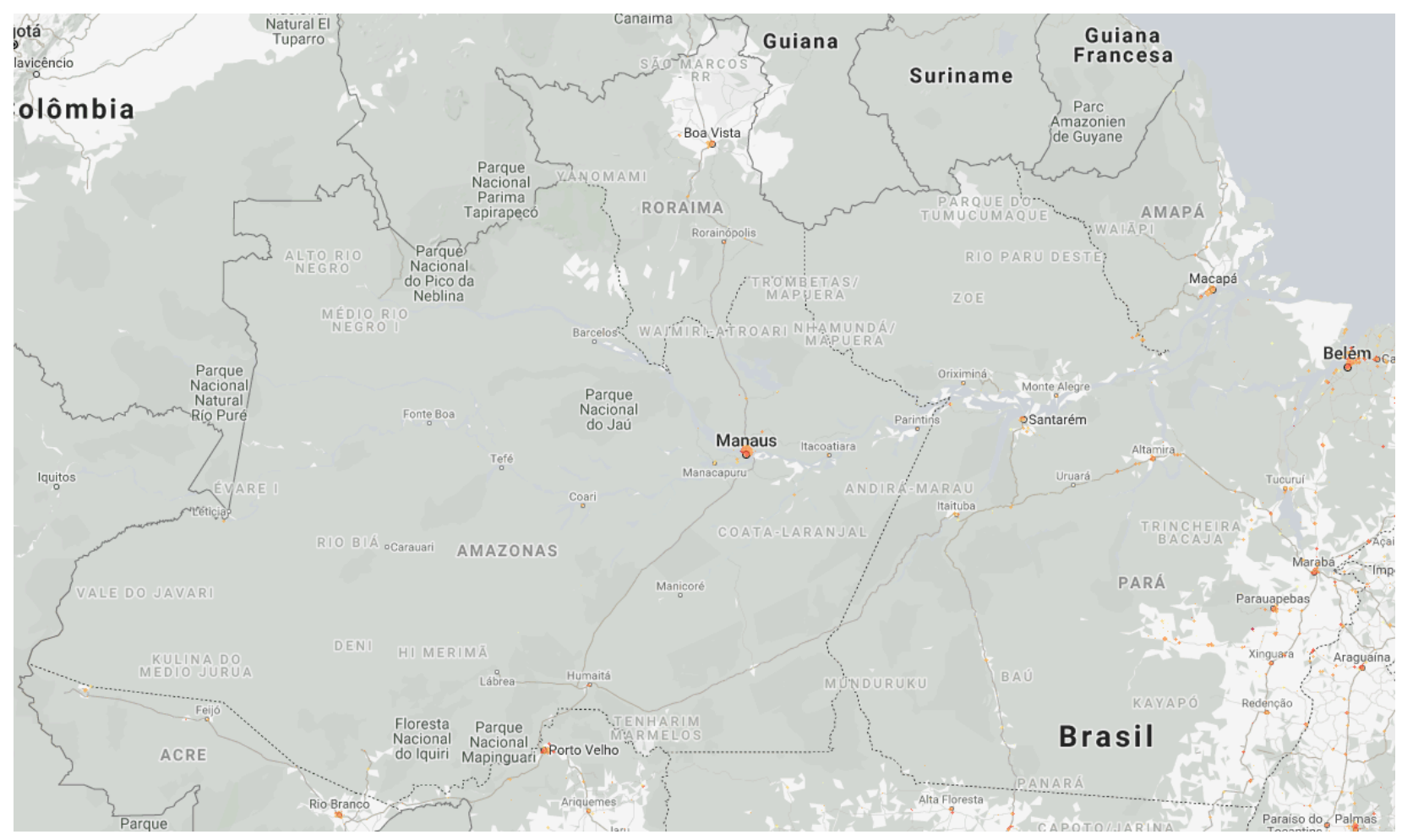

Legenda:

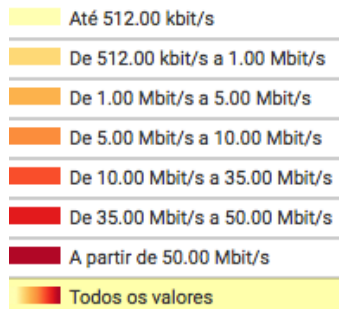

Fonte: Simet (2018). 


\subsection{Capilarização das ERB no território}

A capilarização informacional promovida pelo smartphone no território se apoia em infraestruturas da rede suporte chamadas ERB. Conhecidas popularmente como antenas, é a denominação do sistema de telefonia celular da estação fixa com que se comunicam os terminais móveis (Figura 7).

Figura 7 - Funcionamento de uma ERB

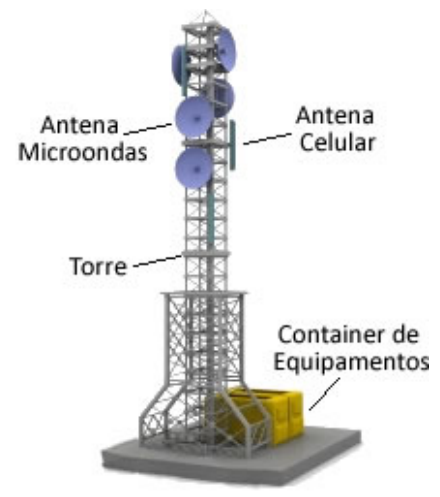

Fonte: Telebrasil (2016).

Esse sistema para conexão à internet funciona, primeiramente, na comunicação do smartphone com a ERB mais próxima, que encaminha a chamada telefônica à central de comutação e controle (CCC). Dependendo do destino, a chamada é encaminhada a outra CCC ou a uma ERB, que se comunica com o smartphone a que se destina a chamada (Figura 8). A área de cobertura de uma ERB é a chamada célula.

Figura 8 - Comunicação do smartphone com a ERB

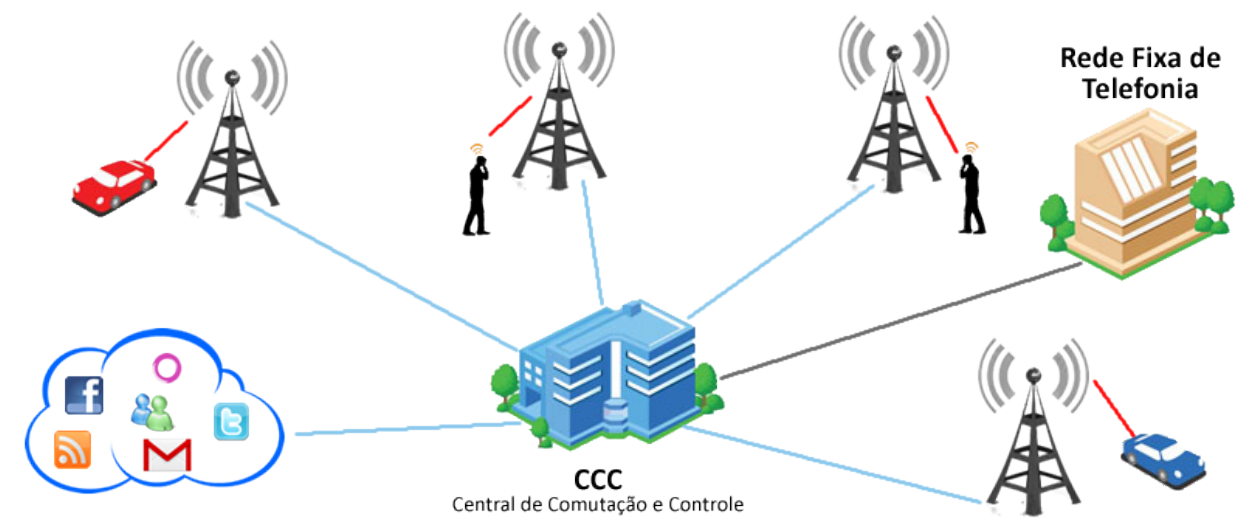

Fonte: Telebrasil (2016). 
Há ERB nos centros urbanos de todo o planeta, mais intensamente a partir dos anos 2000 (STEINBERGER; TOFETI, 2015). A presença desses sistemas técnicos aumentou nas cidades, e seu número cresceu exponencialmente em função do desenvolvimento das tecnologias da informação, sobretudo com o advento e o uso banalizado do smartphone. No Brasil, o ano de 2004 é considerado um primeiro marco da telefonia celular, quando o número de linhas telefônicas móveis ultrapassou as fixas (ANATEL, 2016). Em 2012, há o segundo marco, quando o número de aparelhos ultrapassou a população, alcançando a teledensidade (STEINBERGER; TOFETI, 2015). Há, em média, 132 celulares para cada 100 habitantes, o que comprova sua popularização.

Para atender a essa crescente demanda de acesso mais rápido à rede serviço, foi necessário instalar um grande número de ERB nos centros urbanos, onde se concentra a maioria dos usuários. Isso pressionou pela expansão da rede suporte e, assim, verifica-se a inseparabilidade entre smartphone e ERB, objetos que configuram um sistema que compõe o meio técnico-científico-informacional (SANTOS, 1994). Esse meio é a expressão espacial da globalização, intensificada a partir da década de 1990, quando a informação e os sistemas comunicacionais vão adquirindo importância ao longo dos períodos, que são sucessões de sistemas técnicos.

A cada período corresponde determinada família de técnicas (SANTOS, 1994); no período técnico-científico-informacional, os sistemas técnicos de comunicação permitem ações que podem ser propagadas em conjunto, ao contrário de períodos passados, quando "a propagação de diferentes variáveis não era necessariamente acelerada" (SANTOS, 1997, p. 27). A velocidade e a crescente incorporação de novos fixos e fluxos ao território dispersam e capilarizam os sistemas técnicos de comunicação e informação, o que permite a simultaneidade dos lugares e dos tempos.

Assim, o smartphone é produto e, ao mesmo tempo, produz o meio técnico-científicoinformacional, viabilizando trocas materiais e de informações por uma série de novos agentes, que impõem novas dinâmicas organizacionais ao território. No atual período, verifica-se um “alargamento dos contextos", caracterizado por;

[...] novas possibilidades de fluidez que estão na base dessa formidável expansão do intercâmbio. Aumenta exponencialmente o número de trocas, e estas ocupam um número superlativo de lugares em todos os continentes, multiplicando-se o número e a complexidade das conexões. Estas passam a cobrir praticamente toda a superfície da Terra (SANTOS, 1997, p. 202). 
O desenvolvimento e a implementação das técnicas, que são um híbrido de materialidade e intencionalidade, transformam o território e, a partir do alargamento dos contextos, os sistemas de objetos se distribuem territorialmente; assim, os sistemas produtivos mais complexos também difundem suas diferentes etapas produtivas, em razão das redes informacionais hoje presentes em vários pontos do território.

Portanto, a relação entre a população residente e o número de smartphones e de ERB é um indicador importante para avaliar esses objetos e sua repercussão territorial. Por meio da rádio freqüência, as ERB também podem identificar os dispositivos e, consequentemente, seus usuários. Dada a demanda crescente por conexão, aumenta o número de ERB instaladas em lugares onde há mais solicitações de acesso, como grandes centros de compras e shopping centers e também em aeroportos.

\subsection{Espectro eletromagnético para conexão de smartphones: 2G, 3G, 4G}

Para ser eficiente, a conexão do smartphone às redes $2 \mathrm{G}, 3 \mathrm{G}, 4 \mathrm{G}$ ou, em breve, 5G, que passam por ERB, deve ter velocidade alta e prover mobilidade ininterrupta, possibilitando a conexão ainda que o usuário esteja em movimento, inclusive num meio de transporte rápido. A letra $\mathrm{G}$ indica a geração de cada uma dessas redes: as mais antigas, projetadas apenas para tráfego de voz, tinham sistema analógico de primeira geração $(1 \mathrm{G})$, foram substituídas pelos sistemas 2G. A segunda geração também foi projetada para voz e se desenvolveu para suportar dados para conexão à internet. Os sistemas 3G também suportam voz e dados e ainda têm capacidade para velocidades mais altas, que se desenvolveu nos $4 \mathrm{G}$, com menos latência e mais capacidade, por utilizar cabos de fibra ótica em sua comunicação com as ERB.

Os usuários também podem se deslocar sem perder a conexão porque, da perspectiva da camada da rede, eles podem ser associados ao mesmo ponto de acesso, independentemente de sua localização. O uso da internet móvel por smartphone permite que a identificação do dispositivo permaneça a mesma quando ele transita entre duas provedoras de rede de telefonia móvel. As aplicações do smartphone, sejam web ou aplicativos, devem conhecer o endereço IP de conexões móveis e não móveis.

Tendo começado a operar no início dos anos 1980, o 1G, a rede de primeira geração, funcionava por sinais analógicos, com ondas frequentes, sem criptografia e em baixa 
velocidade. Essa tecnologia dependia de modem externo acoplado ao aparelho para realizar a troca de dados, com velocidade de download e upload sempre inferior a $10 \mathrm{~Kb}$ por segundo. Outra característica era sua incompatibilidade com os dispositivos, pois as primeiras redes móveis de celular não eram padronizadas entre os fabricantes, o que prejudicava os usuários que mudavam de país e esmo de região.

Na década de 1990, a tecnologia de segunda geração, o 2G - também conhecida como global system for mobile communications (GSM), ou sistema global de comunicação móvel -, podia levar dados em pacotes, criptografados, mas com baixa velocidade. Foi a tecnologia responsável pela padronização da telefonia móvel com criptografia digital, o que a tornou mais eficiente e levou à expansão da telefonia móvel, posto que permitia o download de $e$ mails para celulares, por exemplo.

A rede general packet radio service (GPRS), ou serviço de rádio de pacote geral, é considerada de 2,5G, com algum aprimoramento das taxas de transferência de dados, funcionalidades como o uso simultâneo de dados e voz e acesso imediato e permanente à rede de dados. Essa tecnologia também passou a ser usada para operações em caixas bancários eletrônicos.

Essa geração se incrementou com o aumento da velocidade para o usuário final de 32 Kbps para $80 \mathrm{Kbps}$ com a tecnologia chamada enhanced date rates for GSM evolution (EDGE), ou taxas de dados ampliadas para a evolução do GSM. Ela também é denominada 2,75 G, e, quando um smartphone se conecta a essa rede, aparece na tela o sinal E.

No Brasil, ainda está em uso uma densidade de infraestruturas de redes 2G: smartphones com pacotes de dados $3 \mathrm{G}$ podem aparecer conectados à rede EDGE, pois, em caso de tráfego intenso em determinada rede de uma operadora, esta "recua" o usuário para a rede anterior. Às vezes, o smartphone pode estar conectado a uma rede $3 \mathrm{G}$ e, se naquele momento não houver "vaga" naquela rede, a dita "queda de sinal", a conexão volta para a rede $2 \mathrm{G}$, que funciona como uma "área de reserva". No Brasil, as redes GSM, GPRS e EDGE usam a faixas de frequência de $850 \mathrm{MHz}$ ou de 900 a $1.800 \mathrm{MHz}$.

A terceira geração, o 3G, funciona como um replicador: o smartphone pede sinal a uma antena, que pede à operadora central. Tornou-se a conexão à internet mais eficiente para o uso de redes sociais, e se banalizaram os aplicativos com a comunicação por vídeo, o e-mail 
e o download e upload de mídias e mensagens instantâneas, com possibilidade de chegar a megabits por segundo $(\mathrm{Mb} / \mathrm{s})$.

Essa terceira geração não usa a mesma frequência de rádio da segunda $(2 \mathrm{G})$, e ainda há muitas áreas do território brasileiro com pouco ou nenhum acesso à rede $3 \mathrm{G}$, cuja cobertura é 19\% menor do que a média global (OPEN SIGNALE, 2018), e uma velocidade menor inviabiliza a utilização integral das aplicações do smartphone. Sob o sinal 3G, cada ERB pode suportar de 60 a 100 conexões simultâneas e usa a faixa de frequência de $850 \mathrm{MHz}$ ou entre $1.900 \mathrm{MHz}$ e $2.100 \mathrm{MHz}$.

A rede mais recente é a quarta geração, $4 \mathrm{G}$, que começou a ser instalada em meados de 2012 e, diferentemente das anteriores, tem antenas de transmissão menores e produz um sinal mais denso, sustentando cada uma de 300 a 400 telefones ao mesmo tempo. Essa rede pode operar em duas faixas de frequência: $700 \mathrm{MHz}$ e 2,5 GHz.

O 4G foi implantado no Brasil na faixa de 2,5 GHz, pois a de $700 \mathrm{MHz}$ ainda servia a sinais de televisão analógica, resultando numa propagação mais difícil do sinal. Em vários países europeus e nos EUA, as antenas de $700 \mathrm{MHz}$ são as mais usadas pela rede 4G, pois, por sua potência, demandam quatro vezes menos ERB do que as de 2,5 GHz.

Um fato interessante a esse respeito é a não padronização do Brasil com outros países, o que acarretou problemas no evento da Copa Mundial de Futebol, em 2014: turistas do exterior não conseguiam se conectar à rede $4 \mathrm{G}$ com aparelhos que funcionavam em frequência $700 \mathrm{MHz}$, levando à implantação de algumas antenas com essa frequência nas cidades que sediaram os jogos da Copa. A frequência de $700 \mathrm{MHz}$ é mais adequada à transmissão de dados, pois é mais estável e mais densa, capazes de transpor obstáculos como prédios; já as frequências mais altas podem ser barradas por prédios, muros ou outras barreiras físicas.

A principal característica do funcionamento do $4 \mathrm{G}$ é a conexão da ERB com a central por cabo de fibra ótica, aumentando a velocidade e o uso da tecnologia chamada long term evolution (LTE), ou evolução de longo prazo, que dá prioridade ao tráfego de dados em detrimento do de voz, o que a torna mais rápida e estável. Em condições normais de funcionamento, a latência da rede chega a, no máximo, 30 milissegundos, e a conexão é mais estável, desde que o usuário esteja a uma velocidade de até $500 \mathrm{~km} / \mathrm{h}$. 
No Brasil, as infraestruturas da rede $4 \mathrm{G}$ usam os equipamentos da $3 \mathrm{G}$ para transmitir os dois padrões, diferindo apenas na última etapa da conexão: o sinal do smartphone chega às operadoras por cabos de fibra ótica, com um método de organização de dados mais veloz, sinal mais rápido e mais informações, além de uma tecnologia que identifica a intensidade do tráfego e reorganiza dados para não sobrecarregar o sistema como um todo.

Para todos esses tipos de rede e seu desenvolvimento técnico, o espectro eletromagnético é o meio indispensável, por onde se transportam as frequências. As diferentes frequências são separadas conforme o comprimento de onda e agrupadas em zonas chamadas espectros.

Essa técnica é usada para a comunicação de serviços públicos como polícia e ambulâncias e para as telecomunicações: a voz e os dados da internet sem fio usam frequências diferentes. Tratado como mercadoria pelas empresas operadoras de telefonia celular e também por canais de televisão e estações de rádio, o espectro usam frequências predeterminadas. ${ }^{34}$

O espectro eletromagnético tem limitações físicas, e há interferências quando se usam dois canais próximos emitindo sinais de mesma frequência. Por esse motivo, a Agência Nacional de Telecomunicações (Anatel) regula o seu uso e delibera sobre como e quanto de cada faixa de frequência cada operadora pode explorar.

Os serviços móveis demandam cada vez mais o uso do espectro eletromagnético, e, como um meio limitado e propriedade física da luz que é dividido em bandas, é usado de várias formas como na compactação de informações pelo sinal digital, convertendo o sinal analógico em digital para ampliar o tráfego simultâneo de dados nessas frequências sem interferência.

\footnotetext{
${ }^{34} \mathrm{VHF}$ (very high frequency) designa frequências muito altas, na faixa de $30 \mathrm{MHz}$ a $300 \mathrm{MHz}$, usadas pelas rádios FM e pela televisão aberta, do canal 2 ao 13. UHF (ultra high frequency) designa frequências ultra-altas, na faixa de $300 \mathrm{MHz}$ a $3.000 \mathrm{MHz}$, usadas por empresas de telefonia celular e alguns canais da televisão aberta. SHF (super high frequency) designa frequências superaltas, na faixa de $3 \mathrm{GHz}$ a $30 \mathrm{GHz}$, usadas pelos satélites das banda $\mathrm{C}$ e $\mathrm{Ku}$, que transportam sinais de televisão aberta com conexão internacional, sinais de telefonia e dados.
} 


\subsection{Outras redes que capilarizam a informação no território pelo uso do smartphone e pela conexão à internet}

No âmbito da rede suporte, além das tecnologias que são tradicionalmente implantadas e que usam cabos de fibra ótica e ERB, por exemplo, há sistemas técnicos que fazem conexões por outros meios. Atualmente, as corporações Google e Facebook desenvolvem e implantam tanto a rede suporte quanto a rede serviço, em consequência da demanda por conexão, reforçando o movimento de uso crescente e banalizado dos smartphones, com o objetivo de expandir também suas redes serviço, revelando os delineamentos do conteúdo e do controle de informações. Ressaltamos que essas empresas não explicam a totalidade da internet, pois há inúmeras redes exclusivas (de governos, da National Aeronautics and Space Administration - NASA, de corporações, bancos etc.), e que não são abordadas aqui.

A estratégia contemporânea do Facebook é implantar redes suporte e capilarizar suas redes serviço, dada pela rede social de mesmo nome e pela plataforma WhatsApp, além da implementação da Internet.org (cujo nome foi modificado para Freebasics.com) que visa aglutinar o acesso à internet sob esse domínio (CONVERGÊNCIA DIGITAL, 2015).

Essa configuração oferece acesso à internet pelo smartphone fazendo a conexão em áreas de cobertura da internet móvel, mas principalmente naquelas porções onde não há conexão, através de sinais emitidos por veículo aéreo não tripulado (Vant) ou veículo aéreo remotamente pilotado (Varp). Essa rede só disponibiliza a conexão para o site Facebook e outras aplicações dessa e de outras corporações convergentes ${ }^{35}$ e cobre determinadas regiões com tecnologia wi-fi e rádio com foco na conexão por smartphone. O princípio desse serviço é a execução do chamado zero rating, quando as prestadoras de conexão à internet liberam o acesso "gratuito" a determinada plataforma e os dados transmitidos por essa conexão não são descontados do plano dos usuários.

Além das aplicações mais conhecidas, como ferramenta de busca e e-mail, a corporação Google entrou no mercado de distribuição de notícias em 2016, associando-se a grandes agências como a Agência France Press (AFP) e a Agência Espanhola de Notícias (EFE), por meio da Google Digital News Initiative, que atua em vários países, inclusive no

\footnotetext{
${ }^{35}$ Um exemplo da inserção desse modelo de internet no Brasil é o bairro de Heliópolis, na cidade de São Paulo, que, como teste, recebe hoje os serviços da Internet.org, com o objetivo de atingir seus 200 mil habitantes. Além do Brasil, essa prática já existe em países como Zâmbia, Tanzânia, Quênia, Colômbia, Gana, Guatemala, Filipinas, Peru e Índia, em parceria com as corporações de telecomunicação Samsung, Nokia, Qualcomm, MediaTek, Ericsson e Opera (INTERNET.ORG, 2017).
} 
Brasil. Na infraestrutura da rede suporte, pelo chamado Projeto Tannat, a corporação é proprietária de uma rede própria de fibras óticas, como a que liga Maldonado, no Uruguai, a Santos (SP), aumentando a velocidade de conexão entre os EUA e o Cone Sul.

Simultaneamente, com participação da Google, da Angola Cables, da Antel (Uruguai) e da Algar Telecom (Brasil), outro cabo submarino de fibra óptica, o Projeto Monet, interliga Santos (SP), Fortaleza (CE) e Miami (EUA), com 10 mil quilômetros de extensão, capacidade de comunicação de 60 terabytes e investimento total de cerca de US\$ 300 milhões, confirmando a capacidade da Google de controlar uma importante rede de fibra submarina, que interliga os datacenters distribuídos pelo mundo, sobretudo nos EUA.

Ainda sob domínio da Google, o Projeto Loon provê acesso à internet em regiões sem infraestrutura de rede por meio de 300 balões num anel de internet no hemisfério sul, implantados em 2016 para atender a Indonésia e o Sri Lanka, em parceria com as operadoras Telkomsel, Axiata e Indosat. A conexão é de 10 megabits por segundo, realizada por balões de superpressão a $20 \mathrm{~km}$ de altura e que têm transmissores e receptores de dados, GPS, softwares e painéis solares de energia que duram 187 dias. Para lançar esses balões, são necessários 15 minutos e apenas três pessoas, caracterizando a funcionalidade dessa estrutura e a possibilidade de atender regiões e pontos sem infraestrutura e que não sejam contíguas, também pelo princípio do zero rating.

A posse e o controle da rede serviço e da rede suporte pela Google e pela Facebook rompem a neutralidade da rede, princípio pelo qual o agente que controla a infraestrutura por onde trafegam os dados não pode dar prioridade a determinado serviço, conteúdo ou usuário em detrimento de outros. Como a maioria dos brasileiros usa planos de internet pré-pagos, com uma franquia de dados muito baixa e valor alto, esse acordo entre operadoras e Google e Facebook atrai usuários, mas incentiva o acesso a poucas aplicações e, além de violar o princípio da neutralidade da rede, quebra suas potenciais pluralidade e diversidade, subordinando-a ao poder econômico e à vigilância de poucas plataformas.

Esses usos são intermediados, por exemplo, por aplicativos de relacionamento ou de localização por GPS, que repercutem imediatamente na relação dos indivíduos com o espaço. Essa rede capilarizada promove a ubiquidade das corporações e do Estado, aumentando sua capacidade de influência no território, com as novas possibilidades de fluidez, a complexidade das conexões e o alargamento dos contextos, que, através da internet, permitem um 
intercâmbio de informações cada vez mais eficaz entre áreas mais vastas, fundamentando "a divisão do trabalho que reparte e a cooperação que unifica” (SANTOS, 1996, p. 278).

As técnicas atuais das redes telemáticas concorrem para a conexão entre momentos e lugares, e "a instantaneidade da técnica é um instrumento de convergência dos momentos por suas características, capaz de criar condições sociais inéditas e de estruturar territórios" (DIAS, 1995a, p. 81). Logo, a potência dessa rede se define por sua capacidade de gerar fluxos, pois, quanto mais numerosa, densa e extensa ela é, mais capacidade tem de comandar as práticas espaciais e suas dinâmicas.

As corporações Facebook e Google têm uma logística sofisticada para que seus servidores funcionem com eficiência, por meio de fazendas de servidores, ${ }^{36} \mathrm{com}$ tecnologia especializada para trocar placas queimadas (que esquentam com o uso) por meio de drones, por exemplo. O Facebook tem datacenters com servidores em lugares de clima frio para que se possa resfriá-los melhor, e muitos deles ficam perto do círculo ártico, numa obra de engenharia pensada para otimizar e economizar energia. Um exemplo é o datacenter no norte da Suécia, na cidade de Luleå, que recebe sete petabytes ( $10^{15}$ bytes) de imagens por mês, e a estrutura do prédio ainda conta com 14 geradores de reserva. Essa é, então, uma transformação dos atributos naturais de um território em elementos de competição espacial ou, em outros termos, de apropriação corporativa do território.

As infraestruturas construídas para aumentar a rede suporte sem fio e capilarizar a rede serviço torna o objeto técnico smartphone imprescindível para a conexão à internet nas porções territoriais com menor densidade de infraestruturas telemáticas por cabeamento. Por meio de várias aplicações do smartphone, essas redes devem obedecer aos princípios materiais dos sistemas técnicos cujo funcionamento demanda fluidez e nenhuma resistência. E, quanto mais fragmentado e hierarquizado for o espaço, mais precisará de redes, pois é por meio delas que, cada vez mais, se garantem a continuidade na descontinuidade, a unidade na fragmentação (LENCIONI, 2010).

\footnotetext{
${ }^{36}$ Servidores são computadores com um sistema centralizado que provê serviços a uma rede de computadores.
} 


\subsection{O papel do smartphone como coletor de informações: tratamento das informações dos usuários e economia da informação}

Diante do papel das corporações na conformação de oligopólios na implantação de redes suporte e na prestação de serviços de milhões de sites e aplicativos disponíveis para o smartphone, há uma prática na atual fase da globalização que estimula as pessoas a participarem das maiores redes ou daquelas que oferecem mais opções do interesse dos usuários (ANDERSON, 2006): há nas redes digitais uma tendência à concentração de tráfego em alguns nós com milhares de aplicativos, plataformas e sites disputando a atenção dos usuários de smartphone. No Brasil, os 15 sites mais acessados são das maiores corporações de comunicação (Quadro 7).

Quadro 7 - Ranking dos sites mais acessados no Brasil em outubro de 2018

\begin{tabular}{cl}
\hline Posição & \multicolumn{1}{c}{ Site } \\
\hline 1 & google.com.br \\
\hline 2 & google.com \\
\hline 3 & youtube.com \\
\hline 4 & facebook.com \\
\hline 5 & globo.com \\
\hline 6 & uol.com.br \\
\hline 7 & otvfoco.com \\
\hline 8 & live.com \\
\hline 9 & mercadolivre.com \\
\hline 10 & yahoo.com \\
\hline 11 & instagram.com \\
\hline 12 & blogspot.com \\
\hline 13 & wikipedia.com \\
\hline 14 & whatsapp.com \\
\hline 15 & netflix.com \\
\hline
\end{tabular}

Fonte: Alexa Amazon Company (2018).

As atenções se concentram nos grandes sites já nos mecanismos de busca, nas redes sociais e no repositório de vídeos, e os três primeiros do ranking (Google, Youtube e Facebook) lideram os acessos no mundo todo e têm seu conteúdo majoritariamente produzido pelos próprios usuários. 
Quadro 8 - Ranking dos sites mais acessados no mundo em outubro de 2018

\begin{tabular}{cl}
\hline Posição & \multicolumn{1}{c}{ Site } \\
\hline 1 & google.com \\
\hline 2 & youtube.com \\
\hline 3 & facebook.com \\
\hline 4 & baidu.com (site de buscas chinês) \\
\hline 5 & wikipedia.com \\
\hline 6 & qq.com (portal de internet chinês) \\
\hline 7 & yahoo.com \\
\hline 8 & taobao.com (site de compras chinês) \\
\hline 9 & tmall.com (site de compras chinês) \\
\hline 10 & amazon.com \\
\hline 11 & google.co.in (site de buscas indiano) \\
\hline 12 & twitter.com \\
\hline 13 & sohu.com (portal de notícias japonês) \\
\hline 14 & instagram.com \\
\hline
\end{tabular}

Fonte: Alexa Amazon Company (2018).

As corporações Google e Facebook, que concentram os acessos da internet, absorvem empreendimentos criativos na rede para ampliar suas opções de entretenimento e serviços: por exemplo, a Google comprou o Youtube e o DoubleClick, e a Facebook, o Instagram e o WhatsApp.

Quando a internet se popularizou, no início dos anos 2000, a Google dependia da web aberta e universal para fornecer seu serviço de busca monopolizado. Com o advento dos aplicativos nos smartphones, popularizados a partir de 2010, a empresa desenvolveu o Android, um sistema operacional para smartphones que permitia fazer downloads diretamente nos aplicativos, sem precisar acessar a web. Outro fato importante para o controle de dados pessoais foi a compra da plataforma WhatsApp em 2014 pela Facebook. Aumentou sua capacidade de conhecer, obter e comercializar dados dos usuários que acessam essa plataforma específica, e seu uso se popularizou e capilarizou principalmente no território brasileiro, afetando muitas práticas banais do cotidiano, seja na interatividade, na comunicação ou na mobilidade. Assim, essas corporações multiplicaram seus rendimentos comprando e vendendo dados pessoais.

A rede web nasceu com uma "arquitetura aberta, distribuída, com protocolos não patenteados, sem um dono ou proprietário, seguiu a lógica da liberdade e não da permissão, assegurando que um conteúdo pode ser criado e imediatamente colocado na rede para acesso amplo" (SILVEIRA, S., 2017a, p. 54). Após a privatização do setor das telecomunicações em 
praticamente todo o globo, entre os anos 1980 e 1990, as corporações estreitaram seus laços, conformando um oligopólio de posse e controle da infraestrutura indispensável à comunicação digital, pois nas suas redes de fibra ótica transita toda a comunicação digital do planeta. Nesses termos, as corporações rompem o princípio da neutralidade da rede comercializando a quantidade e a velocidade de dados transmitidos por meio de suas infraestruturas, podendo também filtrar e cobrar pelo conteúdo.

Para filtrar dados e gerir a rede, aplicam-se técnicas de análise do fluxo de informações que passa pelas fibras óticas e pelos cabos, a fim de priorizar, bloquear, retardar ou diminuir a velocidade de determinados pacotes digitais (RIFKIN, 2001). Além dessa interferência, a obtenção de dados por essas corporações captura informações específicas e cruza dados sobre lugares, períodos e atividades realizadas pelos indivíduos (SHAPIRO, 2003).

Os dispositivos podem ser vigiados e seus arquivos analisados com rastreamento das "pegadas digitais" pelo envio de cookies e pixels, que são pequenos arquivos que identificam os computadores na rede. Ao mesmo tempo, se processam e analisam os dados captados e se os cruzam com outras bases de dados com técnicas preditivas que se expandem com a big data.

Os smartphones geram automaticamente dados para controle de qualquer aplicação, e são muitos num único dia de conexão à internet. Como são agrupados durante um intervalo de tempo, isso permite compor um padrão de comportamento, de práticas e de informações pessoais. Ao lado da ampliação da eficiência em armazenar e tratar os dados, a banalização do uso do smartphone expande a capacidade de obter dados pessoais de um imenso número de usuários por todo o território.

Esses dados pessoais consistem em informações fornecidas para abrir uma conta bancária como nome, endereço, telefone, informações sobre o própria conta e o cartão e outras que o usuário divulga fazendo comentários em redes sociais, dados que um usuário envia a outro e dados comportamentais sobre suas ações ao acessar um site (SCHNEIER, 2009).

Os dados fornecidos por smartphone podem ser associados para se conhecer a identidade de quem o utiliza, por exemplo, cruzando dados de GPS e endereços IP e outros 
bancos de dados. Assim, o mercado negocia as tendências de comportamento dos indivíduos, principalmente sobre o consumo (NARAYANAN; SHMATIKOV, 2010).

A cadeia de humanos e não humanos que constitui o mercado de dados pessoais envolve grandes corporações e empresas, plataformas, usuários, agências de marketing e publicidade, servidores e datacenters, programas de rastreamento e de tratamento de banco de dados. O tratamento das informações começa com a obtenção e a estocagem de dados, para depois processá-los e minerá-los. ${ }^{37} \mathrm{~A}$ etapa seguinte é sua análise e a organização de amostras para modular ou articular esses dados (NARAYANAN; SHMATIKOV, 2010).

A interatividade dos usuários nas redes é dada, por exemplo, por seus acessos e pelo tempo de conexão, que são armazenados e registrados em grandes bases de dados de empresas e corporações. A modulação ocorre por meio da análise do processamento de informações com filtros e algoritmos de controle de visualização. A partir daí, se qualificam grupos de consumidores, por exemplo.

Os dados comercializados pela Google e pelo Facebook derivam do tratamento de informações obtidas em ações de usuários que acessam suas redes e, assim, são modulados os públicos a quem se oferecem produtos, notícias etc. Essas corporações não cobram por seus serviços porque sua renda provém da venda de dados e de publicidade direcionada, já que acessam os dados pessoais de bilhões de usuários, que podem ser processados e agrupados e ser alvos de vários objetivos, sobretudo comerciais (SILVEIRA, S., 2017a).

\subsection{Agentes que modulam dados: robôs e algoritmos}

A partir da obtenção, do tratamento e da comercialização de dados, surgem novas técnicas para utilizar a grande massa de dados produzida permanentemente para vários fins, como a influência em práticas e interações espaciais (CORRÊA, R., 1997).

Os chamados "robôs virtuais" conformam redes que podem atingir grandes proporções, principalmente em plataformas de redes sociais, com capacidade para chegar a

\footnotetext{
${ }^{37}$ Minerar é um jargão na área de programação e processamentos de dados que significa analisar, processar para encontrar padrões e correlações em grandes conjuntos de dados para prever resultados.
} 
milhões. Por meio de comandos informacionais, numerosos "exércitos de robôs" 38 podem marcar, curtir e comentar postagens em redes sociais que tenham determinadas palavraschave. Quando os algoritmos de redes sociais registram uma atividade intensa sobre determinado tema, ele é considerado popular e, então, é exibido para mais usuários, o que é utilizado para a manipulação de assuntos populares e para fins políticos, influenciando comportamentos.

Os robôs também são capazes de influenciar o resultado de eleições, por exemplo, difundindo notícias falsas (as chamadas fake news), selecionando críticas e apoiando certos pontos de vista. Logo, o acesso à internet passa por uma estrutura privada que obtém os dados dos usuários, conhece suas singularidades e pode influenciar seu comportamento. Assim, os algoritmos são uma ferramenta de sequências lógicas com instruções para realizar tarefas desenvolvida por humanos com todas as suas singularidades e ideologias (SILVEIRA, S., 2017b), o que conforma uma cadeia de humanos e não humanos e cria uma camada lógica que organiza os usuários em classes de consumidores e em perfis de comportamento para realizar vários tipos de negócio sob a intencionalidades de agentes humanos.

Os algoritmos medeiam experiências, atenção, condutas e padrões cognitivos, lúdicos, afetivos e políticos (SILVEIRA, S., 2017a), e o uso do smartphone produz rastros e memórias que agora têm valor comercial. Os rastros digitais são persistentes e recuperáveis, alimentando corporações como Facebook e Google.

Neste período, há uma fonte inesgotável de conhecimento sobre indivíduos e populações pela obtenção de informações e pela produção de padrões de comportamento, consumando o capitalismo de vigilância (SILVEIRA, S., 2017b). A observação regular de um grupo de indivíduos provê vigilância, controle, intervenção e condução de comportamentos.

Um exemplo é a empresa Serasa Experian, cuja plataforma chamada Mosaic organiza dados da população por meio de algoritmos classificando-a em seguimentos de A a K, da elite a moradores de áreas pobres, precárias ou rurais, servindo corporações, bancos, empresas e Estado para compras ou acesso a crédito e empresas de recursos humanos para acesso ao

\footnotetext{
${ }^{38}$ Robôs são programas que intervêm automaticamente em redes sociais. Criam contas falsas simulando pessoas reais que são operadas por máquinas com o objetivo de disseminar um assunto. Existem softwares e programas que criam contas e alimentam plataformas com os conteúdos que elas devem disseminar. Os conteúdos que os robôs postam nas redes são muito parecidos e com um curto intervalo de publicação. É fácil criá-los e mantê-los, pois eles não necessariamente interagem com pessoas reais, mas difundem determinado assunto pelas redes, por meio do enorme número de contas falsas que existem atualmente.
} 
perfil econômico e psicológico das pessoas (SERASA EXPERIAN, 2018). Esses dados são colhidos em plataformas como Facebook, Google, sites e aplicativos de bancos, e-mails, sites de compras etc. para classificar, segundo um critério algorítmico, aqueles que podem ou não ter acesso a determinados serviços, trabalhos e até direitos fundamentais (SILVEIRA, S., 2017a). Logo, essa camada lógica afeta diretamente a vida das pessoas e o território.

Os algoritmos são técnicas a que subjazem intenções, desenvolvidos em empresas e corporações e também comercializados com Estados, com a justificativa de que são produtos eficazes e neutros, adequando-se e submetendo aos interesses de quem os utiliza, pois "a imaterialidade e a invisibilidade dos algoritmos reforçam a prática discursiva de uma tecnicidade neutra e de uma racionalidade naturalizada que implicam o tratamento não político e não crítico dos códigos no setor público” (SILVEIRA, S., 2017a, p. 108).

Essa ferramenta automatiza um processo de análise de dados que seria impossível executar manualmente, e seu resultado é utilizado para muitas operações, sobretudo para a tomada de decisões (BAROCAS; HOOD; ZIEWITZ, 2013, p. 5).

Os resultados gerados não podem ser previstos com antecedência, implicando responsabilidade da constituição dessa ferramenta e de seus projetistas nas decisões que forem tomadas, pois a intenção humana é um elemento fundamental do funcionamento do algoritmo.

A lógica dos algoritmos é simplista e reducionista (INTRONA, 2013), pois são editados por programadores de forma a que os problemas se adaptem às soluções do próprio algoritmo, que "executam performaticamente ações sobre uma realidade que vai produzindo diferentes entidades à maneira que agem" (SILVEIRA, S., 2017b, p. 88).

Essas técnicas comunicam e controlam concomitantemente e seguem as intenções implícitas nas tecnologias informacionais hegemônicas:

Quando dou uma ordem a uma máquina, a situação não difere essencialmente da que surge quando dou uma ordem a uma pessoa. Por outras palavras, tanto quanto alcança minha consciência, estou ciente da ordem emitida e do sinal de aquiescência recebido de volta. Para mim, pessoalmente, o fato de o sinal, em seus estágios intermediários, ter passado por uma máquina em vez de por uma pessoa, é irrelevante, e em nenhum caso altera significativamente minha relação com o sinal (NORBERT, 1968, p. 16). 
Por meio desse sistema de controle de informações global, é possível manter e reproduzir relações sociais fundamentadas nas redes. A justificativa para acessar os dados dos usuários é o alegado compromisso das redes com a transparência. Por outro lado, não se sabe o que é captado e gerado com esse material coletado pelas corporações e pelo Estado.

Assim, as tecnologias de modulação constroem uma rede de humanos e não humanos implicando a "construção de situações sociais, interações específicas e agindo sobre a atenção dos usuários por serem quase sempre baseadas em nossa subjetividade revelada e em nosso potencial afetivo" (SILVEIRA, S., 2017a, p. 188). 


\title{
CAPÍTULO 3 \\ CAPILARIZAÇÃo DA INFORMAÇÃo PELO SMARTPHONE NO TERRITÓRIO BRASILEIRO E A DINÂMICA NA REDE URBANA ATUAL
}

\begin{abstract}
Objetos que existem simplesmente como objetos; apartados de uma vida coletiva, são desconhecidos, são sepultados. Os artefatos técnicos acham-se tão distanciados do status da eficiência quanto os fatos científicos do nobre pedestal da objetividade. Os artefatos reais são sempre parte de instituições, hesitantes em sua condição mista de mediadores, a mobilizar terras e povos remotos, prontos a transformar-se em pessoas ou coisas, sem saber se são compostos de um ou de muitos, de uma caixa preta equivalente a uma unidade ou um labirinto que oculta multiplicidades. Os boeings 747 não voam, voam as linhas aéreas.
\end{abstract}

Bruno Latour, 2001

A estruturação da rede suporte e da rede serviço da internet que viabilizam a capilarização da informação por meio do smartphone têm uma correlação direta com a caracterização da rede urbana nacional. No processo de urbanização, a rede urbana é o meio pelo qual se realizam efetivamente a produção, a circulação e o consumo. Funcionalmente articulados entre si e constituindo um elemento essencial da rede urbana, os centros urbanos têm os nós que concentram densidade populacional, densidade de objetos técnicos e serviços urbanos que se conectam com os diferentes fluxos entre esses centros (CORREAA, R., 2001).

Em determinadas áreas onde se concentram muitas redes, sobretudo de informação e comunicação, é que se produz o meio técnico-científico-informacional, no momento em que os sistemas técnicos são implantados e utilizados, resultando em mudanças no território que, sob novos fundamentos e novos conteúdos de informação, concebem a expansão do sistema de forma reticular, favorecendo o alargamento dos contextos (SANTOS, 2006), dada a conexão entre lugares próximos e isolados por meio do aperfeiçoamento de técnicas para capilarizar da informação.

A rede urbana é um produto social e histórico onde, pelas relações no espaço, se estruturam as redes da sociedade. As diferenças espaciais decorrentes da constituição dos processos sociais e das diferentes temporalidades condicionam a existência de vários tipos de rede urbana e várias densidades de redes técnicas implementadas de forma desigual no território brasileiro. 


\subsection{Características da rede urbana brasileira e distribuição das redes}

O sistema de economia de mercado promoveu a atual divisão territorial do trabalho, sob a qual as cidades ficaram muito integradas. Na rede urbana, encontram-se fixos que garantem a realização de transações comerciais e promovem interações diferenciando-as e resultando em especializações produtivas (CORRÊA, R., 1997). Assim, a rede urbana é um conjunto de cidades que faz uma intermediação diferenciada de decisões originadas dentro ou fora do território nacional; em geral, essas cidades operam como nós de uma ampla rede com sedes em outros países e, por isso, os sistemas informacionais mediadores são imprescindíveis à divisão internacional do trabalho contemporânea.

Os agentes estruturados em rede e que têm o poder de definir e impor funções são as corporações, frequentemente em parceria com Estados e governos, que possibilitam a integração de pontos selecionados de territórios com papel destacado na economia global. Assim, determinadas cidades se transformam em centros de gestão capazes de comandar as redes urbanas em diferentes países.

A rede urbana brasileira é marcada por uma "complexidade genética, com diversos padrões espaciais, crescente complexidade funcional do seu centros e diversos tipos e intensidade de integração interna e externa" (CORRÊA, R., 2001 p. 95) e, portanto, é composta de diversas acumulações desiguais de tempo (SANTOS, 2006), em que convivem, no mesmo espaço da cidade, fixos que surgiram no início da colonização e outros construídos no começo do século XXI, sob a ação de diferentes processos que constituem centros urbanos em tempos desiguais.

Logo, a rede urbana nacional não tem um único padrão espacial, pois o território apresenta altas densidades demográficas e de redes técnicas em algumas porções da região Sudeste e nas capitais nordestinas e, ao mesmo tempo, também há baixas densidades nas regiões Norte, Centro-Oeste e Nordeste.

O padrão dendrítico da ocupação do território brasileiro foi definido primeiramente pela constituição de cidades no litoral, como pontos de defesa e meios de entrada para ocupar e dominar o interior. Com essa estratégia, são estabelecidas cidades subordinadas aos centros urbanos próximos ou no litoral. 
Já as redes urbanas industriais - como, por exemplo, na região Sudeste, na Região Metropolitana de São Paulo ou no Vale do Paraíba - são os eixos que efetivam a integração funcional e configuram um padrão espacial de "corredores urbanizados" (CORRÊA, R., 2001).

Até meados do século XX, a densidade de funções dos centros urbanos se diferenciava pelos tipos de serviços e bens que distribuía, comercializava ou beneficiava; a divisão territorial do trabalho se configurava pelas funções de cada um, segundo o modelo hierárquico da teoria dos lugares centrais, de Walter Christaller (CHRISTALLER, 1966). Essa hierarquia era definida em razão do tamanho, da importância, da dimensão dos fluxos e das funções de cada cidade, relativos à quantidade e à diversidade de bens e serviços que forneciam a sua área de influência, para tornar mais eficiente a economia do Estado.

A partir das transformações tecnológicas que se refletiram em todas as escalas espaciais pela expansão e capilarização da internet e da banalização do uso dos smartphones no começo do século XXI, a fluidez no território e a segmentação social tornaram-se mais complexas e demandaram, além das inovações no campo, a complexificação funcional dos centros urbanos brasileiros (CORRÊA, R., 2001). Assim, o modelo tradicional de hierarquia urbana já não consegue explicar a rede de cidades brasileiras, pois só a posição de cada centro na atual conjuntura não basta para caracterizar e desvendar sua importância nessa rede.

A divisão territorial do trabalho nos centros urbanos se expande, e a complexidade funcional de cada centro resulta na sua conexão concomitante com várias redes regionais, nacionais e internacionais.

A variedade de agentes e heranças e suas relações são intensificadas por ações que visam tornar mais eficiente e capilarizado o novo paradigma de conexão entre os lugares e regiões não contíguas por meio da implantação de redes pelo Estado e pelas corporações. Nesse momento, essa integração começa a envolver relações interescalares, em que diversos pontos do território se conectam a diversas redes que têm diferentes papéis e obedecem a ordens que emanam de pontos distantes.

A partir da organização em rede, os fluxos, que em outros períodos eram exclusivamente regionais, têm agora um alcance maior, por se conectar com outras metrópoles nacionais e internacionais, capitais regionais ou nacionais e pequenos centros isolados. 
A intensidade e velocidade com que se integrou a rede urbana no Brasil se deveram a ações que transformaram a estrutura econômica e as vias de circulação de bens e informações pela implementação de redes de telecomunicação em pontos selecionados do território, principalmente aqueles que tinham já tradicionalmente uma densidade técnica importante. Assim, o processo de capilarização da informação e comunicação por meio dessas redes incorporou novas demandas e um novo fluxo, acompanhando o desenho desigual das densidades técnicas no território.

Esse processo permite que as interações espaciais se manifestem no espaço envolvendo fixos e fluxos (SANTOS, 2006). As estruturas fixadas em cada ponto do território possibilitam ações que modificam o próprio lugar segundo os fluxos que elas controlam.

Para Roberto Lobato Corrêa (1997), as interações espaciais são componentes do espaço geográfico resultantes dos deslocamentos multidirecionais de bens, pessoas, capitais e informações com diversas densidades de fluxos e velocidades, de acordo com os objetivos e os meios para estabelecê-los.

Logo, as interações espaciais intensificam e transformam processos de acumulação de capital, pois se sucedem no contexto da divisão social e territorial do trabalho, manifestando as desigualdades de densidades de fluxos, direções e padrões (CORRÊA, R., 1997). As interações espaciais propiciadas pela capilarização da informação por meio do smartphone também repercutem em transformações espaciais, considerando sua distribuição desigual no espaço.

No contexto das metrópoles brasileiras, marcadas pela concentração demográfica e pelo setor de serviços, a população usa muito o smartphone, intensificando a integração a movimentos e redes de trocas e distribuindo serviços estratégicos para outros pontos do território.

Para Reis (1996), o movimento de metropolização se apoia numa rede de transportes e telecomunicações por meio das quais se desenvolve um processo simultâneo de descentralização e centralização. Esse movimento determina as condições de crescimento que acompanha a expansão das redes, sobretudo as de comunicação do período atual.

A rede de infraestruturas que fornece sinal de internet exige a instalação de objetos na cidade a partir de princípios técnicos específicos, com torres de transmissão, como as ERB, 
fios de cobre e de fibra ótica, tanto em postes como em dutos subterrâneos, estabelecendo conexão com vários níveis de rede.

A oferta e a qualidade dos serviços e da instalação dessas infraestruturas são espacialmente desiguais, pois as empresas buscam o retorno dos investimentos onde há demanda. Há uma relação direta com a implementação das infraestruturas técnicas e o desenho da cidade: muitas delas servem como dinamizadores para a ocupação de determinadas áreas, por sua instalação planejada e pela relação entre especulação imobiliária e poderes públicos, pois permitem a conexão entre vários agentes, e sua expansão generalizada leva à banalização do uso e acesso aos meios da cidade.

A integração entre os pontos numa rede urbana é tão mais relevante quanto mais dispersas estão as condições de produção e o consumo de mercadorias no espaço, e, portanto, as redes expressam a escala das ações sociais (DIAS, 2005). No processo de organização e implementação das redes, o espaço geográfico é constituído por objetos técnicos dispostos em sistemas indissociáveis dos sistemas de ações que as animam e lhes dão significados (SANTOS, 2012).

As redes são um conjunto de localizações geográficas interconectadas por certo número de ligações (CORRÊA, R., 2001) e, no arranjo e na ampliação das trocas sob o sistema capitalista, são imprescindíveis para que a divisão territorial do trabalho tenha a atual escala global e funcione segundo as variadas redes técnicas imbricadas que se manifestam de forma complexa nas redes urbanas, com seus centros especializados e hierarquizados por onde fluem diversos elementos, materiais e não materiais. Assim, as cidades que abrigam sedes ou filiais de corporações transnacionais "multifuncionais" e "multilocalizadas" concretizam os numerosos e complexos nós das redes que reforçam uma organização desigual do espaço, ao mesmo tempo fragmentada e globalizada.

O arranjo espacial das interações se realiza por pontos e linhas e, no contexto das redes que constituem e viabilizam o uso dos smartphones, dão-se as interações espaciais não contíguas. Consideramos que as interações espaciais são os meios nos quais "as formas espaciais articulam-se entre si, realizando as funções que os processos espaciais lhes atribuíram. Processos, formas e interações espaciais constituem uma unidade, fundamentais para compreender a espacialidade humana" (CORRÊA, R., 2016, p. 122). Portanto, as interações espaciais são também reflexo e condição dos processos sociais. 
As formas dessa rede que enseja as interações espaciais realizam os processos e cumprem ordens que são determinadas tecnicamente, para cada uma de suas funções, através da cadeia complexa que as compõe, formada por elementos humanos e não humanos. A história da reprodução das sociedades é constituída de interações espaciais, e a cada período corresponde um tipo de interação; a partir da primeira revolução industrial e da consolidação do capitalismo, elas se tornaram mais complexas, intensas, superpostas e interligadas.

Entendido como acumulação desigual de tempos (SANTOS, 1996), o espaço acumula também interações espaciais que variam segundo o período e o lugar onde ocorrem. Logo, o período atual "é um capítulo em uma longa história das interações espaciais, quer dizer, da espacialidade humana, envolvendo o permanente esforço de superação do espaço pelo tempo" (CORRÊA, R., 2016, p. 125).

As categorias distância, intensidade e direção são imprescindíveis para caracterizar as interações espaciais e interpretar a espacialidade humana. Ademais, a duração, a velocidade, a frequência, o ritmo e o período em que acontecem os eventos são importantes para observar os fenômenos sob a ótica do tempo:

\begin{abstract}
Interações longas ou curtas, lentas, rápidas ou instantâneas, diárias, semanais ou mensais, separadas por um maior ou menor lapso de tempo e ocorrendo em períodos próprios, como na safra, nas férias ou no tempo sagrado, revelam possíveis variações que aparecem de modo combinado. O mapa do mundo é recoberto por inúmeros fluxos, distintos qualitativa e quantitativamente, revelando a espacialidade humana desigual, reforçando a desigualdade das formas espaciais (CORRÊA, R., 2016, p. 129).
\end{abstract}

A capilarização da informação por meio do smartphone proporciona um tipo de interação espacial caracterizada por sua inserção numa rede de múltiplos circuitos, com uma distribuição de pontos ligados a atividades econômicas, políticas e sociais que se dão por meio de vias e numerosos pontos e nós.

Os pontos que conformam essa rede são os agentes e suas relações: os agentes que têm mais de uma relação um são chamadas de nós e conformam uma rede quando possibilitam e são demandados por outro ponto ou outro nó. O pressuposto dessas redes é sua velocidade e sua flexibilidade ao conectar e desconectar pontos e ações remotas, o que provoca uma instabilidade potencial de cada ponto ou nó, e parte de sua força está na habilidade de fazer e desfazer rapidamente as conexões (DUARTE; FREY, 2008). 
Essa rede funcional tem estruturas que desenham o território e perfazem conexões manipuladas por agentes que podem produzir relações e fazer circularem informações. Essa é uma rede de ideias ou de modos de pensar e agir conectando pontos remotos. As redes sociais utilizadas por meio dos smartphones se dão como um sistema interescalar que emite ordens para todos os pontos conectados. Presentes em muitos âmbitos da vida de cada indivíduo, esses fluxos informacionais constituem redes de ações que não só disseminam informação, mas formam redes que desencadeiam ações muitas vezes momentâneas e nem sempre mapeáveis.

\subsection{Arranjos populacionais da rede urbana brasileira}

O território brasileiro tem 294 arranjos populacionais, formados por 953 municípios e que representam 55,7\% dos habitantes, isto é, 106.246.994 pessoas (IBGE, 2016a). Os chamados arranjos populacionais são compostos por mais de dois municípios, sendo $90 \%$ deles formados por até cinco. Essa configuração sugere que o processo de aglomeração se intensifica em centros de menor porte populacional com o passar dos anos e que se distribuem em grandes regiões (Gráfico 2).

Gráfico 2 - Arranjos populacionais de 100 mil até 750 mil habitantes, Brasil, 2016

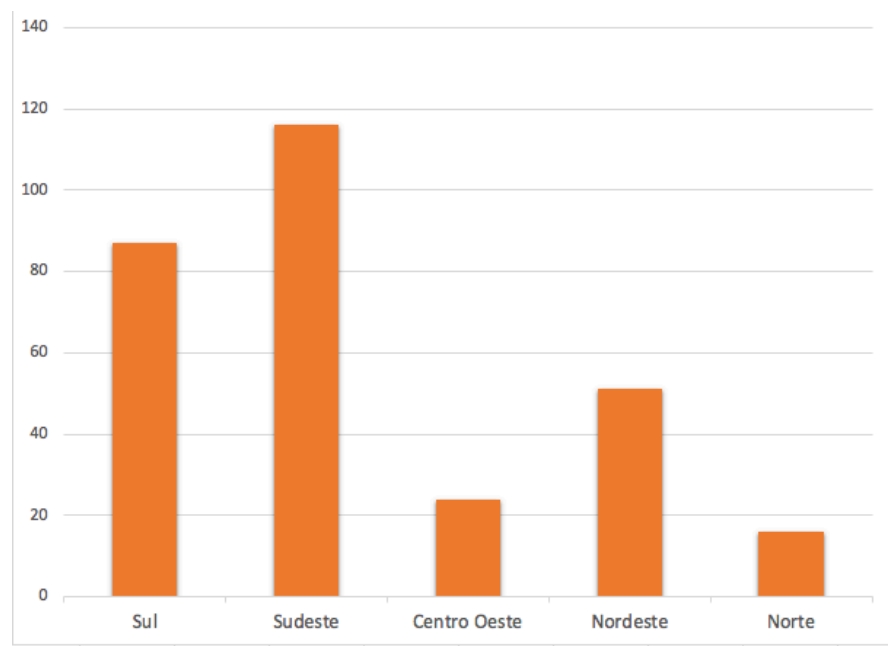

Fonte: IBGE (2016a).

Elaboração: Mait Bertollo.

O Gráfico 2 sintetiza e compara quantitativamente os arranjos populacionais, distribuídos entre as regiões Sudeste, com 116 unidades, Sul, com 87, Nordeste, com 51, Centro-Oeste, com 24, e Norte, com 16 (IBGE, 2016a). 
As chamadas médias concentrações urbanas e os municípios isolados têm uma população entre 100 mil e 750 mil habitantes; existem ao todo 80 municípios isolados e 79 arranjos populacionais.

As maiores densidades urbanas no Brasil são representadas por 26 grandes concentrações, formadas por arranjos populacionais com mais de 750 mil habitantes. Dois desses municípios são isolados e não perfazem arranjos - Manaus (AM) e Campo Grande (MS) -, ainda que sua população ultrapasse os 750 mil habitantes.

Esses 24 arranjos com mais de 750 mil habitantes estão distribuídos entre as regiões Sudeste, com 8 concentrações, Nordeste, com 9, Centro-Oeste, com 4, Sul, com 3, e Norte, com 2, que podem ser comparadas quantitativamente (Gráfico 3).

Gráfico 3 - Arranjos populacionais com mais de 750 mil habitantes, Brasil, 2016

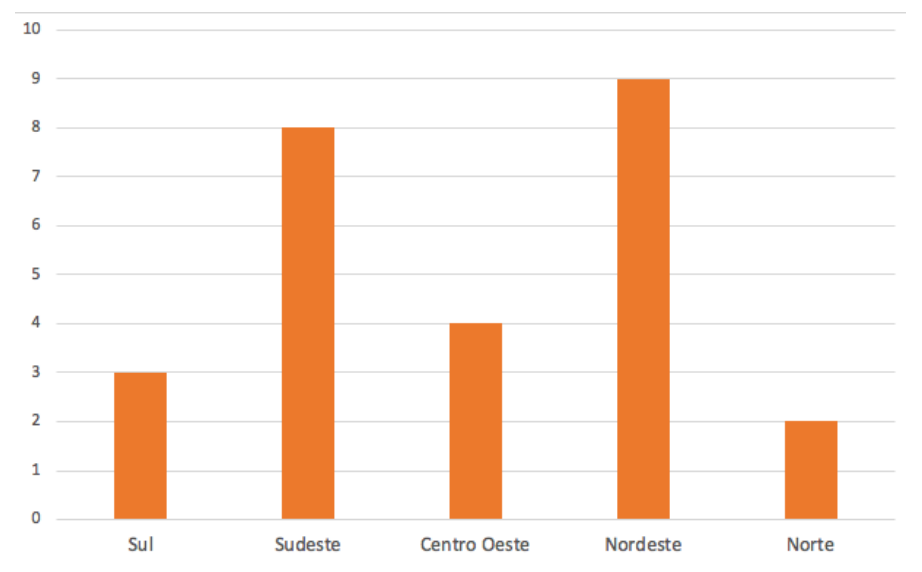

Fonte: IBGE (2016a).

Elaboração: Mait Bertollo.

Em conjunto, esses municípios somam 79,124 milhões de habitantes e reúnem 41,5\% da população do país. Dessas grandes concentrações urbanas, nove são aglomerações de caráter metropolitano, com população superior a 2,5 milhões de habitantes, que englobam São Paulo (SP), Rio de Janeiro (RJ), Belo Horizonte (MG), Recife (PE), Porto Alegre (RS), Salvador (BA), Brasília (DF), Fortaleza (CE) e Curitiba (PR).

Essas cidades têm uma densidade de redes técnicas para acesso à internet e uso massivo de smartphones que amplia a interligação dos centros urbanos e reforça a divisão territorial do trabalho, com uma nova organização de atividades econômicas e sociais sob nova configuração espacial, em que a expansão da rede suporte da internet em centros urbanos aumenta a capacidade de acesso e fornecimento de serviços. 
Justificam essa diversidade os múltiplos processos que concorrem para a formação dos arranjos populacionais: a intensa dinâmica da urbanização e os desmembramentos políticoadministrativos dos municípios. As regiões Sudeste e Sul, onde os dois processos são muito intensos, detêm o maior número de arranjos, o que revela suas influências regionais. $\mathrm{O}$ Nordeste está na terceira posição em número de arranjos, seguido do Centro-Oeste. No Norte, onde os processos de urbanização e desmembramento são menos intensos, verifica-se um número menor de arranjos e uma menor participação da população vivendo em arranjos populacionais. No Nordeste, os arranjos populacionais são claramente próximos ao litoral, ainda que ocorram em menor número também no interior da região, sobretudo vinculados a centros regionais tradicionais como Petrolina (PE), Juazeiro (BA), Juazeiro do Norte (CE) e Campina Grande (PB).

Na região Sudeste, além das metrópoles, os arranjos populacionais acompanham os grandes centros urbanos. Destacam-se, em Minas Gerais, Ipatinga (MG) e Juiz de Fora (MG); no Rio de Janeiro (RJ), o litoral norte, com Campos dos Goytacazes (RJ) e Macaé (RJ), e, no Vale do Paraíba, Volta Redonda (RJ). Em São Paulo, os arranjos seguem também os principais eixos econômicos articulados pelas rodovias Presidente Dutra (São José dos Campos e Taubaté), Anhanguera (Campinas e Ribeirão Preto), Imigrantes (Baixada Santista), BR-456 (Araraquara e São José do Rio Preto) e SP-300 (Bauru).

Na região Sul, destaca-se o litoral norte de Santa Catarina, formado por arranjos próximos uns dos outros e com população de 350 mil a um milhão de habitantes. São relevantes as cidades de Joinville, Blumenau, Itajaí e Florianópolis. Além dessas, formam arranjos populacionais equivalentes as cidades de Criciúma (SC), Pelotas (RS), Caxias do Sul (RS), Maringá (PR), Londrina (PR) e Foz do Iguaçu (PR). Os maiores arranjos estão associados às metrópoles de Porto Alegre (RS) e Curitiba (PR), ambas com população próxima a 3 milhões de habitantes.

Nas regiões Norte e Centro-Oeste, os arranjos estão ligados principalmente a grandes núcleos urbanos como Belém (PA), Goiânia (GO) e Brasília (DF). A metrópole de Manaus é uma exceção, pois fica na confluência dos rios Solimões e Negro; até 2011, antes da construção da Ponte Rio Negro, os deslocamentos entre municípios eram feitos por barco. Outro aspecto é a vasta extensão territorial do município de Manaus, que dificulta a formação de um arranjo populacional. 
A rede urbana brasileira também tem 189 arranjos de até 100 mil habitantes, com baixa concentração populacional, que correspondem a $64 \%$ do total e reúnem 8,36 milhões de habitantes. Muitos deles estão no entorno de capitais como São Paulo (SP), Rio de Janeiro (RJ), Belo Horizonte (BH), Porto Alegre (RS), Salvador (BA) e João Pessoa (PB).

\subsection{Distribuição dos smartphones e usos no território}

No período atual, os sistemas técnicos e suas sucessivas inovações se difundem rapidamente por causa da aceleração entre sua concepção e seu desenvolvimento, concomitante com uma racionalidade imposta por meio da implementação de vários objetos técnicos em rede, imprescindíveis à acumulação capitalista atual, levada a um grande número de lugares (SANTOS, 1996). Esses sistemas são irreversíveis na medida em que se convertem em necessidades, pois podem ser usados de forma banal por todos os estratos da população.

Tais redes têm suas malhas e nós multiplicados e possibilitam a articulação e o domínio de territórios não contíguos (RAFFESTIN, 1985). Assim, o caráter político das redes técnicas pressupõe controle, pois elas:

[...] facilitam a obtenção de legitimidade, a mobilização das forças extralocais, as alianças necessárias para influir em decisões de foros maiores, e é possível adquirir uma fluidez escalar que pode servir inclusive para reforçar o poder local (DORFMAN, 1995, p. 106).

Esses sistemas encadeados medeiam muitas interações espaciais sob as particularidades da formação socioespacial brasileira, cujo território tem dimensão continental e profundas desigualdades regionais como as de infraestrutura. Ao mesmo tempo, a crescente internacionalização do capital e a ascensão das corporações resulta na procura por lugares mais rentáveis e, assim, os projetos locais são condicionados por estratégias globais (SANTOS, 1994). 
A integração em rede não é só um fator de competitividade, mas também de acesso a um direito fundamental: a comunicação. Segundo o Instituto Brasileiro de Geografia e Estatística, com base na Pesquisa Nacional por Amostra de Domicílios (IBGE, 2016b), a quantidade e qualidade da conexão da internet por meio do uso do smartphone, em comparação com outros aparatos de conexão, por renda, por unidade da federação e por região, tem um uso crescente e distribuído territorialmente (Mapa 11).

Mapa 11 - Número de usuários de smartphone no Brasil, por unidade da federação e por região metropolitana, 2016

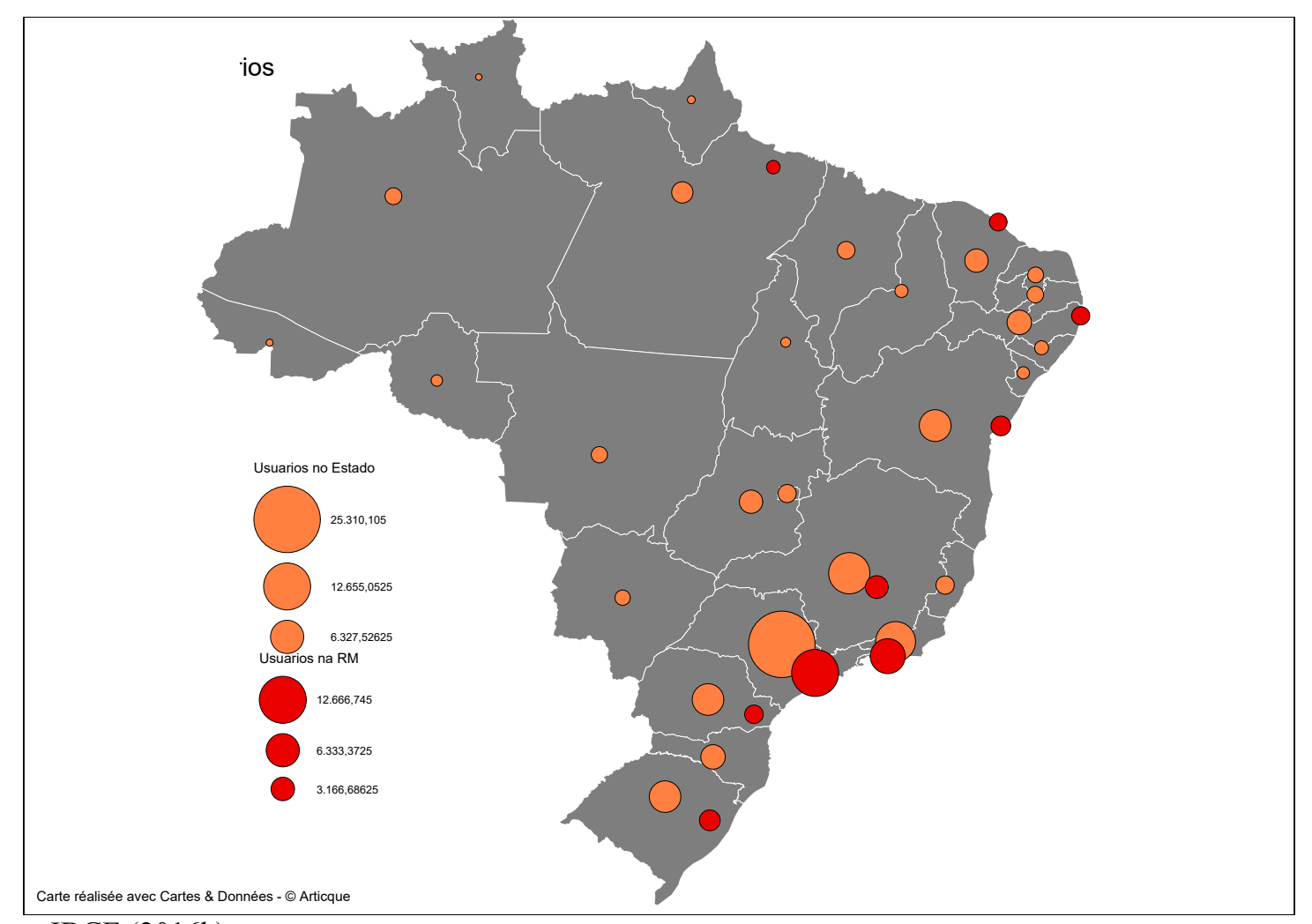

Fonte: IBGE (2016b).

Organização: Mait Bertollo

Elaboração: Hervé E. R. Thery.

No Mapa 11, vemos o número de usuários de smartphone por unidade da federação e por região metropolitana. A concentração é maior na região Sudeste, principalmente no estado de São Paulo e na região metropolitana da capital. Na região Norte e em alguns estados do Nordeste, observamos uma menor densidade de infraestrutura de conexão e menos acesso à rede. Considera-se o movimento de informacionalização do espaço (SANTOS, 1994) condição indispensável ao exercício do poder econômico e político, entretanto, a distribuição dos usuários de smartphone revela que as novas variáveis não se distribuem uniformemente na escala nacional. 
Mapa 12 - Acesso à internet e uso de dispositivos: computadores e smartphones no Brasil, por unidade da federação, 2016

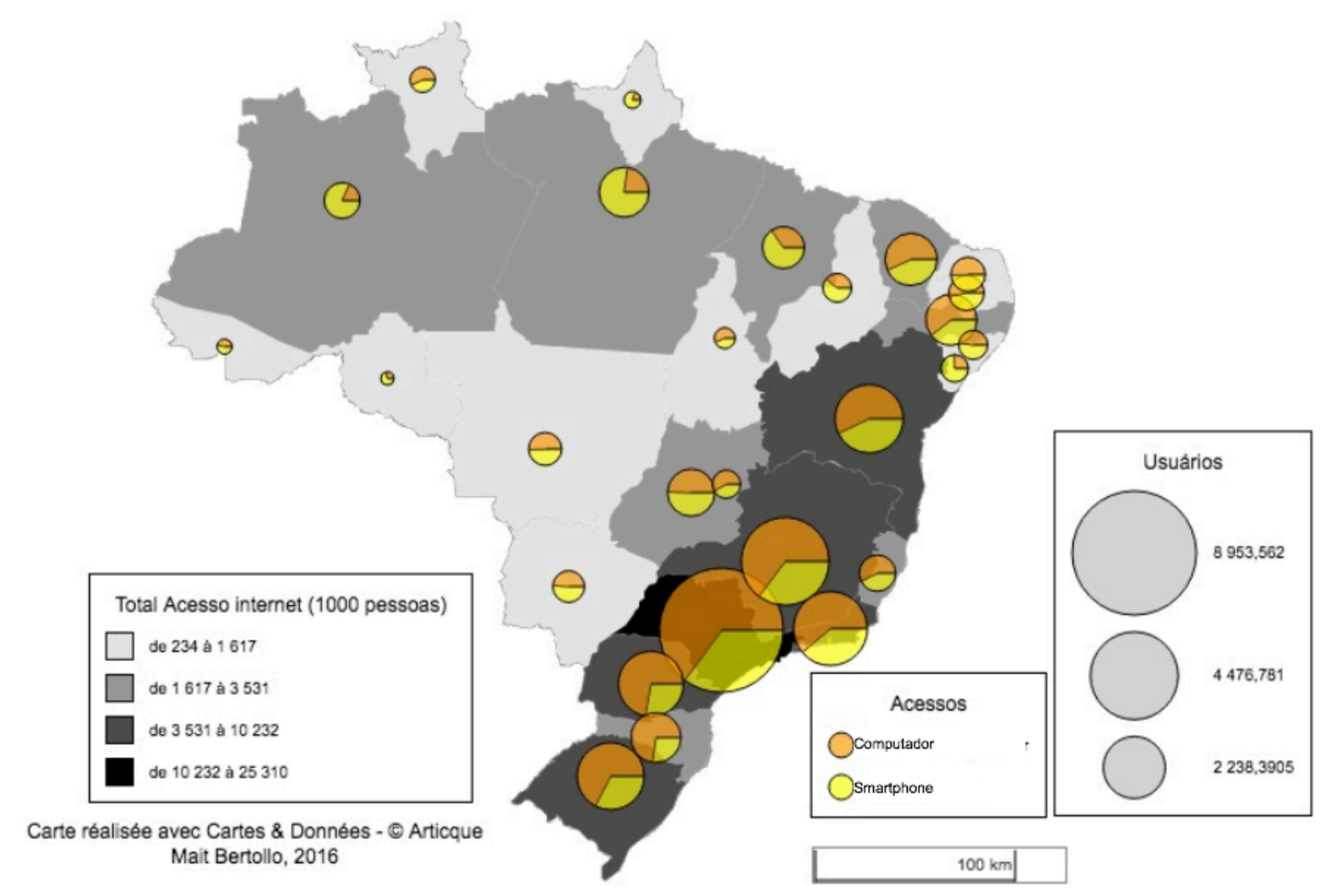

Fonte: IBGE (2016b).

Elaboração: Mait Bertollo.

A maioria dos acessos por computador concentra-se nos estados do Sul e do Sudeste, ao contrário dos estados da região Norte e de parte dos da região Nordeste, que usam essencialmente smartphone. Esse dado pode demonstrar que o maior uso de smartphones (pelas redes 2G, 3G e, em menor número, $4 \mathrm{G}$ ) nessas porções se deve à falta de infraestrutura de redes por fibra ótica, presentes sobretudo nas capitais e cidades de maior porte dos estados do Sul e do Sudeste. Onde não há redes legadas historicamente, usa-se a rede formada fundamentalmente por antenas que transmitem sinal $2 \mathrm{G}$ ou $3 \mathrm{G}$. 
Mapa 13 - Anamorfose dos usuários de smartphone, por unidade da federação, Brasil, 2016

Fonte: IBGE (2016b).

Organização: Mait Bertollo.

Elaboração: Hervé E. R. Thery.

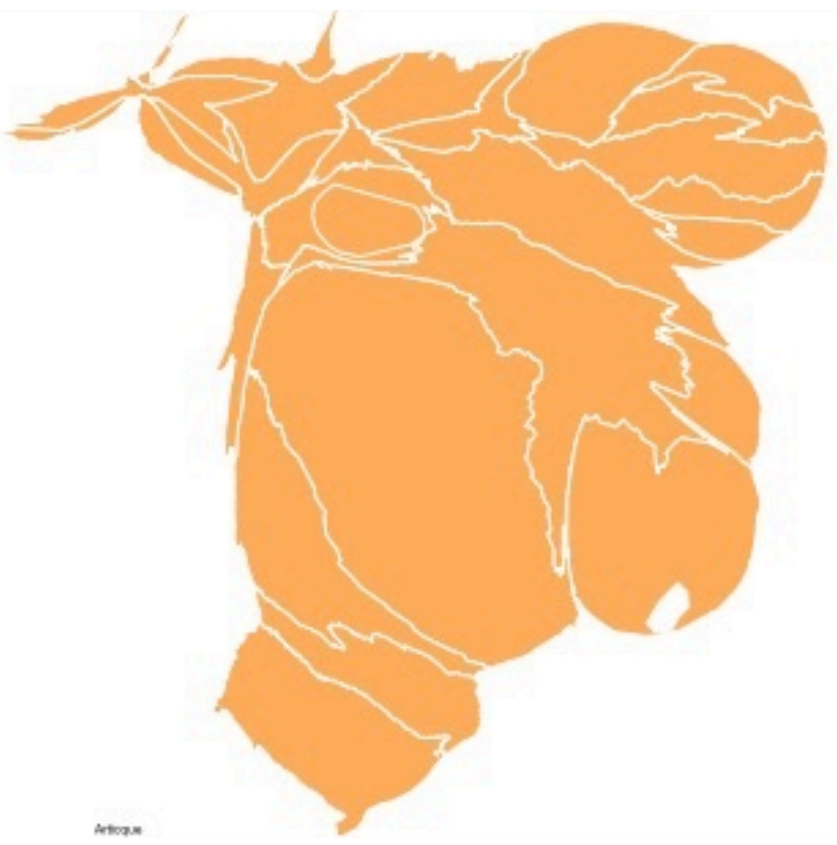

O Mapa 13 mostra a concentração de usuários de smartphone por unidade da federação, destacando-se o estado de São Paulo, seguido pelo do Rio de Janeiro. A região Norte é a que tem o menor número de usuários desse equipamento.

Uma das virtudes da anamorfose na representação do espaço geográfico é mostrar as proporções e os fluxos de informação. Vê-se no Mapa 13 que há mais capacidade de fluidez de informações nos estados do Sul, do Sudeste e do Nordeste. Se tomarmos também os Mapas 11 e 12, veremos que as regiões metropolitanas são as grandes concentradoras dos smartphones no território brasileiro.

Uma vez que são smartphones em uso, supõe-se, segundo as representações, a dinâmica econômica tanto das empresas de telefonia da rede suporte como das corporações que fornecem a rede serviço.

O ponto central é o acesso que se provê a indivíduos, empresas e instituições aos vetores informacionais: acessam-se notícias, dados etc., e também se trocam informações em tempo imediato, simultâneo. O número de usuários em determinada parte do território e sua distribuição pelas cidades revela as dinâmicas espaciais, uma vez que também indica a densidade da interação entre indivíduos. 
O Mapa 14 relaciona a renda e o acesso à rede por meio do smartphone, o acesso ao próprio objeto e a qualidade da conexão.

Mapa 14 - Usuários de smartphone segundo a faixa de renda (em salários-mínimos), por unidade da federação e por região metropolitana, Brasil, 2016

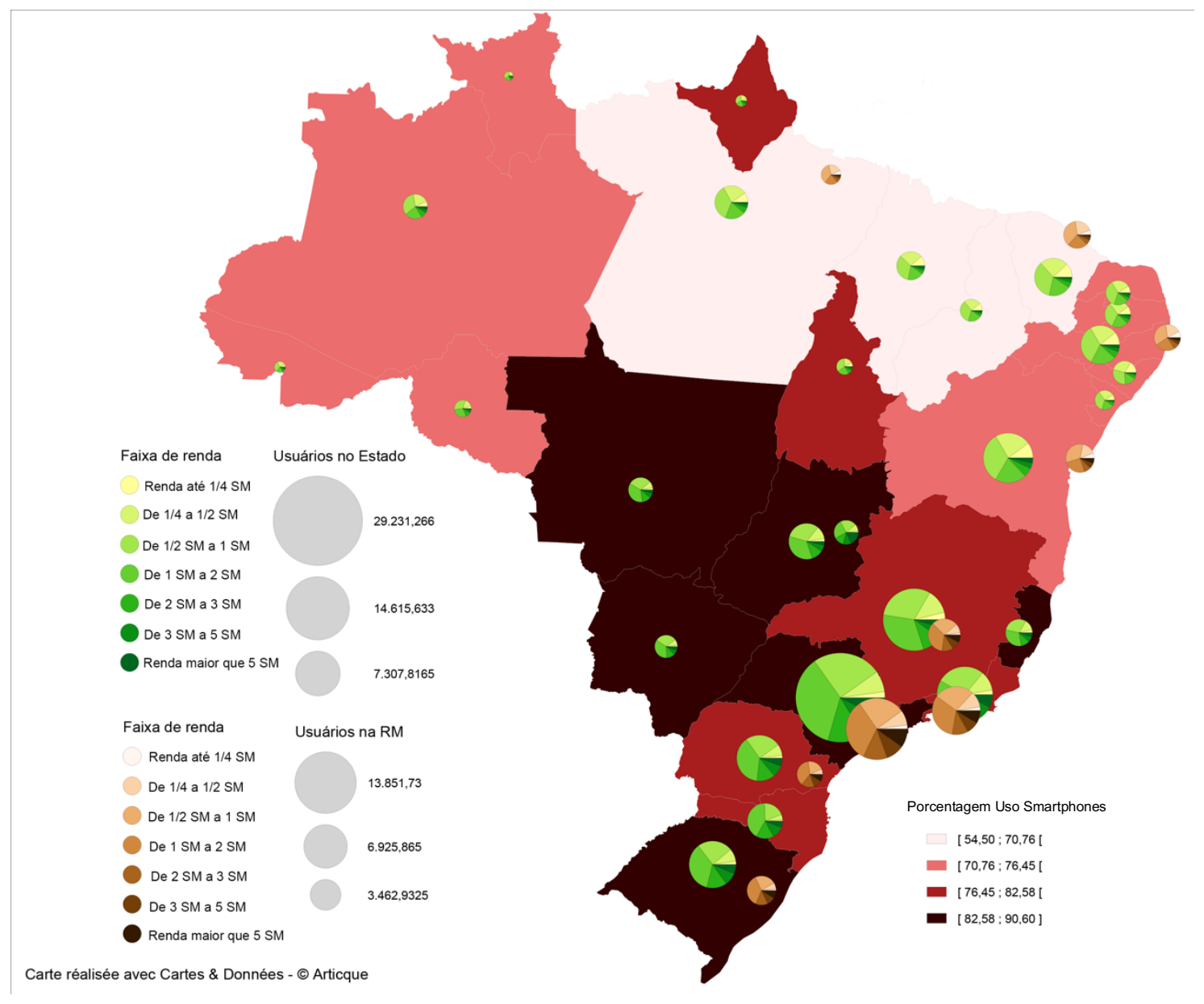

Fonte: IBGE (2016b).

Organização: Mait Bertollo.

Elaboração: Hervé E. R. Thery.

Isso mostra que algumas ações hegemônicas, sejam das corporações ou do Estado, se estabelecem e realizam por intermédio de objetos técnicos em determinadas porções do espaço que têm capacidade de retornar o valor investido.

Como se vê no Mapa 14, a maior densidade do uso de smartphones se verifica na população com maior renda, espacialmente aglomerada no Sudeste e no estado de São Paulo. Nas regiões Norte e Nordeste, onde o número de usuários é menor, o uso é mais concentrado em usuários com renda a partir de dois salários-mínimos. 
Os dados expõem o uso do smartphone no território e as possibilidades de interação espacial e participação dos indivíduos nessas redes técnicas, onde eles se relacionam, influenciam e são influenciados pelas articulações proporcionadas pelo vetor informacional.

Por meio do smartphone, os indivíduos produzem a contiguidade dessa rede, pois a capilarização da informação banal altera o tipo de interação espacial e pode produzir uma nova forma de realizar e/ou influenciar comportamentos em vários pontos e em centros urbanos, que são a principal base territorial desse sistema técnico que promove a instantaneidade e simultaneidade.

\subsection{Interações espaciais condicionadas pelo smartphone: difusor de informação e motivador da comunicação}

Entendida como uma ação recíproca, a interação pode ser transitória ou permanente, segundo as materialidades e os aspectos que interagem. Há relação de causa e efeito com o espaço em ambos os casos, pois há uma transformação, um efeito novo. A interação transforma a materialidade ou aspectos que interagem:

Os elementos fixos, fixados em cada lugar, permitem ações que modificam o próprio lugar, fluxos novos ou renovados que recriam as condições ambientais e as condições sociais, e redefinem cada lugar. Os fluxos são um resultado direto ou indireto das ações e atravessam ou se instalam nos fixos, modificando a sua significação e o seu valor, ao mesmo tempo em que, também, se modificam. [...] Fixos e fluxos, interagindo, expressam a realidade geográfica, e é desse modo que conjuntamente aparecem como objeto possível para a Geografia (SANTOS, 1999, p. 123).

As interações espaciais são componentes do espaço geográfico que têm a propriedade de atenuar, intensificar e transformar processos preestabelecidos e se refletem nas transformações espaciais, com desenvolvimentos desiguais do espaço, constituindo um amplo e complexo conjunto de deslocamento de pessoas, mercadorias, capital e informação sobre o espaço geográfico e podem manifestar maior ou menor intensidade, com maior ou menor frequência, distância e diversas direções e velocidades. Logo, as interações espaciais são parte da reprodução e processo de transformação social (CORRÊA, R., 1997).

É através das de redes que as interações espaciais efetivamente se realizam, a partir dos atributos dos lugares e das possibilidades, como no caso da capilarização da internet e das 
informações pelo uso do smartphone, que são uma forma de compreender a espacialidade humana em sua manifestação comunicacional.

Consideramos aqui que a comunicação é a troca de informações (estímulos, imagens, símbolos, mensagens) possibilitada por um conjunto de regras explícitas ou implícitas, que são os códigos, e que toda cultura é uma estrutura de comunicação que só pode ser compreendida pela decifração de seu código (SODRÉ, 1976). Assim, o fenômeno da cultura de massa só se viabilizou com o desenvolvimento do sistema de comunicação por mídia, com o progresso e a multiplicação de veículos de massa como jornais, televisão, rádio, filmes, discos, revistas e, no começo do século XXI, sites e aplicativos conectados à internet, aliados aos fenômenos de urbanização, formação de públicos de massa e aumento da necessidade de lazer.

O que se convencionou chamar cultura de massa tem como pressuposto, e como suporte tecnológico, a instauração de um sistema moderno de comunicação (os mass media, ou veículos de massa) ajustado a um quadro social propício (SODRÉ, 1976, p. 11).

A informação é interpretada como um instrumento para ordenar (ou reordenar) a experiência social do indivíduo "promovendo o seu convívio, já que a informação tem uma função política, no sentido de constituição ou formação da polis" (SODRÉ, 1976, p. 19). O produto da cultura de massa é resultado das intencionalidades do sistema comunicador, definidas pela publicidade, pelas ideologias predominantes, pelos interesses das empresas de comunicação etc., que condicionam as relações entre o produtor da obra e o consumidor, gerando uma mensagem específica (SODRÉ, 1976, p. 19).

O uso banalizado do smartphone, objeto de comunicação e informação de uso individual, privado e subjetivo, pode ser fixo e ao mesmo tempo fluxo - é um veículo contemporâneo da cultura de massa. Ele é a ponta da capilarização da rede de internet e favorece interações escalares do global ao local que se difundem, de certa maneira, por todos os estratos sociais da população brasileira: 
Na qualidade de "máquina desejante" capaz de criar ordem não apenas em seu próprio interior, mas também em seu entorno, o corpo humano é ativo e transformador em relação aos processos que o produzem, sustentam e dissolvem. Logo, as pessoas corporificadas dotadas de capacidades semióticas e vontade moral tornam seu próprio corpo um elemento fundacional naquilo que há muito chamamos de "corpo político" [...]. A organização, a mobilização e a canalização dos desejos humanos, o envolvimento político ativo com táticas de persuasão, vigilância e coerção tornam-se parte do aparato de consumo capitalista, produzindo por sua vez todo tipo de pressão sobre o corpo como sede de "consumo racional", bem como seu agente performativo, para fins de maior acumulação (HARVEY, 2004, p. 138/153).

A distribuição desse uso por compartimentos do espaço estruturados a partir da divisão social e territorial do trabalho e das divisões políticas é um dos elementos funcionais da expansão do capital, tanto as divisões internas dos territórios nacionais quanto as divisões em formações socioespaciais e Estados territoriais do planeta.

Segundo Smith (1988), três escalas são funcionalizadas pelo capital (ao mesmo tempo em que também impõem restrições): a escala urbana, a escala do Estado-nação e a escala global. A escala global corresponde à universalização do trabalho, onde o capital estabelece condições próprias para existir e se reproduzir, e a escala do Estado-nação é onde transcorrem as dinâmicas da universalização do capital. A incidência na escala urbana brasileira tem várias repercussões, em virtude da organização política federativa com as diferentes legislações (tributárias, fiscais, ambientais etc.) e das fronteiras internas que circunscrevem espaços políticos com poder de legislar.

\subsection{Incidência das normas nas cidades: empresas de telecomunicação, Estado e o condicionamento do uso das redes}

As normas desse conjunto complexo de redes e os agentes que as comandam determinam os papéis do Estado, das empresas, das organizações não governamentais e da sociedade civil organizada no uso do território para diversos interesses em várias escalas. Assim, a "regulação do território é híbrida porque há vários agentes em seu exercício. Eles produzem, é bom frisar, normas jurídicas, leis; e não somente condicionamentos conjunturais por mecanismos de pressão isolados” (ANTAS JR., 2005, p. 208).

Esses processos incidem diretamente nas cidades, que se transformam por meio de sucessivas combinações de objetos técnicos, fixos e fluxos que conectam sistemas urbanos e 
assim fomentam e mantêm a aceleração contemporânea. A cidade é um grande aglutinador de conjuntos de sistemas tecnológicos conectados à rede global de telecomunicações, base da produção e das trocas globais, e ao mesmo tempo articula e oferece meios para que se generalize o uso do smartphone, que responde ao meio técnico-científico-informacional nas escalas global, nacional, regional e local, mas não está presente na extensão territorial que essas escalas frequentemente sugerem, e sim em manchas desse meio cuja ação se dá nessas escalas.

O Mapa 15 ressalta o papel dos centros urbanos como sistemas tecnológicos relacionados à rede global de telecomunicações e o papel relevante sobretudo do estado de São Paulo, onde a densidade de redes técnicas é maior.

Mapa 15 - Usuários de smartphone por unidade da federação, Brasil, 2016

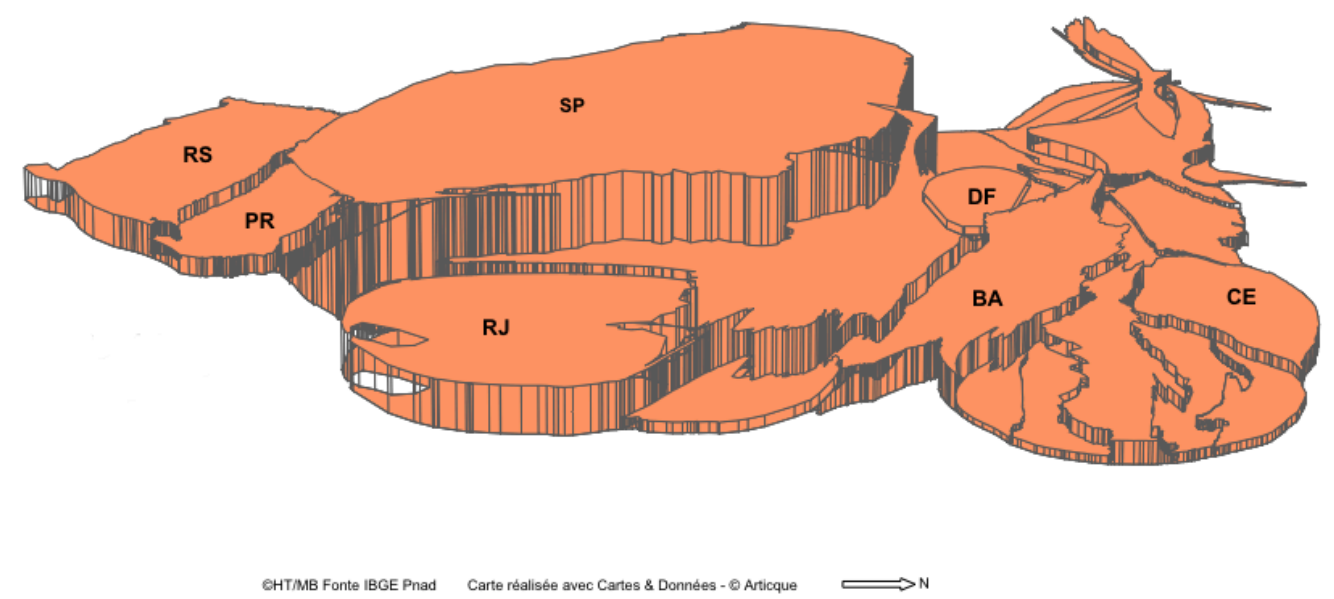

Fonte: IBGE (2016b).

Organização: Mait Bertollo.

Elaboração: Hervé E. R. Thery.

As cidades ampliam seu poder e passam de lugar do consumo e produção de bens materiais a ser também o lugar da circulação de todos os tipos de bens e informações, fundamentais nas estratégias de expansão dos negócios das corporações de telecomunicação.

A representação de mapas de concentração de iPhones (com sistema IOs) e de smartphones com sistema Android em cidades, baseados em 3 bilhões de tweets publicados desde 2011 (MapBox, 2016), mostra o peso que têm no espaço urbano esse objeto e as redes que o conectam à internet. 
Mapa 16 - Sistemas operacionais de smartphone na RMSP, 2016

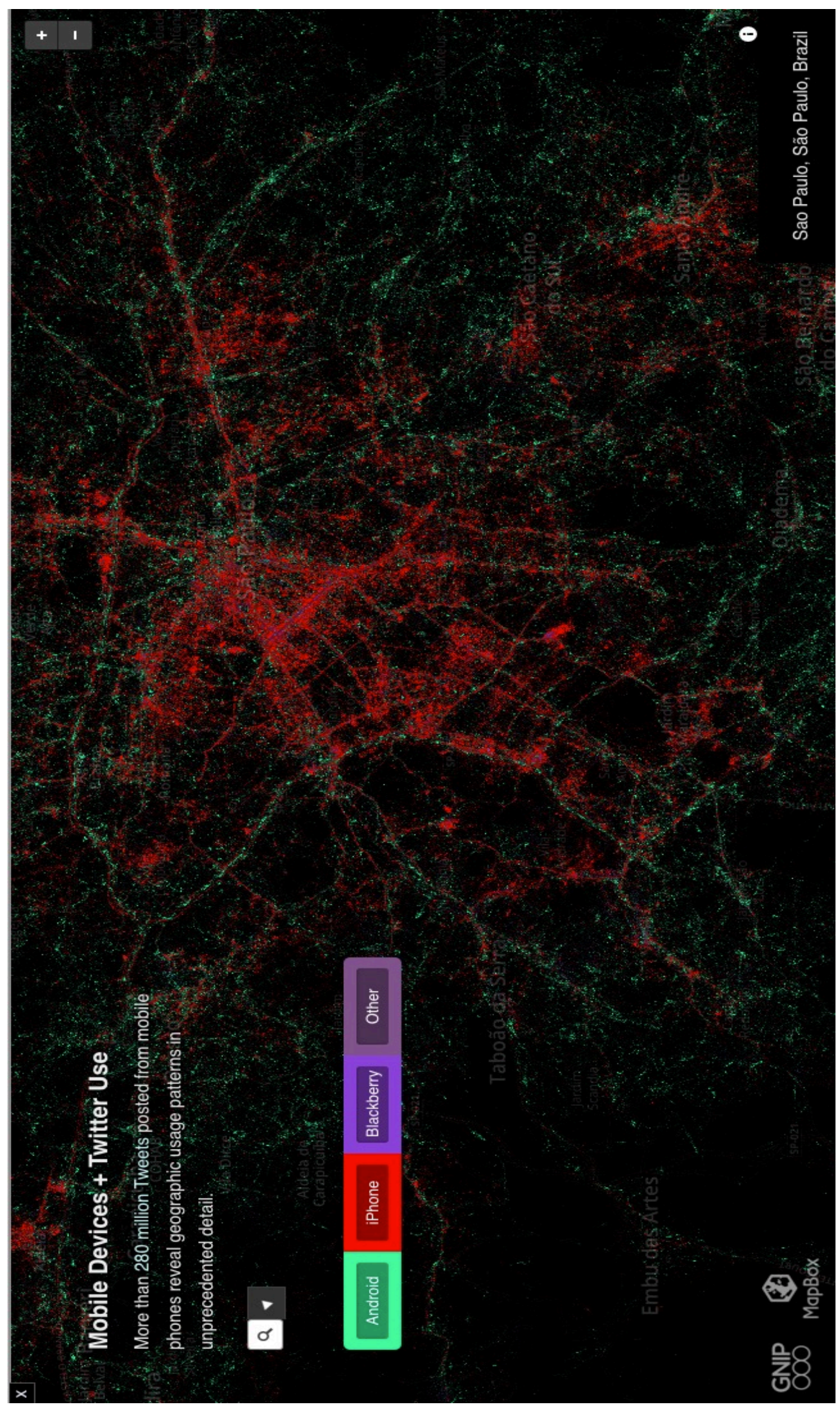

Fonte: MapBox (2016). 
Mapa 17 - Sistemas operacionais de smartphone nos estados de São Paulo e do Rio de Janeiro, 2016

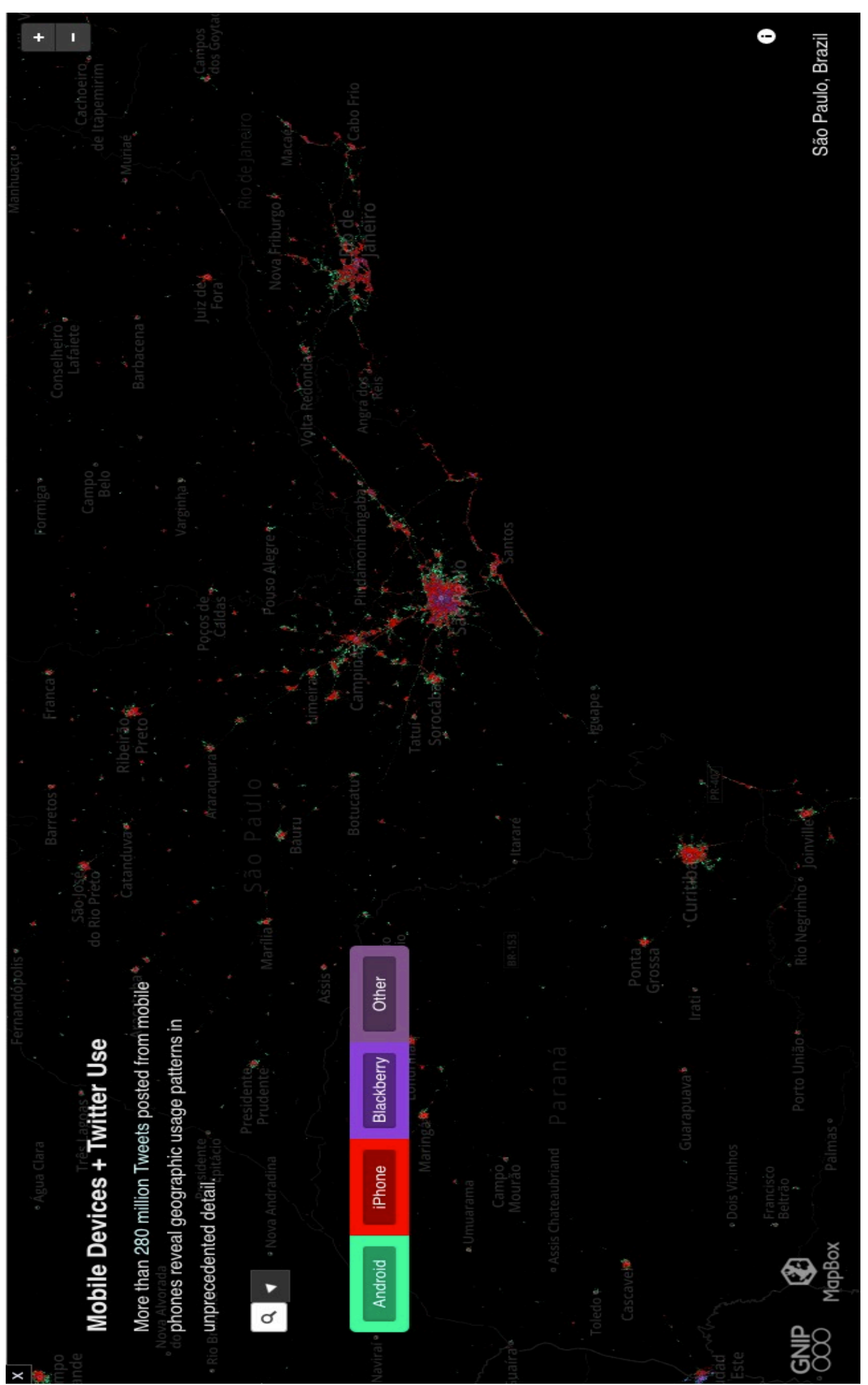

Fonte: MapBox (2016). 
Mapa 18 - Sistemas operacionais de smartphone no Brasil, 2016

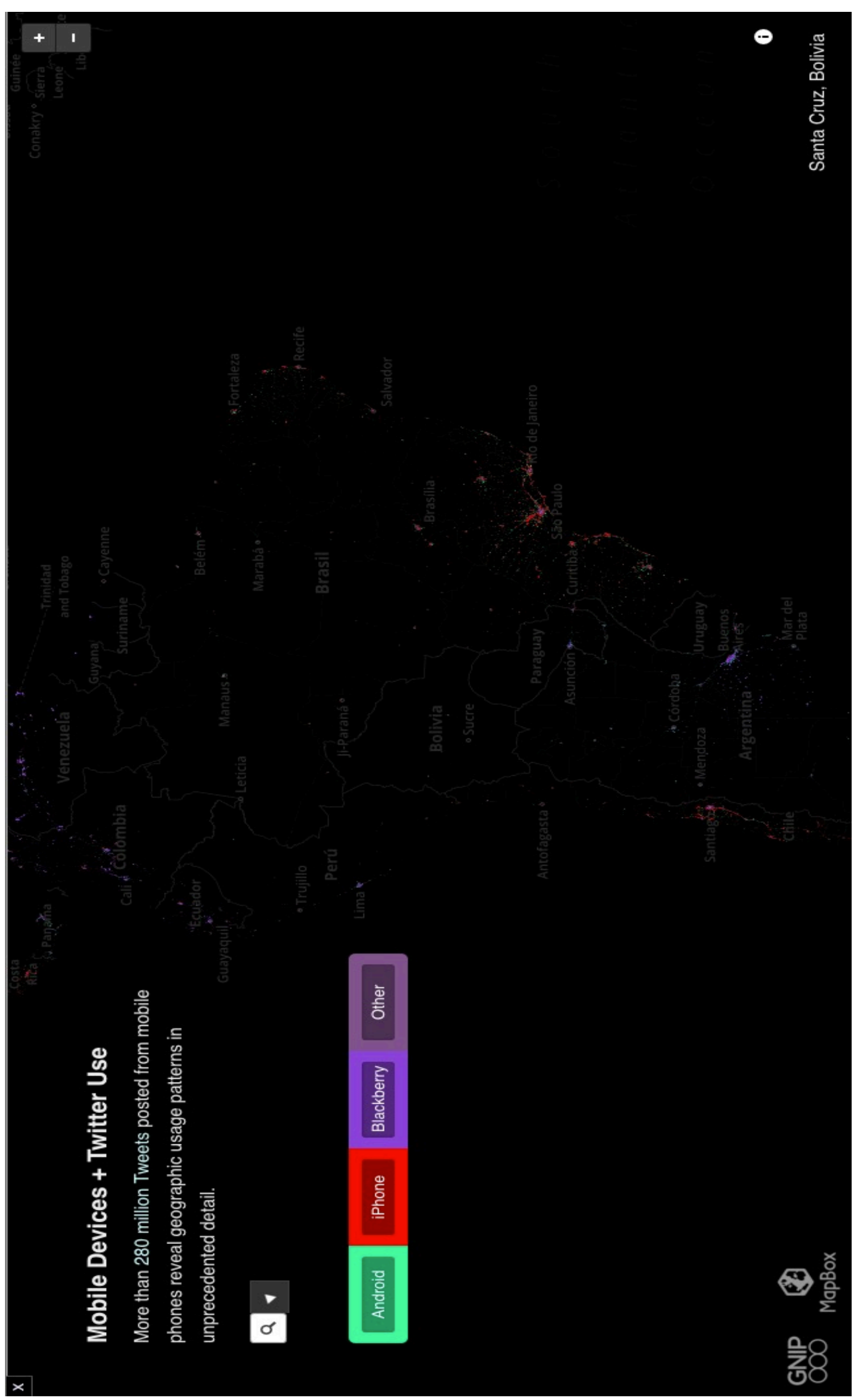

Fonte: MapBox (2016). 
Os Mapas 16, 17 e 18 apresentam os usos do smartphone por sistemas específicos que se concentram nas metrópoles, convergindo com outras redes como a rodoviária e a de grandes avenidas. O smartphone efetiva na cidade muitos e vários aplicativos que imergem os indivíduos nessa rede, capazes de promover uma multiplicidade de encontros e conexões que podem ser temporárias e reativáveis, em grupos diversos, realizados entre distâncias sociais, profissionais, geográficas e culturais.

Para Murray (2003) e Jenkins (2006), a participação nas redes sociais transforma a cultura contemporânea por meio da atuação coletiva dos indivíduos, principalmente nas cidades, o que transforma as práticas comunicativas tornando complexas as relações entre indivíduos e conteúdos digitais, sobretudo a partir das mudanças socioeconômicas expressas na disseminação das redes de internet no Brasil e no planeta.

Os indivíduos são expostos a várias experiências em seu cotidiano, relativas a novos dispositivos, novas plataformas ou novas aplicações que permitem interatividade e compartilhamento, em diversos níveis, entre pessoas e máquinas, gerando diferentes usos, apropriações e comportamentos individuais e coletivos.

O aumento dos acessos móveis no Brasil desde a última década mostra a densidade de uso e de transformações nas práticas comunicativas (Gráfico 4).

Gráfico 4 - Acessos móveis no Brasil, em milhões, 2016

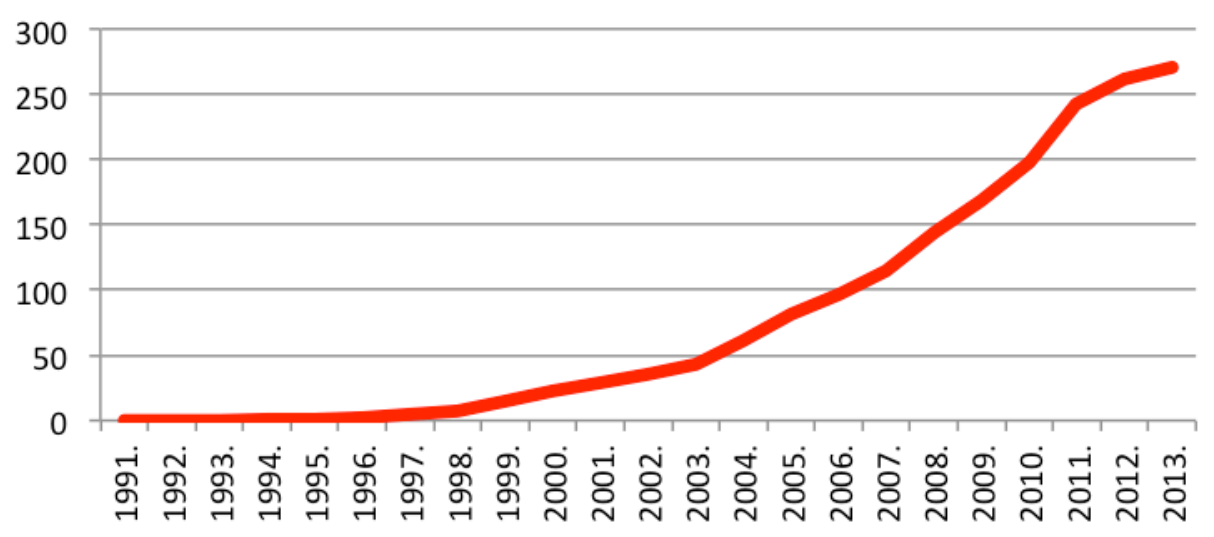

Fonte: Atlas Brasileiro de Telecomunicações (2016).

Elaboração: Mait Bertollo.

No Gráfico 4, verifica-se o importante aumento dos acessos móveis no Brasil no início do século XXI, conferindo às cidades, sobretudo às metrópoles, a base para consolidar e adensar as redes. A pressão por mais conectividade nas porções com mais habitantes e 
empresas induziu a implementação de aparatos técnicos como ERB, cabeamentos etc. para o acesso à rede serviço.

Gráfico 5 - Cobertura das principais empresas de telecomunicação no Brasil, por população e tipo de domicílio, 2016

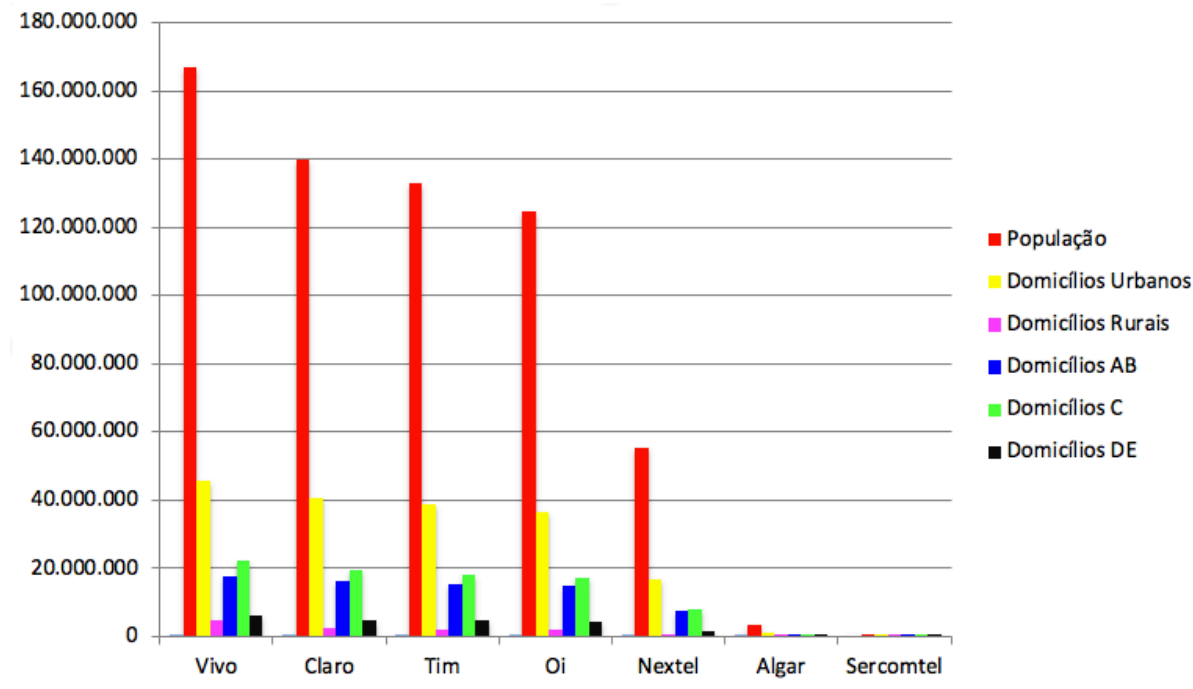

Fonte: Atlas Brasileiro de Telecomunicações (2016).

Elaboração: Mait Bertollo.

O Gráfico 5 mostra a capacidade de penetração das empresas Vivo, Claro, Tim e Oi, respectivamente em número de clientes. Nota-se que esse serviço é bastante usado em domicílios urbanos da classe $\mathrm{C}$, seguidos pela classe $\mathrm{AB} \cdot{ }^{39}$ Os domicílios de classe $\mathrm{DE}$ são bem menos expressivos, bem como os domicílios rurais, o que confirma que as grandes operadoras implantam redes prioritariamente em cidades e regiões mais populosas e povoadas e com renda capaz de custear esses serviços.

No Brasil, a implementação e o uso da rede 4G começaram em 2013 e ainda estão em expansão. O Gráfico 6 mostra que essa rede se concentra em domicílios urbanos de renda $\mathrm{AB}$ e C e que ainda não está disponível para domicílios rurais. É expressiva a atuação das empresas Claro e Vivo no fornecimento desse serviço. A cobertura $4 \mathrm{G}$ é oferecida apenas a municípios com mais de 30 mil habitantes (ANATEL, 2017b) e está presente em 558 municípios com 55\% da população economicamente ativa, ou seja, 9,6\% do total de 5.770 municípios (CONVERGÊNCIA DIGITAL, 2016).

\footnotetext{
${ }^{39} \mathrm{Na}$ classe de renda pesquisada, o Atlas Brasileiro de Telecomunicações (2016) define os estratos de renda A e B num mesmo grupo, e faz o mesmo com as classes D e E.
} 
Gráfico 6 - Abrangência da rede 4G no Brasil, por população e tipo de domicílio, 2016

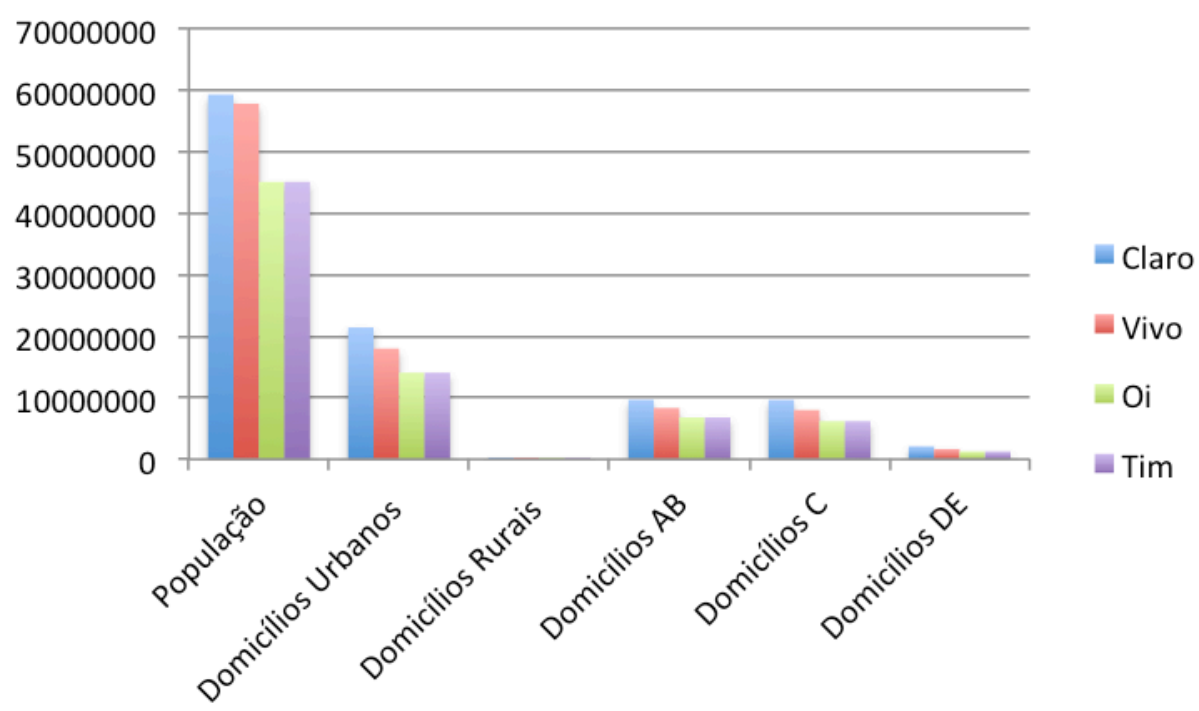

Fonte: Atlas Brasileiro de Telecomunicações (2016).

Elaboração: Mait Bertollo.

Gráfico 7 - Cobertura 2G, 3G e 4G entre 2005 e 2013, por número de municípios, Brasil

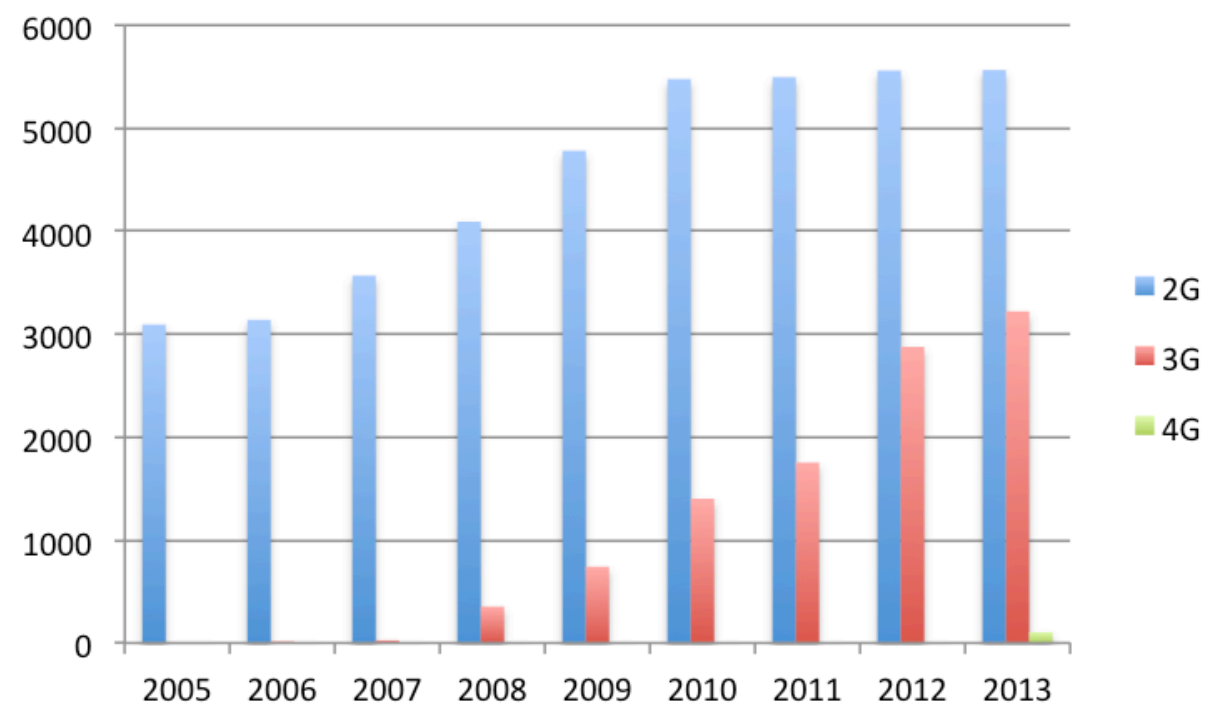

Fonte: Atlas Brasileiro de Telecomunicações (2016).

Elaboração: Mait Bertollo.

Observam-se, no passar do tempo, a continuidade e a predominância do uso da segunda geração de conexão $(2 \mathrm{G})$ e a chegada da terceira geração $(3 \mathrm{G})$ aos municípios a partir de 2008. A quarta geração é implementada em 2013. 
A segunda geração foi implantada na década de 1990, simultaneamente ao sinal digital; ainda utilizada mundialmente, é o recurso mais básico de conversação, por oferecer as ferramentas necessárias principalmente para a troca de mensagens de texto.

A popularização do uso do smartphone e dadas as suas múltiplas funções subordinadas ao funcionamento da internet e à capacidade de tráfego das informações, têm no atual período cifras que, relacionadas aos fluxos, crescem exponencialmente: entre 2014 e 2015, o tráfego global de informações foi equivalente a 127 bilhões de DVD: 11 bilhões por mês e 15 milhões por hora. A cada oito minutos, troca-se o mesmo volume de informação de todos os filmes já feitos no planeta, e o tráfego global em 2015 foi 21 vezes o de toda a internet em 2005. Numa escala global, esse montante informacional pode ser dividido por 5,9 gigabytes per capita. Em 2016, o total do tráfego ultrapassou a unidade zetabytes (10 $10^{21}$ bytes) (COMITÊ GESTOR DA INTERNET, 2016, p. 13).

Em escala nacional, o tráfego médio de internet cresceu 13\% por mês em 2015 e atingiu 1,7 exabytes por mês, o equivalente a 5 bilhões de DVD por ano. Em 2015, o volume de tráfego foi 150 vezes maior que em 2005 (COMITÊ GESTOR DA INTERNET, 2016). A magnitude desse volume de dados caracteriza um "dilúvio informacional” (LÉVY, 2000), em que a significância da informação no cotidiano altera as práticas da sociedade num contexto em que também aumentam sua criação e difusão.

No Brasil, em 2014, os smartphones se tornaram os aparelhos preferenciais para se conectar à internet, ultrapassando os computadores. A conexão chegou a $80,43 \%$ dos domicílios: 29,6 milhões dos 36,8 milhões de domicílios acessavam a rede por smartphone, e a porcentagem de computadores era de 63,3\% (IBGE, 2016b).

A restrição para aqueles que não estão conectados é o alto valor da conexão, seu preço por megabyte. Para satisfazer sua necessidade de comunicação e acesso à informação, a maioria dos usuários contrata planos pré-pagos.

No Mapa 19, verifica-se que a maior parte dos usuários de todas as unidades da federação usa planos pré-pagos para conectar-se à internet por smartphone. Em geral, se atribui esse comportamento ao alto custo do serviço, e esses planos permitem controlar melhor o uso. 
Mapa 19 - Número de usuários com acesso a telefonia móvel, por plano e por unidade da federação, Brasil, 2016

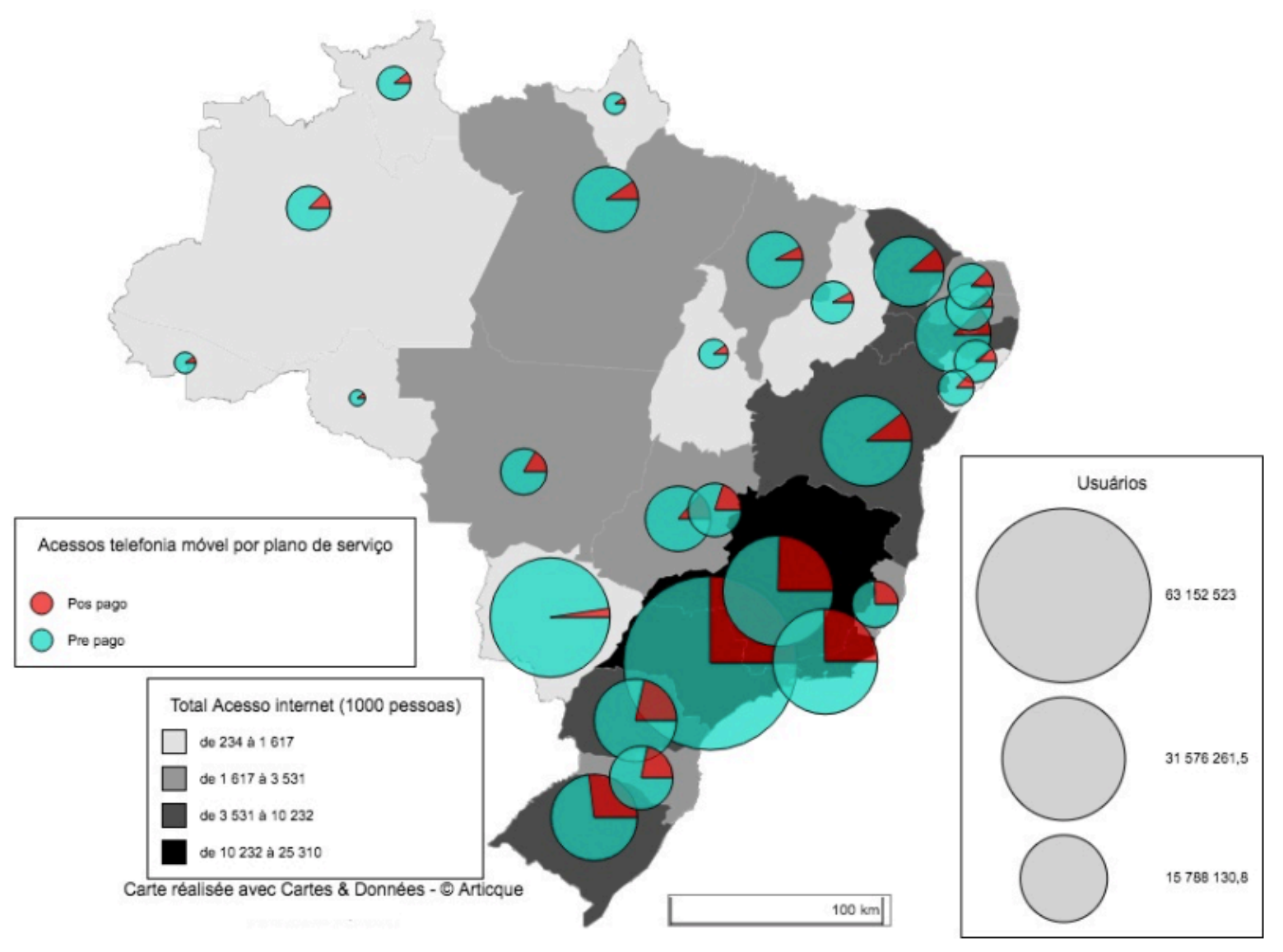

Fonte: Comitê Gestor da Internet (2016).

Elaboração: Mait Bertollo.

A crescente demanda de conexão e o não oferecimento de serviço de grandes empresas provedoras em regiões com menos infraestrutura, com menor densidade populacional e onde os habitantes têm menor poder aquisitivo resultou no surgimento de pequenos provedores ditos regionais, que atendem até 50 mil clientes e pagam menos pela licença de funcionamento (COMITÊ GESTOR DA INTERNET, 2016).

A maior participação de provedores regionais onde a conexão é insatisfatória e não há fornecimento de serviços pelas grandes empresas de telecomunicação faz parte das ações do Plano Nacional de Banda Larga, um movimento de capilarização das redes suporte pelo território para que provedores regionais possam fornecer o sinal e a conexão à rede serviço aos usuários de cada smartphone. Hoje, existem 9.174 provedores regionais (ANATEL, 2018b). No Mapa 20, vemos a mais recente distribuição dos provedores segundo seu porte, por unidade da federação no território brasileiro. 
Mapa 20 - Porte das empresas provedoras de internet, por número de pessoas ocupadas e por unidade da federação, Brasil, 2018

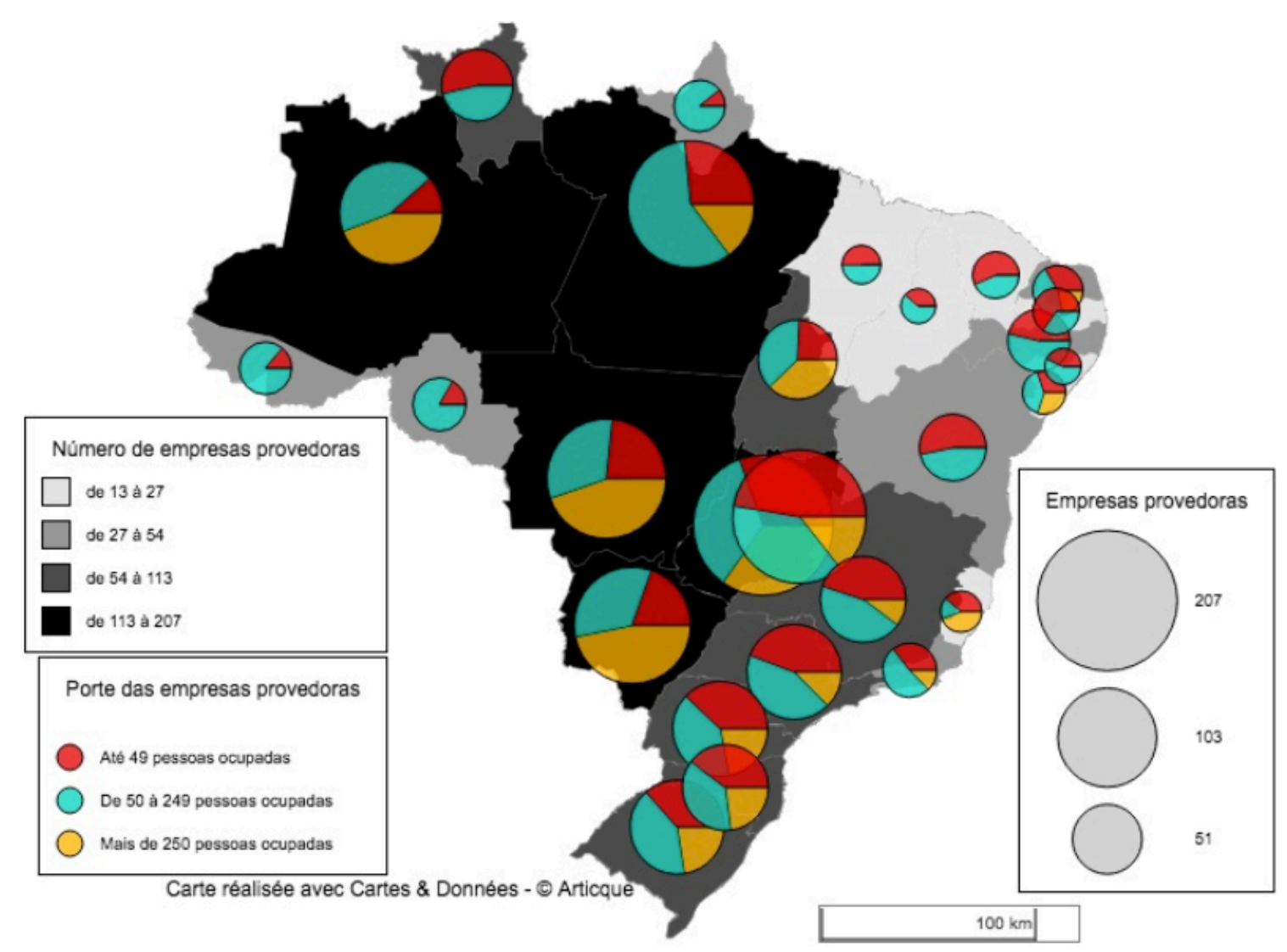

Fonte: Anatel (2018b).

Elaboração: Mait Bertollo.

O Mapa 20 mostra a importante atuação e influência dos provedores regionais na maior parte do território nacional. As cidades de 5 mil até 50 mil habitantes são as que mais usam o serviç̧o desses provedores e ficam principalmente nas regiões Norte e Nordeste, onde existe demanda de conexão, mas não atendimento por grandes empresas ou o valor do serviço é muito alto para a renda da população. No Gráfico 8, a distribuição dos provedores regionais por município, de acordo com o número de habitantes.

Em 2017, cresceu 30\% o número de clientes do mercado de acessos a internet móvel por provedores regionais (GROSSMAN, 2018), cuja receita líquida foi de cerca de R\$ 4 bilhões (MAGALHÃES, 2017), o que inclui o fornecimento de serviços para banda larga fixa, móvel e televisão a cabo para residências, negócios e usuários individuais. 
Gráfico 8 - Distribuição dos provedores regionais, por município e por número de habitantes, Brasil, 2017

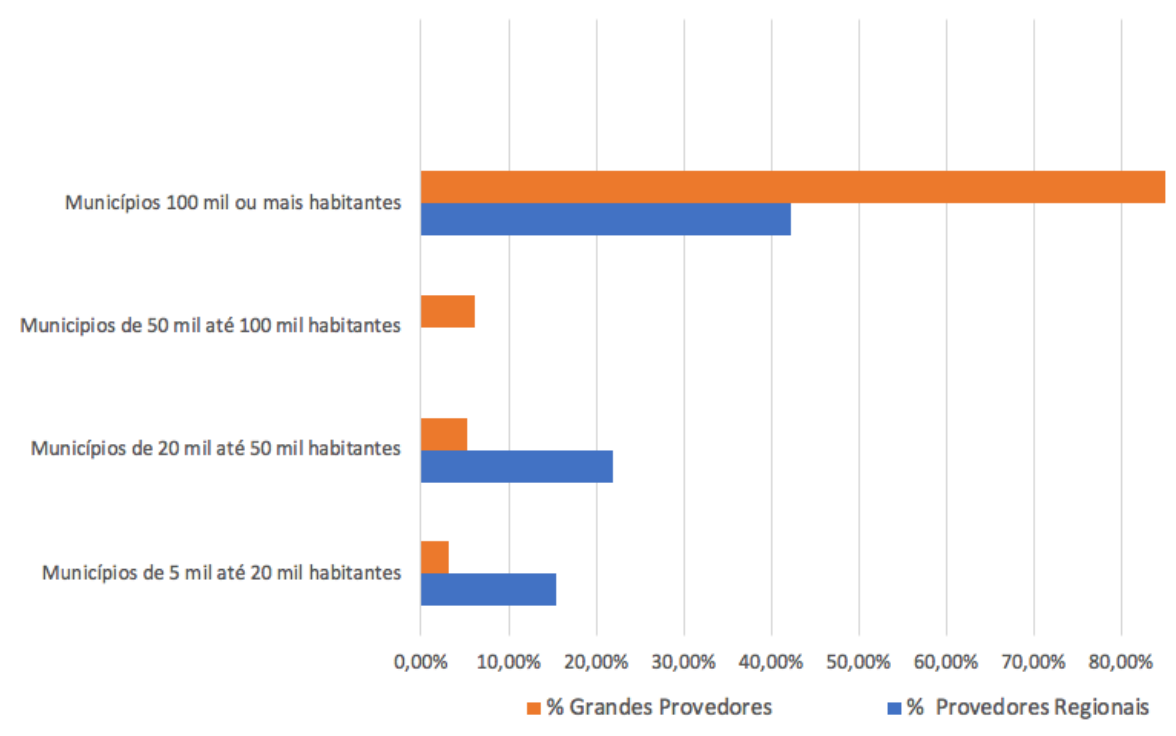

Fonte: Anatel (2018b).

Elaboração: Mait Bertollo.

Do total de acessos dos provedores regionais, 60\% provêm de municípios com até 100 mil habitantes, onde as grandes empresas suportam 15\% dos acessos. Não há backhaul de fibra ótica em 2.345 municípios no Brasil, e a maioria deles se concentra no norte do estado de Minas Gerais, no interior da região Nordeste e na região amazônica (ANATEL, 2017b).

\subsection{Uso do smartphone no território brasileiro: redes de conexão e acesso}

Definidoras da vida cotidiana e com crescente importância na circulação e comunicação de informações, as redes são produto e condição social, historicamente construídas e dotadas de intencionalidades. No caso da conexão do smartphone à internet, seu uso só se concretiza se existe uma conexão satisfatória.

Os usos do smartphone e a qualidade da conexão são diferenciados segundo a classe social, em que há marcas claramente definidas sobre quem tem acesso livre a variados tipos de serviços e quem não tem, impactando em vários âmbitos como no direito essencial ao acesso à internet, previsto no Marco Civil e na formação de opinião, por exemplo. 
A rede serviço é acessada por meio do smartphone principalmente por aplicativos; no Brasil, 83\% dos acessos são para mensagens instantâneas (COMITÊ GESTOR DA INTERNET, 2016). Há uma importante mudança nas práticas culturais e na comunicação entre as pessoas conectadas (Gráficos 9 a 13).

Gráfico 9 - Dispositivos de acesso no Brasil, em milhões de pessoas, por região, 2016

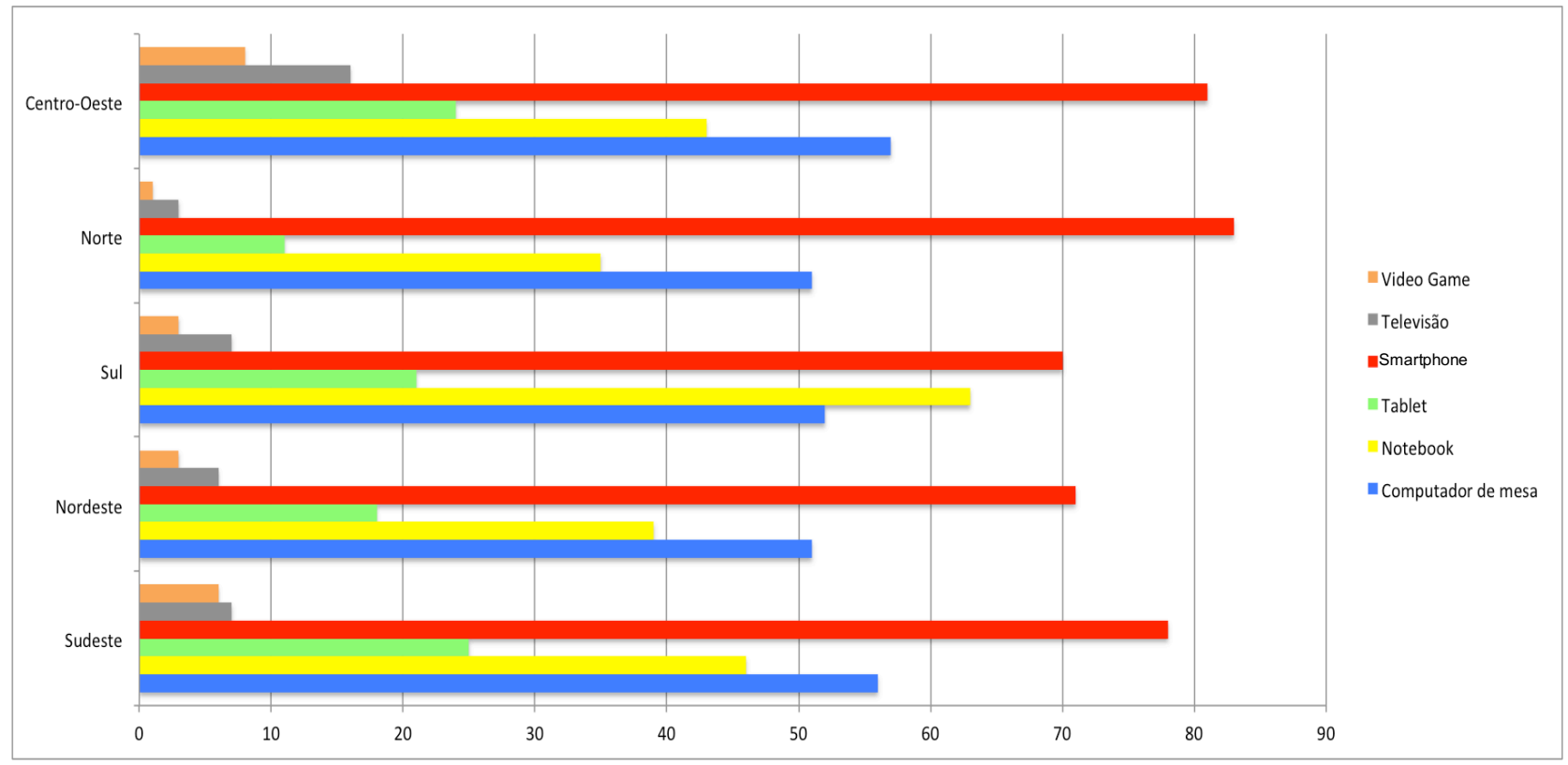

Fonte: Comitê Gestor da Internet (2016).

Elaboração: Mait Bertollo.

Quanto ao uso de dispositivos, o Gráfico 9 mostra a primazia do smartphone e seu peso no acesso à informação e à comunicação em todas as regiões brasileiras.

Gráfico 10 - Dispositivos de acesso no Brasil, em milhões de pessoas, por renda, 2016

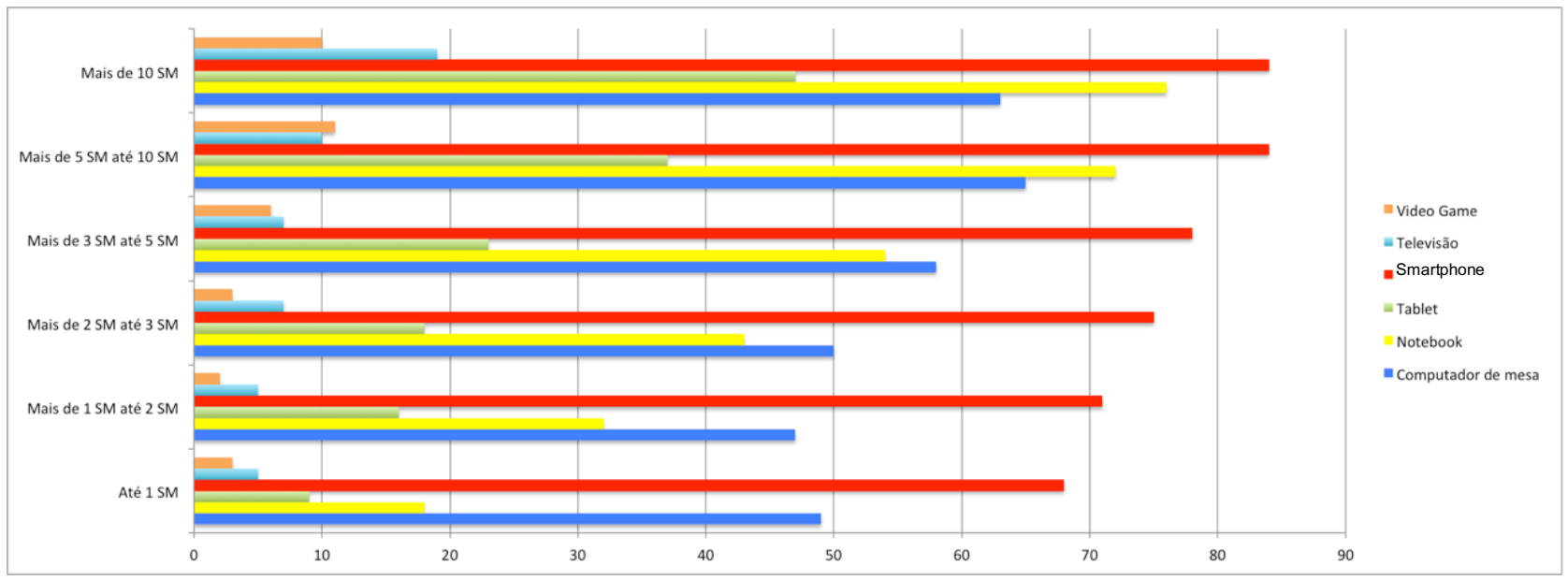

Fonte: Comitê Gestor da Internet (2016).

Elaboração: Mait Bertollo. 
Em todas as faixas de renda se usa smartphone, esse objeto que reúne as funções do telefone e de computador, e é esse e uso massivo que estabelece novas práticas de comunicação e da capilarização da informação no Brasil.

Gráfico 11 - Download, criação de conteúdo e compartilhamentos no Brasil, em milhões de pessoas, por região, 2016

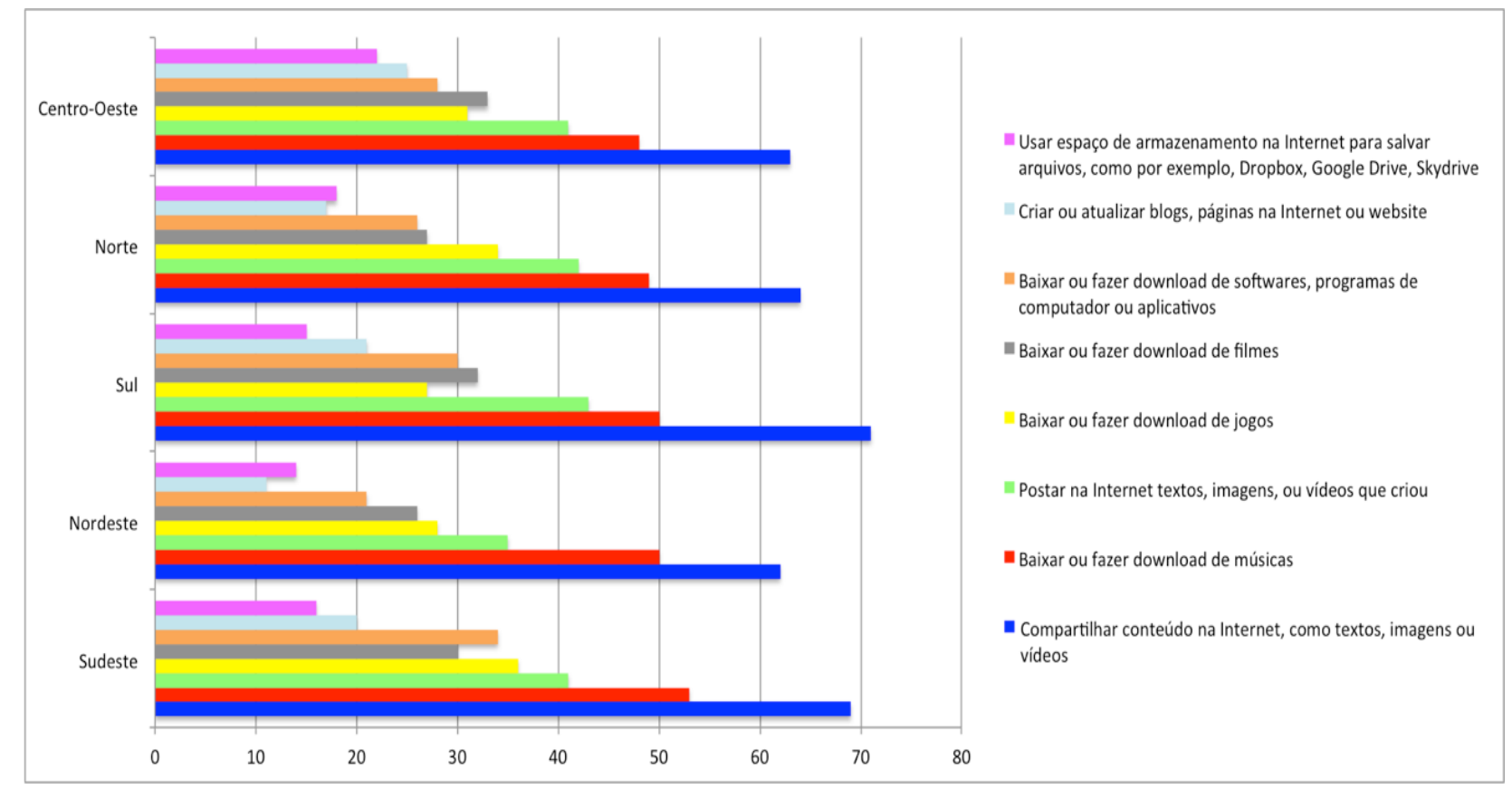

Fonte: Comitê Gestor da Internet (2016).

Elaboração: Mait Bertollo.

Segundo o Gráfico 11, em todas as regiões, a maior parte dos acessos visa compartilhar conteúdos, o que acontece por meio de redes sociais como o WhatsApp, em primeiro lugar. 
Gráfico 12 - Acessos para serviços ou busca de informações, em milhões de pessoas, por região, Brasil, 2016

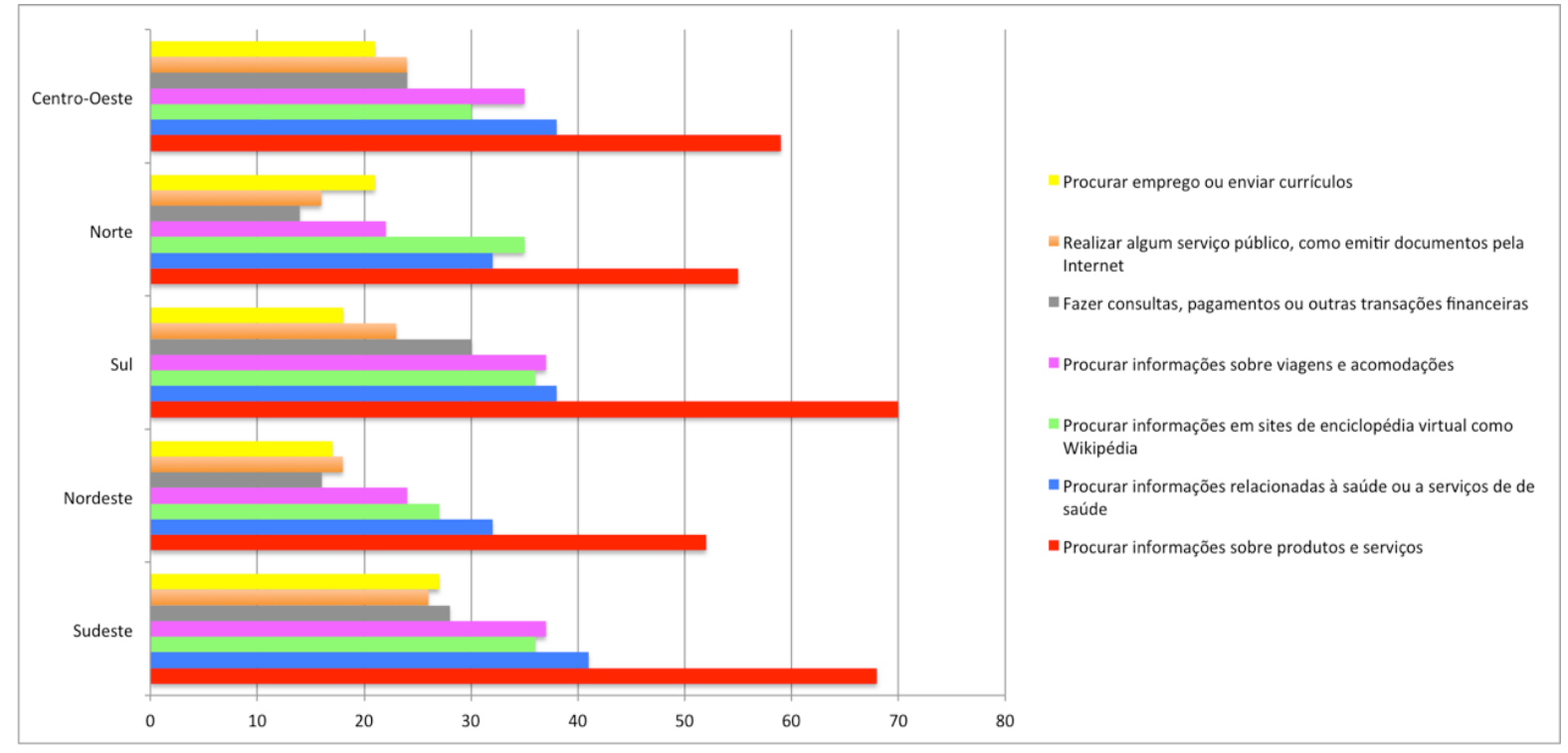

Fonte: Comitê Gestor da Internet (2016).

Elaboração: Mait Bertollo.

Em todas as regiões, a principal busca é de informações sobre produtos e serviços, o que indica vários tipos de atividade, principalmente comerciais, pela popularização do uso da internet. Outro serviço importante é a busca de informações sobre saúde e dos serviços correspondentes.

Gráfico 13 - Acessos à internet no Brasil, em porcentagem de pessoas, por renda, 2016

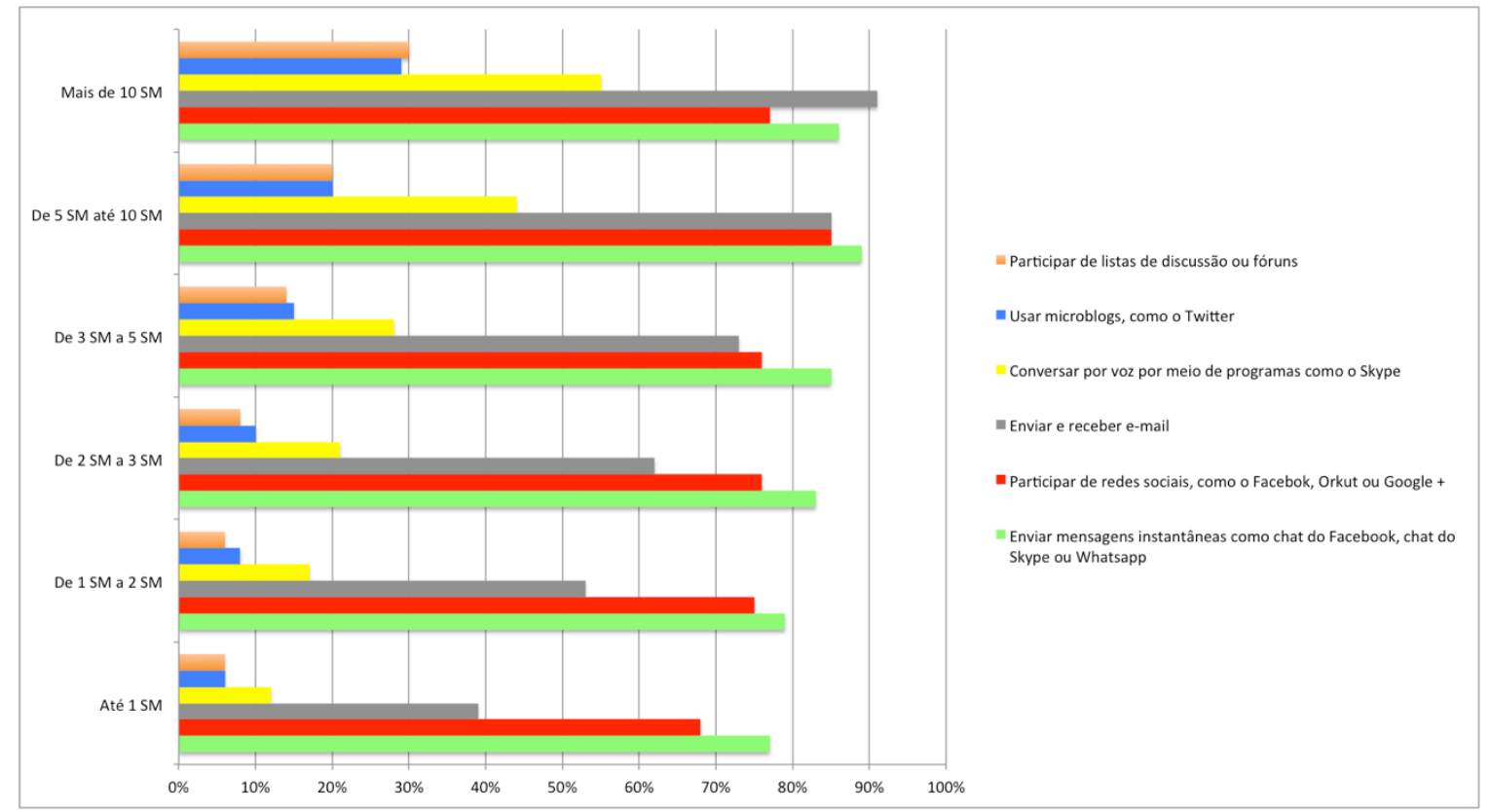

Fonte: Comitê Gestor da Internet (2016).

Elaboração: Mait Bertollo. 
Em todas as faixas de renda, prevalece o envio/recebimento de mensagens instantâneas por WhatsApp, Skype ou Facebook, mostrando a força desses aplicativos nas relações comunicacionais, substituindo cada vez mais os dados de voz. Em segundo lugar, está clara a força das redes sociais, sobretudo do Facebook, no cotidiano dos indivíduos e do coletivo.

Segundo o Gráfico 14, as atividades multimídia mais comuns são assistir filmes ou vídeos, seguida de ouvir música on-line e ler jornais ou revistas. Um dispositivo como o smartphone substitui vários aparelhos, concentrando-se nele importantes funções cotidianas.

Gráfico 14 - Atividades multimídia no Brasil, por região, 2016

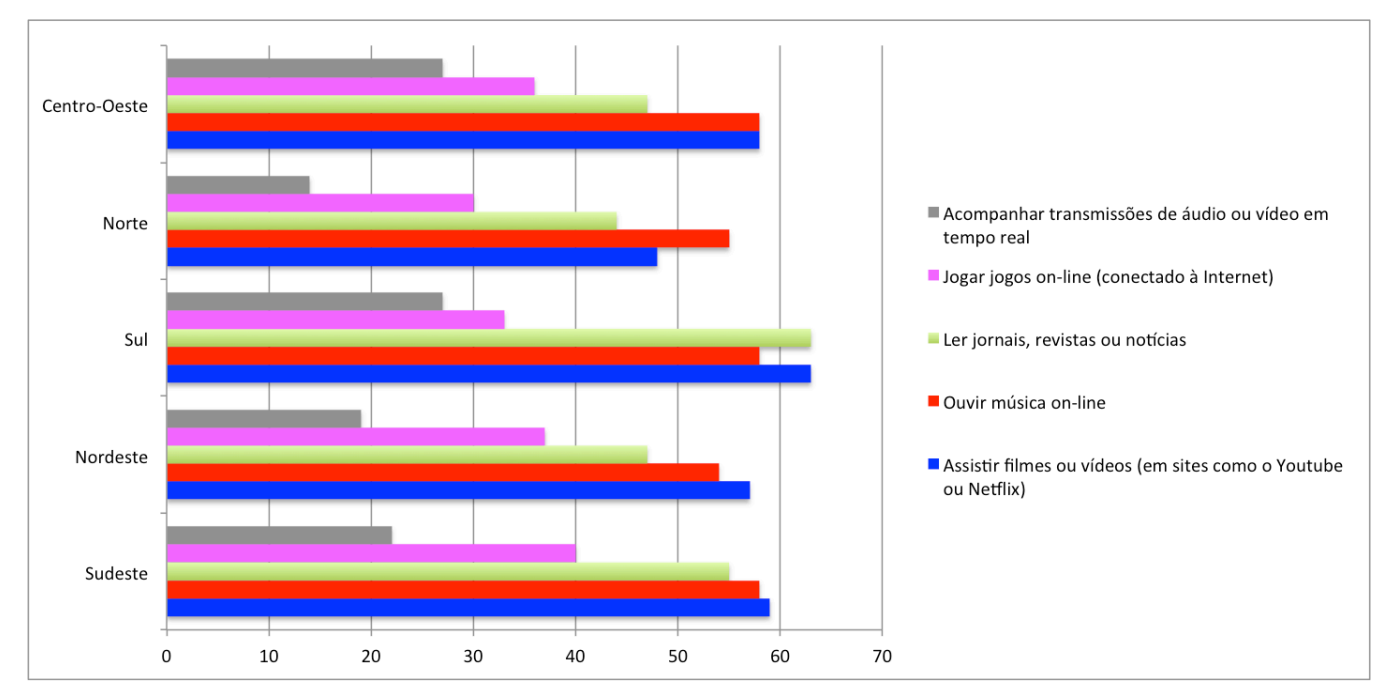

Fonte: Comitê Gestor da Internet (2016).

Elaboração: Mait Bertollo.

Com uso crescente, as redes sociais são ferramentas de propagação de informações que condicionam vários tipos de engajamento, potencializam debates e induzem o crescimento também do volume e da velocidade das informações produzidas em rede, conformando uma lógica da ação comunicacional e informacional no território. Para que essas redes sejam acessadas e também criadas, há um importante impacto dos componentes técnicos e políticos dessa infraestrutura imbricada que resulta em impactos territoriais. 
Segundo a Pesquisa Nacional por Amostra de Domicílios Contínua (PNAD) de 2016 (IBGE, 2016b), em 5,4\% dos domicílios não havia nenhum tipo de telefone, notadamente nas regiões Nordeste (10 \%) e Norte (11\%). No Centro-Oeste, são 2,4\% dos domicílios, no Sul $3 \%$ e no Sudeste $3,2 \%$.

Os smartphones estão presentes em 92,6\% dos domicílios do país, contra um pequeno número de telefones fixos em todas as regiões (Gráfico 15).

Gráfico 15 - Percentual de telefones fixos e smartphones nos domicílios, por região, Brasil, 2016

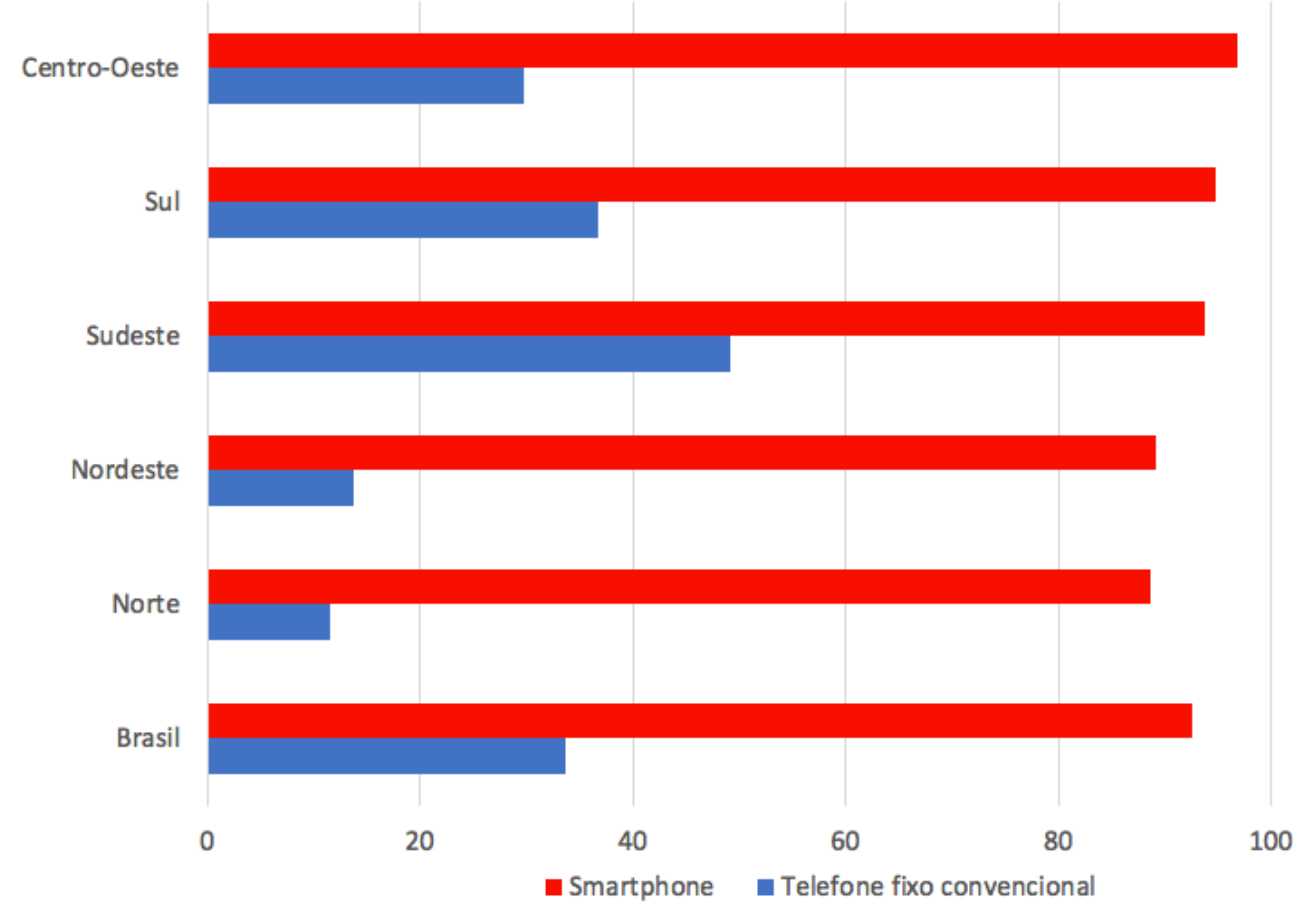

Fonte: IBGE (2016b).

Elaboração: Mait Bertollo. 
Mapa 21 - Relação entre população e número de smartphones no Brasil, por unidade da federação, 2016

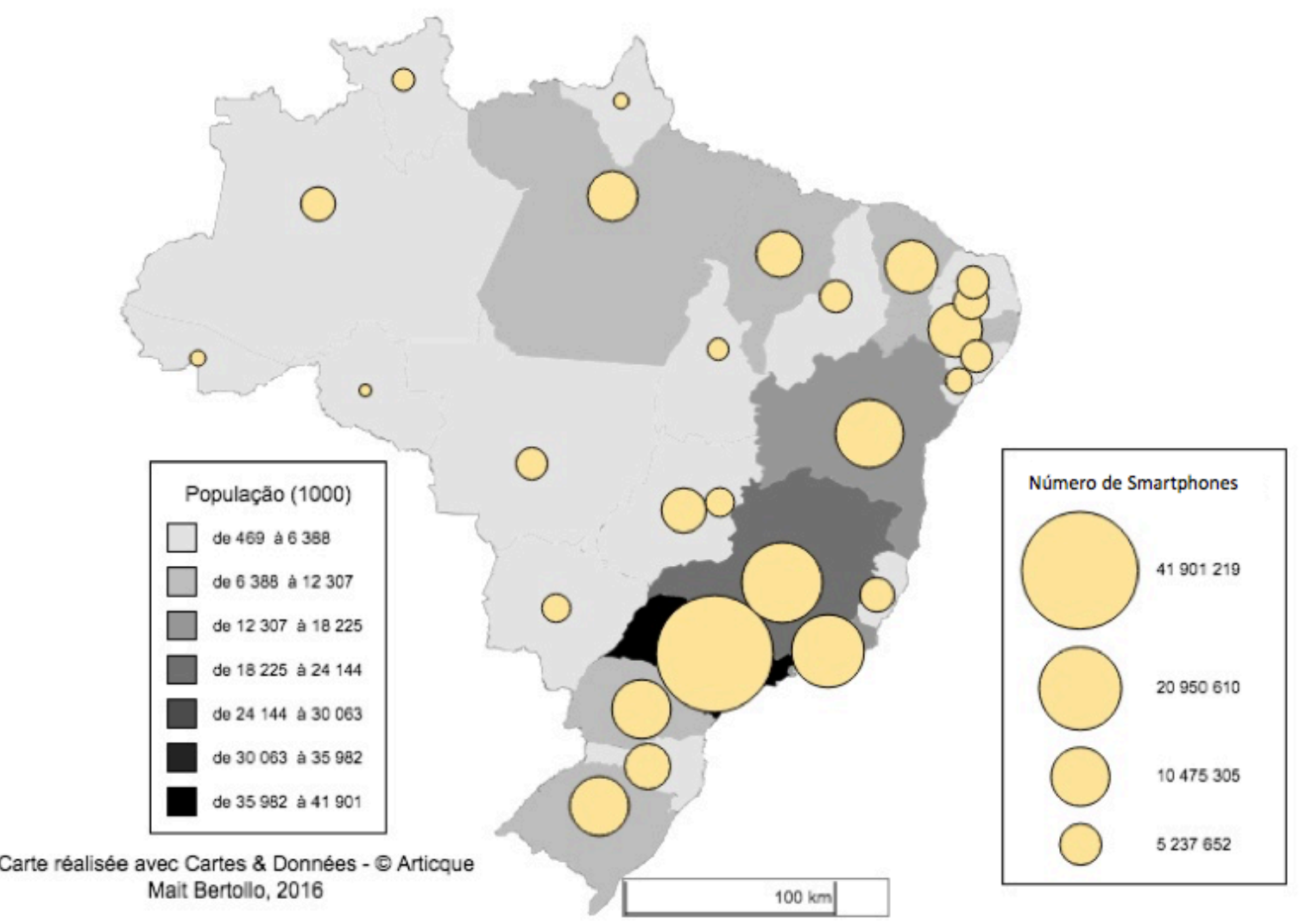

Fonte: Steinberger e Tofeti (2015).

Elaboração: Mait Bertollo.

O Mapa 21 apresenta o número de smartphones em relação ao número de habitantes por estado, o que produz a carga informacional denominada teledensidade, cujos valores são indicados e comparados no Gráfico 15. A rede é, por excelência, um instrumento de poder (RAFFESTIN, 1985) e ainda tem o potencial de operar e viabilizar mudanças ou fortalecer permanências (DIAS, 1995a). A rede de comunicação implementada favorece determinados arranjos espaciais em detrimento de outros, tornando densos certos fluxos e criando e aumentando a intensidade dos campos de força, integrando desigualmente os territórios, agravando assimetrias e seguindo o peso de atividades econômicas preexistentes (DIAS, 1995a).

No Gráfico 16, verifica-se que os estados do Nordeste têm a menor carga informacional entre as unidades da federação. No Maranhão, a teledensidade é menor, enquanto no Pará e no Distrito Federal há mais smartphones por habitantes. Isso caracteriza algumas porções do território como nós, que são os lugares de conexão, de poder e de referência (DIAS, 1995b). 
Gráfico 16 - Comparação entre a carga informacional das unidades federativas segundo a teledensidade

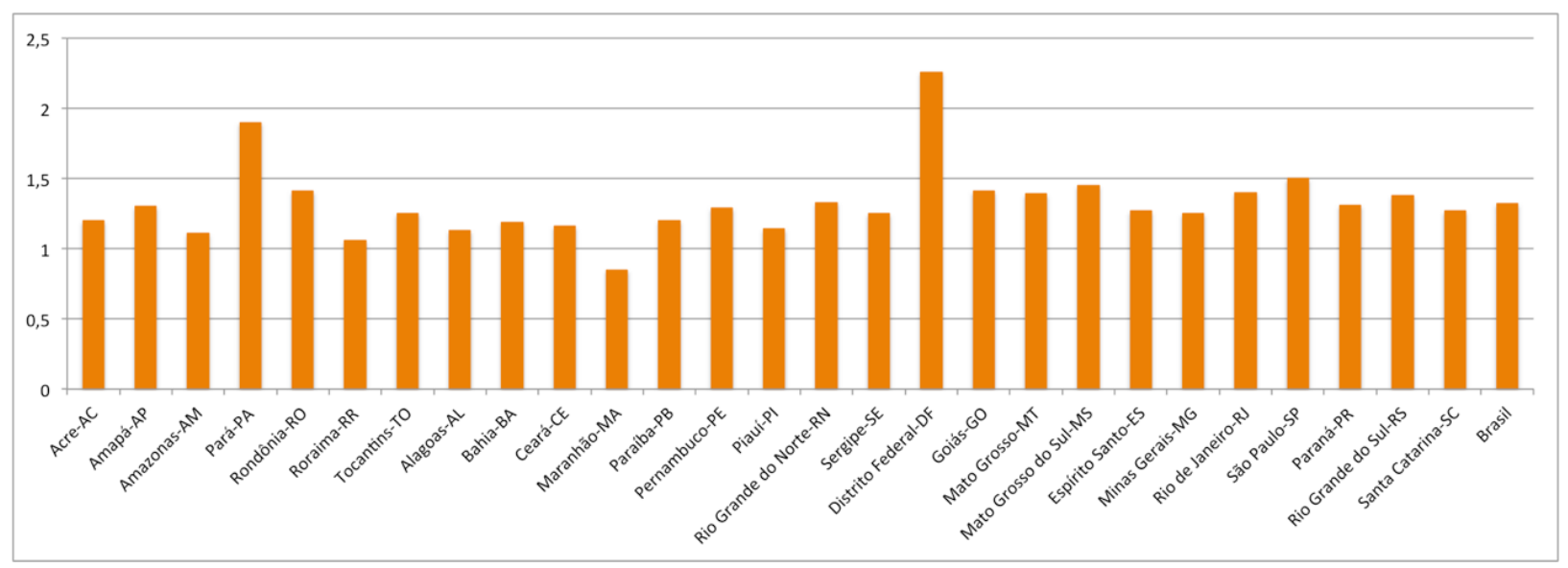

Fonte: Steinberger e Tofeti (2015).

Elaboração: Mait Bertollo.

Para permitir a conexão do smartphone, o território brasileiro está dotado de 92.116 ERB distribuídas desigualmente (TELEBRASIL, 2018) e utilizadas principalmente pelas grandes empresas de telecomunicação. As ERB foram mapeadas para verificar seu arranjo espacial a partir do banco de dados da Anatel. Aplicaram-se informações como o nome da operadora, seu CNPJ, o código e a localização de cada ERB (latitude e longitude em graus), o que permitiu mapear cada ponto e mostrar sua concentração nas áreas urbanas e em determinadas regiões e unidades federativas, seguindo o padrão de concentração da densidade técnica no Sul e no Sudeste e nas capitais das regiões Centro-Oeste, Nordeste e Norte. 
Mapa 22 - Distribuição das ERB no território brasileiro, 2018

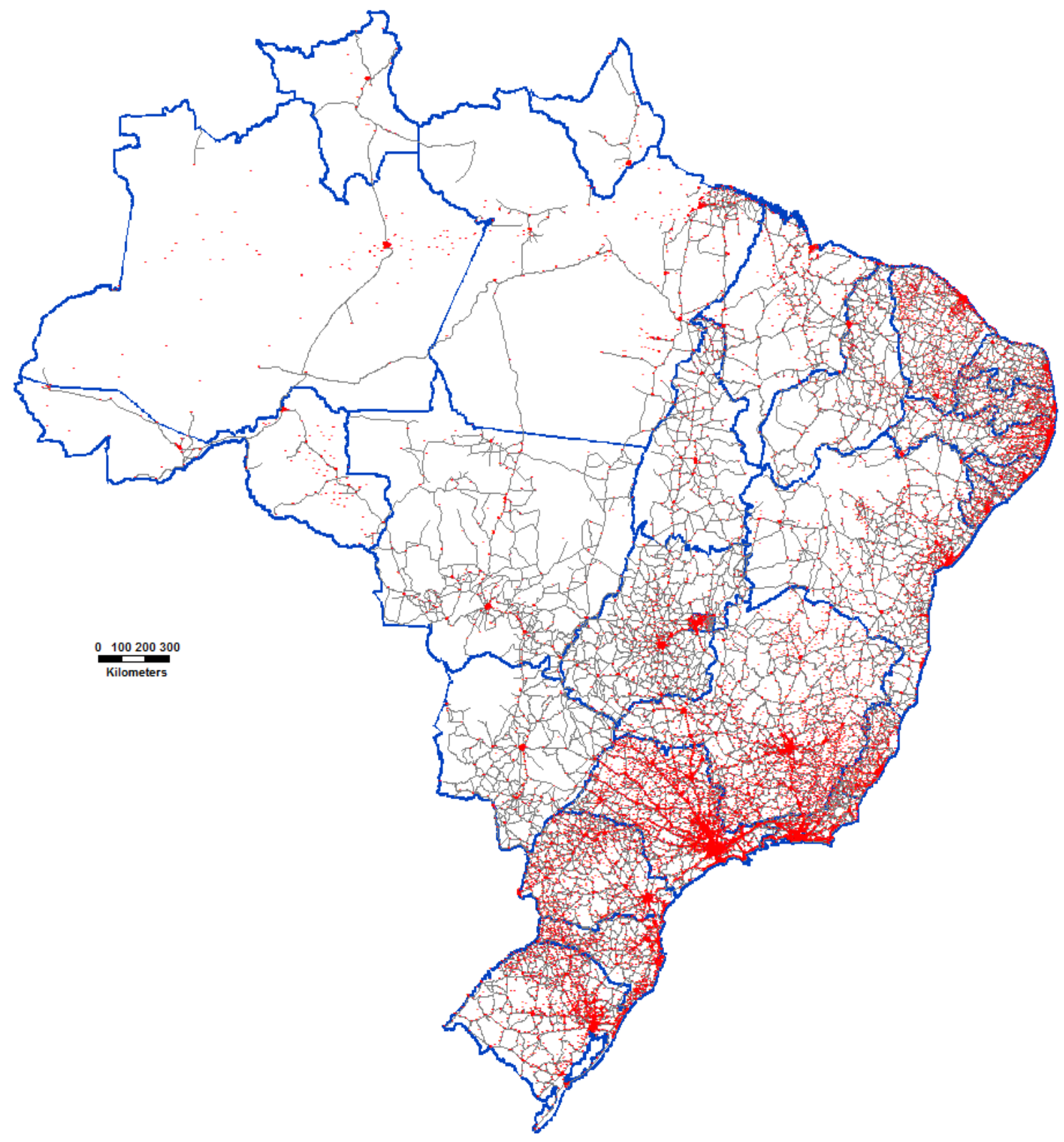

\section{Legenda}

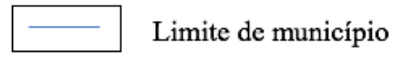

Limite da Unidade da Federação

$\longrightarrow$ Traçado das rodovias

- Estação Rádio Base (ERB)

Fonte: Anatel (2018b).

Organização: Mait Bertollo.

Elaboração: André Rodrigues Nagy. 
A distribuição das ERB pelo território brasileiro é basilar para o funcionamento das redes $2 \mathrm{G}, 3 \mathrm{G}$ e $4 \mathrm{G}$, e elas operam numa vasta área como uma rede integrada sem fios, permitindo a partilha ininterrupta da transmissão sem interferências quando os usuários se movem, mesmo em veículos motorizados. Essas redes usam o espectro licenciado e foram projetadas com tecnologia atualizada para redes sem fio, incluindo o serviço de voz. A principal característica dessa estrutura é oferecer cobertura onipresente e contínua, suportada por uma ERB que estende a conexão a vários quilômetros de distância. As estações estão interligadas por uma rede de backhaul, que também fornece interligação com a rede fixa.

Mapa 23 - Distribuição das ERB na região Centro-Oeste, 2018

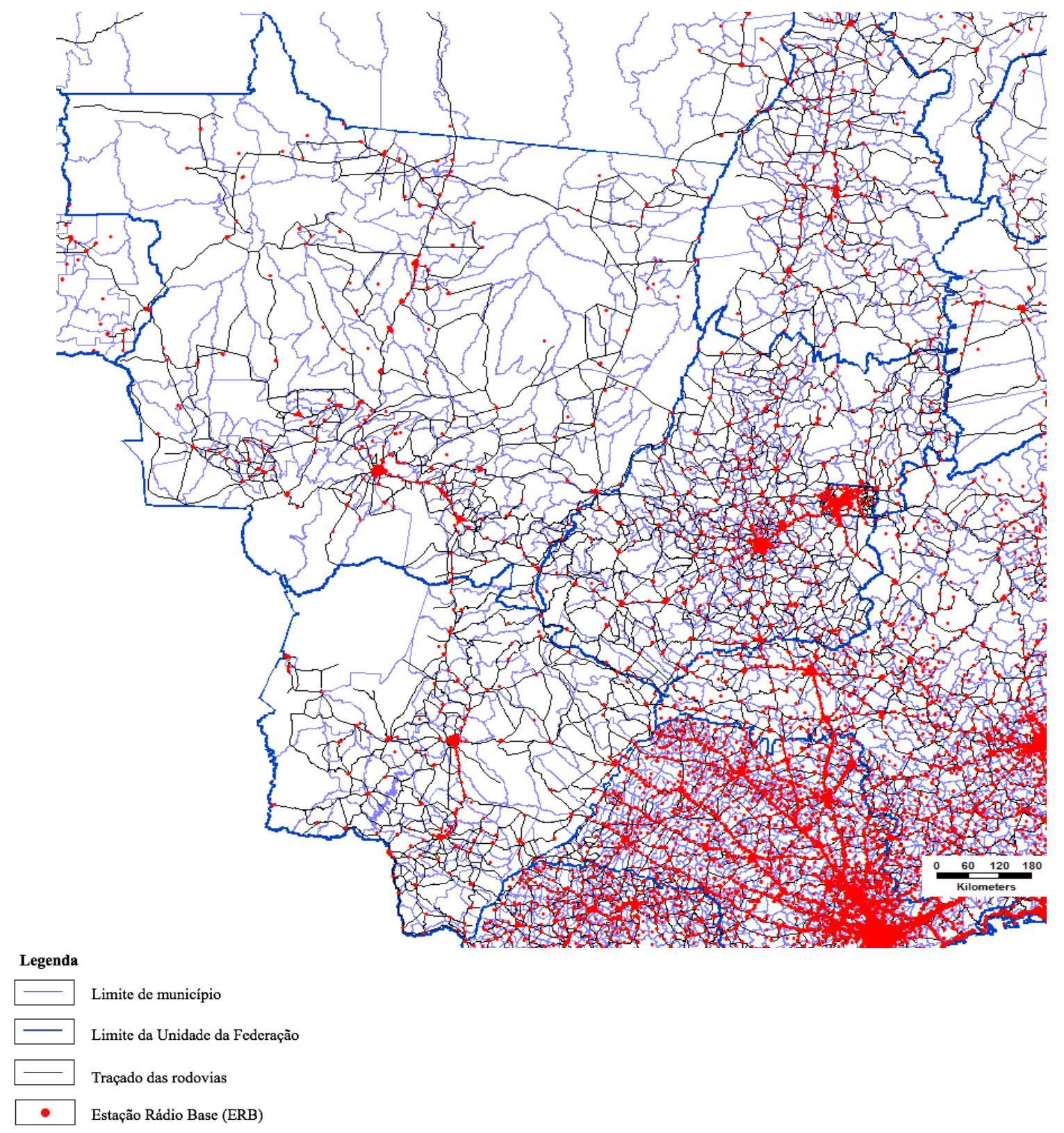

Fonte: Anatel (2018b).

Organização: Mait Bertollo.

Elaboração: André Rodrigues Nagy. 
Mapa 24 - Distribuição das ERB na região Norte, 2018

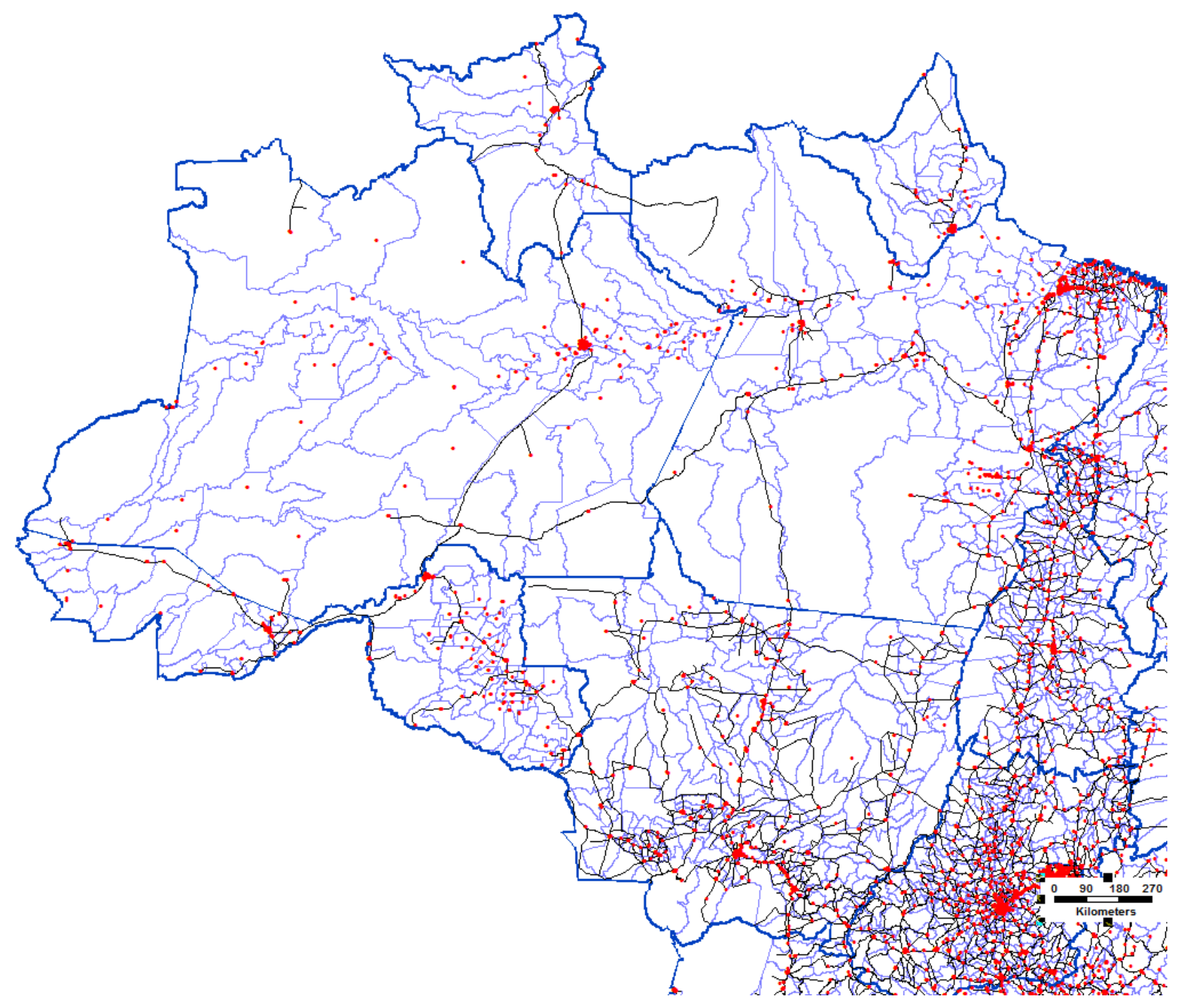

Legenda

$\square$ Limite de município

$\square$ Limite da Unidade da Federação

Traçado das rodovias

- Estação Rádio Base (ERB)

Fonte: Anatel (2018b).

Organização: Mait Bertollo.

Elaboração: André Rodrigues Nagy. 
Mapa 25 - Distribuição das ERB na região Nordeste, 2018
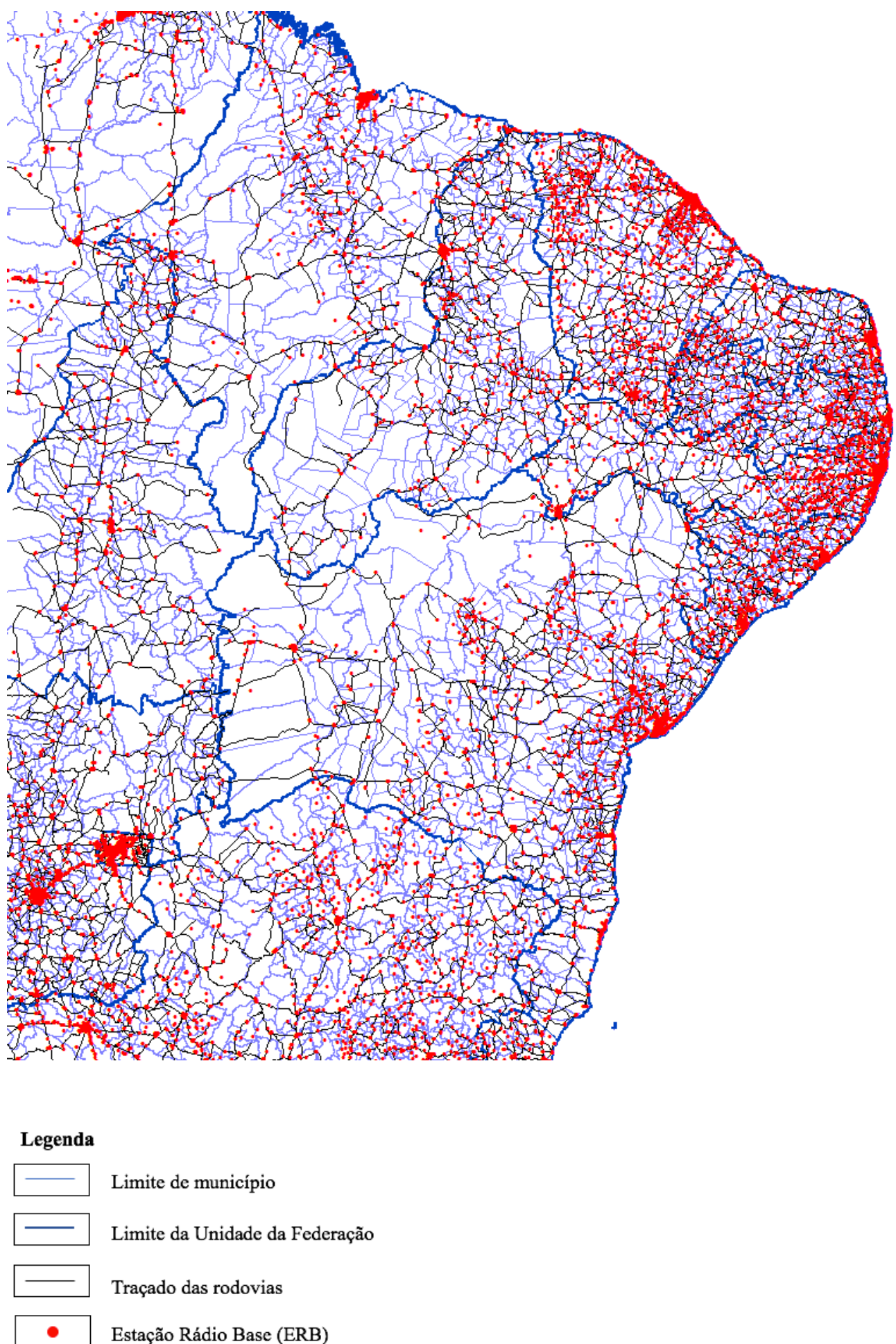

Fonte: Anatel (2018b).

Organização: Mait Bertollo.

Elaboração: André Rodrigues Nagy. 
Mapa 26 - Distribuição das ERB na região Sul, 2018

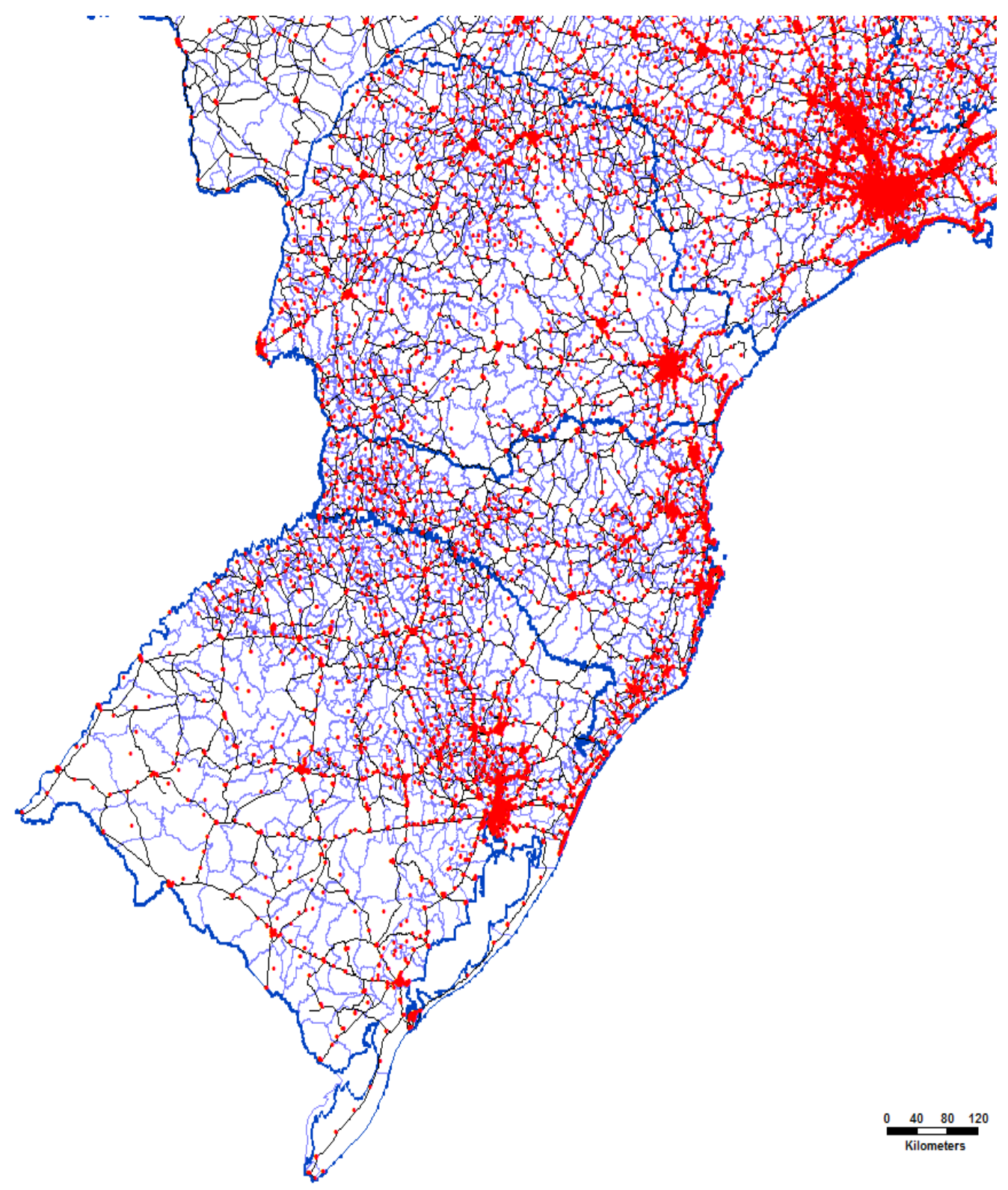

\section{Legenda}

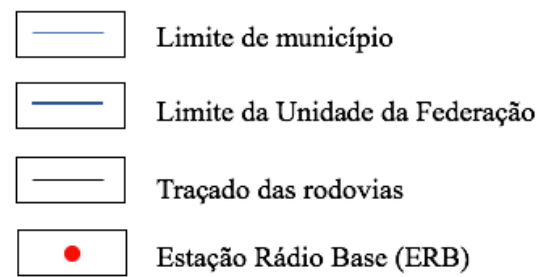

Fonte: Anatel (2018b).

Organização: Mait Bertollo.

Elaboração: André Rodrigues Nagy. 
Mapa 27 - Distribuição das ERB na região Sudeste, 2018
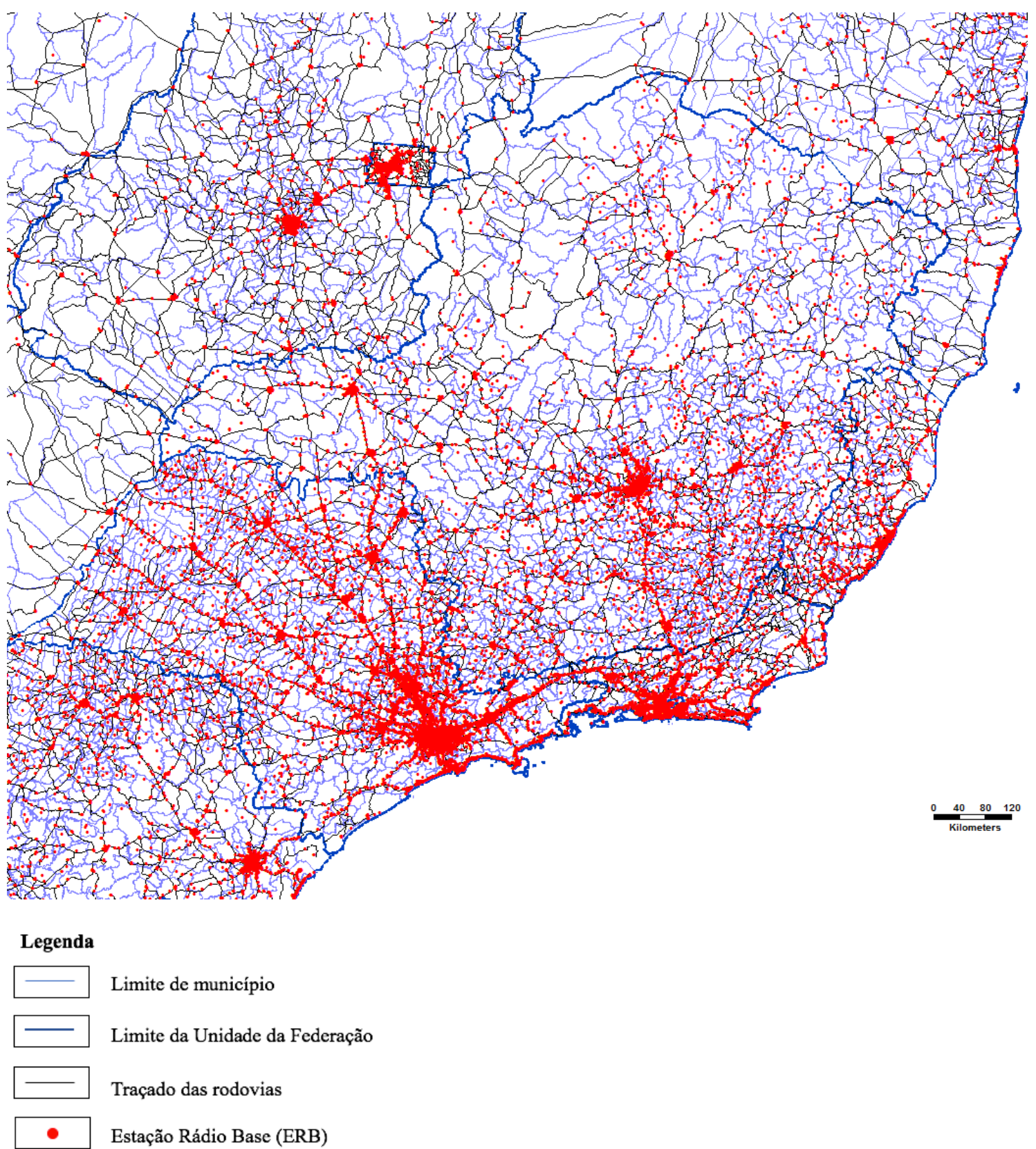

Fonte: Anatel (2018b).

Organização: Mait Bertollo.

Elaboração: André Rodrigues Nagy.

Verifica-se no Mapa 22 a disparidade da implementação dessa rede no território nacional, com a tradicional concentração no Sul e no Sudeste, ao longo do litoral nordestino e nas capitais, evidenciando a menor densidade de infraestruturas de comunicação na região Norte, ainda que haja pontos pulverizados pelo território. Assim, compreende-se a possibilidade de um novo funcionamento, uma nova organização e um novo uso do território a partir da emergência de novas tecnologias pela capilarização da informação por essa rede, baseada numa integração eletrônica corporativa de pontos selecionados (CASTILLO, 1999). 
A distribuição das ERB ao longo de rodovias é reflexo de especializações funcionais que definem os centros urbanos ligadas à capilarização da informação pelo território.

As manchas, linhas e pontos vermelhos que indicam ERB apresentam uma capilarização importante, e, dependendo da área onde é implantada, seu raio de cobertura pode variar de 100 metros a 150 quilômetros (MOBILE NETWORK GUIDE, 2018).

As ERB se distribuem em redes herdadas, conforme as condições topológicas, na expectativa de retorno dos investimentos nessa infraestrutura pelos serviços prestados. A configuração territorial, então, parte da totalidade material de um compartimento do espaço geográfico com o conjunto de técnicas arranjadas em sistema que forma a configuração territorial.

A distribuição das ERB coincide com a interligação da rede backbone de fibra ótica, que começa com a internet via Embratel, em 1999, interligando, por meio de conexão de 155 Mbps, os principais centros de roteamento como Rio de Janeiro, Belo Horizonte, Brasília, Salvador, Campinas, Curitiba, São Paulo, Florianópolis e Porto Alegre (Mapas 26 e 27).

Os investimentos nesse tipo de infraestrutura obedeceram a os interesses corporativos no processo de integração de redes para atender a demandas de variados serviços que têm agora como base sua organização na internet e na informação digital.

A distribuição e densidade das ERB segundo redes legadas e interesses corporativos para o uso do smartphone insere o indivíduo num circuito que envolve agentes hegemônicos como as operadoras de telecomunicação e o Estado, responsáveis por decisões sobre a localização e a regulação de torres e antenas, sem as quais é impossível conectar a internet.

Compreender a ação desses agentes e sua regulação sobre esse serviço é conhecer o poder de controlar o uso de determinados territórios, reconfigurando usos já existentes ou criando novos. Há uma estreita ligação entre as operadoras e o Estado e entre as decisões de localização e regulamentação. 
A ação da operadora sobre a localização de torres e antenas se dá com a escolha do lugar e do tipo de torre, que leva em conta a demanda, a área de cobertura desejada e as características do ambiente natural e construído, a exemplo do relevo, da vegetação, da densidade e do predomínio da horizontalização ou verticalização. A demanda é determinante para definir a quantidade de torres e antenas a ser ofertada a fim de garantir uma boa qualidade de serviço (STEINBERGER; TOFETI, 2015, p. 112).

São as características físicas que determinam a localização precisa das ERB, que se apoiam em torres de três modelos assentados diretamente no solo ou no topo de prédios, como as torres compactas de metal que ocupam uma área pequena em relação a sua altura (20 a 30 metros) e podem ser instaladas em ambientes urbanos densos para atingir um grande número de usuários. A torre de metal em treliça, com área maior e altura de 30 metros, é instalada em ambientes urbanos menos densos, zonas rurais ou próximas a rodovias, para atingir um pequeno número de usuários, e a treliça de metal roof top é instalada no topo de prédios dos centros urbanos, onde há grande demanda e pouca área disponível para assentar os modelos anteriores. A localização eficiente no espaço é essencial para o imbricado sistema técnico de telefonia celular, pois é a base de torres e antenas que dá suporte ao funcionamento satisfatório da conexão do smartphone.

Tanto quanto pelo aspecto técnico da localização das ERB, as empresas se interessam pelas frações do território com maior contingente populacional capaz de pagar pelos serviços de conexão: "para que as redes possam estender-se, é preciso uma primeira inversão em infraestrutura de comunicações, que para ser rentável requer mercados, os quais em geral se dão quando a rede já está criada" (SANCHEZ, 1991, p. 290).

A distribuição espacial das ERB nas unidades federativas e nos centros urbanos hierarquicamente mais importantes, medida por indicadores de teledensidade e de habitantes por torre/antena, permite constatar que o Norte é a região brasileira com a menor densidade informacional, reforçando, ao lado da raridade das demais redes técnicas, uma distribuição desigual e pouco acessível em dadas porções do território, em virtude do tamanho continental e da densidade populacional. Nas cidades, é evidente o importante papel dos sistemas técnicos na definição e caracterização da reestruturação urbana atual. 
O território nacional se desenha como uma combinação entre o que é deliberadamente concebido - grandes modernizações, implementação de sistemas técnicos -, promovendo novos usos dos recursos sociais e naturais que o compõem; e o que é recriado pelo conflito entre a necessidade da maioria, pois as refuncionalizações planejadas nunca atingem de modo pleno a dinâmica e a pluralidade dos anseios e necessidades da sociedade (ANTAS JR., 2011).

A rede móvel sempre exigiu uma organização de agentes nas escalas municipal, estadual, nacional e planetária para todos os objetos, principalmente no âmbito jurídico e técnico, com interações de formas diferentes nas escalas local até a mundial, e o smartphone é capaz de aglutinar esses eixos de modo interescalar.

\subsubsection{A rede wi-fi gratuita nas cidades}

$\mathrm{O}$ acesso à internet por smartphone é mais limitado quando consideramos a rede $w i-f i$ pública e gratuita instalada em municípios brasileiros, isto é, aquelas que não estão vinculadas a estabelecimentos privados. Essa estrutura permite a conexão à internet em locais públicos como praças, parques, estações de metrô, trem e ônibus, e a instalação desse sistema também teve influência do projeto Cidades Digitais, de âmbito federal, em 2013 (MINISTÉRIO DO PLANEJAMENTO, DESENVOLVIMENTO E GESTÃO, 2013), que visava instalar nos municípios infraestrutura para acesso gratuito aos habitantes em determinados pontos.

Atualmente, 26\% dos municípios brasileiros oferecem esse serviço, que nem sempre está disponível (IBGE, 2017), e sua abrangência segundo as unidades da federação está no Gráfico 17. 
Gráfico 17 - Municípios que oferecem rede wi-fi pública e gratuita no Brasil, por unidade da federação, 2017

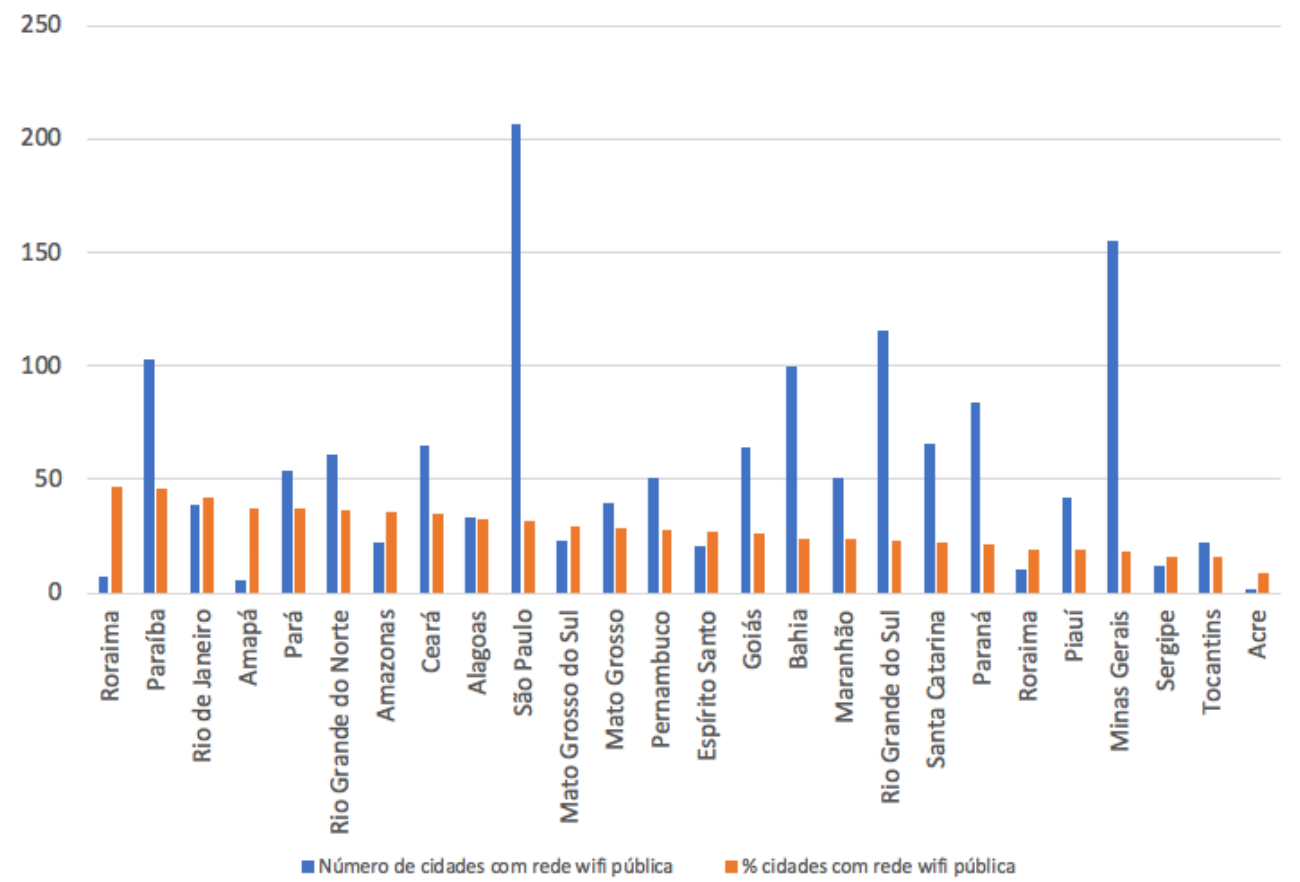

Fonte: IBGE (2015).

Elaboração: Mait Bertollo.

Sendo assim, usam-se outros meios de acesso à internet como as ERB por meio de operadoras, geralmente utilizando o aplicativo que funciona na lógica do zero rating.

\subsection{Capilarização da informação pelo smartphone e hierarquia e heterarquia urbanas}

Pelos dados sobre a capilarização do uso do smartphone em várias porções do território, a participação dos indivíduos nas redes técnicas significa que eles se relacionam, influenciam e são influenciados pela articulação das relações urbanas por intermédio do vetor informacional produzindo a contiguidade dessa rede.

A interação no território não é só vertical, de ordens dirigidas aos indivíduos partindo de empresas ou do Estado ou de interações entre agentes hegemônicos, o que caracteriza dinâmicas da hierarquia urbana tradicional. Essa interação se dá também entre agentes individuais, quando a informação banal altera o tipo de interação espacial e pode promover ou ser ela própria uma nova forma de influenciar comportamentos. 
Nesse contexto, o conceito de heterarquia urbana ajuda a entender as interações interescalares e a nova situação geográfica criada pelos smartphones, pois as resultantes espaciais nem sempre são necessariamente hierárquicas em toda a sua dimensão, "podendo ser também heterárquicas, com interações interdependentes em que existem outros nós, intervalos e redes na constituição e diferenciação das funções e papéis das cidades na rede urbana" (CATELAN, p. 80, 2013). Logo, intensifica-se a universalização de padrões técnicos e a ampliação de conteúdos e acessos à rede internet, justificando a aquisição de smartphones para a conexão.

As intersecções entre várias escalas combinam estruturas hierárquicas e heterárquicas por meio de ações verticais, horizontais ou transversais que se sucedem nas cidades e na rede urbana, articulando-as nos níveis local, regional, nacional e internacional.

As interações espaciais em várias escalas são orientadas por agentes hegemônicos, e a heterarquia pode ser entendida como outra relação além da hierárquica. A heterarquia não está em oposição à hierarquia da rede urbana, mas a complementa (DREIFUSS, 1996), dada a importância das cidades na rede urbana quanto aos fluxos informacionais e ao acesso à internet.

A intensificação das interações espaciais amplia e torna mais complexas as funções das cidades pequenas e médias, visto que as horizontalidades e verticalidades concretizam uma rede que tem interações nas escalas do lugar, da formação socioespacial e do mundo, para um conjunto de cidades em vários pontos conectados do território.

As cidades em rede podem estabelecer conexão com outras de mesma ou de diferentes hierarquias por meio das diferentes densidades, alcances e intensidades das redes serviço que permitem o acesso à internet.

As interações espaciais entre agentes que se articulam em mais de uma escala fornecem elementos para interpretar como o fluxo de informações na metrópole e em cidades menores ocorre de forma heterogênea e articula o local e o global.

Segundo Santos (1988, p. 12), “o espaço deve ser considerado como um conjunto indissociável de objetos geográficos, objetos naturais e objetos sociais e, de outro lado, a vida que os anima, ou aquilo que lhes dá vida, isto é, o movimento", e a complementaridade entre 
as várias escalas revela a articulação entre os agentes envolvidos atualmente na capilarização da informação.

Para que esse processo se concretize no território, é necessário que a contiguidade espacial (SPOSITO, 2005) se efetive por meio das redes e da "heterogeneização do papel e das funções das cidades na rede urbana, na interconexão de escalas geográficas e na ampliação da mobilidade do capital” (CATELAN, 2013, p. 137).

A heterarquia urbana permite entender as novas dinâmicas que estruturam a rede urbana atual no contexto das interações espaciais urbanas interescalares, em que "a informação, sobretudo a serviço das forças econômicas, hegemônicas e a serviço do Estado, é o grande regedor das ações que definem as novas realidades espaciais" (SANTOS, 2008, p. 193). Assim, a heterarquia ocorre quando o local e o regional estão articulados para a reprodução do capital, e, assim, as redes coexistem em múltiplas escalas.

As redes heterárquicas ocorrem entre as cidades sem que haja um comando ou uma dominação, quando os vetores globais não passam necessariamente pelas metrópoles (DOMENÈCH, 2002, p. 269). Assim, a rede de transmissão de informações cujo fluxo se capilariza por meio do smartphone chega a velocidades que podem ser medidas na ordem dos trilhões de bits por segundo, fluindo por rede de fibra ótica densa e global e por conexões por satélites e espectro eletromagnético e permite que a sociedade informacional desenvolva novas estruturas, relações, formas de produção, consumo e participação política (DREIFUSS, 1996). 


\title{
CAPÍTULO 4
}

\section{CAPILARIZAÇÃo DA INFORMAÇÃo E O ALCANCE DAS AÇÕES VERTICAIS}

\begin{abstract}
[...] as circunstâncias dos eventos jamais se repetem, pois são sempre novos, absolutos e irreversiveis, tendo em vista que estão sempre propondo uma nova história [...] essa presença absoluta funda a eficácia do evento. Onde ele se instala, há mudanças, pois, o evento é uma brutalidade eficaz.
\end{abstract}

Milton Santos, 2006

Ao tratar da rede urbana e das relações hierárquicas e heterárquicas de forma multiescalar, consideramos que escala é um instrumento conceitual para analisar o alcance das diferentes ações em vários planos como meio para dimensioná-las, posto que a totalidade está presente em todos os níveis, pois "a escala não fragmenta o real, apenas permite a sua apreensão" (CASTRO, 2000, p. 130).

As escalas são interconectadas e vão desde o corpo até o global, passando pelo lugar, pela cidade, pela região e pelo nacional (SMITH, 1992, 2004), e essa perspectiva permite estabelecer as conexões informacionais e a capilarização da informação pelo smartphone, na conexão pela rede suporte, que, por meio das várias redes de fibra ótica, antenas e espectro eletromagnético, se dão também desde o indivíduo e do plano local ao âmbito planetário.

Esses sistemas técnicos são propriedade de grandes corporações e por onde fluem ordens e informações que impactam cada ponto consubstanciado pelo smartphone como objeto pessoal. Segundo o Dicionário de Geografia Humana (JOHNSTON; GREGORY; SMITH, 1994), a escala é o nível de representação ou de resolução e, além de representar a relação entre a distância no mapa e a distância real, é uma ferramenta de análise do feixe de eventos que se materializa e atrita com as rugosidades presentes no espaço (SANTOS, 1996).

A escala também incorpora a dimensão temporal, posto que o tempo de ação dos agentes concretiza os eventos (SILVEIRA, M., 2004). As relações de poder no território são efetivadas, contestadas, negociadas e reguladas e resultam dos conflitos sociais por poder e controle; assim, a escala é ainda um campo de forças e uma dimensão socialmente construída (SWYNGEDOUW, 1997).

Assumindo a concepção do espaço geográfico como instância social, a escala é um limite e um conteúdo, que sempre se transforma por meio de dinâmicas que incidem sobre o acontecer regional ou local (SANTOS 1996). Ao investigar a relação entre evento e escala, é 
importante entender a "escala de origem" das variáveis do evento e sua "escala de realização" (SANTOS, 1996), onde se verifica o alcance do fenômeno.

A escala de origem varia segundo a força de seu emissor, como as informações que são enviadas ou acessadas pelo smartphone, e pode provocar uma reação encadeada no território, desde onde se emitem até onde chegam essas informações, assim como as informações banais trocadas entre usuários.

A escala de realização do fenômeno está ligada à extensão dos eventos, que entram em choque com as variáveis já existentes no lugar ou na região; por exemplo, a implantação de ERB para acesso ao sinal $3 \mathrm{G}$ simultânea à banalização do uso do smartphone em regiões onde, num passado recente, as fontes de informação eram prioritariamente a televisão analógica com canais abertos, o telefone fixo e, em menor volume, a internet discada.

Nesse contexto, as transformações relativas ao tipo de uso desse dispositivo se relacionam com as desigualdades sociais e a baixa escolaridade, a habilidade de lidar com informações textuais e imagéticas interativas, considerando que as informações recebidas geralmente procuram manipular os usuários e seu comportamento. De certo modo, pode-se afirmar que, de um momento para outro, muitos desses usuários passam a ter contato com a “cognoscibilidade planetária” (SANTOS, 1994) sem estar preparados para lidar com esse novo dado do período, cujas consequências são difíceis antever.

A força e a abrangência desproporcional dos agentes resultam no chamado "salto de escala" (SMITH, 2004), que se verifica quando a capacidade de determinado agente transcende sua escala de origem. A informação que é gerada ou modulada e enviada através das redes serviço globais oligopolizadas, conseguem transpor escalas por meio dos sistemas técnicos de que dispõem e por onde flui a maior parte das informações do planeta. Essas redes globais estão presentes em grande parte do território brasileiro, o que permite capilarizar informações para fins econômicos, políticos, de vigilância etc.

A escala pressupõe o território e o espaço geográfico, mas não a ideia de ciberespaço, que é indissociavelmente vinculado às relações sociais de produção e ao espaço, seja no âmbito das redes serviço ou no da rede suporte. 


\subsection{Direito ao acesso à tecnologia e à comunicação: os desconectados da rede}

A negação de acesso a serviços de comunicação descumpre o direito do cidadão, e a regulação das redes define o acesso ou não de determinados pontos, cidades, regiões e usuários. O comando da cobertura das redes e sua difusão afetam os processos produtivos e sociais, e "estar desconectado ou superficialmente conectado com a internet equivale a estar à margem do sistema global, interconectado. Desenvolvimento sem a internet seria o equivalente a industrialização sem eletricidade na Era Industrial" (CASTELLS, 2003, p. 220).

Procurando resolver a desconexão de várias porções do território, governos de vários países, inclusive o do Brasil, lançaram Planos Nacionais de Banda Larga (PNBL), com investimento e mecanismos para incentivar a migração para redes mais atualizadas e eficientes (CADERNOS TEMÁTICOS DO OBSERVATÓRIO SOFTEX, 2013). Para implementá-las, o plano considera a existência de redes legadas, a densidade populacional, as condições topológicas e a extensão territorial.

O PNBL no Brasil se deve à crescente demanda por acesso à internet com melhor conexão. Em grande medida como consequência da política de privatizações da década de 1990, as porções do território com menor densidade de infraestrutura para acesso à internet não receberam investimentos das empresas da iniciativa privada, pois, tendo população de baixa renda e/ou menor densidade populacional, não dariam retorno de capital suficiente para os padrões de acumulação do período. Como a implantação de redes de telecomunicação para transmissão de informação e para comunicação demanda operações complexas e custosas, as empresas escolheram investir em lugares capazes de lhes retornar em curto prazo o capital aplicado (CASTILLO, 1999).

A necessidade de um plano nacional de banda larga acentua a importância da presença do Estado e dos governos como reguladores das definições de prioridades e do direito ao acesso à informação e à comunicação. A conexão por banda larga ainda é muito cara no país, e, uma vez que empresas privadas não investem em certas regiões, o Estado deve fomentar esse desenvolvimento.

$\mathrm{O}$ acesso à informação e à comunicação e a inclusão da população no uso das tecnologias remete à Declaração Universal dos Direitos Humanos de 1948 (GONÇALVES, 2011, p. 20), no âmbito da contestação às práticas excludentes como meio de se superarem as 
desigualdades e, para Lévy (2000, p. 237), “o excluído e desconectado não participa da densidade relacional e cognitiva das comunidades virtuais e da inteligência coletiva".

O acesso à internet, à informação e à comunicação como direito humano fundamental conecta e interliga práticas sociais, campos de conhecimento e direitos, intensificados e fortalecidos pelos objetos técnicos que são disponibilizados. Acessar informações e serviços públicos, compartilhar vivências on-line, produzir e difundir conhecimento e informações através da internet são aspectos da cidadania. Acesso e uso exigem algum domínio das formas jurídicas para saber como elas condicionam a esfera social por arranjos normativos (ordenamento, organização e sistemas combinados).

As disparidades no território brasileiro envolvem tanto o significativo crescimento do uso do smartphone como a desconexão da internet. Essa desconexão e o peso historicamente expressivo da televisão como meio primordial de obtenção de informação no território resulta na continuidade de sua influência. Ainda é muito grande o número de pessoas que se informam apenas pela televisão (Gráfico 18).

Gráfico 18 - Acesso a informações por televisão ou smartphone no Brasil, por região, 2016

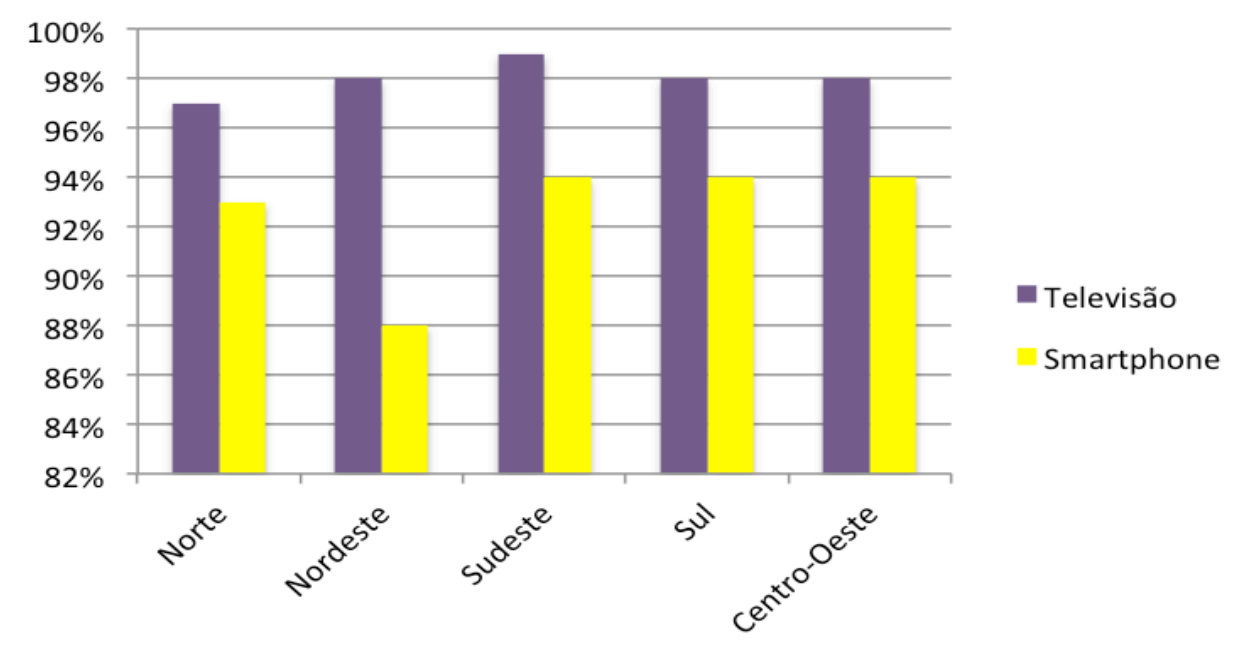

Fonte: Comitê Gestor da Internet (2016).

Elaboração: Mait Bertollo.

Em todas as regiões, o uso da televisão para se informar é relevante e indica o poder que tem até hoje esse sistema comunicacional que influencia e difunde ideologias, reproduzindo e transmitindo uma espécie de pensamento padrão sobre política, cultura, economia e comportamentos e que agora divide seu monopólio sobre a informação com as corporações das redes sociais. 
Para $46 \%$ dos entrevistados, o rádio é a principal fonte de informações e, para $42 \%$, a internet. Todos os analisados confirmam que as diferenças de renda e escolaridade são determinantes no uso e na apropriação da internet. A proporção de pessoas com renda familiar de até um salário-mínimo que acessam a internet pelo menos uma vez por semana era de $20 \%$, contra $76 \%$ entre as que têm renda superior a cinco salários-mínimos. Apenas 5\% dos que estudaram até o $5^{\circ}$ ano do ensino fundamental ${ }^{40}$ usa a internet, e a média de acesso era de três horas por dia. No grupo que tem formação superior, o percentual de uso é de $82 \%$, com tempo de conexão de seis horas por dia (COMITÊ GESTOR DA INTERNET, 2016).

Os recortes de renda mostram as disparidades no uso da rede, que seguem repetindo desigualdades históricas. A deficiência do acesso, o alto valor do serviço e do equipamento e a má qualidade da conexão são impedimentos para grande parcela da população que busca, no ambiente digital, uma possibilidade de se expressar, interagir ou se informar.

Gráfico 19 - Motivos da não utilização da internet

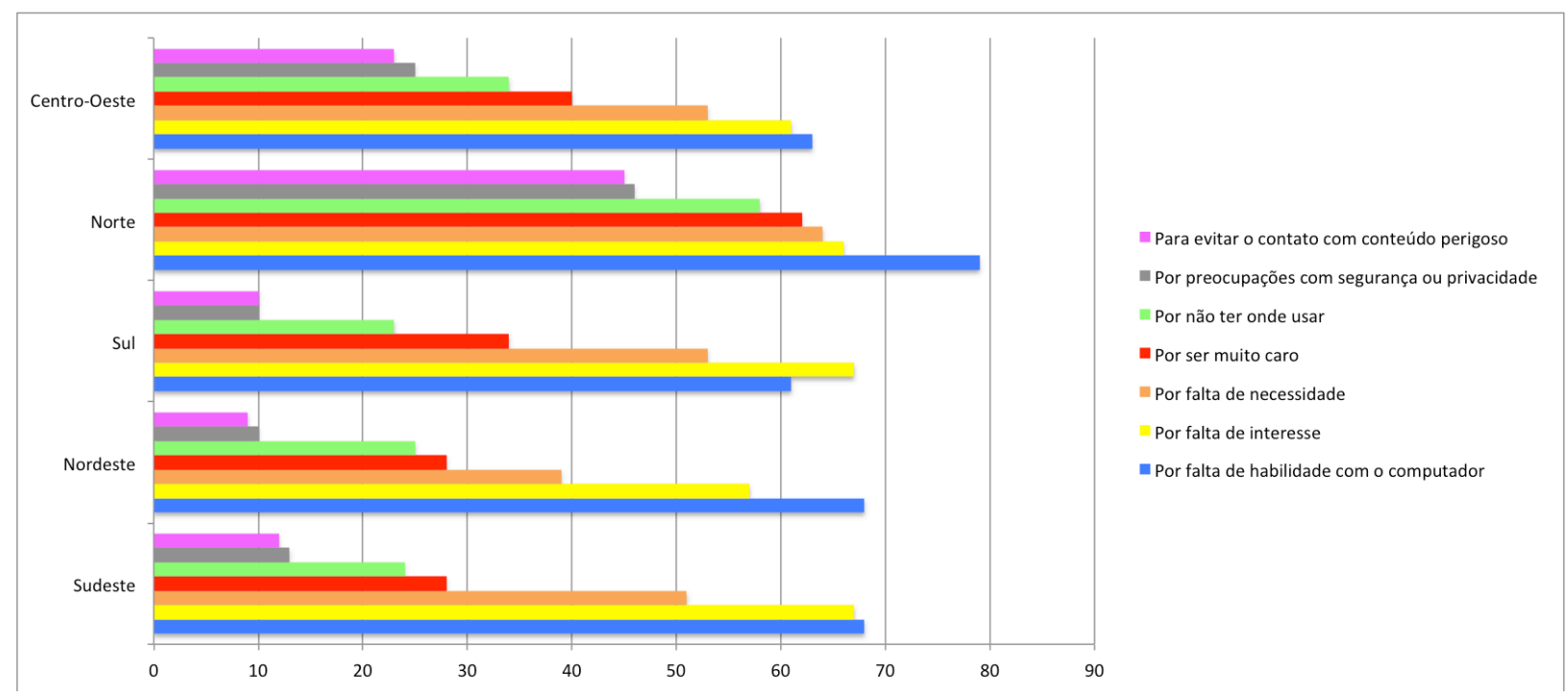

Fonte: Comitê Gestor da Internet (2016).

Elaboração: Mait Bertollo.

A desconexão da rede exclui o indivíduo do uso de novas técnicas e do desenvolvimento da capacidade comunicativa permitida pelas tecnologias de informação e comunicação; a chamada alfabetização digital surge como uma nova necessidade contemporânea. No Mapa 19, vemos que, em praticamente todas as regiões, a "falta de habilidade com o computador", que eventualmente resulta na "falta de interesse", são respectivamente o primeiro e o segundo motivo da desconexão, seguidos de "por ser muito

\footnotetext{
${ }^{40}$ Correspondente à antiga $4^{\mathrm{a}}$ série do $1^{\mathrm{o}}$ grau.
} 
caro" e "por não ter onde usar", e revelam o alto custo da conexão e do equipamento, que não é adequado à renda da maioria da população e a falta de infraestrutura para o uso dessa rede.

Gráfico 20 - Uso da internet no Brasil, por região, 2016

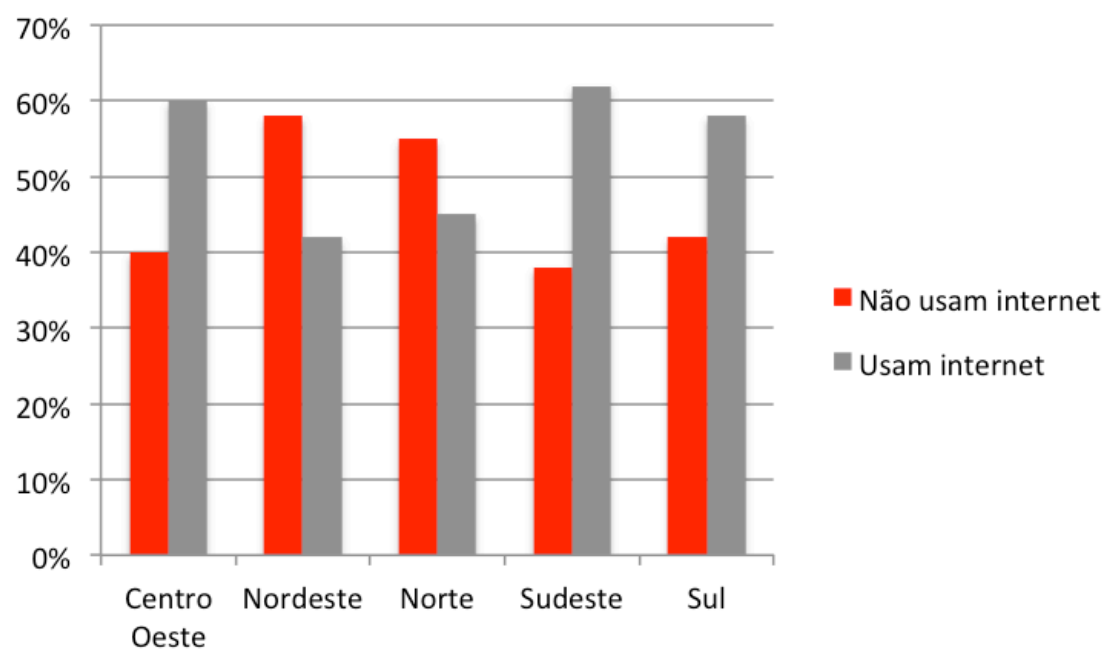

Fonte: Comitê Gestor da Internet (2016).

Elaboração: Mait Bertollo.

O Gráfico 20 confirma as disparidades regionais em relação ao uso de internet, em que Norte e Nordeste ainda têm a maioria da população sem acesso. A implementação de redes é relativa ao caráter político e integrador do território, pois elas:

[...] são capazes de criar condições sociais inéditas, de modificar a ordem econômica mundial, transformar os territórios solidarizar os elementos, mas ao mesmo tempo em que têm o potencial de solidarizar, de conectar, também têm o de excluir (DIAS, 1995a, p. 12).

Um em cada quatro brasileiros maiores de dez anos não possuía smartphone (IBGE, 2017), e o principal motivo alegado para isso foi seu custo. Ainda de acordo com o IBGE (2017), 41,1 milhões de pessoas não possuíam smartphone para uso pessoal em 2017, correspondendo a $23 \%$ da população com idade igual ou superior a 10 anos. Dessas pessoas, quase 23,4 milhões (60\%) tinham entre 10 e 17 anos ou 60 anos ou mais. Para 25,9\% das pessoas, o fator renda é relevante para possuir ou não o aparelho, e a falta de interesse foi apontada por $22 \%$. Cerca de $20 \%$ das pessoas usavam o smartphone de outros e $19,6 \%$ não sabiam usar um telefone móvel celular. Entre os que não possuíam o dispositivo, 11,8\% alegaram que o serviço de internet não estava disponível na região onde moravam. Os dados são mais visíveis no Gráfico 21. 
Gráfico 21 - Motivos pelos quais as pessoas não possuem smartphone, por percentual da população, Brasil, 2017

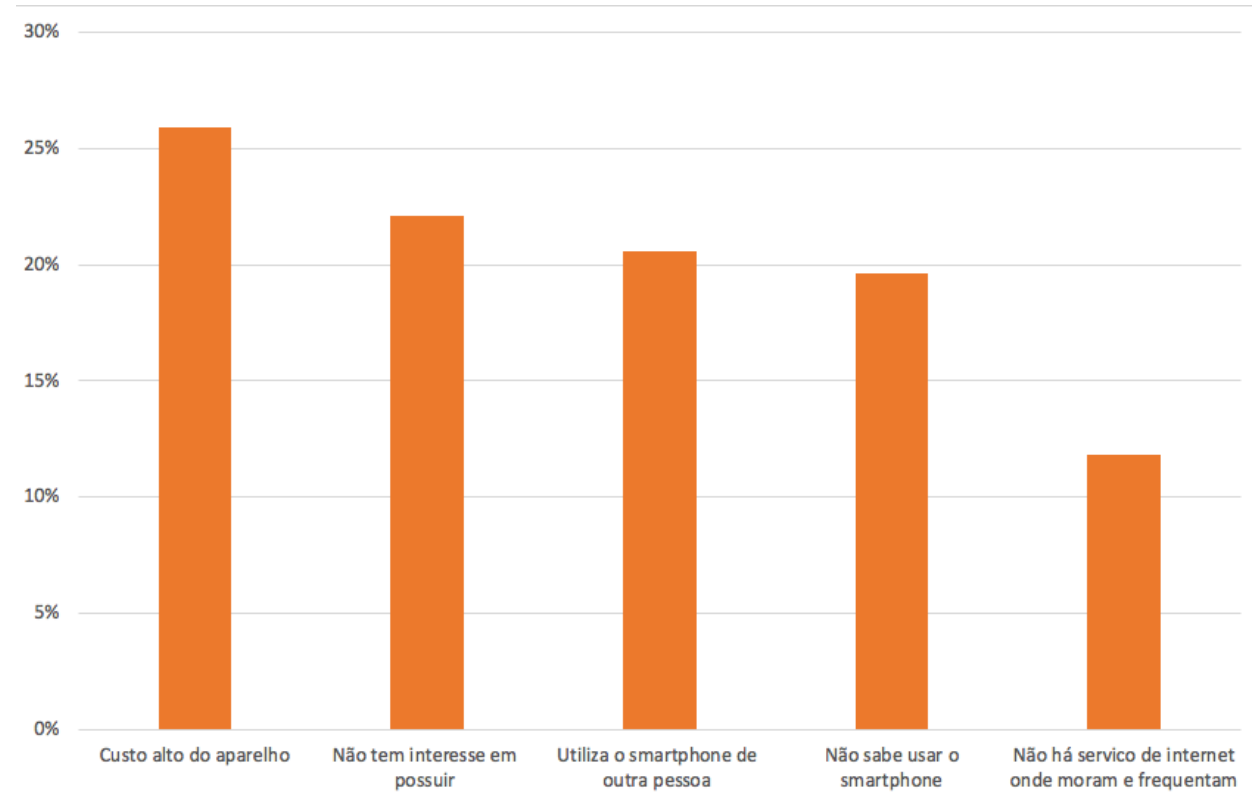

Fonte: IBGE (2016b).

Elaboração: Mait Bertollo.

Ainda que existam 220 milhões de smartphones ativos no Brasil (FGV, 2018), uma mesma pessoa pode possuir mais de um smartphone ou mais de um chip habilitado, sobretudo devida às promoções de operadoras, que oferecem ligações intraoperadora gratuitas.

Um fato importante ligado à desconexão das redes é o total desligamento dos canais de televisão aberta analógica em todos os municípios brasileiros, para desocupar a faixa de espectro de $700 \mathrm{Mhz}$ para ser utilizada pela rede 4G, o que acontecerá até o fim de 2018. Isso abrange 1,4 mil municípios e aproximadamente 150 milhões de pessoas (ANATEL, 2018b). Mas há milhares de municípios de pequeno porte onde as corporações de telecomunicação não investirão (pelo menos em curto prazo) após o desligamento da TV analógica para implantar a rede $4 \mathrm{G}$ no espectro livre.

Ao mesmo tempo, as emissoras de televisão, majoritariamente retransmissoras ou pertencentes a prefeituras, terão dificuldade para se digitalizar até 2022, como determina o cronograma oficial da Anatel. Acresce-se a isso a migração das rádios AM para FM (ANATEL, 2018a), encerrando a transmissão AM e promovendo um "apagão" do rádio em vários municípios isolados. Assim, sem rádio, sem televisão analógica e sem acesso à rede suporte que conecta a internet, a única solução, que é custosa e pouco estável, é a captação de sinal de televisão e internet por antena parabólica, o que tende a agravar as desigualdades no acesso à comunicação. 


\subsection{Capilarização dos serviços de internet por smartphone: bitcoin, blockchain e compartilhamento}

O bitcoin é uma espécie de moeda virtual ligada a mecanismos de tributação e controle dos meios de pagamentos e é alvo de uma série de debates sobre sua normatização para a garantia de privacidade e anonimato e contra o financiamento internacional de atos criminosos em nível mundial.

As inovações que permitiram o uso da bitcoin e do protocolo criptografado se fundamentam numa cadeia de blocos (blockchains) para "minerar criptomoedas"41 numa forma segura para ser transmitidas pela internet (PIRES, 2017). A criptomoeda, ou moeda virtual, é um meio de troca que funciona como moeda em alguns ambientes, embora não tenha status legal em nenhuma jurisdição. Sob certas circunstâncias, como em negócios realizados no mercado financeiro, ela pode ser convertida em moeda "tangível" ou funcionar como substituta de outras moedas (FICEN, 2014).

O blockchain é um sistema automatizado que estabelece garantias entre os indivíduos em todas as transações que envolvem um tipo de contrato na própria rede de computadores, a partir dos registros públicos que por ela se distribuem.

Os registros gerados são anônimos e não podem ser usados para controlar ou tentar influenciar comportamentos por meio de algoritmos, mas, como estão na rede, ficam gravados no sistema descentralizado de dispositivos por onde funcionam.

Nesse contexto, a confiança e a segurança são permitidas por meio da distribuição dos dados pela rede, como um "livro-caixa" descentralizado e criptografado. Os potenciais riscos do blockchain é que os agentes econômicos e políticos hegemônicos exerçam controle sobre a governança desse sistema descentralizado, definindo as regras regem sua legitimação.

Segundo Pires (2017), as dez maiores moedas virtuais mobilizaram no mercado de capitalização, em abril de 2017, o equivalente a US\$ 29 bilhões. A expansão e a concentração geográfica global de operações com moedas virtuais pode ser vista no Mapa 28, com a distribuição geográfica de 8.961 localidades com operações e serviços.

41 Mineração de criptomoedas é o processo com que se verificam, validam e adicionam à blockchain as transações com moedas digitais, por meio de um registro público composto por uma rede de usuários. 
Mapa 28 - Concentração geográfica das operações com moedas virtuais, 2018

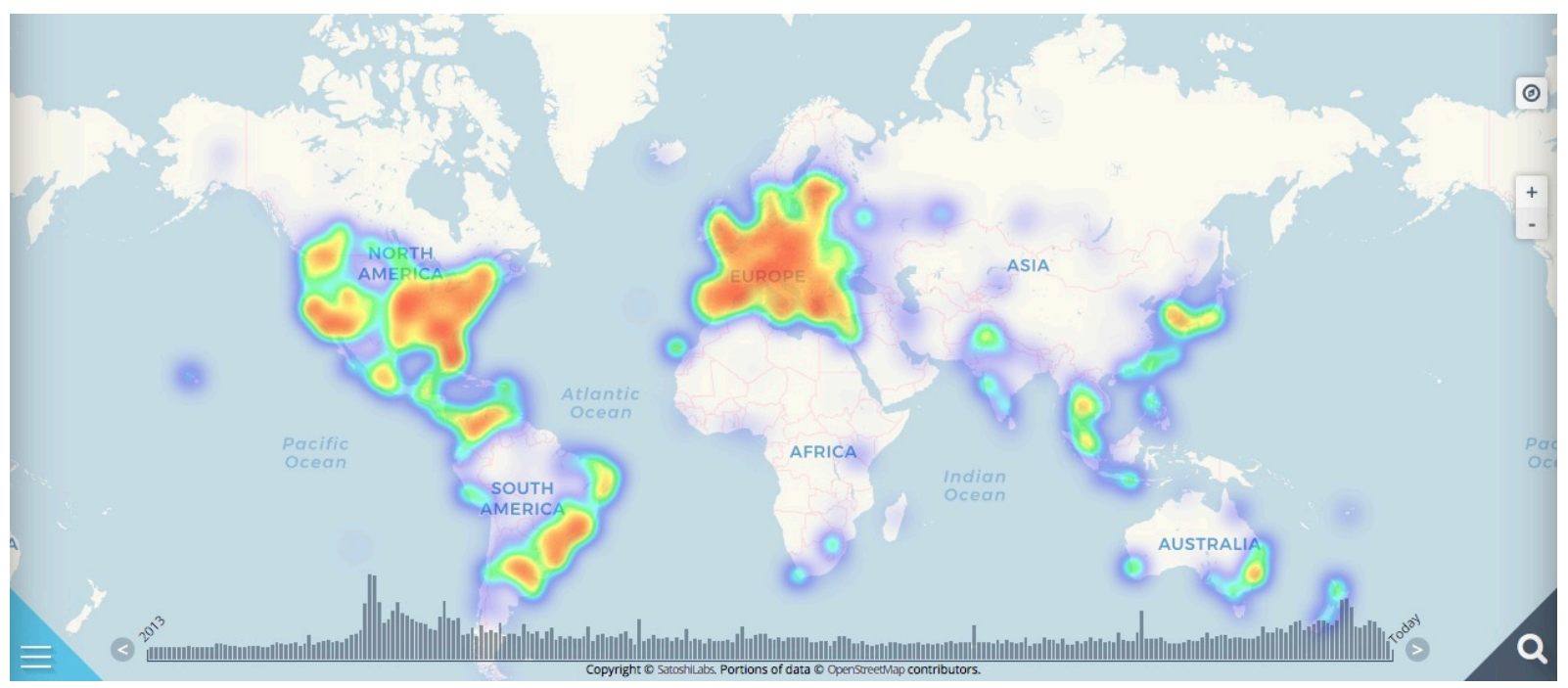

Fonte: Coinmap (2018).

No período atual, a circulação e os fluxos de moedas virtuais dão outras possibilidades de hierarquia, e, com a capilarização dos serviços de internet por smartphone, o uso das moedas virtuais pode ser banalizado, dando mais fluidez aos serviços e aos capitais globalizados, desde que exista uma complexa infraestrutura de rede suporte e rede serviço, aliadas à rede de energia elétrica, visto que essas operações demandam um grande volume de energia para processar dados das diferentes formas de criptomoeda.

A banalização do uso do smartphone como computador pessoal permitiu que esses dispositivos usassem e manipulassem big data, que é a reunião das informações sobre o que fazem os indivíduos e as empresas e que formas convencionais de análise de dados jamais permitiriam manipular. Esses dados alimentam a capacidade preditiva dos sistemas que os acessam, analisam e controlam, interferindo em comportamentos e preferências das pessoas, fazendo disso uma fonte de lucro e de poder sem precedentes. Essa capacidade analítica não está nos indivíduos, mas concentrada em poucas de corporações e Estados.

Nesse contexto, também foi concebida a "economia colaborativa", para que as pessoas possam compartilhar bens como automóveis ou sua própria habitação. Esse fenômeno se converteu num negócio de corporações hegemônicas que deu lugar a um sistema distribuído de caronas pelo Uber e ao compartilhamento de quartos ou casas, mediado pela empresa Airbnb (ABRAMOVAY, 2017).

Outro exemplo de economia de compartilhamento é o aplicativo Blablacar, pelo qual se pode pegar carona pagando o valor da viagem informado no aplicativo, que está em 
operação no Brasil desde 2006. Cada rota é uma combinação diferente entre os municípios de partida e de chegada, gerada dentro do aplicativo por pessoas que querem oferecer carona em suas viagens de automóvel. Como a relação entre o preço da gasolina e a renda média da população é uma das mais altas do mundo, há possibilidade de aumento de serviços como esse para se reduzirem custos.

Desde o lançamento da plataforma, o número de usuários ultrapassa três milhões (BLABLACAR, 2017), e, das 38 mil rotas cadastradas no aplicativo, cerca de 20 mil conectam cidades que não estão ligadas por transporte público. O Brasil é o país que lidera as viagens curtas, de 100 a 200 quilômetros. As principais rotas são entre as cidades de Campinas (SP), São Paulo (SP) e Rio de Janeiro (RJ), e são os trechos mais trafegados usando o aplicativo na América Latina. Há também opções para cruzar fronteiras nacionais, em cidades próximas do Uruguai, da Argentina e da Colômbia.

Esses instrumentos são um apanhado para dar uma dimensão e proporção dessa esfera em que o capitalismo financeiro se adapta e se apropria dos elementos de inovação gerados pelas tecnologias de inteligência computacional, baseadas nos algoritmos da blockchain e bitcoin, cujas empresas de vários ramos, organizações políticas, civis e de ajuda humanitária (como United Way Worldwide e Save the Children) crescentemente utilizam dessas ferramentas para comercializar serviços e financiar ações.

\subsection{O smartphone e o condicionamento do cotidiano nas esferas de consumo e produção}

A emergência do novo não deriva apenas da ciência e da tecnologia, mas também de tarefas ordinárias da atividade econômica (POLANYI, 1958): hoje, as interações entre agentes econômicos, empresas, setor financeiro, centros de pesquisa e variadas esferas governamentais se expandem para o consumo e as redes sociais de relacionamentos. Assim, a rede de redes exige cada vez mais inovação e valoriza o conhecimento e sua produção, difusão e socialização pelas tecnologias da informação, que permitem um aprimoramento das tecnologias cognitivas e relacionais, com a criação contínua do novo.

As atividades em rede são respaldadas pela variedade e pela difusão de novos smartphones, lançados em muitos tipos e momentos do ano, cuja produção e o consumo fomentam o setor produtivo das telecomunicações. Algumas das maiores empresas multinacionais de telecomunicações como a Siemens, a Motorola, a Alcatel, a Nokia e a 
Huawei instalaram-se no país a partir do leilão das licenças de $3 \mathrm{G}$, em dezembro de 2007 . A partir daí, o volume de investimentos e a ampliação territorial para implementação das redes resultou no consumo de 258,1 milhões de smartphones em 2016 (TELECO, 2018a).

Gráfico 22 - Crescimento anual da produção de smartphones no Brasil, em milhões

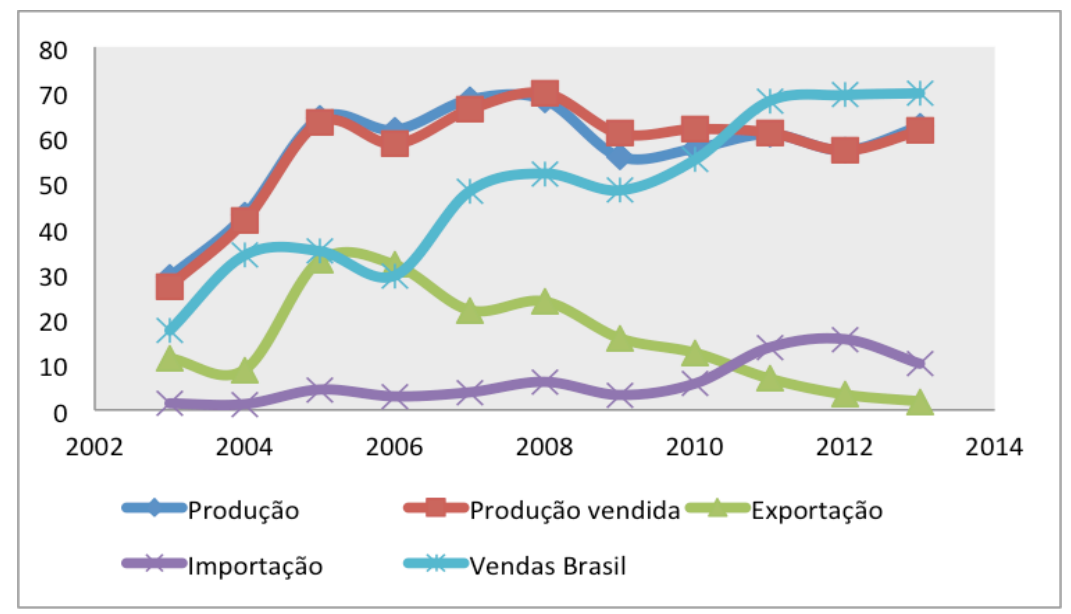

Fonte: Teleco (2016).

Elaboração: Mait Bertollo.

A produção e sobretudo a venda de smartphones no Brasil são crescentes no período, mostrando o interesse da população em estar conectada, associada à entrada de empresas produtoras no país.

As tecnologias da informação são um tipo de mercadoria estruturada por um sistema integrado de aparatos técnicos para servir a muitas e variadas atividades. O crescimento do consumo de serviços, tecnologias comunicacionais e informáticas e dos conteúdos informacionais, culturais e artísticos é diretamente associado à ferramenta de aquisição e produção de novos conhecimentos e informações, criados individualmente ou coletivamente por meio das redes. Portanto, as redes serviço, onde ocorre parte do funcionamento, são concebidas como espaço onde se supõe trabalho:

O espaço não é apenas material ou físico e está sempre ganhando novas definições substantivas com as mudanças históricas e que permite comunicar o resultado de um trabalho real, multidimensional. O espaço virtual se apoia no espaço real, ambos úteis à construção cotidiana da história, cuja aceleração autoriza, como é o caso do espaço virtual (SANTOS, 2000a, p. 12).

A produção, o consumo e a distribuição do smartphone pelo território, observados por meio da rede suporte, dão uma perspectiva do meio técnico-científico-informacional presente no território pelo número de usuários. 


\subsection{Reconhecimento de usuários e a influência dos algoritmos em seu comportamento}

Usando informações e dados pessoais, os algoritmos podem qualificar tipos de personalidade, ou personas, no jargão do marketing digital. Cada persona é uma representação fictícia de um consumidor ideal para determinado negócio, baseada em dados reais sobre o comportamento e características pessoais de cada usuário, o que permite criar estratégias para captar atenção, vender produtos, influenciar condutas etc. e nortear estratégias de criação de conteúdo.

A Google faz classificações por meio de algoritmos determinísticos, probabilísticos e prescritivos, o que lhe permite compor milhares de personas diferentes com dados que qualificam e manipulam comportamentos pelo uso de aplicativos (GOOGLE, 2018). Esse serviço pode ser usado pela própria Google ou vendido para outras empresas, como portais de notícias, por exemplo, caso no qual os algoritmos adaptam essas informações de modo a atingirem mais visibilidade.

As técnicas aplicadas decidem que informações, músicas ou textos são oferecidos a cada usuário para "melhorar sua experiência" de uso dos dispositivos, classificando e ranqueando as ações de cada indivíduo na rede e daí extraindo dados que impõem visões de mundo e intenções com base em discriminação e classificação, ainda que sejam apresentados como técnicas neutras, que só fazem cálculos exatos e imparciais (SILVEIRA, S., 2017b).

Os usuários acabam por moldar suas práticas segundo as ordens dos algoritmos e, ao mesmo tempo, o comportamento de cada indivíduo também altera os algoritmos. Essa cadeia de humanos e não humanos que perfaz a capilarização da informação tem no algoritmo um agente que, deliberadamente, configura os meios de interação, como a maior ou menor visualização de conteúdo por redes sociais como o Facebook, onde a visualização ampliada do conteúdo é cobrada, produzindo-se a qualificação de determinados públicos para cada tipo de informação.

O controle da visualização em plataformas como o Facebook mostra como os objetos técnicos se tornam cada vez mais opacos, verdadeiras "caixas-pretas" (LATOUR, 2001). Entre elas, destacamos a chamada machine learning, ${ }^{42}$ cujos algoritmos são descentralizados em vários tipos de dispositivos e plataformas, e é difícil acessar e entendê-las.

\footnotetext{
${ }^{42}$ Machine learning significa o mecanismo de aprendizado de uma máquina, isto é, um sistema que modifica seu
} 
Assim, os dados pessoais são a matéria prima da internet e da moeda no âmbito das redes serviço, das plataformas das redes sociais e das corporações de mídia na internet, que reconhecem os usuários e manipulam seu comportamento futuro subordinando-os às próprias corporações.

A inteligência artificial (IA) ${ }^{43}$ é a ferramenta que permite monitorar e controlar os usuários de internet, possibilitando a consolidação do poder de agentes hegemônicos com pouca ou nenhuma prática democrática, prestando-se à vigilância e a novas formas de manipulação e controle, com novos tipos de participação do usuário da internet visando uma maior produtividade ao processar os dados com tamanha eficiência.

A aparência de livre escolha dissimula a manipulação do comportamento de usuários e eleitores -, uma vez que qualquer agente com tal habilidade tecnológica, em qualquer lugar do planeta, pode, em escala global, influenciar a conduta de um grande número de pessoas.

Os exércitos de robôs ${ }^{44}$ que reconhecem e sabem acessar as especificidades de cada indivíduo, consolidando as ordens de agentes hegemônicos sobretudo humanos, impelem a comprar, votar, apoiar, gostar ou odiar, causando um certo "apocalipse banal" (HARARI, 2018) por meio de likes, cliques e compartilhamentos.

A IA permite processar grandes quantidades de informação e torna os sistemas centralizados mais eficientes do que os sistemas difusos, pois o aprendizado da máquina funciona melhor quando ela agrega mais informações para analisar, aprimorando os algoritmos (HARARI, 2018). Se a ordem for de milhões ou bilhões de pessoas, qualquer agente ou governo pode usar informações pessoais como dados médicos e de personalidade. E a crescente eficiência dos algoritmos confere autoridade aos dispositivos, na medida em que um indivíduo pode aprender, pela experiência, a confiar em algoritmos num grau tal que suas decisões serão parciais ou totalmente influenciadas por técnicas algorítmicas.

funcionamento autonomamente, tendo como base a própria "experiência da máquina", estabelecendo lógicas que visam melhorar o desempenho de uma tarefa ou tomar a decisão mais apropriada em dado contexto. Essas regras são determinadas com base no reconhecimento de padrões dos dados analisados. Por exemplo, se um usuário busca a palavra FORTE num site de busca, essa técnica analisa uma série de parâmetros para decidir se exibe resultados equivalentes a GENIOSO ou a INTENSO, dois sentidos admissíveis. Um dos vários parâmetros é o histórico de pesquisa do usuário: se já há alguma busca ligada à palavra INTENSO, o segundo significado é o mais aceitável.

43 Inteligência artificial (IA) é uma área da ciência da computação que cria dispositivos que simulam a capacidade humana de raciocinar, perceber, tomar decisões e resolver problemas por meio de algoritmos.

${ }^{44}$ Robô, ou bot, é uma técnica alimentada por informações filtradas e organizadas por algoritmos que permitem a interação de um usuário virtual em plataformas de redes sociais, por exemplo, podendo participar também de conversas com usuários reais. 
A competição para acumular dados é liderada por agentes hegemônicos como Google e Facebook e, na China, Baidu e Tencent, que operam como "comerciantes de atenção", capturando atenções ao fornecer informações, serviços e entretenimento para revender essa atenção a outras empresas. O principal negócio dessas corporações é a acumulação de grandes quantidades de dados pessoais dos indivíduos, que são seus verdadeiros produtos.

Os robôs têm um papel importante no uso dos dados e como influenciadores dos usuários das redes sociais, já que orientam discussões para certos temas, atacando adversários políticos e criando boatos, estimulando o "comportamento de manada" e criando uma noção falsa, diga-se - de uma maioria que defende determinado ponto de vista.

As empresas que criam os perfis falsos dos chamados robôs dão-lhes mais credibilidade usando fotos, nome e história pessoal. Alimentam discussões dando prosseguimento às narrativas criadas pelos controladores dos perfis e mesclando publicações sobre sua rotina com postagens apoiando políticos (HARARI, 2018).

\subsection{Capilarização da informação pelo aplicativo WhatsApp em smartphones}

O WhatsApp é um software e não precisa ser instalado para ser usado por meio de uma página web. Funciona tanto em computadores quanto em smartphones, onde é possível enviar e receber mensagens instantâneas de texto, imagens, vídeos, documentos e links, além de ser usado para chamadas de voz ou vídeo por meio da conexão com a internet. Também há a opção de enviar a localização do usuário, para que se compartilhe via mensagem o ponto exato no mapa, que vai sendo atualizado conforme o movimento do smartphone, por meio de seu GPS. E essas funções são compatíveis com os sistemas Android, BlackBerry OS, iOS, Symbian, Windows Phone e Nokia.

A empresa WhatsApp foi fundada em 2009 por ex-funcionários da empresa Yahoo na Califórnia, EUA, e seu uso popularizado foi reconhecido em 2012, quando foram trocados aproximadamente dois bilhões de mensagens por dia em abril e, num salto, para dez bilhões em agosto do mesmo ano (WHATSAPP, 2018). Por seu poder de se capilarizar e pelo crescente número de usuários, em 2014, a Facebook adquiriu a empresa por US\$ 16 bilhões e, em 2016, o aplicativo se tornou gratuito, alcançando um bilhão de usuários. Segundo a última atualização, o pico de mensagens trocadas por WhatsApp foi de 75 bilhões, em 31 de dezembro de 2017 (WHATSAPP, 2018). 
Observando seu uso no Brasil (Gráfico 13, Capítulo 3), verificamos que o aplicativo WhatsApp é um dos principais acessos quando há conexão ou atividades na internet.

Em todas as faixas de renda, nota-se a força desse aplicativos nas relações comunicacionais, substituindo cada vez mais os dados de voz e se banalizando no cotidiano dos indivíduos e no coletivo.

Segundo o IBGE (2017), 85\% das pessoas conectadas usavam o WhatsApp como meio de comunicação, perfazendo 120 milhões de usuários. O Brasil é o segundo país do mundo mais conectado a esse aplicativo, ficando atrás apenas das Filipinas.

A possibilidade de acessar o WhatsApp em vários pontos do território, ainda que a internet não funcione muito bem, se deve a questões políticas e técnicas. Daí ele ser o mais efetivo na troca de informações no território nacional.

A partir da política de zero rating, o WhatsApp é incluído em planos pré e pós-pagos por todas as operadoras brasileiras, além de ter uma vantagem estratégica perante os outros aplicativos de comunicação.

Assim, em face de um serviço de conexão caro para a renda média dos usuários, esse aplicativo é "gratuito", pois não se descontam os dados da franquia do usuário. Tecnicamente, as funções do WhatsApp podem ser ativadas mesmo que o sinal da internet não seja eficiente, e é possível trocar mensagens quando o sinal está na função EDGE, ou seja, em 2,5G. Por isso ele é muito usado por todos os estratos sociais e em várias porções do território brasileiro.

O tipo de uso desse aplicativo também é condicionado pelo grau de escolaridade da população brasileira. Segundo o IBGE (2018b), 38 milhões de pessoas entre os 15 e os 64 anos (30\% do total) são consideradas analfabetas funcionais. Isso significa que esse grupo tem dificuldade de entender e se expressar por meio de letras e números, por exemplo, de fazer cálculos simples ou identificar informações elementares em cartazes. São analfabetos absolutos 7\% dos habitantes, isto é, 11,5 milhões de pessoas acima de 15 anos que não sabem ler ou escrever.

Aqueles que são plenamente capazes de se comunicar pela linguagem escrita perfazem $12 \%$ da população, que é considerada de nível proficiente; entre os que concluíram o ensino médio, 13\% são analfabetos funcionais e, dos que têm ensino superior, 4\% (INAF, 2018). 
86\% dos analfabetos funcionais são usuários frequentes do WhatsApp (IBGE, 2018b), e a adesão integral ao aplicativo se dá por ser uma plataforma gratuita que substituiu o SMS, que é cobrado pelas operadoras de telefonia celular. O WhatsApp é vulnerável à disseminação de notícias falsas, pois dificilmente quem as recebe toma o cuidado de verificar sua procedência ou sua veracidade por meio de leituras ou pesquisas paralelas, inclusive porque o acesso a outras fontes de informação é limitado.

\subsection{Eleições 2018 e smartphone: evento e objeto}

As eleições em outubro de 2018 se constituíram num evento muito afetado por contextos econômicos, políticos, técnicos e normativos. Um deles, abordado aqui, é a capilarização da informação pelo smartphone no território brasileiro. Esse aparelho e o aplicativo WhatsApp já estavam amplamente disseminados em todas as classes sociais, mas a magnitude dessa influência só foi reconhecida pelo desenvolvimento e pelo resultado das eleições.

O condicionamento de comportamentos decorrentes das informações falsas capilarizadas em todas as tipologias de cidades e mesmo no campo, é absolutamente diferente do que se vira em eleições passadas, ainda que a propagação das chamadas "fake news" não seja algo inédito. Esse fato é marcado por uma suposta "força de mudança" que ressignifica objetos, conteúdos e identidades, numa proporção e magnitude nunca antes vistas.

Os agentes que participam e controlam a disseminação de informações de modo amplo e com determinada duração agem de forma sistêmica, para que o funcionamento e o controle dos eventos sejam eficientes, pois, "o nível da organização depende da escala de sua regulação e da incidência sobre a área de ocorrência do evento” (SANTOS, 2006, p. 149).

Logo, a disseminação de notícias falsas nas eleições de 28 de outubro, que elegeram presidente, governadores, senadores e deputados estaduais e federais no Brasil, foi um evento que se concretizou de modo particularmente potente no objeto técnico smartphone e no território nacional. 
A mudança do objeto está ligada às diferentes relações que ele mantém com os diversos eventos (WHITEHEAD ${ }^{45}$ apud SANTOS, 2006, p. 118). Assim, a relação entre as eleições e o uso do smartphone (e, consequentemente, o do aplicativo WhatsApp) se deu por meio de ações sucessivas e concomitantes, e, em cada lugar, o tempo dessas diversas ações e dos diferentes agentes não é o mesmo.

A banalização do uso do WhatsApp permitiu capilarizar informações provenientes de vários agentes de diversas escalas, e os usuários que as acessam perfazem uma diversidade extensa de renda, origem e de localização.

A simultaneidade que esse objeto técnico promove na troca de informações pode ser entendida como o "tempo concreto" ou o "tempo da vida de todos", pois a capilarização das informações implica múltiplas possibilidades de uso do território e diferentes usos do tempo (SANTOS, 2004).

Logo, o que acontece sincronicamente em um lugar é também determinado pelo que acontece em outras escalas, local, regional, nacional ou global. Assim, associam-se o tempo interno (do lugar) e um tempo externo (do mundo) (SANTOS, 2004), numa lógica em que as diversas escalas envolvidas no evento se articulam em determinado recorte temporal.

Os eventos são portadores de ação no presente e não se repetem, porque suas circunstâncias nunca são as mesmas e, por isso, são irreversíveis. O evento das eleições aponta uma série de variáveis, de lógicas locais, regionais, nacionais e globais que se materializaram no espaço em função de um sistema de objetos e um sistema de ações imbuídos de intencionalidades.

Nas eleições de 2018, para atingir mais eleitores, as campanhas políticas utilizaram softwares capazes de coletar o número do telefone de milhões de brasileiros na rede social Facebook e criar grupos para o envio automático de mensagens em massa pelo WhatsApp.

Esse serviço custa cerca de R $\$ 1.000,00$ e é oferecido por empresas ou pode ser adquirido de forma ilegal, para evitar rastros em prestações de contas. Essa técnica foi usada em campanhas de candidatos à presidência e às casas legislativas, de modo que o WhatsApp

45 WHITEHEAD, A. N. An enquiry concerning the principles of natural knowledge. Cambridge, MA: Cambridge University Press, 1919. 
teve um papel significativo na campanha eleitoral, fosse para utilizar os dados, fosse para influenciar eleitores.

Os softwares para envio automático de mensagens usam dados de usuários que ficam públicos e são colhidos em redes sociais como o Facebook e as bases de dados são vendidas legalmente. Para fazer os chamados "disparos em massa", criam-se no WhatsApp grupos onde se adicionam usuários sem seu consentimento e, aqueles que não saem, são influenciados pelas informações enviadas pelos gerenciadores dos grupos.

É possível modular as informações e criar grupos específicos, de habitantes de determinado lugar ou divididos por gênero, classe social etc. Assim, as informações são mais direcionadas e, ao mesmo tempo, são conduzidas as opiniões por debatedores que estão no grupo para disseminar ideias.

A modulação de informações permite agrupar segmentos específicos de pessoas para enviar mensagens por meio das chamadas "fazendas de celulares", cuja estrutura, montada por empresas, dispõe de dezenas de aparelhos que se alternam nos envios para evitar os banimentos por spam, que neutralizam os chips utilizados, e já existem serviços que usam apenas os chips, sem a necessidade do smartphone.

Existem também ferramentas que bloqueiam a identificação da origem da chamada e, assim, numerosos grupos de WhatsApp foram criados por números com DDI dos EUA sem ser de lá, o que configura uma fraude. Dada a eclosão do mercado de marketing por redes sociais, o custo médio do envio de um milhão de mensagens de WhatsApp pode ser de $\mathrm{R} \$ 30$ mil ou mais, dependendo do que é acordado.

A dispersão de mensagens e a criação de grupos em massa descumprem a lei, pois influenciam as eleições de modo artificial e ferem as regras de privacidade dos dados das comunidades virtuais (SOUZA, C., 2018). Além disso, as plataformas de redes sociais, como o Facebook, têm regras que proíbem a instrumentalização dos dados para amplificar determinadas discussões.

Segundo o Facebook, as ferramentas mencionadas acima desobedecem as regras de não permissão de coleta automatizada de dados. No WhatsApp, cada usuário podia criar até 9.999 grupos, e, em agosto de 2018, o número de mensagens encaminhadas simultaneamente 
em conversas diferentes foi reduzido de 256 para 20, razão da disseminação massiva de notícias falsas, além do banimento de centenas de milhares de contas durante o período das eleições no Brasil. Cabe ressaltar que o Facebook também está sob investigação, em esfera internacional, pela venda de dados dos usuários de sua rede (CADWALLADR; GRAHAMHARRISON, 2018).

O Tribunal Superior Eleitoral não tem legislação eleitoral específica para o WhatsApp ou outras redes sociais, e o Marco Civil da internet trata de questões de conteúdo de terceiros, não de aplicativos (SOUZA, C., 2018). Nesses termos, as plataformas não são responsáveis pela informação que circula por elas automaticamente, sendo apenas obrigadas a remover determinados conteúdos.

A força desse evento se deveu às relações normativas no âmbito das redes sociais: as normas que as regem e o encaminhamento da produção de novas não deu conta do impacto desse novo tipo de uso. Acresce-se que a criação de leis é relativa aos resultados das contradições nas relações sociais, que atualmente são também mediadas pelas técnicas de comunicação e seus objetos, que se espalham em diversas interações espaciais.

Esses objetos técnicos condicionam as ações por meio de normas técnicas, organizacionais e políticas que emergem como "resultante de um condicionamento que produz a rotinização de um dado evento" (ANTAS JR., 2005, p. 59).

A definição das ações e das localidades a que se dirigem as informações condicionam atuações futuras, criando normas que "aperfeiçoam e completam o modo de usar os objetos" (SILVEIRA, M., 2002a, p. 211). A presença do smartphone em vários lugares modifica o valor das normas vigentes, de modo que as normas decorrentes de outras divisões do trabalho e, portanto, de outros períodos, ficam cedo ou tarde obsoletas e não logram regular os sistemas de engenharia funcionalizados por uma nova racionalidade hegemônica.

O WhatsApp preserva a privacidade de ponta a ponta de forma criptografada, e, assim, os conteúdos não estão nos servidores da plataforma, mas nos dispositivos dos usuários. Portanto, quem cria e gerencia grupos de WhatsApp está protegido para compartilhar conteúdo de forma privada, o que dificulta a investigação de notícias falsas; além disso, 90\% 
dos usuários fazem parte de pelo menos um grupo, o que facilita ainda mais a difusão de propaganda eleitoral (SOUZA, C., 2018).

Por meio da lógica do zero rating, os usuários se condicionam a usar apenas o aplicativo como fonte de informação, não navegando fora dele para conferir as informações que recebem por meio dele ou acessar outras. As consequências desse mecanismo que utiliza o WhatsApp para disseminar notícias falsas de forma simples para muitos tipos de usuário não suscitou uma discussão mais profunda sobre possíveis soluções para não afetar seu modelo normativo ou de negócios das corporações proprietárias de redes sociais. Agora, a propaganda eleitoral pela televisão divide seu monopólio com as redes sociais acessadas por smartphone.

Em função disso, empresários compraram irregularmente pacotes massivos de envio de mensagens com notícias falsas, ação proibida pela legislação eleitoral, segundo a qual só os próprios candidatos, partidos e suas coligações podem comprar propaganda eleitoral. Como se nota, este é um contexto que atinge a população mais vulnerável ao uso perverso da informação, sendo o smartphone o objeto técnico por excelência na promoção dessa ação, configurando o que SANTOS (2000b) definiu como violência da informação.

As empresas que compraram de companhias especializadas o serviço de "disparo em massa" de mensagens no WhatsApp usaram a base do próprio candidato, ou do partido, ou das próprias empresas que prestam o serviço, o que também é ilegal, porque a legislação eleitoral também não permite a compra de base de dados de terceiros. Essa prática pode configurar doação de campanha por empresa, o que é igualmente ilegal. Além dessas, pode haver outra irregularidade, se se comprovar que a compra partiu de uma campanha política e não foi registrada na prestação de contas do candidato.

Recentemente, o meio político vem se servindo das redes suporte e das redes serviço para influenciar comportamentos, usando dados e algoritmos por meio informações que os provedores acessam e coletam no dia a dia dos usuários como histórico de navegação na web e compartilhamento com terceiros, como anunciantes e empresas de marketing.

A conexão do smartphone à internet passa obrigatoriamente pela operadora, que, juntamente com os aplicativos utilizados, consegue localizar o usuário em qualquer ponto 
onde ele tenha conexão. Aplicativos como Google Maps, Gmail, WhatsApp, Facebook e outros acessam dados do georreferenciamento de cada ponto e de cada ação do usuário em suas plataformas: envios, curtidas e compartilhamentos.

As operadoras registram os deslocamentos do smartphone por meio das conexões às antenas e, cruzando esses dados, podem prever com pequena margem de erro onde o usuário poderá estar em determinado momento futuro.

Por meio das curtidas em redes sociais como o Facebook, os algoritmos podem inferir a orientação sexual, o grupo étnico, a orientação política e religiosa e gostos particulares dos usuários. Com cerca de 200 curtidas, o algoritmo já tem elementos para conhecer profundamente a personalidade do usuário (HILBERT, 2018).

As técnicas que detectam e preveem características pessoais são usadas por empresas de marketing ou de campanhas políticas por meio da big data. Desenvolver algoritmos de inteligência artificial demanda um grande investimento e pode ser aplicado com vários propósitos.

As características técnicas do aplicativo WhatsApp foram providenciais para a capilarização da informação por meio do smartphone. Sua pulverização e popularização em todos os estratos sociais é administrada por um escritório que fica no estado da Califórnia, nos EUA, e não há escritórios ou representantes no Brasil. Tampouco há servidores locais que armazenem os dados, patenteando a não regulação dos governos sobre essas empresas globais. Tratados de livre comércio assinados por governos de quase todos os países proíbem a exigência de que os dados sejam provisionados localmente, celebrando o "livre fluxo de dados, sem restrições de qualquer governo" (MOZOROV, 2018, p. 9).

Com o objetivo de sequestrar a atenção dos usuários, os dispositivos e suas aplicações são sustentados pela chamada "inteligência artificial”, que transforma a comunicação e coleta informações de todas as ações dos usuários. Muitas fontes de informação produzem propaganda política que arrebanha seguidores em vários pontos do território que, acreditando nela ou sem meios ou conhecimento para refutá-la, propagam-na por sua posição dentro de uma sociedade polarizada. Ademais, vem se disseminando um tipo específico de postura "política" conservadora que reage de forma passional às informações que recebe e, tendo sua 
capacidade de reflexão diminuída, não reconhece que pode estar agindo em função de notícias falsas.

Ao mesmo tempo, a televisão deixou de ter um papel determinante nas eleições e foi substituída por outros meios. O WhatsApp foi a rede mais utilizada por $70 \%$ dos eleitores, e a metade deles diz acreditar nas informações compartilhadas pelo aplicativo (DATAFOLHA, 2018).

Os usuários de vários planos de conexão podem usar o WhatsApp sem ônus no pacote de dados, mesmo quando terminam os dados de internet do celular. Quando isso acontece, o usuário só pode acessar esse aplicativo, mas não pode abrir links, fazer uma simples pesquisa na internet ou ler notícias em portais de jornalismo ou de outras fontes, por causa do recurso de zero rating.

O zero rating pode beneficiar os usuários de baixa renda por dar acesso gratuito à internet por meio de alguns aplicativos, mas restringe o acesso a todo o conteúdo disponível na internet.

Não há acesso aberto e livre a notícias quando se acessa um link pelo WhatsApp, pois ele é "clipado", isto é, não pode acessar a massa de dados nem entrar no site da empresa de mídia que publicou a notícia ou em outros.

Conectar-se à internet só por meio de aplicativos influi no recebimento e no entendimento das notícias, de que só se lê a manchete, ou seja, o link com o título, diferentemente de quando se entra em várias fontes de informação com o desenvolvimento das notícias.

Considerando o acesso dos brasileiros ao celular pelos dados da PNAD, as classes de renda mais baixas só podem entrar na internet por um smartphone, como acontece com $76 \%$ das pessoas das classes D e E.

Em 2017, a prática de zero rating atuava em 58 ofertas entre os pacotes comercializados pelas operadoras, sendo a maioria delas para o aplicativo WhatsApp (ANATEL, 2017b). Operadoras como Claro, Vivo e TIM oferecem WhatsApp sem descontá- 
lo do pacote de dados em planos pré ou pós-pagos, o que reduz a variedade de informações disponíveis ao usuário.

O acesso patrocinado por meio do zero rating é fruto de um acordo comercial entre as operadoras e os provedores de aplicações de internet, e os custos do tráfego são absorvidos por estes. Logo, na maior parte das vezes, são as próprias empresas donas dos aplicativos que pagam pelo acesso ilimitado para expandir sua influência e seu poder de divulgação de propaganda.

O zero rating também viola o Marco Civil da internet, lei que regula o uso da rede no Brasil, e fere a livre concorrência, já que privilegia alguns aplicativos. Dadas as condições econômicas da maioria da população, aqueles que não têm possibilidade de acessar livremente a internet acabam tendo seu direito à comunicação, no mínimo, limitado (GRAGNANI, 2018).

$68 \%$ dos eleitores tinha conta em alguma rede social, e, entre os mais jovens (93\%), os mais instruídos (94\%) e os mais ricos (92\%), esse índice é mais alto. O WhatsApp é a rede mais popular, presente na conta de $66 \%$ dos eleitores.

Quanto ao percentual de eleitores que utilizam o Whatsapp para se informar sobre as eleições, os Gráficos 23 e 24 permitem observar essa dimensão. 
Gráfico 23 - Percentual do uso do aplicativo WhatsApp, por eleitores dos candidatos à presidência

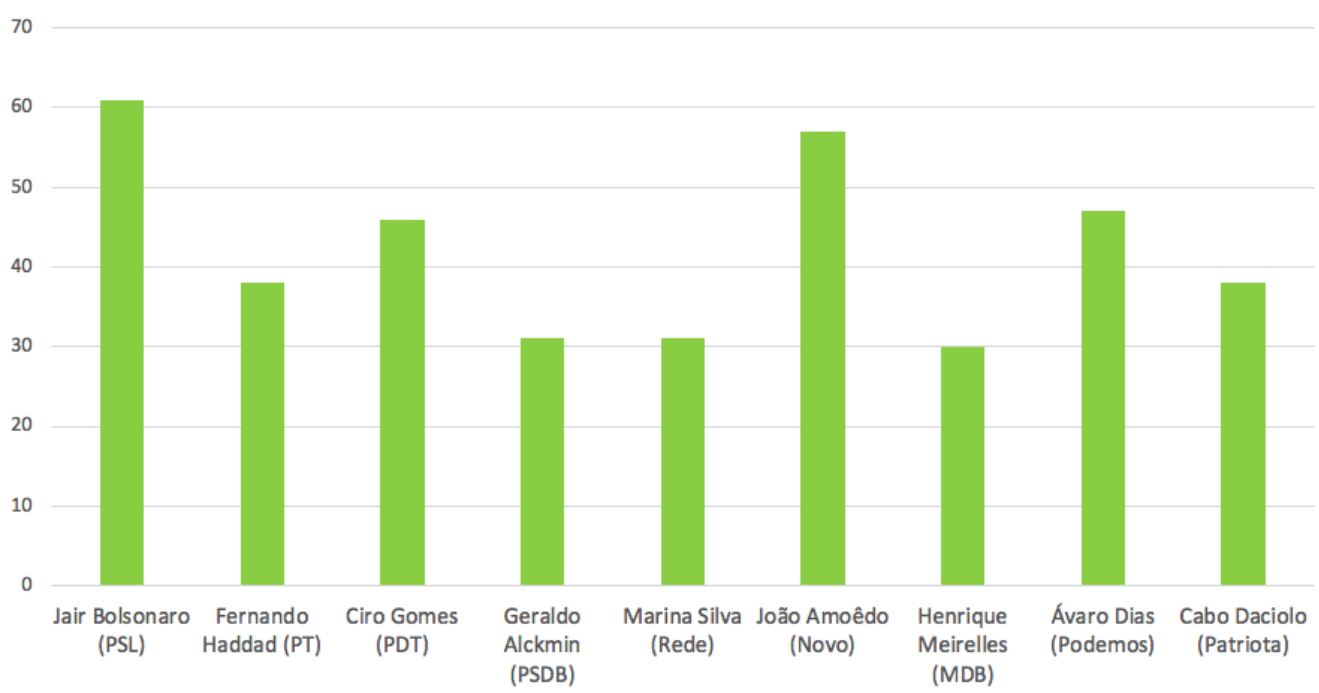

Fonte: Datafolha (2018).

Elaboração: Mait Bertollo.

Gráfico 24 - Percentual de eleitores que compartilham notícias sobre política brasileira e eleições por meio do aplicativo WhatsApp

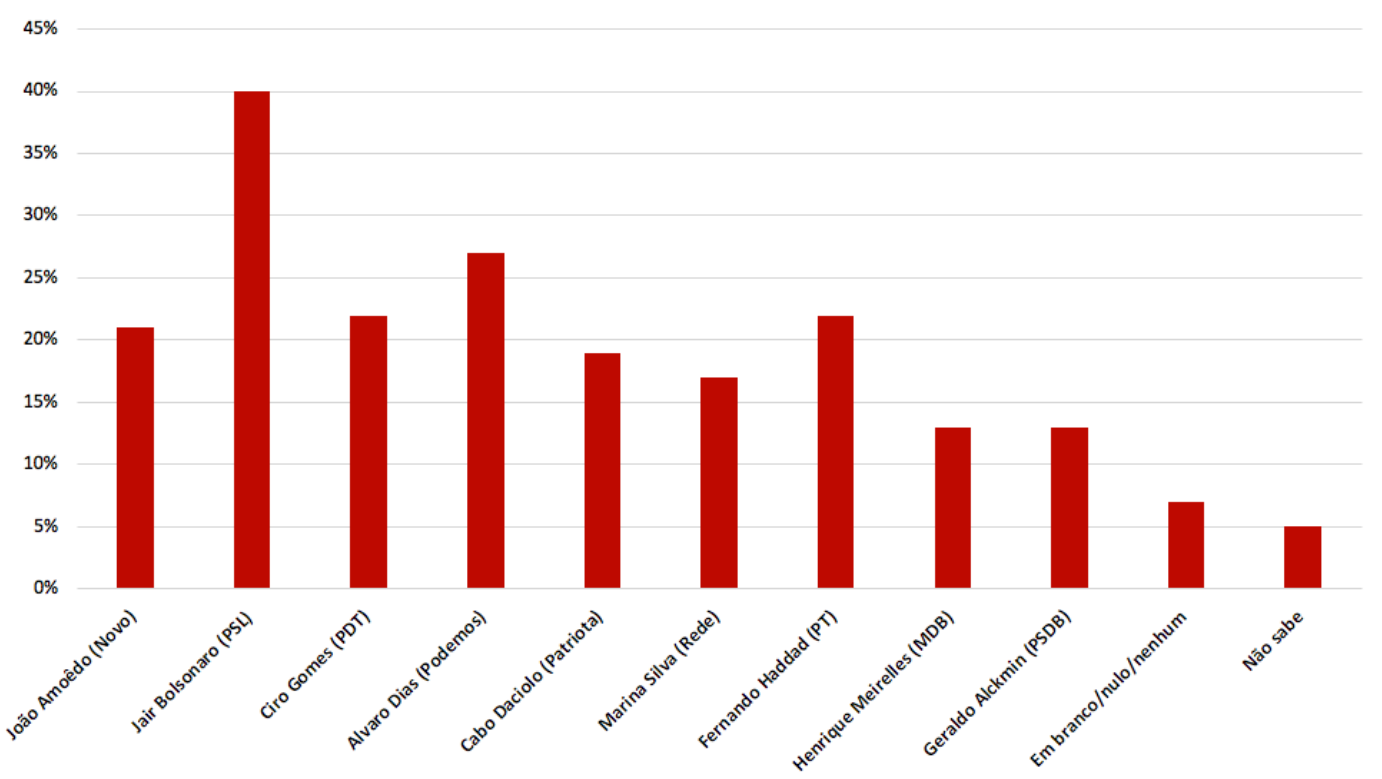

Fonte: Datafolha (2018).

Elaboração: Mait Bertollo.

Nesse contexto, a interação no território ultrapassa a relação hierárquica de empresas e Estado em direção aos indivíduos, mas também entre agentes individuais que produzem a contiguidade dessa rede e que podem promover uma nova forma de realizar e/ou influenciar políticas em várias escalas, nas metrópoles e nas cidades de menor porte, distantes dos grandes centros, que se transformam por meio de sucessivas combinações de objetos técnicos, fixos e fluxos. 
A participação nas redes sociais e a mudança das práticas comunicativas tornam complexas as relações entre os indivíduos e os conteúdos digitais; são impulsoras e também resultado da capilarização da informação por meio do smartphone no território brasileiro.

Essas infraestruturas têm uma conexão interescalar, fazendo fluírem informações em todas as escalas. Por meio do serviço de nuvem, que tem vários servidores nos EUA, de onde parte a criação dos robôs, por exemplo, os custos são menores para atuar em plataformas de diversos países, como o WhatsApp no Brasil, e esse serviço pode ser contratado de qualquer lugar do planeta.

A disseminação de notícias falsas é coibida pela Lei Eleitoral, que proíbe o uso de perfil falsos e robôs para propaganda eleitoral, bem como a compra de bancos de cadastro de usuários de internet e telecomunicações e o envio automático massivo de mensagens, como no caso WhatsApp. A mesma lei também prevê penalidades para a divulgação de informações falsas, e o Código Penal criminaliza casos de injúria, calúnia e difamação; porém, até a primeira semana de dezembro de 2018, esse marco normativo não havia sido efetivamente aplicado pela Justiça.

A Lei Geral de Proteção de Dados (LGPD), aprovada em agosto de 2018, criou uma autoridade independente para fiscalizar empresas e poder público no tratamento de dados, e sua implementação pode evitar a produção e distribuição individualizada e fabricada de conteúdos para grupos de eleitores nas próximas eleições.

Por outro lado, no aspecto normativo que regula o usuário, há mudanças no projeto da Lei Antiterrorismo, aprovada no começo de 2019 e que resultará em pena por apoio ou apologia ao terrorismo de acordo com o comentário, o like ou o compartilhamento de determinado conteúdo.

O Projeto de Lei do Senado n. 272/2016 da Lei Antiterrorismo pode criminalizar movimentos sociais e manifestações de qualquer tipo; tornando o cerceamento ainda mais rigoroso.

A alteração tipifica "atos preparatórios" de supostos "atos terroristas" por meio de eventos criados no Facebook, posts na internet, e qualquer manifestação popular poderia ser automaticamente enquadrada como ato terrorista por motivações "política, ideológica ou social" (SENADO NOTÍCIAS, 2018). 
O uso ilegal de dispositivos proibidos pela Lei Eleitoral foi ignorado pelo Google e pela Facebook, pois os disparadores de fake news foram contratados para disseminar desinformação de modo segmentado por meio de empresas que comercializam envio de mensagens por esse mecanismo. O WhatsApp e o Facebook podem entregar à Justiça Eleitoral os metadados ${ }^{46}$ dos envios massivos de mensagens no período eleitoral.

A maior parte da campanha presidencial de um dos candidatos não foi realizada nem por seu comitê oficial, nem por seu partido, mas por empresários que não declararam esse pagamento, e os metadados de disparos superiores a mil contatos por chip podem ser entregues para se chegar até as empresas que os criaram e organizaram. Assim, há uma fragilidade na regulação do WhatsApp, que não estabelece normas e não coíbe ilegalidades.

A corporação Facebook, proprietária do aplicativo WhatsApp, que é o mais utilizado no Brasil, possibilitou o vazamento massivo de dados de seus usuários a empresas de marketing especializadas para influenciar e manipular as emoções dos eleitores. A estratégia foi intensamente aplicada nos EUA, com a interferência do governo russo nas eleições presidências de 2016, usando as redes sociais para beneficiar o presidente eleito Donald Trump. A empresa Cambridge Analytica obteve dados de 87 milhões de usuários do Facebook - 70 milhões dos quais são estadunidenses -, com os quais traçou perfis de personalidade dos eleitores e direcionou conteúdo para influenciar os votos a favor de Trump. O Facebook admitiu a falha na proteção dos dados e pediu desculpas.

Fundada na Inglaterra em 2013, a Cambridge Analytica era uma divisão de sua controladora britânica, a SCL Group, e nasceu para participar das eleições nos EUA. Foi a primeira empresa do ramo a implantar tal estratégia de forma massiva, inicialmente nos EUA, onde possuía vários escritórios. Ela associa mineração e análise de dados com comunicação estratégica no processo eleitoral, tendo participado de 44 campanhas políticas em 2014. É propriedade da família do bilionário e conhecedor do funcionamento dos algoritmos Robert Mercer, que trabalhou na IBM e que gerencia fundos de investimentos. Mercer apoia muitas causas conservadoras e antidemocráticas, e é um dos principais doadores do Partido Republicano dos EUA e foi assessor próximo do presidente Donald Trump até 2017.

\footnotetext{
46 Metadados são informações sobre outros dados. Um item de um metadado pode dizer o que é certo dado e permite entender sua função e sua origem, seus atributos, tamanho, formato etc.
} 
Steve Bannon ${ }^{47}$ é outro agente importante, pois, como diretor geral da campanha de Trump e conselheiro estratégico da Casa Branca até 2017, tornou-se em 2018 conselheiro da campanha do então candidato à presidência Jair Bolsonaro para as atividades de inteligência, ações nas redes sociais e uso e análise de dados.

Em maio de 2018, a Cambridge Analytica registrou um pedido de falência, encerrando suas operações nos EUA e no Reino Unido por causa do escândalo do vazamento de dados do Facebook. Dividiu-se, então, em duas empresas: a CA Political, responsável por atividades no ramo da política, e a CA Commercial, responsável por investimentos financeiros.

Ao agregar e cruzar uma imensa massa de informações pessoais, infla-se o campo conservador, que envia a mensagem exata que o eleitor precisa ler ou ouvir para se comportar como queira a campanha. A manipulação de sentimentos em favor de estratégias eleitorais e a falta de transparência do uso dos dados pessoais, potencializadas pela capilarização da informação e pela banalização do smartphone no território brasileiro, onde há uma demanda reprimida de acesso aos meios de comunicação, resultaram na influência massiva das fake news como elemento relevante do resultado da eleição de 2018.

A técnica mais usada foram os anúncios microdirecionados, como aceleradores de informações insidiosas ou francamente falsas, com todos esses interesses hegemônicos como pano de fundo. Para o disparo massivo de mensagens de WhatsApp, as empresas que apoiaram campanhas eleitorais de determinado candidato pagaram valores de até $\mathrm{R} \$ 12$ milhões em contratos que não foram declarados à Justiça Eleitoral, e as bases de dados telefônicos teriam sido obtidas lícita e ilicitamente. Assim, a dita força política de algumas candidaturas nas redes sociais resulta de um esforço distribuído e capilarizado por meio de listas de números de telefone, usando o WhatsApp.

\footnotetext{
47 Além de trabalhar para a Cambridge Analítica, o milionário Bannon foi banqueiro, produtor de filmes, executivo de mídia e proprietário do site de notícias de extrema-direita Breitbart News. Além de influenciar as eleições nos EUA para a eleição de Donald Trump e no Brasil para eleger Jair Bolsonaro, ele lançou uma operação europeia chamada Movimento, com sede em Bruxelas, que é uma consultoria política a partidos de extrema-direita para acessar dados de usuários das redes sociais e processá-los (GRAGNANI, 2018). Também dá conselhos sobre campanhas de mídia social, que visam dar uma face palatável ao populismo de extremadireita para eleger um candidato. Suas ações se concentram principalmente na Bélgica, na Itália, na Holanda e na França, com o objetivo de influenciar as eleições do parlamento europeu em 2019, formando uma coalizão ultraconservadora e dando suporte estratégico a partidos de extrema-direita. Embora as leis eleitorais de muitos países europeus impeçam que indivíduos ou organizações internacionais interfiram em eleições nacionais por meio de serviços de pesquisa ou outro tipo de apoio, há um risco real de Bannon intervir na próxima composição do parlamento.
} 
Essa infraestrutura de propaganda é eficiente quando administradores de grupos se coordenam e passam a atuar como nós da rede, por concentrar muitas conexões e gerir trabalho pago com estrutura descentralizada. Os gastos declarados à Justiça Eleitoral abrangem também pagamentos para que empresas de comunicação prestem serviços de alimentação de grupos de WhatsApp; assim, sua eficiência depende de adesão às mensagens, da conjuntura política e dos sentimentos das pessoas e pode aumentar as chances de essas mensagens serem passadas adiante.

Durante as campanhas eleitorais em 2018, o trabalho profissional contratado para alimentar as redes vem sendo erigido desde 2013, durante as manifestações de junho, ganhando eficiência e amplitude à medida que os conteúdos se repassavam e eram transformados por outras plataformas.

Nesse contexto, o evento é o portador de algumas das possibilidades existentes num país, numa região ou num lugar em dado período histórico e em dado recorte espacial (SANTOS, 1997). Nesse sentido, as eleições foram a materialização do evento nos lugares, pois a escala é o "o depositário final, obrigatório do evento e se dá empiricamente como funcionalização do todo" (SILVEIRA, M., 2002a, p. 205) e revela o processo e o movimento das possibilidades.

A lógica da capilarização das informações pelo território não se aplica isoladamente, mas por meio de um conjunto sistêmico de eventos que altera a materialidade do território e permite distinguir entre antes e depois dos eventos (SANTOS, 2006).

Assim, quando observamos a escala global, o comando das ações de interesses hegemônicos transcende sua escala de origem e, num movimento vertical, atinge nos lugares os pontos onde se capilariza a informação pelo smartphone e se concretiza o acesso às informações pelo WhatsApp.

Essa dinâmica indica uma interdependência dos eventos nos níveis global e local, cujos resultados dependem de variáveis das particularidades do lugar e da formação socioespacial, em que o "salto de escala" (SMITH, 2004) dos agentes hegemônicos da informação produzem mudanças profundas no uso do território brasileiro, tornando-o mais racionalizado e corporativo para agentes hegemônicos políticos e econômicos por meio da capilarização da informação pelo uso popularizado do smartphone. 


\section{CONCLUSÃo}

Transformados em mitos, através de estratégias comunicacionais orientadas por mínimas pautas políticas, os atuais donos do poder personificam interesses corporativos que enfraquecem referências culturais indispensáveis à própria estabilidade da esfera política.

Ana Clara Torres Ribeiro, 2005

A banalização das tecnologias da informação e comunicação possibilitou o uso corporativo do território de forma mais racionalizada pelos agentes hegemônicos da economia e da política conferindo novos usos ao território. A emergência do smartphone introduziu a maior parte da população no uso cotidiano da informação. Mas é importante levar em conta que, se por um lado esse acesso oportuniza uma conexão massiva, por outro oculta a perversidade aí embutida: a vulnerabilidade de grande parte dos cidadãos em lidar com a racionalidade das informações produzidas por tais agentes.

Assim, essa situação impõe considerar os fatos técnicos e políticos que são ao mesmo tempo dialéticos e conexos. Do mesmo modo que a informação é carregada de intencionalidades articuladas pelo poder hegemônico, esta nova tecnologia também abriu novas possibilidades e contra-racionalidades (SANTOS, 1996) que expressam a reação dos agentes não-hegemônicos. Um exemplo paradigmático é a importante atuação e influência dos provedores regionais na maior parte do território nacional, em cidades de 5 mil até $50 \mathrm{mil}$ habitantes que têm demanda de conexão, mas não eram atendidas por grandes empresas ou o valor do serviço seria muito alto para a renda da população. Assim, esses provedores têm o papel de popularizar o acesso em cidades que ficam distantes de grandes centros urbanos, num contexto em que se abrem possibilidades para os "pequenos" dentro de uma rede hegemonizada.

Dentro da apreciação das contra-racionalidades, a banalização do uso do smartphone para acesso a internet tem o poder de redefinir setores da economia urbana, como as atividades marginais, tradicionais ou recentemente marginalizadas. E nos espaços menos modernos e mais "opacos" propiciam uma adaptação criadora à realidade existente, conforme afirma SANTOS, 1988.

Logo, há potenciais possibilidades para os trabalhadores dos chamados circuito superior marginal e circuito inferior da economia (SANTOS, 1996), considerando as bases materiais do período que são a unicidade da técnica, a convergência dos momentos e o 
conhecimento do planeta (SANTOS, 2000b), que poderão servir a outros objetivos sob fundamentos sociais e políticos.

Tais possibilidades técnicas podem promover a emancipação social, em que o receptor das mensagens, isto é, o usuário do smartphone, pode também produzir e difundir informações, com diferentes conteúdos (textos, imagens, sons) ou pelo alcance ao conhecimento acessível e independente para constituir redes e até mesmo, em determinados casos, elaborar aplicativos para uso de grupos locais ou regionais.

Considerar as contra-racionalidades como possibilidade de emancipação social exige uma reflexão sobre o movimento de totalização do período que atravessamos, na medida em que se constata o mútuo condicionamento entre transformações técnicas e transformações sociais. Temos assim a sucessão contínua da concepção espaço-tempo que Santos (1996) analisava como "conjuntos de sistemas de objetos indissociáveis dos conjuntos dos sistemas de ações" para caracterizar o movimento da produção material da sociedade. No período atual, a informação está no cerne da inseparabilidade entre os objetos técnicos e as ações sociais.

O ápice que conhecemos, até aqui, das possibilidades de manipulação de informações pelo objeto técnico smartphone foi a eleição presidencial e parlamentar de 2018, diretamente relacionada ao uso do WhatsApp. No entanto, é preciso considerar que malgrado esse uso perverso da informação, o exercício de compreensão da totalidade demanda um olhar para além do caráter nocivo do uso do smartphone, afinal ele permite um uso econômico e político de emancipação e de criação de solidariedades sociais, como se pode perceber pela crescente importância do smartphone no cotidiano dos cidadãos, inclusive daqueles com menor poder aquisitivo.

Nas eleições de 2018, tivemos uma mostra empírica da complexidade socioespacial implicada e consequentemente das possibilidades inquietantes postas por esse objeto técnico, visto que esse evento foi concomitante com a capilarização da informação pelo smartphone.

Investigar esse problema entendendo o espaço geográfico como instância social (SANTOS, 1996) nos permitiu aprofundar as relações que se estabelecem entre o conjunto de sistemas técnicos relacionados ao smartphone vinculado às mudanças mais ou menos profundas na sociedade contemporânea e no uso do território brasileiro. 
Deste modo, pudemos analisar como o smartphone engendra uma nova trama no meio técnico-científico-informacional (SANTOS, 1994), já que seu uso se dá por meio de sistemas técnicos que, distribuídos pelo território em áreas contíguas ou não, em pontos ou manchas, acentuam a racionalidade da capilarização da informação chegando a muitos e variados indivíduos e grupos de modo concomitante, o que aponta para um novo uso do espaço-tempo. Paradoxalmente, essa racionalidade foi utilizada para potencializar a irracionalidade das fake news, atingindo verticalmente as parcelas da população mais vulneráveis, um claro exemplo daquilo que SANTOS (2000b) chamou de "violência da informação".

Assim, é possível afirmar que corporações e o Estado impuseram uma adequação técnica e política a várias porções do território, permitindo que seus serviços, intenções, mensagens e influência retornassem como lucro e poder para esses agentes.

Os sistemas técnicos, presentes sobretudo nas cidades, conectam smartphones à internet criando condições materiais e políticas para uso dos agentes hegemônicos, pois abrangem uma área de atuação que usualmente envolve diversas regiões, países e continentes, constituindo um sistema transnacional concentrado num número pequeno de agentes controladores, que são capazes de interferir na distribuição e no conteúdo das informações e de dados que trafegam por suas redes, visando atingir um número cada vez maior de pontos.

A capilarização desse sistema, que se intensifica no Brasil a partir dos anos 2000, se deu principalmente pelas inovações no âmbito da comunicação e pela sofisticação dos objetos técnicos para atingir e integrar cada usuário à rede que recebe e emite informações em vários pontos do território.

A extremidade dessa rede, que é o usuário do smartphone, está sujeita à instabilidade dessas ordens e ao condicionamento de seu comportamento, provenientes de uma direção vertical. Esse fato marca as relações do Estado, das empresas e dos indivíduos e do próprio território; a cada mudança causada pela capilarização da informação, segue-se a necessidade de adaptação às novas ordens e às desordens, visto que "a desordem, a cada momento, é diferente da desordem precedente e da desordem seguinte [...] a atividade corporativa que se realiza por intermédio de empresas-rede, influencia a totalidade ou partes significativas do território" (SANTOS, 1999, p. 45).

Logo, por meio dos sistemas técnicos compostos por cadeias de humanos e não humanos, as intenções das ações de informar e comunicar, principalmente as exógenas, 
atingem o território, muitas vezes com potencial para gerar uma crise de identidade (SANTOS, 1999).

Em muitos países, já não se concebe atividades políticas sem o uso das redes sociais ou o acesso à internet. Os meios digitalizados de comunicação engendram novas práticas e condutas e o consumo e a produção de informações e de "verdades" se descentralizam e são prioridades das agendas políticas, assim como os cidadãos dependem cada vez mais do smartphone para se informar e articular suas percepções e preferências.

Esse movimento é inerente à implantação das infraestruturas técnicas necessárias ao funcionamento da rede capilarizada do smartphone, concomitante à manipulação dos dados dos usuários dessa rede para influenciar práticas sociais. Esse procedimento se expande para todos os centros urbanos do planeta.

As maiores corporações do ramo da internet e detentoras de rede serviço e rede suporte são a Google e a Facebook, que controlam a privacidade e os dados de todos os seus bilhões de usuários. As estratégias de capilarizar, adensar e estender suas redes visam controlar a valorização do espaço influenciando as práticas espaciais da sociedade na política, na economia e na cultura.

Entendemos que a capilarização da informação por meio do smartphone, a expansão do meio técnico-científico-informacional e a banalização do acesso à internet tendem a disponibilizar e democratizar o acesso aos meios de comunicação e informação. Por outro lado, sem regulação e por meio dos diversos agentes econômicos e políticos que detêm o poder sobre a técnica que capta e condiciona o comportamento dos usuários, pode acontecer o contrário: a supressão da democracia.

As crises do sistema democrático não são novas, mas agora contêm mais um elemento relativo ao período técnico-científico-informacional: o uso pessoal de dispositivos que recebem, produzem e compartilham ideias de forma rápida e eficiente. Por isso, são ferramentas potentes, usadas por agentes com grande poder econômico, que podem ser tanto corporações quanto indivíduos ligados à política, principalmente a eventos eleitorais, como emergentes grupos de bilionários que têm condições de promover governos antidemocráticos.

Esses eventos se desenvolvem no período presente, e ainda não se sabe a magnitude de seu impacto. Ao mesmo tempo, as instituições democráticas, as normas, os territórios, os 
lugares e as pessoas não logram ainda agir na mesma velocidade, nem impedir ou ao menos dar uma resposta a fim de evitar ou atenuar o impacto nocivo desse tipo de estratégia. Há um descompasso entre o tempo de ação desses elementos e o da chamada inteligência artificial.

Nesse contexto, para concretizar um poder hegemônico sobre os meios de comunicação, assistimos a disputas e também parcerias entre corporações ligadas à televisão ou à internet que passam pelos discursos, pela noção de verdade dos fatos, pela representatividade e pelo cumprimento efetivo das normas de um sistema democrático. Há, portanto, o risco de uma concentração de poder sem medidas por poucos agentes, capazes de capturar dados comportamentais dos bilhões de usuários da internet para disseminar ordens e, de forma refinada, segmentada e exclusiva, manipular condutas numa escala planetária.

A transformação dos territórios tem outros vetores, dados por componentes que perfazem uma cadeia de humanos e não humanos: trata-se dos algoritmos e da inteligência artificial, técnicas que visam atingir os chamados micro targets (microalvos). Para tanto, classifica-se cada usuário por meio de marketing digital, processam-se grandes bancos de dados, com amostras precisas de cada pessoa, e se cruzam informações e cadastro para vendêlos, sem que os usuários ao menos suspeitem que geram uma abundância de dados toda vez que usam sites ou aplicativos.

Essa estratégia é artificiosa a partir do momento em que, além do objetivo comercial, também se aplica à política, como no caso da campanha eleitoral apontada aqui. Por meio do pagamento de impulso a conteúdos da internet e da compra ou da captura de dados, seja dos usuários do Facebook ou das buscas realizadas pelo Google, processam-se dados de modo a reconhecer os traços de personalidade de cada usuário, ao se utilizarem essas informações para persuadir indivíduos seja para o consumo, para notícias falsas (fake news) etc. Isso pode incitar diferentes sentimentos nas pessoas, corroborando diferentes tomadas de decisão pelo indivíduo.

Atualmente há empresas que oferecem serviços e que produzem tecnologia visando desenvolver e aplicar algoritmos e inteligência capaz de influenciar as ações dos indivíduos. A inteligência artificial ainda está numa etapa de desenvolvimento que não permite compreender plenamente seus significados, ou seja, os sistemas de aprendizagem artificial não são confiáveis (SHAO et al., 2018). Os programas podem não ser eficientes quando confrontados com situações que diferem, mesmo pouco, daquilo em que foram programados, 
e, quando isso acontece, cometem erros às vezes desastrosos, tais como confundir pessoas inocentes com criminosos e sentencia-los num sistema de reconhecimento digital de rosto ou na análise de dados e de atividades em redes sociais. Os métodos para incutir na IA sistemas de "bom senso intuitivo" ou "habilidades de generalização humanitária" ainda são pouco sofisticados (SHAO et al., 2018).

Os programas que buscam inferir sobre aspectos comportamentais humanos vêm sendo aplicados à situações reais, e, enquanto há uma preocupação com a IA "superinteligente", seu aspecto mais perigoso é a excessiva confiança e autonomia desses sistemas limitados que, apesar disso, já dominam estratégias nos campos da economia e da política. A corrida para o uso e comercialização da IA pressiona a produção de sistemas que funcionem "suficientemente bem" em diferentes tarefas.

A função dos robôs, ou bots, também é primordial na interferência em comportamentos por meio de redes sociais e pelo uso de algoritmos, pois eles têm técnicas muito eficazes para espalhar informações, sobretudo as falsas, pois muitos são criados com esse fim. Por exemplo, dos 14 milhões de mensagens compartilhadas no Twitter entre maio de 2016 e maio de 2017 envolvendo as eleições e a posse de Donald Trump, só 6\% das contas do Twitter identificadas como bots espalhavam 31\% das fake news, conseguindo esse resultado de dois a dez segundos, por meio de amplificação automatizada (SHAO et al., 2018).

Os usuários tendem a confiar mais em mensagens que parecem provir de muitas vozes e a prestar mais atenção ao que parece popular. Os bots criam a aparência de popularidade fazendo crer que determinada opinião é mais amplamente aceita do que realmente é; os indivíduos são levados a compartilhar essas mensagens, que trafegam mais longe, mais depressa, mais profunda e amplamente do que as notícias verdadeiras (SHAO et al., 2018).

Assim, muitos têm a impressão de que estão interagindo sem mediações, o que pode diminuir sua capacidade crítica e levá-los a compartilhar ou acreditar em informações falsas, agindo como "inocentes úteis" que se põem a disseminar essas informações tanto quanto os robôs (SHAO et al., 2018).

Os bots podem ter efeito socialmente positivo quando, por exemplo, amplificam alertas de emergência. Por isso, toda ferramenta depende do modo como é usada e, posto que a ciência, a técnica e a informação, imbuídas de intencionalidades, comandam a produção e o uso dos objetos, também impregnam ações e determinam normas (SANTOS, 2000a). 
Quando estão conectados e têm acesso ao que Santos (1994) chamou de “cognoscibilidade planetária", o poder de influência sobre o comportamento dos indivíduos atravessa as escalas e tem um resultado avassalador no território e nas interações espaciais. $\mathrm{O}$ poder de um bilionário dos EUA pode influenciar a vida cotidiana de uma pessoa numa cidade remota do Brasil e, ao mesmo tempo, de milhões de pessoas em qualquer ponto do planeta, por meio de algoritmos, condicionando o funcionamento interescalar de qualquer formação socioespacial, visto que as fronteiras nacionais não são empecilhos para essas ordens. E o smartphone é o objeto técnico que mais facilmente realiza essa função, dada sua popularização no que tange ao acesso a informações.

Ao tomar os usos do território pelos agentes hegemônicos ou por aqueles que agem sob sua influência, consideramos os lugares que comandam e os lugares que obedecem a partir desses fluxos de informação. Essa verdadeira violência é também entendida em virtude da desinformação e do envio massivo de notícias falsas, apresentando-se carregada de uma racionalidade que agencia necessidades, medos, preconceitos, idiossincrasias e insatisfações e engendra, ao fim e ao cabo, irracionalidade.

É importante por em relevo que esse fenômeno não seria possível sem um conjunto de sistemas técnicos que dão o suporte ao funcionamento e à capilarização das informações pelo smartphone, fundamentais na vida social e econômica, com um domínio centralizado em grandes empresas globais.

Crescentemente ligadas à produção de notícias falsas e à publicidade e reforçando o consumo conspícuo (SANTOS, 2000b), as informações são impregnadas de conteúdo ideológico e a relação dos sentidos é transformada: quando uma sociedade inventa e adota uma tecnologia que dá predominância ou nova importância a um ou mais sentidos, a informação pode ser ouvida e vista e os poderes que daí derivam não são da mesma natureza (MCLUHAN, 1977). E para que seu resultado no território seja socialmente positivo, é preciso que haja grande mobilização para que seu uso seja transformado por regulação e conhecimento sobre as redes informacionais do atual período, considerando o poder híbrido das técnicas constituídas de cadeias de humanos e não humanos para capilarizar informações influentes e dominantes no território. 


\section{REFERÊNCIAS}

ABAGNANO, N. Técnica. Dicionário de Filosofia. São Paulo: Mestre Jou, 1982. p. 905906.

ABRAMOVAY, P. Distopia digital. Quatro Cinco Um, São Paulo: Polem, v. 1, n. 2, p. 6-7, jun. 2017.

ABRANET. ASSOCIAÇÃO BRASILEIRA DE INTERNET. Pequenos provedores impulsionam o crescimento do mercado de Telecom no Brasil, 2017. Disponível em: $\quad<\mathrm{http} / /$ www.abranet.org.br/Noticias/Pequenos-provedores-impulsionam-ocrescimento-do-mercado-de-Telecom-no-Brasil-

1514.html?UserActiveTemplate=site\#.W-Crty3OoWo>. Acesso em: 10 fev. 2018.

ADORNO, T. W.; HORKHEIMER, M. Dialética do esclarecimento: fragmentos filosóficos. Rio de Janeiro: Zahar, 1985.

AFFONSO, R. B. A. A Federação no Brasil: impasses e perspectivas. In: AFFONSO R. B. A.; SILVA, P. L. B. (Org.). Desigualdades regionais e desenvolvimento. São Paulo: Fundap/Unesp, 1995. p. 31-62.

ALEXA AMAZON COMPANY. Top sites in Brazil, 2018. Disponível em: $<$ https://www.alexa.com/topsites/countries/BR>. Acesso em: 30 out. 2018.

ALVAREZ, C. S. Brasil conectado: o Programa Nacional de Banda Larga e perspectivas para 2011-2014. (Palestra proferida no 54 Painel Telebrasil: Informação \& (Tele) Comunicação Multimídia. Revista de Direito, Estado e Telecomunicações, v. 3, n. 1, p. 281-294, 2011.

ANATEL. AGÊNCIA NACIONAL DE TELECOMUNICAÇÕES. Sinal analógico será desligado no Norte e Nordeste, 2018a. Disponível em: $<$ http://www.anatel.gov.br/institucional/noticias-destaque/1982-sinal-analogico-seradesligado-no-norte-e-nordeste>. Acesso em: 10 ago. 2018.

ANATEL. AGÊNCIA NACIONAL DE TELECOMUNICAÇÕES. Setor Regulado: Conecta Brasil, 2018b. Disponível em: $<\mathrm{http}: / / \mathrm{www}$.anatel.gov.br/setorregulado/component/content/article/2uncategorised/428-conecta-brasil>. Acesso em: 1 nov. 2018.

ANATEL. AGÊNCIA NACIONAL DE TELECOMUNICAÇÕES. Lei n. 9.295, de 19 de julho de 1996, 2017a. Disponível em: <http:/www.anatel.gov.br/legislacao/leis/473lei-9295>. Acesso em: 19 jul. 2018.

ANATEL. AGÊNCIA NACIONAL DE TELECOMUNICAÇÕES. Seminário Conecta Brasil: provedores regionais e massificação do acesso à internet. Superintendência de Planejamento e Regulamentação - SPR, 2017b. Disponível em: $<\mathrm{http} / / /$ www.anatel.gov.br/Portal/documentos/sala_imprensa/6-7-2017--15h25min0s5_Conecta\%20Brasil_SPR.pdf>. Acesso em: 13 jun. 2018. 
ANATEL. AGÊNCIA NACIONAL DE TELECOMUNICAÇÕES. Informações técnicas, 2016. Disponível em: <http://www.anatel.gov.br/Portal/exibirPortalInternet.do? acao=inicioConteudo\&site=1 \&visao=5>. Acesso em: 19 jul. 2016.

ANATEL. AGÊNCIA NACIONAL DE TELECOMUNICAÇÕES. Decreto n. 6.654, de 20 de novembro de 2008. Disponível em: <http://www.anatel.gov.br/legislacao/decretos/ 52-decreto-6654>. Acesso em: 16 ago. 2018.

ANDERSON, Chris. A cauda longa. Rio de Janeiro: Elsevier, 2006.

ANGELUCI, A. C. B. Características e habilidades no ambiente digital: a cultura participativa sob os aportes de Jenkins e Murray. Comunicação \& Inovação, PPGCOM-USCS, v. 15, n. 29, p. 51-60, jul./dez. 2014.

ANTAS JR., R. M. Notas sobre o uso do conceito de circuitos espaciais produtivos para estabelecer o nexo entre a reestruturação urbana e as refuncionalizações do espaço: um estudo sobre os fixos de saúde no estado de São Paulo. In: ENCONTRO NACIONAL DA ASSOCIAÇÃO NACIONAL DE PÓS-GRADUAÇÃO E PESQUISA EM PLANEJAMENTO URBANO E REGIONAL, 14., 2011, Rio de Janeiro. Anais... Rio de Janeiro: Anpur, 2011. v. 14. p. 1-15.

ANTAS JR., R. M. O consumo contemporâneo no território brasileiro. In: Ricardo Mendes Antas Jr. (Org.). Desafios do consumo. Petrópolis, RJ: Vozes, 2007. p. 91-114.

ANTAS JR., R. M. Território e regulação - espaço geográfico: fonte material e não-formal do direito. São Paulo: Humanitas, 2005.

ANTUNES, R. Os sentidos do trabalho: ensaio sobre a afirmação e a negação do trabalho. São Paulo: Boitempo, 2003.

AQUILES, A. C. A realidade do trabalho nas telecomunicações: o caso das empresas-espelho. In: SIMPÓSIO LUTAS SOCIAIS NA AMÉRICA LATINA: IMPERIALISMO, NACIONALISMO E MILITARISMO NO SÉCULO XXI, 4., 2010, Londrina. Anais... Londrina: UEL, 2010. p. 16-27.

ARROYO, M. Território nacional e mercado externo: uma leitura do Brasil na virada do século XX. Tese (Doutorado em Geografia Humana) - Faculdade de Filosofia, Letras e Ciências Humanas, Universidade de São Paulo, São Paulo, 2001.

ASSANGE, J. Quando o Google encontrou o WikiLeaks. São Paulo: Boitempo, 2015.

ATLAS BRASILEIRO DE TELECOMUNICAÇÕES. Converge Comunicações/Teletime, Ipsis, São Paulo, 2014. Disponível em: $<$ https://issuu.com/telaviva/docs/atlas2014_site_baix2>. Acesso em: 20 jul. 2016.

ATLAS DA NOTÍCIA. 30 milhões de pessoas vivem em desertos de notícia, 2018. Disponível em: <https://www.atlas.jor.br/estatisticas/>. Acesso em: 27 nov. 2018.

AUGÉ, M. Não-lugares: introdução a uma antropologia da supermodernidade. São Paulo: Papirus, 1994. 
BAROCAS, S.; HOOD, S.; ZIEWITZ, M. Governing Algorithms: A Provocation Piece, 2013. Disponível em: <https://ssrn.com/abstract=2245322 or http://dx.doi.org/10.2139/ssrn.2245322>. Acesso em: 13 jun. 2018.

BARRÁGAN, F. M. Los conceptos de jerarquía y heterarquía en el análisis de desarollo local. In: ROSALES, R. (Org.). Desarrollo local: teoría e practicas socioterritoriales. México: Metropolitana Istapalapa, 2007. p. 75-97.

BASTOS, M. T. Medium, media, mediação e midiatização: a perspectiva germânica. In: MATTOS, M. A.; JANOTTI JUNIOR, J.; JACKS, N. (Org.). Mediação \& midiatização. Salvador: Ed. UFBA, 2012. p. 53-77.

BAUDRILLARD, J. Para uma crítica da economia política do signo. Lisboa: Edições 70, 1995.

BAUDRILLARD, J. A moral dos objetos: função signo e lógica de classe. In: MOLES, A. A.; BAUDRILlARD, J.; BOUDON, P.; LIER, H. V.; WAHL, E. Semiologia dos objetos. Petrópolis, RJ: Vozes, 1972. p. 61-88.

BEGAG, A.; CLAISSE, G.; MOREAU, P. L' espace des bits utopies et réalités. In: BAKIS, H. (Ed.). Communication et territoires. Paris: La Documentation Française, 1990. p. $187-217$.

BENAKOUCHE, T. Tecnologia é sociedade: contra a noção de impacto tecnológico. Cadernos de Pesquisa, Florianópolis: UFSC, n. 17, set. 1999.

BENAKOUCHE, T. Redes de comunicação eletrônica e desigualdades regionais. In: GONÇALVES, M. F. P. (Org.). O novo Brasil urbano. Porto Alegre: Mercado Aberto, 1995. p. 227-237.

BERGSON, H. A evolução criativa. Paris; PUF, 1989.

BERMAN, M. Tudo que é sólido desmancha no ar: a aventura da pós-modernidade. 3. ed. São Paulo: Companhia das Letras, 1992.

BIJKER, W. E.; LAW, J. (Org.). Shaping technology/building society: studies in sociotechnical change. Cambridge, MA: The MIT Press, 1992.

BIJKER, W. E.; HUGHES, T. P.; PINCH, T. (Org.). The social construction of technological systems: new directions in the sociology and history of technology. Cambridge, MA: The MIT Press, 1987.

BIJKER, W. E.; PINCH, T. F. The social construction of facts and artifacts: Or how the Sociology of Science and the Sociology of Technology might benefit each other. In: BIJKER, W. E.; HUGHES, T. P.; PINCH, T. (Org.). The social construction of technological systems: new directions in the sociology and history of technology. Cambridge, MA: The MIT Press, 1987. p.17-50.

BLABLACAR. BlaBlaCar completa dois anos no Brasil com 1,6 milhão de usuários e 38 mil rotas, $2017 . \quad$ Disponível em: $<$ https://blog.blablacar.com.br/newsroom/noticias/blablacar-completa-dois-anos-nobrasil-com-1-6-milhao-de-usuarios-e-38-mil-rotas>. Acesso em: 12 fev. 2018. 
BOLTANSKI, L.; CHIAPELLO, E. O novo espírito do capitalismo. Tradução Ivone C. Benedetti. Revisão técnica Brasílio Sallum Jr. São Paulo: WMF Martins Fontes, 2009.

BRASIL. Presidência da República. Secretaria de Comunicação Social. Pesquisa brasileira de mídia 2015: hábitos de consumo de mídia pela população brasileira. Brasília: Secom, 2014. Disponível em: <http://www.secom.gov.br/atuacao/pesquisa/lista-depesquisas-quantitativas-e- qualitativas-de-contratos-atuais/pesquisa-brasileira-demidia-pbm-2015.pdf>. Acesso em: 20 jul. 2016.

BRESCIANI, A. A. Sociedade em rede: faces virtuais da ideologia capitalista do século XXI. Dissertação (Mestrado em Sociologia) - Universidade Estadual Paulista, Marília, 2007.

BRETON, P. Histoire de l'informatique. Paris: La Découverte, 1987.

BRITO, M. Subsídios para a historia da telefonia no Brasil. Rio de Janeiro: NEC, 1976.

BROADBAND COMISSION FOR SUSTAINABLE DEVELOPMENT. The State of Broadband 2015: Broadband as a Foundation for Sustainable Development, 2015. Disponível em: $<$ http://www.broadbandcommission.org/publications/Pages/SOB2015.aspx>. Acesso em: 24 jul. 2016.

CADERNOS TEMÁTICOS DO OBSERVATÓRIO SOFTEX. Economia da Informação e internet. Campinas, SP: Softex/Publit, 2013. Disponível em: $<$ http://www.softex.br/projetos-para-o-setor/observatorio/cadernos-tematicos/ $>$. Acesso em: 12 ago. 2016.

CADWALLADR, C.; GRAHAM-HARRISON, E. Revealed: 50 million Facebook profiles harvested for Cambridge Analytica in major data breach. The Cambridge Analytica Files - The Guardian, 17 mar. 2018. Disponível em: $<$ https://www.theguardian.com/news/2018/mar/17/cambridge-analytica-facebookinfluence-us-election>. Acesso em: 12 jul. 2018.

CALLON, M. Society in the making: the study of technology as a tool for sociological analysis. In: BIJKER, W. E.; HUGHES, T. P.; PINCH, T. (Org.). The social construction of technological systems: new directions in the sociology and history of technology. Cambridge, MA: The MIT Press, 1987. p. 83-103.

CASTELLS, M. Communication power. New York: Oxford University Press, 2009.

CASTELLS, M. A galáxia da internet: reflexões sobre a internet, os negócios e a sociedade. Rio de Janeiro: Jorge Zahar, 2003.

CASTELLS, M. La era de la información: economia, sociedad y cultura Madrid: Alianza, 1997. v. 1: La sociedad red.

CASTILLO, R. A. Mobilidade geográfica e acessibilidade: uma proposição teórica. Geousp Espaço e Tempo (On- line), v. 21, n. 3, p. 644-649, dez. 2017.

CASTILlO, R. A. A imagem de satélite: do técnico ao político na construção do conhecimento geográfico. Pro-Posições, Campinas, v. 20, n. 3, p. 61-70, set./dez. 2009. 
CASTILlO, R. A. Sistemas orbitais e uso do território: integração eletrônica e conhecimento digital no território brasileiro. Tese (Doutorado em Geografia Humana) - Faculdade de Filosofia, Letras e Ciências Humanas, Universidade de São Paulo, São Paulo, 1999.

CASTRO, I. E. O problema da escala. In: CASTRO, I. E; GOMES, P. C. C.; CORRÊA, R. L. (Org.). Geografia: conceitos e temas. 2. ed. Rio de Janeiro: Bertrand Brasil, 1995. p. 115-140.

CATELAN, M. J. A heterarquia urbana como proposta metodológica: dissonâncias no ritmo e no arranjo espacial da rede urbana e do mapa da indústria do estado de São Paulo. In: SPOSITO, E. S. (Org.). Medidas antidumping e política doméstica: o caso da citricultura estadunidense [online]. São Paulo: Ed. Unesp, 2015. Disponível em: $<$ http://books.scielo.org/id/6y9nc/pdf/sposito-9788568334669-10.pdf > . Acesso em: 15 out. 2017.

CATELAN, M. J. Heterarquia urbana: interações espaciais interescalares e cidades médias. São Paulo: Cultura Acadêmica, 2013.

CERASOLI. L. T. Telecomunicações no Brasil. In: WOHLERS, M.; PLAZA, C. Informe anual 2000: telecomunicações e tecnologias da informação. São Paulo: Celaet/Uniemp, 2000.

CHAMAYOU, G. Teoria do drone. São Paulo: Cosac Naify, 2015.

CHESNAIS, F. A mundialização do capital. São Paulo: Xamã, 1996.

CHRISTAlleR, W. Central Places in Southern Germany. New Jersey: Prentice-Hall, 1966.

CHUPADADOS. A face oculta das nossas tecnologias de estimação, 2018. Disponível em: $<$ https://chupadados.codingrights.org $>$. Acesso em: 12 ago. 2018.

CLAVAL, P. Réseaux territoriaux et enracinement. In: DUPUY, G. (Ed.). Réseaux territoriaux. Caen: Paradigme, 1988. p. 147-161.

CLAVAL, P. Le système urbain et les réseaux d'information. Révue de Géographie de Montreal, v. XXVII, n. 1, p. 5-15, 1973.

CNN MONEY. Facebook and Microsoft are building a giant cable under the sea, maio 2016. Disponível em: <http://money.cnn.com/2016/05/26/technology/facebook- microsoftcable-marea/index.html?sr=twCNN052716facebook-microsoft-cablemarea0128AMStoryPhoto\&linkId=24921695>. Acesso em: 24 jul. 2016.

COINMAP. Concentração geográfica de operações com moedas virtuais, 2018. Disponível em: <https://coinmap.org/\#/world/50.06419174/14.58984375/2>. Acesso em: 8 set. 2018.

COMITÊ GESTOR DA INTERNET. Pesquisa sobre o setor de provimento de serviços de internet no Brasil - TIC Provedores 2014. NIC.BR/ CETIC.BR, 2016. Disponível em: $<$ http://www.cgi.br/publicacao/pesquisa-sobre-o-setor-de-provimento- de-servicos-deinternet-no-brasil/>. Acesso em: 11 ago. 2016. 
COMITÊ GESTOR DA INTERNET. Pesquisa sobre o uso das tecnologias de informação e comunicação nos domicílios brasileiros - TIC Domicílios 2014. NIC.BR/CETIC.BR, 2015. Disponível em: <http://www.cgi.br/publicacao/pesquisa-sobre-o-uso-dastecnologias-de- informacao-e-comunicacao-nos-domicilios-brasileiros/ $>$. Acesso em: 11 ago. 2017.

CONTEL, F. B. Redes urbanas e mundialização financeira: atores, normas e financeirização do território brasileiro. In: XIV Encontro Nacional da ANPUR, 2011, Rio de Janeiro. XIV Encontro Nacional da ANPUR, 2011a.

CONTEL, F. B. Território e finanças. Técnicas, normas e topologias bancárias no Brasil. 1. ed. São Paulo: Annablume, 2011b.

CONTEL, F. B. Nova topologia bancária e a geografia urbana brasileira: a hipercapilaridade do crédito. In: ENCUENTRO DE GEÓGRAFOS DE AMÉRICA LATINA - EGAL, $2009 . \quad$ Disponível em: $<$ http://www.observatoriogeograficoamericalatina.org.mx/egal12/Geografiasocioecon omica/Geografiaurbana/43.pdf >. Acesso em: 11 jul. 2018.

CONVERGÊNCIA DIGITAL. 4G dispara em acessos, mas está presente em 9,6\% dos municípios, jul. 2016. Disponível em: $<$ http://convergenciadigital.uol.com.br/cgi/cgilua.exe/sys/start.htm?UserActiveTempla $\mathrm{t} \mathrm{e}=$ site\&infoid=42985\&sid=17\#.V5aPmpOAOkp $>$. Acesso em: 25 jul. 2016.

CONVERGÊNCIA DIGITAL. Google: Brasil é o hub da mega rede de fibra óptica submarina do Google na região, dez. 2015. Disponível em: $<$ http://convergenciadigital.uol.com.br/cgi/cgilua.exe/sys/start.htm?UserActiveTempla $\mathrm{t} \mathrm{e}=$ site\&infoid=41077>. Acesso em: 23 jul. 2017.

CORDEIRO, H. K. Os principais pontos de controle da economia transnacional no espaço brasileiro. Boletim de Geografia Teorética, v. 16-17, n. 31-34, p. 153-196, 1986-87.

CORRÊA, L. R. Processos, formas e interações espaciais. Revista Brasileira de Geografia, Rio de Janeiro, v. 61, n. 1, p. 127-143, jan//jun. 2016.

CORREAA, L. R. Estudos sobre a rede urbana. Rio de Janeiro: Bertrand Brasil, 2006.

CORREAA, L. R. Trajetórias geográficas. 2. ed. Rio de Janeiro: Bertrand Brasil, 2001.

CORRÊA, L. R. Interações espaciais. In: CASTRO, I. E.; GOMES, P. C. C.; CORRÊA, R. L. (Org.). Explorações geográficas. Rio de Janeiro: Bertrand Brasil, 1997. p. 279-318.

CORRÊA, M. B. Tecnologia. In: CATTANI, A. D. (Org.) Trabalho e tecnologia: dicionário crítico. Petrópolis, RJ: Vozes, 1997. p. 250-257.

CORSANI, A. Elementos de uma ruptura: a hipótese do capitalismo cognitivo. In: GALVÃO, A.; SILVA, G.; COCCO, G. Capitalismo cognitivo. Rio de Janeiro: DP\&A, 2003. p. $15-32$.

COUTINHO, E. G. A comunicação do oprimido e outros ensaios. Rio de Janeiro: Mórula, 2014. 
COUTINHO, E. G. (Org.). Comunicação e contra-hegemonia: processos culturais e comunicacionais de contestação, pressão e resistência. Rio de Janeiro: UFRJ, 2008.

CURIEN, N.; GENSOLLEN, M. Réseaux de télécommunications et aménagement de l'espace. Révue Géographique de l'Est, n. 1, p. 47-53, 1985.

DANTAS, M. A lógica do capitalismo-informação: fragmentação dos monopólios e monopolização dos fragmentos num mundo de comunicações globais. Comunicação \& Política, v. III, n. 1, p. 34-57, 1996.

DATAFOLHA. Eleitores de Bolsonaro são os que mais usam as redes sociais, 2018. Disponível em: $\quad<$ https://www1.folha.uol.com.br/poder/2018/10/eleitores-debolsonaro-sao-os-que-mais-usam-as-redes-sociais.shtml>. Acesso em: 4 out. 2018.

DELEUZE, G. O que é um dispositivo, 2011. Disponível em: <https://goo.gl/RFQpX4>. Acesso em: 20 set. 2017.

DELEUZE, G. Post-scriptum sobre as sociedades de controle. São Paulo: Editora 34, 1992.

DIAS, L. C. Os sentidos da rede: notas para discussão. In: DIAS, L. C.; SILVEIRA, R. L. L. (Org.). Redes, sociedade e território. Santa Cruz do Sul, RS: Ed. Unisc, 2005. p. 1128.

DIAS, L. C. Genès et critique de la notion de réseau. In: PARROCHIA, D. (Org.). Penser les réseaux. Seyssel, FR: Champ Vallon, 2001. p. 194-217.

DIAS, L. C. Redes eletrônicas e novas dinâmicas do território brasileiro. In: CASTRO, I. E.; GOMES, P. C. C; CORREAA, R. L. (Org.). Brasil: questões atuais da reorganização do território. Rio de Janeiro: Bertrand Brasil, 1996a. p. 115-144.

DIAS, L. C. Redes geográficas nacionais e internacionais. In: ENCONTRO NACIONAL DE PRODUTORES E USUÁRIOS DE INFORMAÇÕES SOCIAIS, ECONÔMICAS E TERRITORIAIS, maio 1996, Rio de Janeiro: IBGE. Anais... Rio de Janeiro, 1996b. p. $1-11$.

DIAS, L. C. Redes: emergência e organização. In: CASTRO, I. E.; GOMES, P. C.; CORREAA, R. L. (Org.). Geografia: conceitos e temas. Rio de Janeiro: Bertrand Brasil, 1995a. p. 141-162.

DIAS, L. C. Réseaux d'information et réseau urbain au Brésil. Paris: L’Harmattan, 1995b.

DIAS, L. C.; SILVEIRA, R. L. L. (Org.) Redes, sociedades e territórios. Santa Cruz do Sul, RS: Ed. Unisc, 2005.

DICIONÁRIO DE CIÊNCIAS SOCIAIS. Fundação Getúlio Vargas. Instituto de documentação Benedicto Silva. Coordenação geral Antônio Garcia de Miranda Netto et. al. Rio de Janeiro. Ed. Fundação Getúlio Vargas, 1996.

DOMÈNECH, R. B. Redes de Ciudades y externalidades. Revista Investigaciones Regionales, Alcalá de Henares, ES, n. 4, p. 5-27, 2002. 
DORFMAN, A. As escalas do território e sua articulação: uma revisão. In: MESQUITA, Z.; BRANDÃO, C. R. (Org) Territórios do cotidiano: uma introdução a novos olhares e experiências. Porto Alegre, Ed. Unisc, 1995. p. 104-116.

DOSSE, F. O império dos sentidos: a humanização das ciências humanas. Bauru, SP: Edusc, 2003.

DREIFUSS, R. A. Conferência: heterarquia político-estratégica e heterotopia tecnoprodutiva. Ensaios FEE, Porto Alegre, v. 17, n. 2, p. 22-33, 1996.

DUARTE, F.; FREY, K. Redes urbanas. In: DUARTE, F.; QUANDT, C.; SOUZA, Q. (Org.). O tempo das redes. São Paulo: Perspectiva, 2008. p. 155-178.

DUNLOP, J. Les 100 mots de la géographie. Paris: Presses Universitaires de France, 2010.

DUPUY, G. Les effets spatiaux des techniques de télécommunication: ouvrons la boîte noire. Bulletin de l'Isate, n. 17, p. 77-83, jul. 1982.

ELLUL, J. La technique ou L'Enjeu du siècle. Paris: Armand Colin, 1954.

FARIAS, A. R.; MINGOTI, R.; VALLE, L. B.; SPADOTTO, C. A.; LOVISI FILHO, E. Identificação, mapeamento e quantificação das áreas urbanas do Brasil. Embrapa Gestão Territorial, 2017. Disponível em: <https://www.embrapa.br/busca-depublicacoes/-/publicacao/1069928/identificacao-mapeamento-e-quantificacao-dasareas-urbanas-do-brasil>. Acesso em: 9 out. 2018.

FARKAS, J.; BASTOS, M. State propaganda in the age of social media: Examining strategies of the Internet Research Agency. In: EUROPEAN COMMUNICATION CONFERENCE - ECC, 7., 2018, Suíça. Disponível em: $<$ http://muep.mau.se/handle/2043/26724>. Acesso em: 8 nov. 2018.

FGV. FUNDAÇÃO GETÚlIO VARGAS. Pesquisa anual do uso de TI nas empresas. 29. ed. São Paulo: GVcia-EAESP-FGV-EAES8, 2018. Disponível em: $<$ https://eaesp.fgv.br/ensinoeconhecimento/centros/cia/pesquisa $>$. Acesso em: 10 out. 2018.

FINCEN. FINANCIAL CRIMES ENFORCEMENT NETWORK. Application of Fin- CEN's Regulations to Virtual Currency Mining Operations, 30 jan. 2014. Disponível em: https://www. ncen.gov/sites/default/ les/administrative_ruling/FIN-2014-R001>. Acesso em: 8 abril 2018.

FLUSSER, V. O universo das imagens técnicas: elogio da superficialidade. São Paulo: Annablume, 2008.

FLUSSER, V. Filosofia da caixa preta: ensaios para uma futura filosofia da fotografia. São Paulo: Hucitec, 1985.

FORTUNE. Here are the fortune 500's 10 most valuable companies, maio 2018. Disponível em: $\quad<$ http://fortune.com/2018/05/21/fortune-500-most-valuable-companies-2018/>. Acesso em: 20 jul. 2018. 
FOUCAULT, M. Em defesa da sociedade. (Curso no College de France - 1975-1976). 2. ed. São Paulo: Martins Fontes, 2010.

FOUCAULT, M. Nascimento da biopolítica. (Curso no College de France - 1978-1979. São Paulo: Martins Fontes, 2008a.

FOUCAULT, M. Segurança, território, população. (Curso no College de France - 19771978. São Paulo: Martins Fontes, 2008b.

FOUCAUlT, M. Microfísica do Poder. Org. Roberto Machado. Rio de Janeiro: Graal, 1996.

FOUCAULT, M. O sujeito e o poder. In: DREYFUS, H. L.; RABINOW, P. Michel Foucault - Uma trajetória filosófica: para além do estruturalismo e da hermenêutica. Rio de Janeiro: Forense Universitária, 1995. p. 231-249.

FREDERICO, S.; CASTILLO, R. A. Sistema de movimentos no território brasileiro: os novos circuitos espaciais produtivos da soja. In: ENCONTRO NACIONAL DA ANPEGE, 5., 2003, Florianópolis. Anais... Florianópolis, 2003. p. 28-40.

GALVÃO, A. C. F.; BRANDÃO, C. A. Fundamentos, motivações e limitações da proposta governamental dos "Eixos Nacionais de Integração e Desenvolvimento". In: GONÇALVES, M. F.; BRANDÃO, C. A.; GALVÃO, A. C. F. (Org.). Regiões e cidades, cidades nas regiões: o desafio urbano-regional. São Paulo: Ed. Unesp/Anpur, 2003. p. 187-205

GARCIA, R. T. Na nova lei antiterrorismo, seus likes podem levar você para a cadeia. The Intercept Brasil, 2018. Disponível em: <https://theintercept.com/2018/11/07/leiantiterrorismo/?fbclid=IwAR0V988APRarTdtF_gHUzQNteWOSaXaJ_6b79X4IfED H00XcywsNJWB3vWc>. Acesso em: 8 nov. 2018.

GARGAZ, Z. How internet works $<$ I think $>$, 2011. Disponível em: $<$ http://gargasz.info/how_internet_works_i_think.pdf $>$. Acesso em: 10 set. 2018.

GETSCHKO, D. Diálogo Brasil debate a limitação à banda larga fixa. Canal Brasil, 2017. Disponível em: <https://www.youtube.com/watch?v=K-Jfd1VwJ9E>. Acesso em: 12 set. 2017.

GIDDENS, A. As conseqüências da modernidade. São Paulo: Ed. Unesp, 1991.

GILLESPIE, T. The relevance of algorithms. In: GILLESPIE, T.; BOCZKOWSKI, P. J.; FOOT, K. A. Media technologies: essays on communication, materiality and society. Cambridge, MA: The MIT Press, 2014.

GOMES, P. G. Midiatização: um conceito, múltiplas vozes. Revista Famecos - Mídia, Cultura e Tecnologia. Porto Alegre, v. 23, n. 2, maio/ago. 2016. Disponível em: $<$ http://revistaseletronicas.pucrs.br/ojs/index.php/revistafamecos/article/viewFile/2225 3/14176>. Acesso em: 11 ago. 2018.

GONÇALVES, M. E. Direito da informação. Lisboa: Almedina, 2011. 
GOOGLE. Tendências de consumo: Entenda as mudanças no comportamento do consumidor e descubra insights valiosos para sua estratégia. Think with Google, 2018. Disponível em: <https://www.thinkwithgoogle.com/intl/pt-br/tendencias-de-consumo/>. Acesso em: 12 ago. 2018.

GRAGNANI, J. Como planos de celular com Facebook e WhatsApp ilimitados podem potencializar propagação de notícias falsas. BBC News Brasil, 2018. Disponível em: $<$ https://www.bbc.com/portuguese/brasil-43715049>. Acesso em: 3 nov. 2018.

GRAGNANI, J. Exclusivo: investigação revela exército de perfis falsos usados para influenciar eleições no Brasil. BBC News Brasil, 2017. Disponível em: $<$ https://www.bbc.com/portuguese/brasil42172146?fbclid=IwAR2GXp4fvc6ckpz5B_ekPGRevWpEiPzkA4pcfKykWt1eWPX 8vez4CGkhAiQ>. Acesso em: 10 jan. 2018.

GROSSMAN, L. O. Pequenos provedores puxam mercado e banda larga fixa cresce 7,15\% em 2017. Convergência Digital, 31 jan. 2018. Disponível em: $<$ http://www.convergenciadigital.com.br/cgi/cgilua.exe/sys/start.htm?UserActiveTem plate $=$ site \&infoid $=47167 \&$ sid $=4>$. Acesso em: 12 fev. 2018 .

GSMA. The mobily economy, 2018. Disponível em: $<$ https://www.gsma.com/mobileeconomywp-content/uploads/2018/05/The-MobileEconomy-2018.pdf>. Acesso em: 11 set. 2018.

HAESBAERT, R. O mito da desterritorialização: do "fim dos territórios" à multiterritorialidade. Rio de Janeiro: Bertrand Brasil, 2004.

HAESBAERT, R. Concepções de território para a entender a desterritorialização. In: PPGGUFF. Território, territórios. Niterói, RJ: PPGEO-UFF/AGB-Niterói, 2002. p.17-38.

HAESBAERT, R. Desterritorialização: entre as redes e os aglomerados de exclusão. In: CASTRO, I. E.; GOMES, P. C. C.; CORRÊA, R. L. Geografia: conceitos e temas. Rio de Janeiro: Bertrand Brasil, 1995. p. 165-205.

HARARI, Y. N. Why technology favors tyranny. The Atlantic, Oct. 2018. Disponível em: $<$ https://bit.ly/2T9V6RE $>$. Acesso em: 12 nov. 2018.

HARVEY, D. Espaços da esperança. São Paulo: Loyola, 2004.

HARVEY, D. A condição pós-moderna. São Paulo: Loyola, 1992.

HILBERT, M. Despreparada para a era digital, a democracia está sendo destruída, afirma guru da big data. BBC News Brasil, 2018. Disponível em: $<$ https://www.bbc.com/portuguese/geral-

39535650?SThisFB\&fbclid=IwAR0Lh14rf9ja19H_Rqu47xwZcwD10j4QnEDvRhvmB xs0EPzt1B3ZIwIi7rA>. Acesso em: 7 jun. 2018.

HIRST, P.; THOMPSON, G. Globalização em questão: a economia internacional e as possibilidades de governabilidade. Petrópolis, RJ: Vozes, 1998. 
HOBDAY, M. The brazilian telecommunications industry: accumulation of microeletronic technology in the manufacturing and service sectors. Rio de Janeiro: UFRJ/IEL, 1984. Mimeo.

IBGE. INSTITUTO BRASILEIRO DE GEOGRAFIA E ESTATÍSTICA. Estimativas da população residente para os municípios e para as unidades da federação com data de referência em $1^{\text {o }}$ de julho de 2018, 2018a. Disponível em: $<$ https://biblioteca.ibge.gov.br/index.php/biblioteca-

catalogo?view=detalhes\&id=2101597>. Acesso em: 15 out. 2018.

IBGE. INSTITUTO BRASILEIRO DE GEOGRAFIA E ESTATÍSTICA. Pesquisa Nacional por Amostra de Domicílios Contínua - PNAD Contínua - Educação. Diretoria de Pesquisas, Coordenação de Trabalho e Rendimento, Pesquisa Nacional por Amostra de Domicílios Contínua 2016-2017, 2018b. Disponível em: $<$ https://biblioteca.ibge.gov.br/visualizacao/livros/liv101576_informativo.pdf $>$. Acesso em: 12 ago. 2018.

IBGE. INSTITUTO BRASILEIRO DE GEOGRAFIA E ESTATÍSTICA. Classificação e caracterização dos espaços rurais e urbanos do Brasil, 2017. Disponível em: $<$ https://ww2.ibge.gov.br/home/geociencias/geografia/espacos_rurais_e_urbanos/defa ult.shtm>. Acesso em: 9 out. 2018.

IBGE. INSTITUTO BRASILEIRO DE GEOGRAFIA E ESTATÍSTICA. Arranjos populacionais e concentrações urbanas no Brasil. Coordenação de Geografia. 2. ed. Rio de Janeiro: IBGE, 2016a. Disponível em: $<$ https://www.ibge.gov.br/apps/arranjos_populacionais/2015/pdf/publicacao.pdf $>$. Acesso em: 12 jan. 2017.

IBGE. INSTITUTO BRASILEIRO DE GEOGRAFIA E ESTATÍSTICA. Pesquisa Nacional por Amostra de Domicílios Contínua (PNAD). Acesso à internet e à televisão e posse de telefone móvel celular para uso pessoal. Coordenação de Trabalho e Rendimento. Rio de Janeiro: IBGE, 2016b. Disponível em: <http://biblioteca.ibge.gov.br/ visualizacao/livros/liv95753.pdf>. Acesso em: 21 jul. 2016.

IBGE. INSTITUTO BRASILEIRO DE GEOGRAFIA E ESTATÍSTICA. Perfil dos estados e municípios brasileiros. Coordenação de População e Indicadores Sociais. Rio de Janeiro, 2015. Disponível em: $<$ https://biblioteca.ibge.gov.br/visualizacao/livros/liv94541.pdf $>$. Acesso em: 12 mar. 2018.

IGARAPÉ INSTITUT. Cabos transatlânticos brasileiros, 2018. Disponível em: $<$ https://igarape.org.br/marcocivil/pt/>. Acesso em: 27 out. 2018.

INAF Brasil 2018. Pesquisa gera conhecimento: o conhecimento se transforma, 2018. Disponível em: <http://acaoeducativa.org.br/wpcontent/uploads/2018/08/Inaf2018_Relatório-ResultadosPreliminares_v08Ago2018.pdf>. Acesso em: 8 out. 2018.

INPE. INSTITUTO NACIONAL DE PESQUISAS ESPACIAIS. O que é a ionosfera? Portal de acesso à informação, transparência, participação e colaboração, 2018. Disponível em: <http://www.inpe.br/acessoainformacao/node/448>. Acesso em: 22 ago. 2018. 
INTERNET.ORG. Connecting the world. Disponível em: <https://info.internet.org/en/>. Acesso em: 24 jul. 2016.

INTERVOZES. Coletivo Brasil de Comunicação Social: sistemas públicos de comunicação no mundo: experiência de doze países e o caso brasileiro. São Paulo: Paulus, 2009.

INTRONA, L. Otherness and the letting-be of becoming: or, ethics beyond bifurcation. In: CARLILE, P.; NICOLINI, D.; LANGLEY, A.; TSOUKAS, H. (Ed.). How matter matters. Oxford: Oxford University Press, 2013.

ISO. INTERNATIONAL ORGANIZATION fOR STANDARDIZATION. About ISO, 2018. Disponível em: <https://www.iso.org/about-us.html>. Acesso em: 25 out. 2018.

JACKS, N.; TOALDO, M. M. (Org.). Brasil em números: dados para pesquisas de comunicação e cultura em contextos regionais. Florianópolis: Insular, 2014.

JACOBS, J. The economy of cities. New York: Random House, 1969.

JENKINS, H. Cultura da convergência. 2. ed. São Paulo: Aleph, 2009.

JENKINS, H. Confronting the challenges of participatory culture: media education for the 21st Century. Cambridge, MA/London: The MIT Press, 2006. Disponível em: $<$ http://www.newmedialiteracies.org/wp-content/uploads/pdfs/NMLWhitePaper.pdf $>$. Acesso em: 20 jul. 2016.

JOHNSTON, R. J.; GREGORY, D.; SMITH, D. M. The Dictionary of Human Geography. 3rd ed. Cambrige, MA: Blackwell Publishers, 1994.

JUBE, A. Brasil é $1^{\circ}$ caso de fake news maciça para influenciar votos, diz OEA. Valor Econômico, out. 2018. Disponível em: $<$ https://www.valor.com.br/politica/5948635/brasil-e-1-caso-de-fake-news-macicapara-influenciar-votos-diz-oea?fbclid=IwAR2CqJ1E06kbKgvXtRFJ35MY1FHOpkVs1z-HM2uQMpadOcf-4uheP8JQqQ>. Acesso em: 26 out. 2018.

KENNEY, M.; ZYSMAN, J. The rise of the platform economy. Issues in Science and Technology, v. 32, n. 3, p. 61-69, Mar. 2016. Disponível em: $<$ http://issues.org/323/the-rise-of-the-platform-economy/>. Acesso em: 16 ago. 2018.

KUROSE, J. F.; ROSS, K. W. Redes de computadores e a internet. São Paulo: Addison Wesley, 2010.

LATOUR, B. Políticas da natureza: como fazer ciência na democracia. Bauru, SP: Edusc, 2004.

LATOUR, B. A esperança de Pandora: ensaios sobre a realidade dos estudos científicos. Bauru, SP: Edusc, 2001.

LATOUR, B. Jamais fomos modernos: ensaio de antropologia simétrica. Rio de Janeiro: Editora 34, 1994.

LAZZARATO, M. As revoluções do capitalismo. Rio de Janeiro: Civilização Brasileira, 2006. 
LE GOFF, J. A história deve ser dividida em pedaços? São Paulo: Ed. Unesp, 2015.

LENCIONI, S. Da cidade e sua região à cidade-região. In: SILVA, J. B; LIMA, L. C; ELIAS, D. (Org.) Panorama da geografia brasileira I. São Paulo: Anablume, 2006. v. 1. p. $65-76$

LÉVY, P. Cibercultura. Tradução Carlos Irineu da Costa. São Paulo: Editora 34, 2000.

LÉVY, P. O que é virtual? São Paulo: Editora 34, 1996.

LÉVY, P. As tecnologias da inteligência: o futuro do pensamento na era da informática. Rio de Janeiro: Editora 34, 1993.

LIEM, C.; PETROPOULOS, G. The economic value of personal data for online platforms, firms and consumers. Brugel, Jan. 2016. Disponível em: $<\mathrm{http}$ ://bruegel.org/2016/01/the-economic-value-of-personal-data-for-onlineplatforms-firms-and-consumers/ >. Acesso em: 12 jna. 2018.

LOJKINE, J. A revolução informacional. São Paulo: Cortez, 1995.

LUDWIG, M. J. Identificação computacional de emoções negativas em textos da internet: proposta de apoio ao usuário para controle emotivo. Monografia (Bacharelado em Engenharia da Computação) - Instituto de Engenharia da Computação, Universidade do Vale do Taquari, Lajeado, RS, 2018.

MAGALHÃES, H. Prestadoras de nicho avançam no país. Valor Econômico, 7 nov. 2017. Disponível em: <http://www.valor.com.br/empresas/5184081/prestadoras-de-nichoavancam-no-pais $>$. Acesso em: 12 jan. 2018.

MAIN, D. Undersea cables transport 99 percent of international data. Newsweek, 2 Apr. 2015. Disponível em: <https://www.newsweek.com/undersea-cables-transport-99percent-international-communications-319072>. Acesso em: 19 jul. 2016.

MAPBOX. Mobile devices + twitter users. Disponível em: $<$ https://www.mapbox.com/labs/twitter-gnip/brands/\#11/-23.5816/-46.5915 http://super.abril.com.br/tecnologia/mapas-mostram-concentracao-de-iphones-e-deaparelhos-com-android-em-cidades-mundo-afora>. Acesso em: 19 jul. 2016.

MARCUSE, H. A ideologia da sociedade industrial: o homem unidimensional. Rio de Janeiro: Zahar, 1982.

MATTELART, A. A globalização da comunicação. 2. ed. Bauru, SP: Edusc, 2002.

MATTElarT, A. Agresión desde el espacio: cultura napalm en la era de los satélites. Buenos Aires: Siglo Veintiuno, 1973.

MATTELART, A.; SCHMUCLER, H. L'ordinateur et le tiers monde: l'Amérique latine à l'heure des choix télématiques. Paris: François Maspero, 1983. (Collection Cahiers Libres.)

MAZZUCATO, M. O Estado empreendedor: desmascarando o mito do setor público vs. setor privado. São Paulo: Portfolio-Penguin, 2014. 
MCLUHAN, M. Os Meios de Comunicação como Extensões do Homem (Understanding Media). $12^{\mathrm{a}}$ ed. São Paulo: Cultrix, 2002.

MCLUHAN, M. Processo decisório no setor de telecomunicações. Dissertação (Mestrado) - Instituto Universitário de Pesquisas do Rio de Janeiro, Rio de Janeiro, 1981.

MCLUHAN, M. La galaxie Gutenberg. Paris, Gallimard, 1977.

MENDONÇA, R. Fake news anti-PT alcançam um terço do eleitorado. Valor Econômico, 2018. Disponível em: <https://www.valor.com.br/politica/5950237/fake-news-anti-ptalcancam-um-terco-do-eleitorado>. Acesso em: 28 out. 2018.

MÉO, G. Introdução ao debate sobre a metropolização, Confins [Online], 2008. Disponível em: <http://journals.openedition.org/confins/5433>. Acesso em: 10 fev. 2016.

MICROSOFT. O que é nuvem? Definição de Nuvem, 2018. Disponível em: $<$ https://azure.microsoft.com/pt-br/overview/what-is-the-cloud/>. Acesso em: 27 ago. 2018.

MINISTÉRIO DAS CIÊNCIAS E TECNOLOGIA INOVAÇÕES E COMUNICAÇÕES. Estratégia brasileira para a transformação digital. Brasília, 2018. Disponível em: $<$ http://www.mctic.gov.br/mctic/export/sites/institucional/estrategiadigital.pdf $>$. Acesso em: 28 set 2018.

MINISTÉRIO DO PLANEJAMENTO, DESENVOLVIMENTO E GESTÃO. Cidades Digitais investe R\$ 201,7 milhões em tecnologia, 2013. Disponível em: $<$ http://www.planejamento.gov.br/assuntos/investimento-e-pac/noticias/cidadesdigitais-investe-r-201-7-milhoes-em>. Acesso em: 13 set. 2017.

MOBILE NETWORK GUIDE. Mobile industry news, 2018. Disponível em: $<$ http://www.mobilenetworkguide.com>. Acesso em: 12 out. 2018.

MOLES, A. A. Teoria da complexidade e civilização industrial. In: MOLES, A. A. et al. Civilização industrial e cultura de massas. Petrópolis, RJ: Vozes, 1973. p. 7-27.

MOLES, A. A. Teoria da informação e percepção estética. Rio de Janeiro: Tempo Brasileiro, 1969.

MORAES, A; COSTA, W. M. Geografia crítica: a valorização do espaço. 2. ed. São Paulo: Hucitec, 1987.

MORAES, M. A ciência como rede de atores: ressonâncias filosóficas. História, Ciências, Saúde - Manguinhos, , Rio de Janeiro, v. 11, n. 2, p. 321-33, 2004.

MOROZOV, E. Como a dependência tecnológica ameaça a democracia. Nexo Jornal, 2018. Disponível em: <https://bit.ly/2FwiJkC>. Acesso em: 28 out. 2018.

MURRAY, J. Hamlet no Holodeck: o futuro da narrativa no ciberespaço. Tradução Elissa Khoru Daher; Marcelo Fernandez Cuzziol. São Paulo: Itaú Cultural/Unesp, 2003. 
MUSEU DAS COMUNICAÇÕES. Envio de Informação através de Feixes de Luz, 2018. Disponível em: $\quad<$ http://www.cmm.gov.mo/por/exhibition/secondfloor/ MoreInfo/2_8_1_LightBeams.html>. Acesso em: 22 ago. 2018.

MUSSO, P. Critique des réseaux. Paris: PUF, 2003.

MUSSO, P. Genès et critique de la notion de réseau. In: PARROCHIA, D. (Org.). Penser les réseaux. Seyssel, FR: Champ Vallon, 2001. p. 194-217.

NARAYANAN, A.; SHMATIKOV, V. Myths and fallacies of personally identifiable information. Communications of the ACM, v. 53, n. 6, p. 24-26, 2010. Disponível em: <https://www.cs.utexas.edu/ shmat/shmat_cacm10.pdf $>$. Acesso em: 13 set 2017.

NEC CORPORATION. NEC dá início à construção do sistema de cabos do Atlântico Sul, 2018. Disponível em: <https://br.nec.com/pt_BR/press/ PR/20160413045016_3028.html>. Acesso em: 13 set. 2018.

NEVES, J. P. Seres humanos e objetos técnicos: a noção de "concretização" em Gilbert Simondon. Comunicação e Sociedade, v. 12, p. 67-82, 2007. Disponível em: $<$ http://revistacomsoc.pt/index.php/comsoc/article/view/1097/1051>. Acesso em: 22 mar. 2018.

NORBERT, W. Cibernética e sociedade. São Paulo: Cultrix, 1968.

NORMAN, D. A. The design of everyday things. New York: Basic Books, 1988.

NOVAES, A. Privatização no setor de telecomunicações no Brasil. In: PINHEIRO, A. C.; FUKASAKU, K. A privatização no Brasil: o caso dos serviços de utilidade pública. Brasília: BNDES, 2000. p. 54-82.

OECD. ORGANIZAÇÃO PARA A COOPERAÇÃO E DESENVOLVIMENTO ECONÔMICO. Exploring the Economics of Personal Data: A Survey of Methodologies for Measuring Monetary Value. OECD Digital Economy Papers, Paris: OECD Publishing, n. 220, 2003. Disponível em: $<\mathrm{http}: / /$ dx.doi.org/10.1787/5k486qtxldmq-en>. Acesso em: 13 set 2017.

OFFNER, J.-M. Territorial deregulation: Local authorities at risk from technical networks. International Journal of Urban and Regional Research, v. 24, n. 1, p. 165-182, Mar. 2000.

OFFNER, J.-M.; PUMAIN, D. Réseaux et territoires: significations croisées. Paris: Ed. de l'Aube, 1996.

OFFNER, J.-M. Les effets structurants du transport: mythe politique, mystification scientifique. L'Espace Géographique, n. 3, p. 233-242, 1993.

OLEGÁRIO, R. Credit reporting agencies: a historical perspective. Cambridge, MA: The MIT Press, 2002.

OPEN SIGNAL. Mobile Networks Update: Brazil, 2018. Disponível em: $<$ https://opensignal.com/reports-data/update/data-2018-06-brazil/report.pdf $>$. Acesso em: 30 set. 2018. 
ORACLE. Oracle buys Bluekay. Disponível em: $<$ https://www.oracle.com/corporate/acquisitions/bluekai/index.html $>$. Acesso em: 13 set. 2017.

PARROCHIA, D. Philosophie des réseaux. Paris: Presses Universitaires de France, 1993.

PEREIRA, S.; BIONDI, A. (Org.). Caminhos para a universalização da internet banda larga: experiências internacionais e desafios brasileiros. São Paulo: Intervozes, 2012.

PIORE, M. Inovações tecnológicas e o impacto sobre a cidade. Espaço \& Debates, São Paulo: Neru, v. 7, n. 21, p. 5-7, 1987.

PIRES, H. F. Bitcoin: a moeda do ciberespaço. Geousp - Espaço e Tempo (Online), v. 21, n. 2, p. 407-424, ago. 2017.

POCHMANN, M. Terceirização, competitividade e uberização do trabalho no Brasil. In: TEIXEIRA, M. O.; RODRIGUES, H.; COELHO, E. A. (Ors.). Precarização e terceirização: faces da mesma realidade. São Paulo: Sindicato dos Químicos, 2016. p. 59-68.

POLANYI, M. Personal knowledge. London: Routledge \& Kegan, 1958.

POOL, I. S. Os efeitos sociais do telefone. In: CLARKE, A. C.; DERTOUZOS, M. L.; HALLE, M.; POOL, I. S.; WIESNER, J. B. O telefone: ontem, hoje e amanhã. Brasília, DF: Telebrás, 1979. p. 9-20.

PORTAL BRASIL. Defesa e segurança: comunicação via satélite encurta distâncias no Amazonas, 2 nov. 2015. Disponível em: <http://www.brasil.gov.br/defesa-eseguranca/2015/03/comunicacao-via-satelite-encurta-distancias-no-amazonas $>$.

Acesso em: 4 jul. 2016.

PRESIDÊNCIA DA REPÚBLICA. Lei Geral das Telecomunicações n 9.472, de 16 de julho de 1997. Casa Civil - Subchefia para assuntos jurídicos. Disponível em

http://www.planalto.gov.br/ccivil_03/LEIS/L9472.htm Acesso em 3 abr. 2019.

PROJETO LOON. Internet por balão para todos. Disponível em: $<$ https://www.google.com/intl/pt-BR/loon/>. Acesso em: 24 jul. 2016.

RAFFESTIN, C. Por uma geografia do poder. São Paulo: Ática, 1993.

RAFFESTIN, C. Marxismo y geografía política. In: GARCÍA BALLESTEROS, A. (Coord.). Geografías y marxismo. Madrid: Editorial de la Universidad Complutense, 1985. p. 279-297.

RANDOLPH, R. A sociedade em rede. Resenha. Revista Brasileira de Estudos Urbanos e Regionais, n. 2, p. 111-113, 2000.

REIS, N. G. Notas sobre a organização das regiões metropolitanas. Cadernos de Pesquisa do LAP, São Paulo: LAP-FAUUSP, n. 11 - Série Urbanização e Urbanismo, 1996.

RIBEIRO, A. Outros territórios, outros mapas. OSAL - Observatorio Social de América Latina, Buenos Aires: Clacso, v. 6, n. 16, jun. 2005. 
RIBEIRO, A. Matéria e espírito: o poder (des)organizador dos meios de comunicação. In: PIQUET, R.; RIBEIRO, A. C. T. (Org.). Brasil: território da desigualdade. Rio de Janeiro: Jorge Zahar/Fundação José Bonifácio, 1991. p. 44-55.

RIBEIRO, C; MERLI, D.; SILVA, S. P. Exclusão digital no Brasil e em países emergentes: um panorama da primeira década do século XXI. In: PEREIRA, S.; BIONDI, A. (Org.). Caminhos para a universalização da internet banda larga: experiências internacionais e desafios brasileiros. São Paulo: Intervozes, 2012. cap. 7, p. 197-222.

RIFKIN, J. A era do acesso. São Paulo: Makron, 2001.

RNP. REDE NACIONAL DE ENSINO E PESQUISA. Sobre a RNP: Mapas de evolução do backbone no Brasil. Rio de Janeiro, 2014. Disponível em: $<$ https://memoria.rnp.br/rnp/backbone-historico-graficos.html/>. Acesso em: 24 jul. 2016.

SÁNCHEZ, J.-E. Espacio, economía y sociedad. Madrid: Siglo Veintiuno, 1991.

SANTANA, M. R. C. O espaço urbano em construção: as redes técnicas na cidade do Salvador do início do século XXI. Tese (Doutorado em Urbanismo) - Faculdade de Arquitetura e Urbanismo, Universidade Federal da Bahia, Salvador, 2006.

SANTOS, M. O trabalho do geógrafo no Terceiro Mundo. 5. ed. São Paulo: Edusp, 2009.

SANTOS, M. Território e dinheiro. In: PPGG- UFF. Território, territórios. Niterói, RJ: PPGEO-UFF/AGB-Niterói, 2002. p. 17-38.

SANTOS, M. Há mesmo um espaço virtual? Palestra proferida em 21 fev. 2000a. Disponível em: $\quad<$ http://reverbe.net/cidades/wp-content/uploads/2011/livros/Ha-mesmo-umespacovirtual_Milton-Santos.pdf>. Acesso em: 11 ago. 2016.

SANTOS, M. Por uma outra globalização: do pensamento único à consciência universal. Rio de Janeiro: Record, 2000b.

SANTOS, M. Da política dos Estados à política das empresas. Cadernos da Escola do Legislativo de Belo Horizonte, v. 3 n. 6, p. 9-23, jan./jun.1998.

SANTOS, M. A natureza do espaço: técnica e tempo, razão e emoção. São Paulo: Hucitec, 1996.

SANTOS, M. Técnica, espaço, tempo: globalização e meio técnico-científico informacional. São Paulo: Hucitec, 1994.

SANTOS, M. Modernidade, meio técnico científico e urbanização no Brasil. Cadernos IPPUR, Rio de Janeiro: UFRJ, v. 1, n. 9, p. 22, 1992.

SANTOS, M. O meio técnico-científico e a urbanização no Brasil. In: SEMINÁRIO BRASIL SÉCULO XXI, Seção Campo e Cidade na Virada do Século. Universidade Estadual de Campinas, 4 abr. $1989 . \quad$ Disponível em: $<$ http://www.cmu.unicamp.br/seer/index.php/resgate/article/view/36/41>. Acesso em: 20 jul. 2016. 
SANTOS, M. O meio técnico-científico e a urbanização no Brasil. Espaço \& Debates, n. 25, p. 58-62, 1988.

SANTOS, M. Sociedade e espaço: a formação social como teoria e como método. Boletim Paulista de Geografia - BPG, n. 54, p. 81-100, 1977.

SANTOS, M.; SILVEIRA, M. L. O Brasil: território e sociedade no início do século XXI. Record: Rio de Janeiro, 2002.

SASSEN, S. As cidades na economia mundial. São Paulo: Studio Nobel, 1998.

SCHNEIER, B. A taxonomy of social networking data, 2009. Disponível em: $<\mathrm{https} / / /$ www.schneier.com/blog/archives/2009/11/a_taxonomy_of_s.html $>$. Acesso em: 13 set 2017.

SCRUTON, R. The palgrave Macmillan dictionary of political thought. 3rd ed. New York: Palgrave Macmillan, 2007.

SENADO NOTÍCIAS. Lei Antiterrorismo. Senado Federal, 2018. Disponível em: $<$ https://www12.senado.leg.br/noticias/tags/Lei\%20Antiterrorismo $>$. Acesso em: 20 nov. 2018.

SERASA EXPERIAN. Mosaic, 2018. Disponível em: $<$ https://marketing.serasaexperian.com.br/targeting/mosaic/?gclid=Cj0KCQiAq6_UB RCEARIsAHyrgUxAhwZp_tC3wmbLeSBjQP3bzcSrIHv8VXm3jvOpmXu4Je7ĀpAv IV_saAvQuEALw_wcB>. Acesso em: 18 set. 2018.

SFEZ, L. Télévision e réalité. In: COURBET D.; FOURQUET-COURBET, M.-P. (Dir.). La télévision et ses influences. Louvain-la-Neuve, BE: De Boeck Supérieur Éditeur, 2003. cap. 12, p. 143-140.

SFEZ, L. Le réseaux: du concept initial aux technologies de l'esprit contemporaines. In: PARROCHIA, D. (Org.). Penser las réseaux. Seyssel, FR: Champ Vallon, 2001. p. 93-113.

SHAO, S.; CIAMPAGLIA, G. L.; VAROL, O.; YANG, K. C; FLAMMINI, A.; MENCZER, F. The spread of low-credibility content by social bots. Nature Communications, v. 9, n. 4787, 2018. Disponível em: <https://www.nature.com/articles/s41467-01806930-7>. Acesso: em 27 nov. 2018.

SHAPIRO, C.; VARIAN, H. R. A economia da informação. Rio de Janeiro: Elsevier, 2003.

SHEPPARD, E. The spaces and times of globalization: place, space, networks and positionality. Economic Geography, Worcester, MA: Clark University, v. 78, n. 3, p. 307-330, 2002.

SILVA, A. Círculos de informações e novas dinâmicas do território brasileiro. In: ENCONTRO NACIONAL DOS GEÓGRAFOS, 16., 2010, Porto Alegre. Anais... Porto Alegre, 2010. p. 113-131.

SILVA, P. C. A teoria dos dois circuitos da economia urbana e a mídia na contemporaneidade. In: MOREIRA, S. V. M. (Org.). Indústria da comunicação no 
Brasil: dinâmicas da academia e do mercado. Rio de Janeiro: UERJ/Intercom, 2015. p. 29-50.

SILVA, P. F. Geografia das telecomunicações no Brasil. São Paulo: Cultura Acadêmica, 2015.

SILVA, S. Internet em redes de alta velocidade: concepções e fundamentos sobre banda larga. In: PEREIRA, S.; BIONDI, A. (Org.). Caminhos para a universalização da internet banda larga: experiências internacionais e desafios brasileiros. São Paulo: Intervozes, 2012. cap. 1, p. 23-50.

SILVA, V. A ampliação das redes de transporte público no estado de São Paulo: articulações institucionais e usos do território. Dissertação (Mestrado em Geografia) Instituto de Geociências e Ciências Exatas, Universidade Estadual Paulista, Rio Claro, 2017.

SILVEIRA, M. L. Escala geográfica: da ação ao império? Terra Livre, Goiânia, v. 2, n. 23, p. 87-96, jul./dez. 2004.

SILVEIRA, M. L. Totalidade e fragmentação: o espaço global, o lugar e a questão metodológica, um exemplo argentino. In: SANTOS, M.; SOUZA, M. A.; SCARLATO, F. C.; ARROYO, M. (Org.). O novo mapa do mundo: fim de século e globalização. São Paulo: Hucitec/Anpur, 2002a. p. 201-209.

SILVEIRA, M. L. Uma globalização desnecessária, um território instável. Ciência Geográfica, Bauru, v. 1, n. 21, p. 43-46, 2002 b.

SILVEIRA, M. L. Concretude territorial, regulação e densidade normativa. Revista Experimental, São Paulo: Laboplan-DG-FFLCH-USP, n. 02, p. 35-45, mar. 1997.

SILVEIRA, M. R.; COCCO, R. G. Interações espaciais, transporte público e estruturação do espaço urbano. Revista Brasileira de Estudos Urbanos e Regionais, v. 12, n. 1, p. 63-81, maio 2010. Disponível em: $<$ http://rbeur.anpur.org.br/rbeur/article/view/232/216>. Acesso em: 12 abr. 2017.

SILVEIRA, R. L. L. Redes e território: uma breve contribuição geográfica ao debate sobre a relação sociedade e tecnologia. Biblio 3W - Revista Bibliográfica de Geografía y Ciencias Sociales, Barcelona: Universidad de Barcelona, v. VIII, n. 451, 2003. Disponível em: <http://www.ub.es/geocrit/b3w-451.htm>. Acesso em: 12 jun. 2018.

SILVEIRA, S. A. Tudo sobre tod@s: redes digitais, privacidade e venda de dados pessoais. São Paulo: Ed. Sesc, 2017a.

SILVEIRA, S. A. Governo dos algoritmos. Revista de Políticas Públicas, v. 21, n. 1, p. $267-$ 281, 2017b. Disponível em: <http://www.periodicoseletronicos.ufma.br/index.php/ rppublica/article/view/6123>. Acesso em: 22 ago 2018.

SILVEIRA, S. A. Inclusão digital, software livre e globalização contra-hegemônica. In: SEMINÁRIOS TEMÁTICOS PARA A TERCEIRA CONFERÊNCIA NACIONAL DE C,T\&I, 2005. Disponível em: $<$ http://www.softwarelivre.gov.br/artigos/artigo_02/>. Acesso em: 20 jul. 2016. 
SIMET. SISTEMA DE MEDIÇÃO DE TRÁFEGO DE ÚLTIMA MILHA. Avaliador da qualidade da banda larga no Brasil, 2018. Disponível em: <https://simetpublico.ceptro.br/mapas7/>. Acesso em: 12 out. 2018.

SIMONDON, G. El modo de existencia de los objetos técnicos. Buenos Aires: Prometeo, 2007.

SMITH, N. Uneven development: nature, capital and the production of space. Athens/London: The University of Georgia Press, 2008.

SMITH, N. Scale Bending and the Fate of the National. In: SHEPPARD, E.; MCMASTER, R. B. Scale and Geographic Inquiry: Nature, Society, and Method. Malden, USA: Blackwell. 2004. p. 192-212.

SMITH, N. The satanic geographies of globalization: uneven development in the 1990s. Public Culture, v. 10, n. 1, p. 169-189, 1997.

SMITH, N. Contours of a Spatialized Politics: Homeless Vehicles and the Production of Geographical Scale. Social Text, Duke University Press, n. 33, p 54-81, 1992.

SMITH, N. Desenvolvimento desigual: natureza, capital e a produção do espaço. Rio de Janeiro: Bertrand Brasil, 1988.

SOARES, M. T. S. Critérios de delimitação de áreas metropolitanas e a possibilidade de sua aplicação ao Brasil. In: SIMPÓSIO DE GEOGRAFIA URBANA. Comissão de Geografia do Instituto Panamericano de Geografia e História, n. 24, Rio de Janeiro, 1968. p. 91-106.

SODRÉ JR., A. C.; COSTA, I. F.; RAIMUNDO-NETO, E. Uso de tecnologia de rádio sobre fibra ótica pode melhorar distribuição do sinal de internet e telefonia móvel. Ciência Hoje, v. 12, n. 163, p. 50-63, 2012.

SODRÉ JR., A. C.; ROSA, G. S. Na era do wi-fi, a internet ainda depende de cabos para existir. UOL, 18 mar. 2018. Disponível em: $<$ https://noticias.uol.com.br/tecnologia/noticias/redacao/2018/03/18/na-era-do-wi-fi-ainternet-ainda-depende-de-cabos-para-existir.htm>. Aceso em: 16 jun. 2018.

SODRÉ, M. A comunicação do grotesco: um ensaio sobre a cultura de massa no Brasil. 5. ed. Petrópolis, RJ: Vozes, 1976.

SOJA, E. W. Geografia pós-modernas: a reafirmação do espaço na teoria social crítica. Rio de Janeiro: Jorge Zahar, 1993.

SORJ, B. Brasil@povo.com: a luta contra a desigualdade na sociedade da informação. Rio de Janeiro/Brasília, DF: Jorge Zahar/Unesco, 2003.

SOUZA, C. Desafios da internet no debate democrático e nas eleições: discurso de ódio e fake news. Comitê Gestor da Internet no Brasil (CGI.br), 2018. Disponível em: $<$ https://www.youtube.com/watch?v=ceze1ZYEVtw>. Acesso em: 16 jun. 2018. 
SOUZA, M. O território: sobre espaço e poder, autonomia e desenvolvimento. In: CASTRO, I. E.; GOMES, P. C. C.; CORRÊA, R. L. (Org.). Geografia: conceitos e temas. Rio de Janeiro: Bertrand Brasil, 1995. p. 77-116.

SPOSITO, M. E. B. O chão em pedaços: urbanização, economia e cidades no estado de São Paulo. Tese (Livre-docência) - Faculdade de Ciências e Tecnologia, Universidade Estadual Paulist, Presidente Prudente, 2005.

STAROSIELSKI, N. Signal Tracks. Journal of the New Media Caucus, v.10, n. 1, 2014.

STEINBERGER, M.; TOFETI, A. R. A trilogia celular-torre-antena como uma expressão da territorialidade informacional no Brasil. Revista Eletrônica: Tempo - Técnica Território, v. 6, n. 1, p. 73-97, 2015.

SWIFT. The global provider of secure financial messaging services. About us. Disponível em: $<$ https://www.swift.com/about-us $>$. Acesso em: 9 jul. 2018.

SWYNGEDOUW, E. Neither global nor local: "glocalization" and the politics of scale. In: COX, K. (Ed.) Spaces of globalization. New York: Guilford, 1997.

TECMUNDO. Como funciona a fibra ótica, 2018. Disponível em: $<$ https://www.tecmundo.com.br/infografico/9862-como-funciona-a-fibra-oticainfografico-.htm>. Acesso em: 28 jul. 2018.

TELEBRASIL.ASSOCIAÇÃO BRASILEIRA DE TELECOMUNICAÇÕES. Mapas das ERBs Brasil, 2018. Disponível em: <http://www.telebrasil.org.br/panorama-dosetor/mapa-de-erbs-antenas>. Acesso em: 16 nov. 2018.

TELEBRASIL.ASSOCIAÇÃO BRASILEIRA DE TELECOMUNICAÇÕES. Mapa de ERBs Brasil (antenas), [s.d.]. Disponível em: <http://www.telebrasil.org.br/panorama-dosetor/mapa-de- erbs-antenas>. Acesso em 19 jul. 2016.

TELECO. Inteligência em Telecomunicações. Cobertura das operadoras e população atendida, 26 nov. 2018a. Disponível em: <http://www.teleco.com.br/cobertura.asp $>$. Acesso em: 9 set. 2018.

TELECO. Tecnologia em Telecomunicações. Estatísticas de Celulares no Brasil, out. 2018b. Disponível em: <http://www.teleco.com.br/ncel.asp>. Acesso em: 19 jul. 2016.

TELEGEOGRAPHY. Submarine Cable Map, 2018. Disponível em: <https://submarinecable-map-2018.telegeography.com>. Acesso em: 27 out. 2018.

TELESÍNTESE. A "uberização" das redes de telecomunicações, 19 nov. 2018. Disponível em: $\quad<$ http://www.telesintese.com.br/eduardo-grizendi-a-uberizacao-das-redes-detelecomunicacoes/?fbclid=IwAR1 ewPBJ6_ShQbmAcxoDcWVIY8EyuEuOVVtJrnpi TUEsG3f5avnrdxoFJI4>. Acesso em 22 nov. 2018.

THE ATLANTIC CABLE MAPS. Carte générale des grandes communications télégraphiques du monde, 1903. International Telegraph Bureau, Berne, Switzerland. Disponível em: <http://atlantic-cable.com/Maps/>. Acesso em: 1 jul. 2018. 
THE PENGUIN DICTIONARY OF PHYLOSOPHY. 2. ed. [s.1.]: Penguin Reference, 2005.

TINLAND, F. Interactions, réseaux, différenciation. In: PARROCHIA, D. (Org.). Penser les réseaux. Seyssel, FR: Champ Vallon, 2001. p. 245-265.

TOLEDO JR., R. Telecomunicações e uso do território brasileiro. In: SOUZA, M. A. A. (Org.). Território brasileiro: usos e abusos. Campinas, SP: Territorial, 2003. p. 93107.

VELTZ, P. Mundialización, ciudades y territories. Barcelona: Ariel, 1999.

VIRILIO, P. O espaço crítico e as perspectivas do tempo real. Rio de Janeiro: Editora 34, 1993.

WALKER, A. A map of every device in the world that's connected to the internet. GIZMODO, 28 June 2014. Disponível em: <http:/gizmodo.com/a-map-of-everydevice-in-the-world-thats- connected-to-t-1628171291>. Acesso em: 15 abr. 2016.

WHATSAPP. About WhatsApp, 2018. Disponível em: $<$ https://www.whatsapp.com/about/?lang=en>. Acesso em: 21 jul. 2018.

WIENER, N. Cybernétique et societé. Paris: UGE, 1962.

WIKIPÉDIA. Exabyte. Disponível em: <https://pt.wikipedia.org/wiki/Exabyte>. Acesso em: 20 jul. 2016. 